UNIVERSIDADE DE SÃO PAULO

FACULDADE DE FILOSOFIA, LETRAS E CIÊNCIAS HUMANAS DEPARTAMENTO DE LETRAS CLÁSSICAS E VERNÁCULAS ÁREA DE FILOLOGIA E LÍNGUA PORTUGUESA

Ednalvo Apóstolo Campos

\title{
A sintaxe pronominal na variedade afro- indígena de Jurussaca: uma contribuição para o quadro da pronominalização do português falado no Brasil
}

Versão Corrigida 
UNIVERSIDADE DE SÃO PAULO - USP

Faculdade de Filosofia Letras e Ciências Humanas - FFLCH

Departamento de Letras Clássicas e Vernáculas - DLCV

\section{Ednalvo Apóstolo Campos}

Tese apresentada ao Programa de PósGraduação do Departamento de Letras Clássicas e Vernáculas da Faculdade de Filosofia, Letras e Ciências Humanas da Universidade de São Paulo, como requisito parcial para a obtenção do título de Doutor em Filologia e Língua Portuguesa.

Versão Corrigida

De acordo

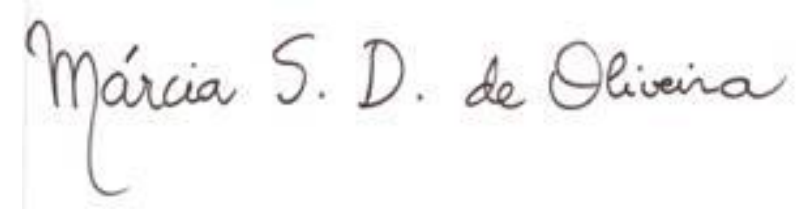

Orientadora: Profa. Dra. Márcia Santos Duarte de Oliveira

Co-orientador: Prof. Dr. Tjerk Hagemeijer

São Paulo

2014 
BANCA EXAMINADORA

\section{Membros Titulares:}

Orientadora: Profa. Dra. Márcia Santos Duarte de Oliveira (DLCV / USP)

Profa. Dra. Charlotte Marie Chambelland Galves (Unicamp)

Prof. Dr. Alan Norman Baxter (UFBA)

Profa. Dra. Margarida Taddoni Petter (DL/USP)

Profa. Dra. Maria Clara Paixão de Souza (DLCV/USP)

Membros Suplentes:

Profa. Dra. Maria Aparecida Ribeiro Torres Moraes (DLCV/USP)

Profa. Dra. Ana Paula Quadros Gomes (UFRJ) 
Agradecimentos

À minha orientadora, Márcia Oliveira, que me abriu as portas da Universidade de São Paulo. Sou-lhe muito grato, pelo estímulo, pelas orientações, por ter me conduzido aos estudos sintáticos, pela amizade e pela parceria acadêmica que construímos ao longo desses anos de doutoramento.

Ao professor Tjerk Hagemeijer co-orientador da pesquisa na Universidade de Lisboa, os meus sinceros agradecimentos.

Agradeço aos professores que aceitaram participar da banca de defesa: Charlotte Galves, Maria Clara Paixão de Souza, Margarida Petter e Alan Baxter e às professoras suplentes, Maria Aparecida Torres Moraes e Ana Paula Quadros.

Às professoras da Universidade de Lisboa, Anabela Gonçalves, Gabriela Matos, Inês Duarte e Ana Maria Martins, por terem me aceito como aluno especial em seus seminários e pelo muito que aprendi sobre português europeu.

À Universidade do Estado do Pará por ter me concedido licença e bolsa de estudos.

À CAPES, pela Bolsa Doutorado Sandwiche durante os doze meses em que estive na Universidade de Lisboa.

Agradeço, sinceramente, a todas as pessoas da comunidade de Jurussaca que sempre me receberam muito bem em todas as vezes que estive lá, às famílias que me abriram suas casas e aceitaram fazer gravações: Seu Valdecir e D. Lucimar, D. Antônia, D. Maria José, Seu Amadeus e D. Umbelina, Seu Manoel e D. Fausta, Seu Genilsson e esposa, Seu Edvaldo e D. Lúcia, Seu Edvaldo da Associação, Seu Chico, D. Benedita in memorian e ainda, especialmente, à D. Vicência, ex-moradora da comunidade, que me recebeu em sua casa em Tracuateua, e, mesmo com a sua idade, cerca de 101 anos, aceitou gravar entrevista.

Aos amigos na USP, pelas parcerias de trabalhos ou apenas pelo contato e amizade, o que não é pouco: Eduardo Santos, Francisco Lopes, Raquel Santos, Jair Cecim, Maria Zanoli e André Rauber.

Aos colegas do Grupo GELIC.

Aos amigos em Lisboa, Irene, Suzana, Vera, Carlos e Mônica.

À amiga Glória Rocha, que me acolheu inicialmente em São Paulo.

Agradeço a Célia Virgolino pela amizade e apoio sempre constante, nesses anos em São Paulo. 
Meus maiores agradecimentos à minha família por todo o apoio, principalmente, os meus pais, Maria de Lourdes e Otávio Campos.

Finalmente, agradeço a Deus, por ter me permito chegar até o final desse trabalho. 


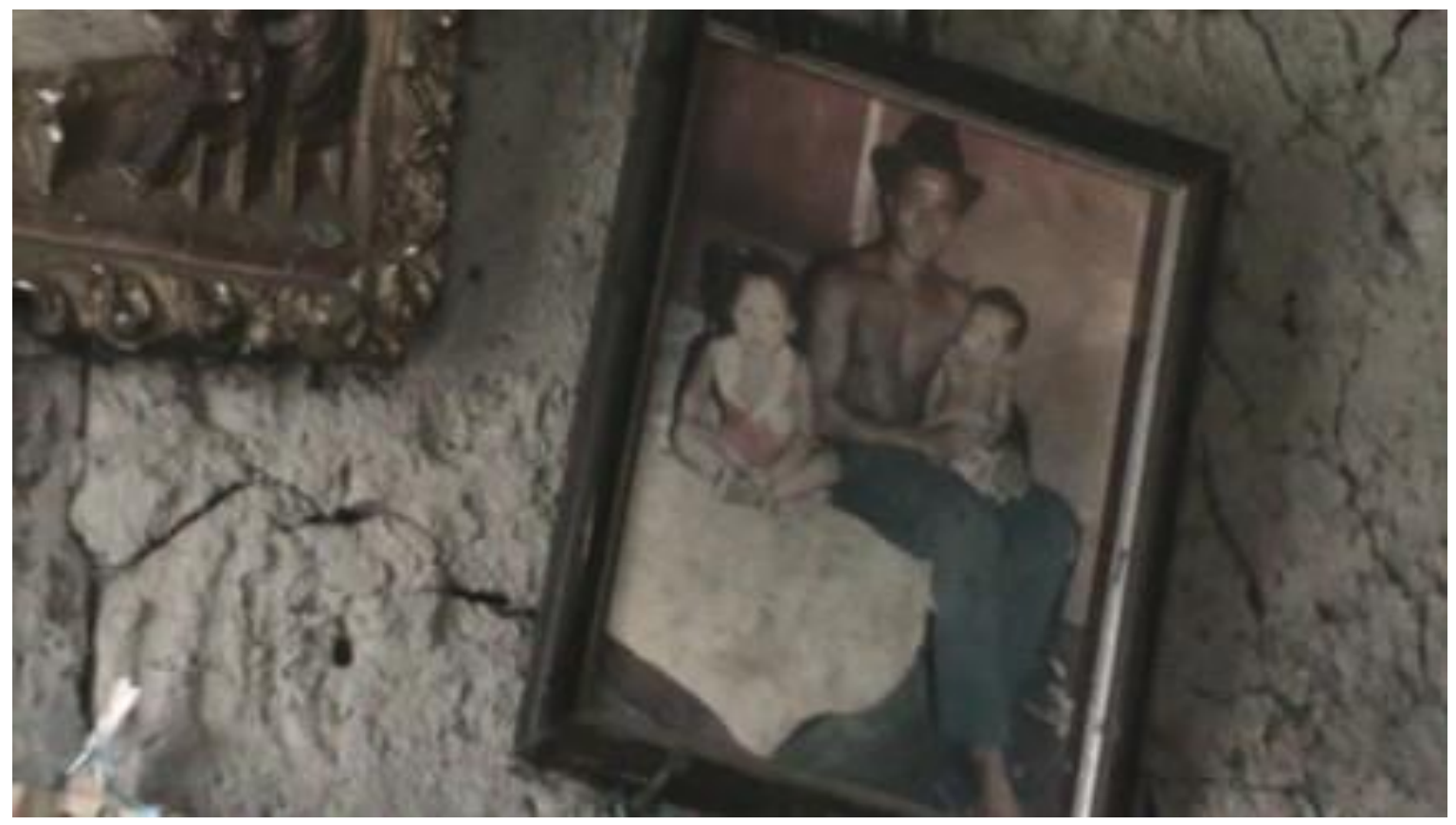

Aos homens e mulheres de Jurussaca que anonimamente constroem esse país. 
Eu acho que essa uma é que num conta mais nada... porque ela tá muito velhinha... (Seu Chico, 75 anos, morador de Jurussaca).

“[...] o estudo do encontro do português com línguas, povos e culturas africanas $e$ indigenas é fundamental para a compreensão do chamado português brasileiro."

(FIORIN \& PETTER, 2008) 


\section{RESUMO}

Esta pesquisa aborda a sintaxe pronominal pessoal da comunidade quilombola de Jurussaca/PA, sob os pressupostos da teoria gerativa, nas versões de Princípios e Parâmetros (Chomsky, 1986) e Minimalista (Chomsky, 1995, 2001). Dentro desse quadro, destacam-se os estudos sobre a categoria pronominal desenvolvidos por Zwicky (1977), Kayne (1975, 1991), Borer (1981), Bonet (1991), Cardinaletti \& Starke (1999), Ewerett (1994), Duarte \& Matos (2000), Duarte, Matos \& Gonçalves (2005), Galves (2001a,b), Galves \& Abaurre (2002), Déchaine \& Wiltchko (2002), entre outros. Parte-se, inicialmente, da expressão do português brasileiro a partir do viés dicotômico existente entre suas variedades: o PB e o PVB. Essa dicotomia tem sido denominda de "polarização sociolinguística do Brasil" (LUCCHESI, 2008, 2009). Assume-se (cf. Oliveira et alii, no prelo) o conceito de Português Afro-indígena, relativo às variedades de português popular faladas no Brasil em comunidades rurais que conservam especificidades etnolinguísticas. Propõe-se que essas variedades "localizam-se" dentro de um continuum de variedades de português brasileiro [+marcadas] (como o português afro-brasileiro e o indígena). Analisa-se, a partir da sóciohistória, e das construções sintáticas da expressão da comunidade: pronomes clíticos e tônicos atemáticos; o pronome de $1^{\mathrm{a}}$. pessoa nós [nวs] em posição pré verbal ou proclítica, entre outras, como parte de fatores sintáticos (e etnolinguísticos) que sugerem uma provável 'reestruração' em certos aspectos da sintaxe pronominal de Jurussaca; apontam para a existência prévia de um forte contato linguístico e são tomados como suporte para as hipóteses assumidas.

Palavras-chave: Português Brasileiro; Português Afro-indígena; Teoria Sintática; Sintaxe Pronominal. 


\begin{abstract}
This research addresses the syntax of the personal pronoun system of the maroon community of Jurussaca/Pa, under the assumptions of generative theory, in its Principles \& Parameters (Chomsky, 1986) and Minimalist (Chomsky, 1995, 2001) versions. Within this theoretical framework, the studies of pronominal category developed by Zwicky (1977), Kayne (1975, 1991), Borer (1981), Bonet (1991), Cardinaletti \& Starke (1999), Ewerett (1994), Duarte \& Matos (2000), Duarte, Matos and Gonçalves (2005), Galves (2001a, b) Galves \& Abaurre (2002) Dechaine \& Wiltchko (2002), among others, are highlited. The study departs from a consideration of the bias in dichotomy existing between the varieties known as Brazilian Portuguese (BP) and Brazilian Vernacular Portuguese (BVP). This dichotomy has been refered to as the "sociolinguistics polarization of Brazil" (LUCCHESI, 2008, 2009). The study assumes the classification Afro-Indigenous Portuguese (cf. Oliveira at al, in press) in relation to to the popular varieties of Portuguese spoken in Brazilian rural communities that preserve ethno-linguistic specificities. It is then proposed that these varieties are located on a continuum of [+ marked] Brazilian Portuguese varieties (such as Afro-Brazilian and Indigenous Portuguese). As from the socio-history of the community it is analyzed syntactic constructions with clitic pronouns and athematic tonic pronouns devoid of thematic role; the 1st person pronoun 'nós' [nวs] - (we) - in the pre-verbal or proclitic positions, among others, are syntactic constructions that suggest 'grammatical restructuring' and point to the prior existence of a strong language contact and are taken as support for the hypotheses here assumed.
\end{abstract}

Keywords: Brazilian Portuguese; Afro-indigenous Portuguese; Syntactic Theory; Pronominal Syntax 


\section{Lista de Figuras, Quadros e Mapas}

Figura 1 - Distribuição dos escravos africanos no Brasil 37

Figura 2 - Continuum dialetal de português brasileiro 58

Figura 3 - Aldeias do tronco Jê 141

Figura 4 - Croqui da subárea Jurussaca

Figura 5 - Croqui da subárea Cebola

Quadro 1 - As formas pronominais da NGB 64

Quadro 2 - As formas pronominais do PB 65

Quadro 3 - Anáforas ligadas 78

Quadro 4 - Pronomes Pessoais (formas fortes) 80

Quadro 5 - Tipologia das categorias lexicais 83

Quadro 6 - Os pronomes clíticos 84

Quadro 7 - Padrões rítmicos dos enunciados 104

Quadro 8 - Colocação pronominal proclítica 104

Quadro 9 - colocação pronominal enclítica 105

Quadro 10 - os pronomes pessoais da norma culta 107

Quadro 11 - Orações principais com próclise 109

Quadro 12 - Projeção para as colocações enclíticas românicas

Quadro 13 - Projeção para as colocações proclíticas românicas

Quadro 14 - projeção de próclise em PB em períodos simples

Quadro 15 - projeção do período composto em PB: próclise/ênclise

Quadro 16 - Pronomes Pessoais Referencias de Jurussaca

Quadro 17 - As Anáforas na Expressão Pronominal de Jurussaca 


\section{Lista de Abreviaturas}

(i) Abreviaturas de Categorias

\section{Português}

AdjP sintagma adjetivo

Agr concordância (I explodido)

AgrSP sintagma concordância sujeito

AgrOP sintagma concordância objeto

ASpP sintagma aspectual

$\mathrm{CP}$ sintagma complementizador

DP sintagma determinante

$\mathrm{D}^{0} \quad$ núcleo de determinante

FP sintagma foco

EP traços de periferia

I/Inflx flexão

IP sintagma flexional

NP sintagma nominal

Neg negação

PP sintagma preposiçional

$\Sigma \quad$ polaridade (sigma)

$\Sigma \mathrm{P} \quad$ sintagma sigma

$\mathrm{S} \quad$ sentença

TP tempo

$v \quad$ verbalizador/verbo leve

$\mathrm{V}$ verbo lexical

$\mathrm{V}_{\text {inf }} \quad$ verbo infinitivo

VP sintagma verbal

WP sintagma posição Wackernagel

$\mathrm{X}^{0} \quad$ núcleo

X’ nível intermediário

XP sintagma (projeção máxima)

\section{English}

adjective phrase

agreement (split I)

subject agree phrase

object agree phrase

aspectual phrase

complementizer phrase

determiner phrase

determiner head

focus phrase

edge features

inflection

inflectional pharse

noun phrase

negation

prepositional phrase

polarity (sigma)

sigma phrase

sentence

tense

verbalizer/light verb

lexical verb

infinitive verb

verbal phrase

Wackernagel position phrase

head

intermediate level

phrase (maximal projection) 


\section{(ii) Abreviaturas de palavras/expressões}

\section{Português}

$\mathrm{Cl} \quad$ clítico

ClPrn clítico pronominal

CV categoria vazia

C-comando comando categorial

EPP princípio de projeção estendida

FOC focalização

Num número

O objeto

Op operador

PB português brasileiro

$\mathrm{PCl}$ português clássico

$\mathrm{PE} \quad$ português europeu (moderno)

P\&P princípios e parâmetros

$\mathrm{PPh}$ sintagma fonológico

Pers pessoa

S sujeito

TRL teoria de regência e ligação

\section{English}

clitic

pronominal clitic

empty category

categorial command

extended projection principle

focalization

number

object

operator

Brazilian Portuguese

classical portuguese

(modern) European Portuguese

principles and parameters

phonological phrase

person

subject

government and binding theory 


\section{Lista de Símbolos}

Português

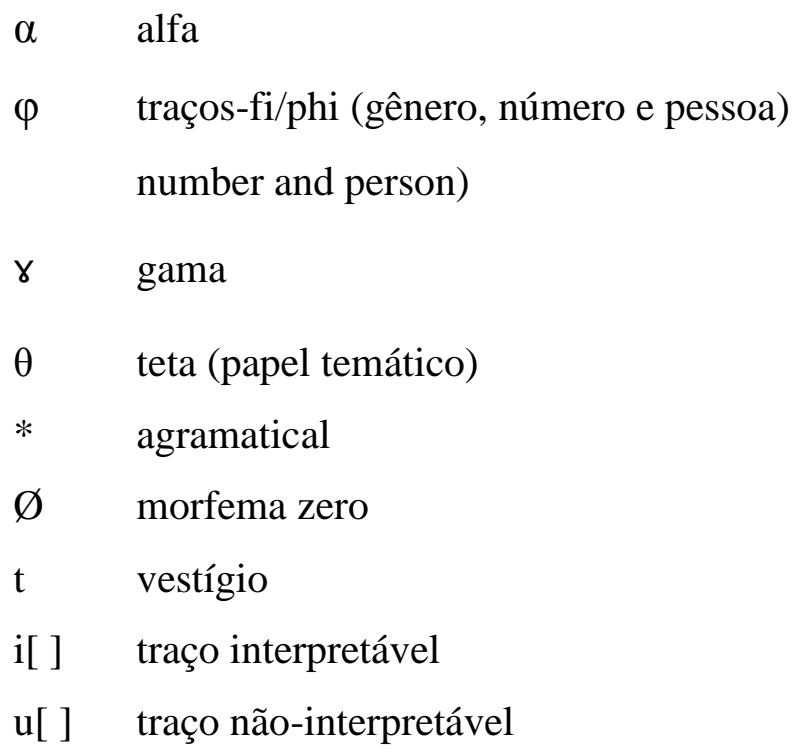

\section{English}

alfa

phi-features (gender,

gama

teta role

ungrammatical

zero morpheme

trace

interpretable feature

uninterpretable feature 


\section{SUMÁRIO}

Introdução

CAPÍTULO I - O continuum de português: buscando uma definição do português brasileiro

1.1. Introdução

1.2. O Português Brasileiro: das motivações históricas

1.3. Da generalização do PB nos quadros teóricos da linguística brasileira: a gênese da pseudo-homogeneidade

1.4. Das especificidades do PB ou da desconstrução da pseudo-homogeneidade: em busca de um continuum de português

1.4.1. Sobre a história do continuum de português 52

1.4.2. Uma proposta de continuum para o português de Jurussaca

1.5. O Português Afro-Indígena

1.6. Considerações sobre o contato entre línguas 59

1.7. Síntese do capítulo 61

CAPÍTULO II - O estatuto das formas pronominais tônicas e clíticas - abordagens clássica e formal $\quad 62$

2.1. Introdução

2.2. Noções iniciais das categorias pronominais 64

2.3. O estatuto pronominal e a Teoria de Regência e Ligação 68

2.3.1. O conceito de Ligação, o estatuto pronominal e a noção de C-comando 72

2.3.2. As anáforas 76

2.3.3. Os pronomes $\quad 79$

2.3.4. As expressões- $R$

2.4. O pronome clítico 83

2.4.1. Clíticos simples e especiais 88

2.4.2. Diferenças estruturais clíticas nas línguas românicas 90

2.4.3. Possibilidades de análises clíticas: algumas propostas vigentes na

Literatura 93

2.4.3.1. Propostas voltadas ao estatuto sintático 95

2.4.3.2. Propostas referentes ao estatuto morfológico 98 
2.4.3.3. As propostas voltadas ao estatuto fonológico

2.4.4. As construções com pronominais clíticos em português 108

2.4.4.1. A subida de clítico 113

2.4.4.2. A interpolação clítica 117

2.4.4.3. Os grupos clíticos 118

2.4.4.4. Projeções estruturais de ênclise e próclise em PE 119

2.4.4.5. Projeções estruturais de ênclise e próclise em PB 127

2.5. Da existência de pronome fraco em PB 132

2.6. Síntese do capítulo 133

Capítulo III - Para uma análise da expressão pronominal do português afro-indígena de Jurussaca $\quad 135$

3.1. Introdução 136

3.2. Apresentação da comunidade 136

3.2.1. A comunidade de Jurussaca: aspectos sócio-históricos 136

3.2.2. Sobre a constituição étnica de Jurussaca 140

3.3. Metodologia, construção e organização dos corpora da pesquisa 145

3.4. Análise dos corpora 146

3.4.1. As primeiras análises $\quad 147$

3.4.2. O paradigma Sujeito 151

3.4.3. O paradigma Complemento Direto 158

3.4.4. O paradigma Complemento Indireto 161

3.4.5. O paradigma Oblíquo 163

3.4.6. As Anáforas 164

3.4.7. O estatuto dos pronomes atemáticos e/ou inerentes 166

3.4.7.1. O clítico inerente se 166

$\begin{array}{ll}\text { 3.4.7.2. O clítico sujeito } & 168\end{array}$

3.4.7.3. O estatuto morfossintático do pronome lhe em construções

$\begin{array}{ll}\text { atemáticas } & 168\end{array}$

3.4.7.4. O estatuto dos pronomes atemáticos eu / ele 170

3.4.8. O estatuto do pronome nós [nวs] sua colocação pré-verbal 172

3.4.9. As pro-formas pronominais esse/aquele um-essa/aquela uma 176

$\begin{array}{ll}\text { 3.5. Síntese do capítulo } & 177\end{array}$ 
4. Conclusão

5. Bibliografia

186 


\section{Introdução}

Esta tese está focada na sintaxe pronominal pessoal da comunidade quilombola de Jurussaca/PA. Mas, para além da expressão pronominal, dados os contornos subjacentes ao tema, outros objetivos se fizeram presentes. Primeiramente, as considerações sobre a variedade de português falada na comunidade relativamente ao PB. Em segundo lugar, as questões sócio-históricas que envolvem comunidades como Jurussaca; o traço étnico, as relações de contato, etc. Em terceiro lugar e, a partir de motivações empíricas, ainda se fazia necessário postular um locus, para a variedade de Jurussaca, dentro do quadro das variedades vernaculares de português - vem daí a ratificação de um continuum de português, já postulado para as variedades de PB e PVB.

Mas antes de prosseguir nos objetivos da tese, acho de bom tom apresentar Jurrussaca:

\section{A comunidade de Jurussca - palavras iniciais}

A expressão pronominal de Jurussaca, foi para mim, desde o início, um dos traços que melhor assinalam a sua 'identidade', por assim dizer, a sua 'maneira muito particular de usar a língua', seja na interação cotidiana entre eles mesmos ou entre eles e os de fora situações bem marcadas pelo traço formal versus informal -; seja no uso das formas referenciais, de expressões com valor de pro-forma pronominal, do pronome resumptivo, do duplo se (anafórico e inerente - 'ele se mudou-se pra cá'), das construções com clíticos e tônicos atemáticos etc.

Jurussaca é composta por pessoas simples, humildes, carentes, descendentes de povos africanos, de povos indígenas. É, na verdade, mais uma comunidade composta por brasileiros pobres, trabalhadores, que pelejam nos seus "roçados" na lida com a mandioca, o feijão e o milho... Portanto, abordar a sua expressão pronominal, numa pesquisa acadêmica, pode parecer um tanto leniente, um ato de desengajamento social, frente a tantas demandas que as pessoas de Jurussaca têm.

Gostaria de contribuir diretamente com a redução de suas demandas mais urgentes, mas como professor e linguista cabe a mim estudar aquilo que, do meu ponto de vista, traduz a maior riqueza que eles têm - sua língua -, sua herança cultural e linguística herdada de seus antepassados, tão bonita de ouvir: pelo ritmo e entonação particulares, por certos aspectos morfológicos, pela sintaxe... Sempre despertam o meu encantamento! Quisera eu, por meio de construções causativas com 'fazer', fazer surgir o pronto socorro, o sistema de 
distribuição de água, a biblioteca na escola, se é que precisam de uma... Penso que sim! E tantas outras demandas... Mas o sorriso e a alegria não carecem da mágica do 'fazer surgir' pois já estão cotidianamente lá, fazem parte deles, e se traduzem nos festivais, nos festejos, no colorido de suas roupas para dançar o retumbão, a mazurca e a marujada bragantina, tradições das festas de São Benedito, presentes também ali em Jurussaca. Como professor e linguista, infelizmente, não tenho tais dons nem são precisos, pois aprendi muito mais ali com "essa uma" e "com esses um" do que na vasta bibliografia que persegui nesses anos de esudos.

\section{Voltando aos objetivos da pesquisa e ao quadro teórico geral}

Neste trabalho assumo os pressupostos da teoria gerativa, dentro das versões Minimalista (Chomsky, 1995, 2001) e de Princípios e Parâmetros (Chomsky, 1986). Dentro desse quadro, destacam-se os estudos sobre a cateria pronominal desenvolvidos por Zwicky (1977), Kayne (1975, 1991), Borer (1981), Bonet (1991), Cardinaletti \& Starke (1999), Ewerett (1994), Duarte \& Matos (2000), Duarte, Matos \& Gonçalves (2005) Galves (2001a,b), Galves \& Abaurre (2002), Déchaine \& Wiltchko (2002), entre outros.

Uma das principais motivações para a pesquisa que deu origem a esta tese foi a busca por uma compreensão maior de fenômenos que estão relacionados à colocação pronominal, descortinando daí um universo a ser explorado e um rico campo bibliográfico já com estudos bastante diversificados. É um tema fascinante, pois à primeira vista parece que tudo já foi dito sobre o quadro pronominal no português e nas línguas românicas, como um todo. Na verdade, há sempre possibilidades de análises diferentes a partir de pontos de vista diferentes e abordagens teóricas também diferentes. No caso desta tese não trago novidades no sentido de uma abordagem nova; ao contrário, são percursos já trilhados por muitos linguistas, mas talvez tenha sido revolucionário, sim, para mim, pois possibilitou-me a entrada em um universo cheio de possibilidades e propostas interessantíssimas de análise da categoria pronome nas língua do mundo em que passei a conhecer mais de perto uma literatura com descrições cheias de possibilidades de abordagens ainda desconhecidas por $\operatorname{mim}$.

Logo no meu primeiro contato com a comunidade de Jurussaca, chamou a minha atenção construções sintáticas como: "Ele nós ajudou”. Achei-a intrigante por dois motivos: normalmente estas comunidades não têm em seus registros o pronome clítico de primeira pessoa do plural 'nos' - cuja colocação em próclise ao verbo é a preferencial em português 
brasileiro -; mas não me parecia, à primeira vista, ser um clítico, mas um pronome tônico. Por outro lado, os pronomes complementos tônicos são comuns ao português vernacular brasileiro, com colocação obrigatoriamente pós verbal: "Ele ajudou nós"; aliás o padrão no português vernacular e até certo porto 'normal' ou aceitável no português brasileiro falado e tido como culto. Começava aí um interesse particular em relação àquela possibilidade de colocação pronominal ainda desconhecida para mim, com duas possibilidade de tratamento: (i) se fosse um clítico estaria no lugar certo, no entanto, construções com complementos clíticos são incomuns nessas variedades; (ii) se fosse mesmo um tônico, estaria em um ambiente pouco comum aos pronomes tônicos complemento, realizados no português brasileiro.

Além do mais, naquela comunidade, era muito interessante a utilização de pronomes pessoais, principalmente, os de tratamento, em ocorrência nas situações de interação que eu presenciei ali; o tratamento sempre muito respeitoso, principalmente pelos mais velhos, ao dirigirem-se a mim, revelando, por vezes, um distanciamento com a forma 'sinhô' e 'você', sempre utilizada comigo, mas entre eles o 'tu' sempre presente, deixando transparecer aspectos socioculturais muito típicos da comunidade e que contrastavam com as cidades vizinhas, Bragança e Tracuateua cujo grau de formalidade era bem menor nas interações comunicativas com as pessoas da cidade.

Assim, com base nos estudos que apontei anteriormente, muitos dentro de abordagens funcionalistas e outros gerativistas, o passo seguinte, quanto à escolha da abordagem teórica seria importante, pois por trás da minha intenção em descrever e analisar a expressão pronominal da comunidade e proceder a realização de cotejo com outras variedades, interessava-me tanto mais a compreensão do status da categoria pronominal de forma mais precisa, e as postulações teóricas que me pareceram mais apropriadas foram as propostas dentro do quadro da gramática gerativa.

No quadro da teoria gerativa há várias propostas e possibilidades de análises da categoria pronominal sob vários aspectos em várias línguas do mundo, além da já clássica definição de pronomes como um composto de traços-phi no quadro teórico de Regência e Ligação (Chomsky, 1981) e na Teoria de Princípios \& Parâmetros (Chomsky, 1986), a partir das noções de $c$-comando e dos princípios $A, B$, e $C$ que definem as categorias nominais, assim como as noções de categoria vazia pro (prozinho) e $P R O$ (prozão), tão importantes para aquele momento da teoria. A noção de c-comando, aliás é um postulado que se mantém até os dias de hoje, mesmo com a revisão teórica proposta no Programa Minimalista. 
Kayne (1991), em um texto clássico sobre pronome, propôs que os pronomes lexicais, tal qual os nomes, são sintagmas NPs ou DPs completos e ocupam posições de base na sentença, enquanto pronomes clíticos não comportam todas as camadas dos lexicais (razões ligadas a questões não apenas fonológica mas também referenciais) e, por isso, ocupam posições derivadas. Mas os pronominais clíticos entrariam já na numeração da sentença como próclises ou ênclises ou seriam derivados como SNs simples e depois movidos numa operação de movimento? Outras propostas de análise como a tripartição pronominal de Cardinaletti \& Starke (1999) com os quadros de restrição sintática são propostas que também serão mencionadas.

Os corpora que compuseram a pesquisa foram: (i) o corpus do acervo do Projeto IPHAN/USP, com mais de 10 horas de gravações com moradores da comunidade, e cerca de 15 horas de gravações obtidas em duas rádios em Bragança: Fundação Educadora de Comunicação de Bragança/PA e Rádio Pérola FM, contendo entrevistas, conversas ao vivo, etc.; (ii) 3 a 4 horas de gravações com moradores das cidades de Bragança e Tracuateua; (iii) cerca de duas horas de gravações feitas com moradores de Jurussaca na última visita que fiz à comunidade, em julho/2012.

\section{O português brasileiro}

Os termos PB (português brasileiro) e PVB (português vernacular brasileiro) são comprendidos no trabalho como variedades [+/- marcadas] no continuum de português brasileiro que proponho nesta tese. A consolidação do termo PB no ambiente acadêmico brasileiro estendeu-se ao máximo, dando-lhe um enfoque 'metalinguístico', representativo da fala dos brasileiros. Mas alguns ecos dessa extensão do PB não foram resolvidos. Por exemplo, essa extensão de sentido da expressão PB pode, de fato, ser representante da escrita e da fala dos brasileiros? Talvez, para o português escrito essa asserção seja, em parte, verdadeira, no entanto, é importante lembrar que as gramáticas publicadas recentemente (como as de Castilho (2010), Perini (2010) e Bagno (2011)) servem como contra-argumento a esse questionamento, pois nelas, muitas prescrições de usos considerados 'errados' passam a ser 'aceitos' ou ganham status já que são contemplados em gramáticas que descrevem a fala dos brasileiros. Há muitas questões a se considerar e, muitas delas, a sociolinguística têm lançado luzes. O parâmetro escolaridade é tomado como a 'fronteira' que delimita o PB, variedade culta, falada por pessoas com formação universitária (noção presente nas bases do projeto NURC). Nesse sentido, a expressão PB é fortemente extensiva pois alcança uma 
extensa generalização ao mesmo tempo que 'convive' ao seu lado uma outra variedade de português vernacular ou popular - o PVB.

Embora as questões relativas à terminologia envolta à sigla PB (português brasileiro) não sejam nenhuma novidade entre os linguistas e sua abrangência e dicotomia face às demais variedades de português já tenham sido também bastante discutidas, acho que ainda é pertinente retomar o conceito de PB. Faço isso no capítulo 1 e justifico as razões para isto: Primeiramente, porque a variedade de língua analisada nos corpora que compõem este estudo não encontra abrigo dentro da sigla $\mathrm{PB}$, relativamente ao quesito variedade falada por pessoas com maior escolaridade, nem dentro da sigla PVB, grosso modo, variedade popular, falada por pessoas com escolaridade baixa, nas áreas rurais ou nas periferias das cidades etc. A complexidade da comunidade onde este estudo foi realizado, por questões sociais e geográficas, enquandra-se dentro da sigla PVB, mas também difere-se dela por questões de etnicidade, tanto afro quanto indígena. Os moradores de Jurussaca são visivelmente miscigenados entre índios e ancestrais de matriz africana. São, aliás, constantes nos relatos dos mais velhos revelações como "minha vó era índia”, a comprovar a miscigenação. Em segundo lugar, a generalização que se estendeu à sigla PB como representante do português falado no Brasil face ao que é falado nos demais países de língua portuguesa, é tratada também como um dos motivos para se repensar o conceito de PB como unidade monolítica, advinda do português antigo, com certas modificações, como é tradicionalmente visto, para uma concepção de PB como resultado de um processo de contato entre línguas. Há pouquíssimos anos o Brasil aprovou a Lei INDL (em 2010), Decreto Lei que reconhece as variedades de imigrantes, dos povos transplantados e dos indígenas, enfim, das minorias linguísticas que são faladas no país, como oficiais. Tal medida corrobora a emergência de 'reanálise' do conceito PB ou de como a concepção de PB foi delineada, quer dizer, a concepção de PB precisa avançar no sentido de ultrapassar a tradicional dicotomia (variedade brasileira e variedade portuguesa) que lhe configurou teoricamente, e incorporar um paradigma baseado numa relação de contato linguístico em todas as fases com que a língua portuguesa, inicialmente, clássica (Português Clássico), e depois a variedade falada no Brasil, se relacionou.

\section{Organização da tese}

No capítulo 1, procurei analisar, reanalisar, discutir, propor e hipotetizar os ganhos, as perdas, enfim as causas e possíveis consequências relacionadas à caracterização do 
conceito Português Brasileiro, no sentido de contribuir um pouco mais com as discussões tão profícuas e importantes desse conceito para a linguística brasileira. Pronho, seguindo Oliveira et alii (no prelo), que a variedade de Jurussaca seja um tipo de variedade afroindígena de português, dadas as especificidades etnolinguísticas ali existentes, e proponho, com base no continuum dialetal de português vigente na literatura, que o PAfro-indJ (Português Afro-indígena de Jurussaca) divide o locus no extremo esquerdo do continuum com as variedades afro-brasileira e indígena, constituindo, essas três, as variedades [+marcadas], ao lado dos falares urbanos [- marcados] e do PB, variedade [não-marcada].

No Capítulo 2, apresento resenhas sobre a tipologia dos pronominais e seu estatuto categorial nas línguas românicas, de modo geral, e as diferenças na colocação pronominal do português europeu e brasileiro. Nesse capítulo, abordo o estatuto pronominal a partir dos enfoques clássico e formal, e os estudos sociolinguísticos que enfocam o PVB. Um segundo ojetivo do capítulo é inserir o objeto da pesquisa nas discussões dentro de hipóteses recentes referentes às origens do Português Brasileiro. A motivação para isso é o fato de se ter como objeto de análise corpora oriundos de uma comunidade quilombola (Jurussaca) e de outras comunidades não quilombolas, ao seu entorno, no caso, as cidades de Tracuateua e Bragança. As discussões que norteiam esse segundo aspecto teórico da pesquisa não estão ligadas a um quadro teórico único, mas a hipóteses que podem ter interesse tanto dentro do quadro teórico da gramática gerativa, quanto dos estudos sociolinguísticos.

No terceiro capítulo, analiso a sintaxe pronominal de Jurussaca a partir dos paradigmas dos casos nominativo, acusativo, dativo e oblíquo; apresento um quadro das proformas pronominais e anafóricas e as ocorrências de clíticos e pronomes tônicos atemáticos. Essas análises são tomadas como parte de um conjunto de fatores linguísticos que, aliados a fatores também sócio-históricos, podem dar suporte à hipotese de que a variedade falada em Jurussaca é do tipo afro-indígena e não apenas afro-brasileira.

Na seção dedicada à conclusão, retomo algumas questões levantadas no decorrer do texto, sobre a provável 'reestruturação' em certos aspectos da sintaxe pronominal da variedade de Jurussaca. Por trás dessa hipóstese, está a configuração sintática de certas construções pronominais, algumas próprias da variedade da comunidade, outras da expressão regional. 


\section{A P Í T U L O I}

O continuum de português: buscando uma definição do português brasileiro

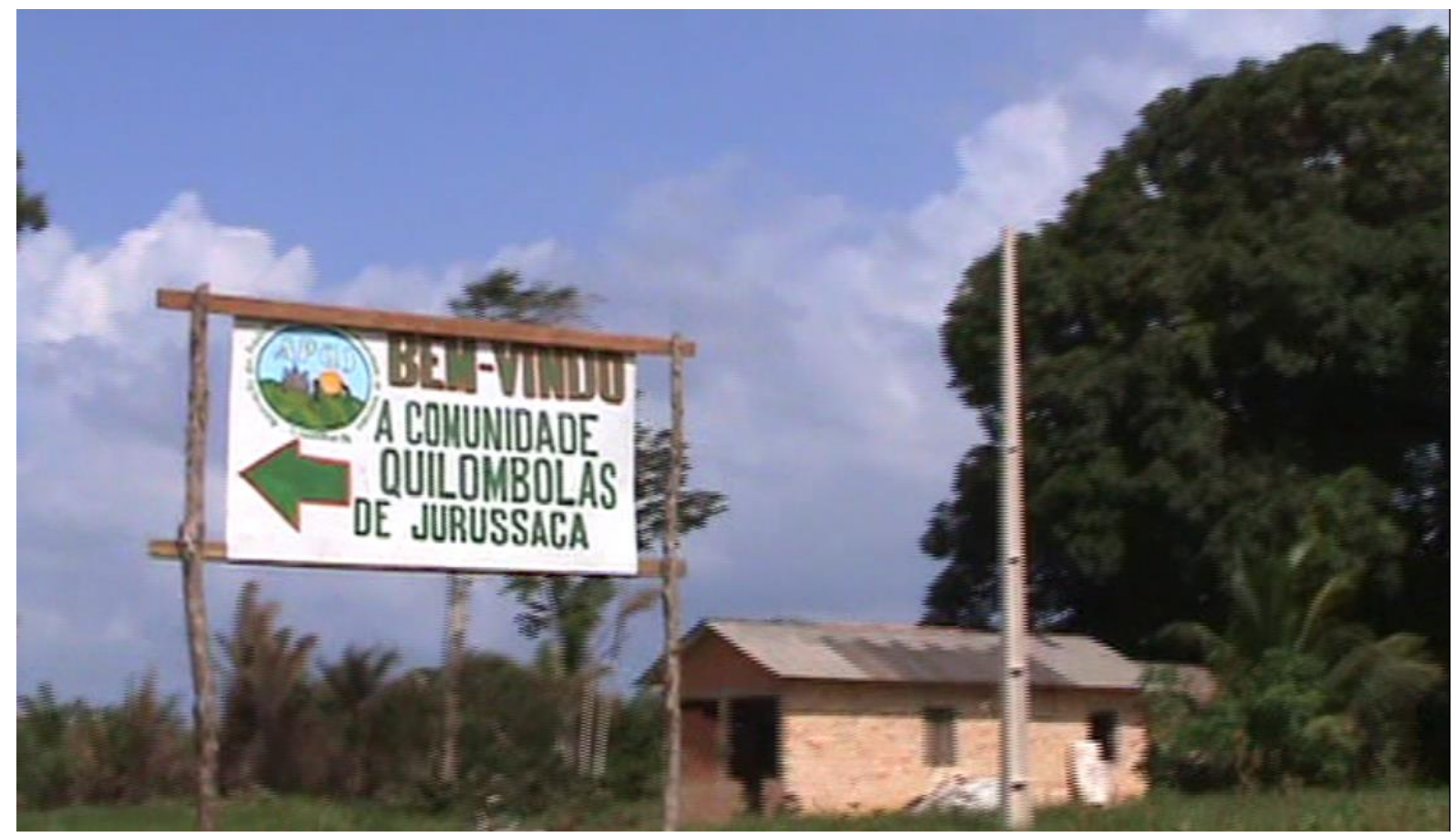




\section{Introdução}

Neste capítulo abordo a expressão do português brasileiro a partir do viés dicotômico existente entre suas variedades, amplamente mencionado na literatura sociolinguística brasileira como um fenômeno de diglossia ${ }^{1}$. Esse fenômeno tem também sido referido como "polarização sociolinguística do Brasil” (LUCCHESI, 2008, 2009) relativamente aos processos de variação e mudança que têm afetado o português falado no Brasil ao longo de sua história ${ }^{2}$. Quer sobre a abordagem de diglossia, quer de polarização sociolinguística, há nesse fenômeno uma relação assimétrica e conflituosa, estabelecida entre a variedade dominante e a(s) dominada(s). Nesse ambiente estão descritas a complexidade e a diversidade de cenários linguísticos que compõem o processo de colonização do Brasil a partir do século XVI, cuja "polarização" da língua ocorre face à divisão linguística do país entre uma variedade culta, historicamente falada pela elite, e o português alterado falado por negros, índios e mestiços. Portanto, esses fatores sociolinguísticos da realidade brasileira dicotomizam a língua portuguesa falada no país em duas vertentes: de um lado o português brasileiro falado, aproximado do standard escrito (PB) e de, outro, o português popular ou vernacular (PVB) em suas múltiplas faces.

Sobre o português falado pela elite, no entanto, vale aqui uma reflexão, pois talvez também tenha múltiplas faces assim como o PVB, com variações conforme as diferentes situações de uso, como adverte Holm (2009):

educated Brazilians are comparable to educated African Americans, who use the standard in writing and speaking in formal situations but often use the non-standard in other social situations to signal intimacy or solidarity [...]. It is often not clear which variety is a speaker's first or dominant language. $[\ldots]$

(HOLM, 2009, p. 101)3.

\footnotetext{
${ }^{1}$ O conceito de diglossia (Ferguson, 1974) baseia-se no termo francês diglossie, para designar certa situação linguística em que duas variantes de uma língua coexistem numa mesma comunidade, cada uma desempenhando um papel definido em que uma das variedades tem uso predominantemente oral em contextos familiar e informal, enquanto a outra caracteriza-se pela aprendizagem formal e uso literário. No entanto, quando se pensa em diglossia, há a visão de que uma variedade de língua é superior à(s) outra(s), emergindo normalmente situações de conflito. Estudos mais recentes têm ampliado o conceito de diglossia face aos de multilinguismo ou plurilinguismo (sobre multilinguismo, ver Rodrigues, 2006).

${ }^{2}$ Além da variedade popular do português brasileiro, há também outras línguas minoritárias que compõem a diversidade linguística brasileira.

${ }^{3}$ Tradução aproximada: "Os brasileiros escolarizados são comparáveis aos americanos negros escolarizados (African Americans) que usam uma norma padrão na escrita e na fala em situações formais, mas frequentemente usam a norma não-padrão em outras situações para marcarem intimidade ou solidariedade [...]. E não é claro qual variedade usada é a primeira língua ou a língua dominante do falante. [...]”
} 
As variedades PB e PVB terão um papel importante quanto à afirmação de um português brasileiro em oposição ao português falado em Portugal (PE). O desenvolvimento dessa temática se dá nas Universidades, principalmente, nos últimos anos do século $\mathrm{XX}$, inicialmente dentro do quadro dos estudos sociolinguísticos de cunho variacionista e, em seguida, o estatuto da sigla PB se torna também objeto de pesquisa no quadro das abordagens gerativistas, seguindo os pressupostos teóricos que possibilitaram a sua generalização no sentido das 'evidências positivas', para utilizar uma expressão técnica relacionada à aquisição de línguas. ${ }^{4}$ Assim, chega-se à compreensão que se tem hoje face ao estatuto do PB no quadro da gramática gerativa. Esse percurso empreendeu uma série de estudos de descrição e cotejo das variedades portuguesa e brasileira e, face aos resultados desses estudos, os pesquisadores ligados à teoria gerativa encontraram um ambiente favorável às postulações de universais de gramática que poderiam apontar se as referidas variedades já haviam desenvolvido o status de gramáticas distintas, dando lugar a uma variedade genuinamente brasileira de português ou português brasileiro $5 / 6$.

De tudo isso, nasciam os pressupostos que iriam identificar a generalização do termo PB existente nos dias atuais e, normalmente, utilizada como representante da variedade de português falada no Brasil, face às faladas em Portugal e demais países de língua portuguesa. No entanto, é importante frisar que, mesmo no Brasil, não é desejável que a sigla PB seja universal. Aliás, a sigla PB é ambígua pois tanto pode representar o português brasileiro standard da modalidade escrita formal ou menos formal (com variação relativamente ao PE escrito), quanto pode, também, querer representar a variedade falada pelos brasileiros, também identificada na literatura como PVB (Português Vernacular Brasileiro, ver subseções 1.4.1 e 1.4.2). Portanto, ao se falar de PB, é sempre importante definir de que PB se fala.

\footnotetext{
${ }^{4}$ Chomsky (2002, p. 34 [2000]) postula que no estágio inicial de aquisição da linguagem o que a criança sabe sobre sua língua vai muito além dos dados a que ela é exposta (input), pois a sua competência linguística, inclui noções que não são óbvias e não são ensinadas diretamente - essa seria uma 'evidência positiva'. Por outro lado, esse estágio inicial é também marcado por 'evidências negativas', ou seja, a ausência de informações explícitas sobre as frases que seriam agramaticais. No input recebido pelas crianças não estariam presentes as 'evidências negativas', mas apenas 'evidências positivas' na forma de frases (geralmente) gramaticais ouvidas pelas crianças. As pesquisas sobre aquisição da linguagem materna corroboram essa assunção e sugerem que as crianças geralmente não são corrigidas quando produzem uma frase agramatical.

${ }^{5} \mathrm{O}$ conceito de língua do ponto de vista teórico da Gramática Gerativa está centrado em duas acepções: LI (língua Interna) e LE (Língua Externa), (Chomsky, 1986, p. 19-24). A GU, foco do linguista gerativista, faz parte da LI. Não menos importante, mas de natureza externa à Faculdade da Linguagem e fora do escopo de domínio da investigação gerativa está a LE. Assim o sistema ou a gramática de uma língua particular pode ser descrita a partir das operações universais e particulares àquela língua, em termos de Princípios e Parâmetros. Logo, a observação de 'evidências positivas' e 'negativas' levam a deduções e generalizações teóricas que fazem parte do quadro de postulações e tendem a ser bem vistas nessa acepção.

${ }^{6}$ É importante destacar a participação, naquele momento histórico, de linguistas brasileiros, alguns deles já falecidos, como Fernando Tarallo e Rosa Virgínia Mattos e outros em franca produtividade, Mary Kato, Charlotte Galves, Ataliba Castilho, entre muitos outros.
} 
Outro aspecto a ser explorado neste primeiro capítulo é a proposição de alguns estudiosos em se 'olhar' o português brasileiro dentro de um continuum dialetal, primeiramente sob o enfoque variacionista e, mais tarde, sob os auspícios do rico processo de contato com as línguas do oeste africano pelo qual o português brasileiro passou ao longo de sua história (cf. BORTONI-RICARDO, 1985; MELLO, 1996: PETTER, 2008; entre outros).

Portanto, os objetivos pretendidos seguem em dois sentidos. Em primeiro lugar, situar o objeto da pesquisa nas discussões dentro de hipóteses recentes referentes às origens do português brasileiro e, em segundo, enfocar a manutenção da proposta do continuum para os estudos em português brasileiro, seguindo as novas tendências baseadas em afirmações a partir das questões do contato linguístico não apenas com as línguas do oeste africano mas também com as línguas autóctones brasileiras. As discussões que nortearão esse segundo aspecto não estão ligadas a um quadro teórico único, mas a hipóteses que podem ter interesse tanto dentro do quadro teórico da gramática gerativa, quanto da sociolinguística ou mesmo de estudos que vêm sendo chamados de etnolinguísticos.

Proponho três características que abarcam as noções da expressão Português Brasileiro e, para facilitar a exposição, apresento-as separadamente: (i) das motivações históricas, (ii) da generalização do $P B$ nos quadros teóricos da linguística brasileira: a gênese da pseudo-homogeneidade e (iii) das especificidades do PB ou da desconstrução da pseudo-homogeneidade: em busca de um continuum de português.

\subsection{O Português Brasileiro: das motivações históricas}

A percepção das marcas do português do Brasil não ocorreu no início da história da colonização, pois é somente a partir do século XVIII que as 'cores tropicais' começam a ser impressas. ${ }^{7}$ Antes disso, porém, os letrados locais (religiosos, alguns comerciantes etc.) seguiam a sintaxe lusitana. Além do mais, a atividade tipográfica não era permitida na colônia (cf. Noll, 2008, p. 167) ${ }^{8}$. As colônias portuguesas na América, aliás, eram duas: a

\footnotetext{
7 As primeiras marcas como as 'cores tropicais' são mencionadas por Pinto (1988 p. 44) com os textos arcadistas.

8 Noll $(2008,167)$ menciona que a política colonial portuguesa não admitia a atividade tipológica, diferentemente do que ocorria nas colônias espanholas, e cita o envio de uma imprensa pelos espanhóis em 1530 ao México. Há, no entanto, relatos de que havia uma intensa atividade tipográfica ilegal no Brail, a exemplo das atividades panfletárias do movimento de insurreição conhecido como Inconfidência Mineira.
} 
colônia do Brasil e a colônia do Grão-Pará e Maranhão, pois consistiam em administrações distintas (cf. Gomes, 1997). ${ }^{9}$

Mas na oralidade, provavelmente, as primeiras variações ocorridas na língua portuguesa falada no Brasil, em comparação à que se falava em Portugal, remonta ao início da colonização com as primeiras gerações de brasileiros filhos dos 'colonos' portugueses, em contato com os indígenas 'domesticados', acentuado com o início do tráfico negreiro, anos mais tarde.

Na verdade, há mais de uma hipótese sobre a história do PB. Aquela que defende o contato como uma das principais causas relacionadas à sua a variação relativamente ao PE é apenas uma das hipóteses sobre a história do PB, baseada no contato. Uma segunda hipótese liga-se à deriva secular e advoga que os traços do português brasileiro contemporâneo já eram atestados no português trazido pela colônia no sec. XVI. Essa hipótese é defendida por linguistas como Anthony Naro e Marta Schere (1993, 2007).

Teyssier (2004 [2001], p. 96) faz alusão ao teatro português do século XVIII e início do século XIX como um exemplo para a identificação de aspectos do português brasileiro, em que algumas peças caracterizam personagens brasileiros a partir de traços fonéticos, sintáticos e também quanto ao uso de formas de tratamento que marcavam a fala dessas personagens, como: mi diga, di lá, sinhorzinho. Pinto (1988 p. 44) também cita o argumento da linguagem do teatro do século XVIII como a melhor fonte para o conhecimento da modalidade oral da língua, propiciando o conhecimento de traços peculiares por meio do discurso direto, do uso dos pronomes de tratamento, de alguns termos pejorativos e de provérbios e ditos populares, como, por exemplo, marcas da oralidade. ${ }^{10}$

Segundo Pinto (1988, p. 28-30), no Brasil setecentista, as atividades culturais eram escassas e ainda seguiam muito de perto as tendências literárias da metrópole. É com o movimento arcadista brasileiro que, segundo Pinto (op. cit., p. 30), ocorre a introdução de 'aspectos de brasilidade' na literatura, perpassando tanto pelo imaginário, com um novo elemento de emoção, com o "nativismo comovido" e "patriotismo particular" e também a retratação de uma nova temática por meio da gente e da natureza americana; quanto pela própria língua, cujo léxico deixa transparecer um mundo 'exótico' de habitantes primitivos e

\footnotetext{
${ }^{9}$ Sobre a constituição do Grão-Pará, transcrevo uma citação de Gomes (1997, p. 41): “O estado do Maranhão e Grão-Pará foi instituído pela Coroa Portuguesa como unidade administrativa, separada do Brasil e ligada diretamente a Lisboa, desde 1621. Até meados do século XVIII, este englobava toda a Amazônia Portuguesa, Ceará e Piauí. Somente ao iniciar a segunda metade do setecentos, as áreas do Maranhão e do Grão Pará seriam separadas em termos de capitanias pela administração colonial.

10 Pinto (1988, p. 44) cita as óperas cômicas atribuídas a Antônio José da Silva - O Judeu (1705-1739) e os dramas, como eram chamados, de Correia Garção - Teatro Novo (1766) e Assembleia ou Partida (1770).
} 
de fauna e flora específicos. Assim, nas palavras de Pinto (op. cit.) "no encanto pelo pitoresco ia transparecendo os vocábulos de origem tupi".

Ainda, segundo Pinto (op. cit.), no século XVIII, além da atualização no léxico, esse processo também atingiu a sintaxe e a morfologia:

Logo à primeira, reconhecemos uma tendência para a simplificação das estruturas frásicas, entendendo-se, por isto, o abandono da frase clássica ou "vernácula", o emprego parcimonioso da ordem inversa e, consequentemente, a busca de uma expressão mais simples e direta do pensamento.

(PINTO, 1988, p. 36)

Como 'sinal' dessa modernização da língua, o autor cita o poema épico Caramuru' no qual diz ser visível a simplificação da frase, a preponderância da ordem direta e a queda de 'tom' (referente à leitura do texto poético), que, nas palavras do autor, deixa de ser declamatório, sem perder a expressividade.

Ainda, no século XVIII, Teyssier (2004 p. 93) aponta os seguintes fatores históricos relacionados ao português do Brasil: (i) o português é falado pelos colonos de origem portuguesa, (ii) as populações de origem indígena, africana ou mestiça aprendem o português, mas manejam-no de forma imperfeita, (iii) ao lado do português existe a língua geral, "um tupi simplificado", gramaticizado pelos jesuítas e tornado uma língua comum. No entanto, a Língua Geral entra em decadência, ainda no século XVIII, com a sua proibição, no âmbito das reformas implementadas pelo Marquês de Pombal, em 3 de maio de $1757 .{ }^{12}$

Mas, é no século XIX que se acentuam as diferenças entre as variantes portuguesa e brasileira com a independência do Brasil, em 1822, e, mais tarde, com a vinda de grandes contingentes de imigrantes europeus, a partir da década de 1870. A literatura desse período tem o léxico marcado por expressões populares, regionalismos, indianismos, africanismos e neologismos, segundo Martins (1988, p. 9), e tem, no movimento literário do romantismo, sua maior expressividade. Teyssier (2004) assinala que é com o Romantismo que a questão da língua realmente se coloca para os escritores, pois, sem romper com o português europeu, eles reivindicavam o direito a uma certa originalidade, procurando uma expressão nova, autêntica e viva, recusando o purismo "mesquinho e estéril" (cf. defendeu-se José de Alencar

\footnotetext{
${ }^{11}$ O poema épico Caramuru relata o descobrimento da Bahia e conta a história de Diogo Álvares Correia, um náufrago português que viveu entre os Tupinambás. Foi escrito pelo Frei José Santa Rita Durão, que nasceu em Minas, em 1722. (MOISÉS, 1995).

${ }^{12}$ A Língua Geral é, na verdade, um conceito ligado à Linguística do Contato. No Brasil, houve: (i) a Língua Geral Paulista, (ii) a Língua Geral Amazônica e (iii) o Guarani Criollo (cf. RODRIGUES, 1996). Argolo (2013) defende a existência da Língua Geral da Bahia.
} 
ao ser acusado de escrever numa língua incorreta por censores portugueses e brasileiros) (Teyssier, op. cit. p. 111).

Passando ao século XX, é nesse período que ocorre o grande movimento de reivindicação do uso de marcas do português oral na literatura, tendência que já vinha das últimas décadas do século XIX, sobretudo com o Romantismo. A literatura tem como um dos expoentes dessa época o escritor Mário de Andrade e é com o movimento de vanguarda do Modernismo, fundado em 1922, que a questão da língua toma um novo vigor. Para Teissyer (2004, p. 112), o Modernismo representa para o Brasil uma mutação cultural e artística fundamental, recusando a tradição e os preconceitos. Ele vai ter expressão em todas as áreas, artística e cultural, e, claro, na literatura. Os modernistas rebelam-se contra a gramática tradicional e querem escrever numa língua que se aproxime da fala brasileira.

Como principal característica da produção literária desse período está o aproveitamento da oralidade. Para Pimentel Pinto (1988, p. 110), a língua literária do Brasil do século XX não só caracteriza uma ruptura em relação à tradição literária luso-brasileira, mas também representa uma tomada de posição relativamente aos valores do século. A oralidade toma vez nesse período; contribuem para sua afirmação o cinema, o rádio, as histórias em quadrinhos e a televisão. A autora dá exemplos referentes ao léxico, à neologia (iniciada no Romantismo por José de Alencar) e a contribuição da oralidade, em Monteiro Lobato, Mário de Andrade, Cassiano Ricardo, Guimarães Rosa, Jorge Amado, Lima Barreto etc. Assim, a 'norma literária' introduzida a partir do Modernismo, com os traços da oralidade na obra dos escritores mais conhecidos, marca a intenção de conferir à variante brasileira de língua portuguesa o estatuto de língua literária. ${ }^{13}$

Com a 'liberdade' alcançada face à vanguarda modernista, as produções escritas pelas novas gerações de escritores brasileiros não mais se confundem com as de um autor português. A 'norma literária brasileira' firmou-se mediante adição de certos traços típicos da oralidade. Os textos midiáticos, de modo geral, também assumem essa nova 'norma brasileira'. No entanto, a prescrição gramatical nem sempre está de acordo com os usos literários e jornalísticos. Por outro lado, não se deve confundir a norma padrão ou língua padrão com a 'norma culta' falada brasileira, em que, por exemplo, o uso da próclise inicial absoluta é categórico face a sua prescrição nas gramáticas normativas.

\footnotetext{
13 O emprego de 'norma literária' não está ligado ao conceito tradicional de norma culta, mas tão somente ao estilo linguístico adotado por muitos escritores brasileiros, a partir do Modernismo, tornando a escrita literária mais próxima da fala dos brasileiros.
} 
A título de exemplo, observemos, a oscilação na colocação pronominal no excerto abaixo, retirado de um texto jornalístico, escrito em português padrão (brasileiro).

(1) Não há outro motivo, aliás, para muitas das atividades a que se dedicam, dedicaramse e dedicar-se-ão quaisquer governantes em qualquer tempo e lugar do mundo: fazer discursos, participar de eventos, comparecer a inaugurações das obras que construíram ou não. ${ }^{14}$

(Folha de São Paulo, Opinião, Editoriais, 03.02.14)

No texto, a colocação pronominal faz uso da próclise, da ênclise e até da mesóclise em um único período, com o mesmo verbo. No entanto, o que parece ser traço de texto 'bem escrito' em norma padrão e de redação elegante, de acordo com a tradição gramatical (baseada na colocação pronominal lusitana), caracteriza, na verdade, um erro de colocação pronominal, pois no português europeu, o padrão de colocação pronominal clítica é a ênclise, e o complementizador 'que' assim como o pivô da oração relativa 'que', no caso do exemplo (1), funcionam como operadores de próclise ou proclizadores (cf. Duarte \& Matos (2000, p. 117, entre outros), tornando a colocação proclítica do pronome 'se' em ocorrências similares às marcadas obrigatória nessa língua, inclusive na fala.

No entanto, a sintaxe do português brasileiro não parece ser sensível à regra de aplicação da próclise - obrigatória - no PE. Aliás, o excerto (1) serve para comprovar exatamente o contrário: o jornalista (profissional familiarizado com a escrita) no afã de contemplar as regras de colocação pronominal, acaba cometendo hipercorreções por conta da pouca familiaridade que tem com a sintaxe pronominal lusitana (prescrita ainda nas gramáticas e em certos manuais).

Um outro exemplo bem interessante diz respeito ao cartaz abaixo, utilizado em uma manifestação de professores (e provavelmente escrito por um deles) em que a categoria reivindicava aumento salarial. Nele, ocorre não somente a colocação pronominal à brasileira, mas também o uso de 'lhe' como pronome acusativo de segunda pessoa já disseminado pela gramática do PB:

\footnotetext{
${ }^{14}$ Essa contrução não é ruim para um brasileiro; soa estranha, no entanto, para os portugueses pois no PE, tratase de contexto obrigatório de próclise.
} 


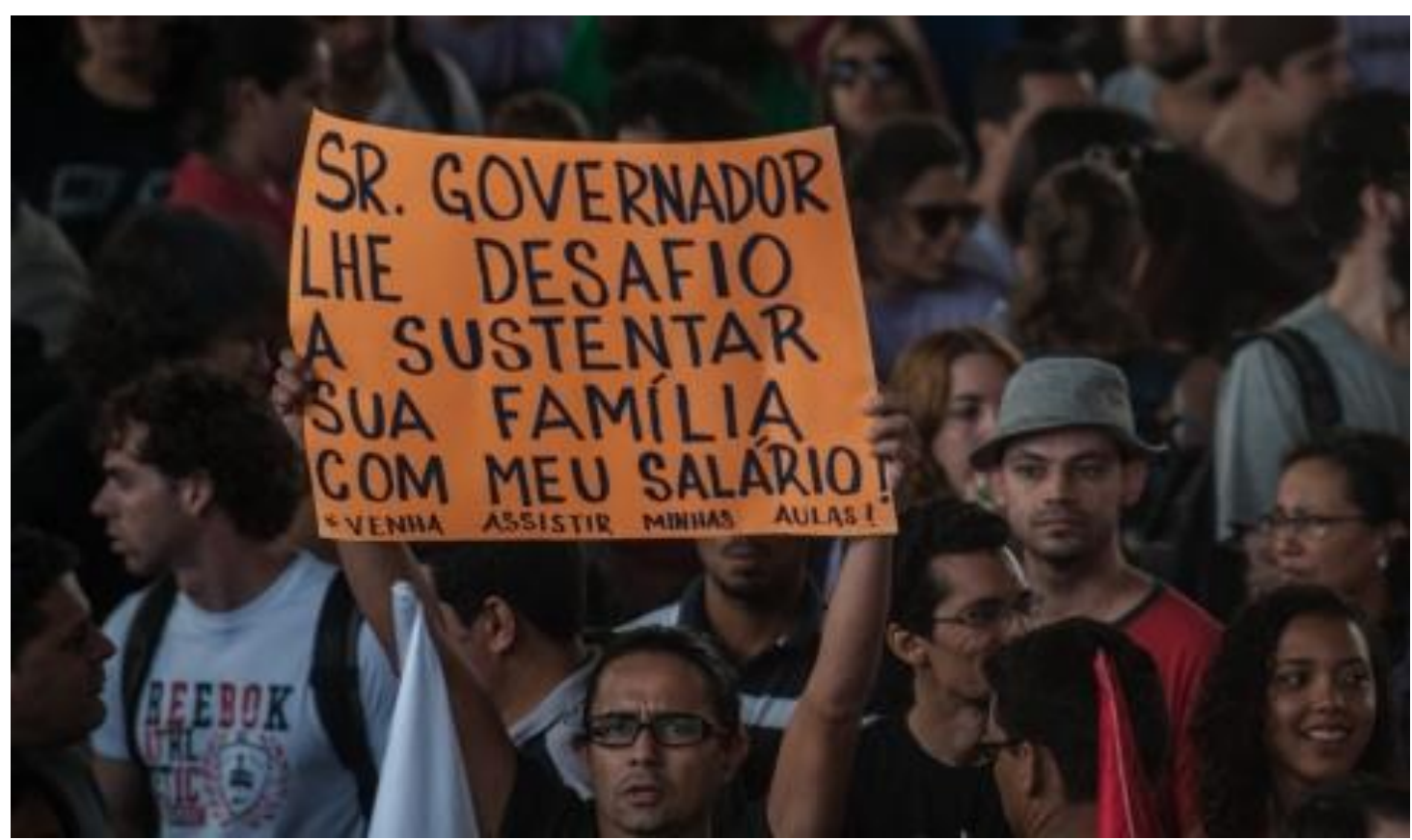

(Professores mantém greve em São Paulo - CAMARGO, 2014).

No capítulo 2, retomo essas questões, mas ainda é válido acrescentar um outro exemplo relativamente à possibilidade de colocação pronominal, pois, em PE, certos advérbios focalizadores/enfatizadores como 'já', 'só', 'até' etc., são operadores de próclise, segundo Costa (2008): ${ }^{15}$

(2) a. O João só $\{$ te telefonou/*telefonou-te $\}$ agora.

b. O João até $\{$ te telefonou/*telefonou-te $\}$.

c. O Rui já $\{m e$ conhece/*conhece-me $\}$.

Por outro lado, certos advérbios de lugar, como 'lá' e 'cá', em PE, tanto podem ocorrer em posições pós-verbais quanto formarem locuções adverbiais com colocações préverbais bastante estranhas para o falante de $\mathrm{PB}:^{16}$

(3) a. Já cá estive/ Já estive cá.

b. Já lá estive/ Já estive lá.

A colocação pronominal, portanto, é um traço que identifica imediatamente o falante brasileiro. Para Pimentel Pinto (1988, p. 32) "a colocação pronominal à brasileira tornou-se ponto fundamental no processo de fixação da nova norma literária".

\footnotetext{
${ }^{15}$ Exemplos retirados de Costa (2008, p. 99, renumerados).

${ }^{16}$ Exemplos retirados de Costa \& Costa (2001, p. 49 e renumerados).
} 
1.3. Da generalização do PB nos quadros teóricos da linguística brasileira: a gênese da pseudo-homogeneidade

Na seção anterior fiz uma breve introdução das questões históricas que motivaram a defesa da incorporação de traços da oralidade na produção escrita no Brasil e, assim, instituindo um português genuinamente brasileiro. Nesta seção, passo à segunda característica que atribuí ao PB na introdução do capítulo, quanto à generalização do termo Português Brasileiro. Antes, porém, menciono o percurso histórico dessa tendência, academicamente. Esse percurso teve seu início nos estudos ligados ao campo da filologia e mais recentemente da linguística.

Noll (2008, p. 174) atribui a Domingos Borges de Barros, o visconde de Pedra Branca, diplomata brasileiro em Paris, a primeira descrição do português brasileiro. Esse estudo foi publicado pelo geógrafo francês Balbi em Introduction à l'atlas ethnographique du globe em (1826), cuja publicação se refere a um tratado sobre o benefício do ensino de línguas e sobre a sua classificação. Noll (op. cit., p. 26) cita também diversas publicações, nos anos que se seguem, de dicionários, glossários e vocabulários brasileiros de língua portuguesa bem como coleções de vocábulos, frases e tratados, com registros de regionalismos que englobavam as mais distintas regiões do país, do Rio Grande do Sul (Collecção de Vocabulos e Frases usados na Província de São Pedro do Rio Grande do Sul) à Amazônia (A linguagem popular Amazonica).

Aos estudos a que se referiu Noll (2008), somam-se, nas décadas seguintes, os estudos da crescente filologia brasileira. Nesse campo destacam-se os nomes de filólogos consagrados, como: Serafim da Silva Neto, Silveira Bueno, Antenor Nascentes, Silvio Elia, Gladstone Chaves de Melo, entre outros. A tradição filológica que cresceu e se instalou nos Cursos de Letras das Universidades do país ao longo do século XX, a partir da década de 60 desse século, no entanto, começa a dar lugar a uma nova tendência iniciada com a inserção, nas Universidades, dos estudos linguísticos, guiada, sobretudo, pelo viés estruturalista. Esses estudos propunham um novo modelo teórico cuja metodologia de investigação primava pelos falares cultos e não cultos, deixando susceptível a tradição clássica sempre fiel à escrita. Um dos precursores dessa tendência foi Câmara Jr. (1970) com suas análises e descrições da estrutura da língua portuguesa a partir da variedade culta falada no Rio de Janeiro. Castilho (2002) explica os fatores que possibilitaram esse novo percurso:

Nos anos 70, registrou-se um empenho pela aplicação de modelos teóricos ao estudo da língua portuguesa. Isto se deveu à criação de veículos 
apropriados para o embate das ideias (fundação da Associação Brasileira de Linguística em 1969), à instalação progressiva dos programas de pósgraduação em linguística e em língua portuguesa em nossas universidades, ao envio de bolsistas para o exterior e à criação de revistas nesta e nas décadas anterior e posterior.

(CASTILHO, 2002, p. 9)

A partir de então, estavam lançadas as bases para importantes projetos de pesquisa que viriam a ser implantados nos anos seguintes em várias instituições.

No entanto, para Castilho (2002), os trabalhos desenvolvidos até aí davam uma visão fragmentária da língua portuguesa, identificando somente problemas de interesse mais imediato para determinadas postulações teóricas e uma série de críticas à gramática tradicional, face aos modelos descritivos possibilitados com abordagens linguísticas. Ainda seria necessária uma visão de conjunto da produção científica brasileira. Mas nesse período ainda havia também muitos debates de resistência 'ao novo' nas Universidades - sobre isso, Castilho (2002, p. 10) comenta: "Num balanço escrito no começo da década, Castilho (1981) identificou uma cisão entre os pesquisadores brasileiros, opondo os "conservadores" aos "receptivos"”.

Merecem destaque alguns projetos coletivos de pesquisa surgidos nessa época, como o Projeto de Estudo da Norma Linguística Culta - NURC - e, mais tarde, o Projeto de Gramática do Português Falado - PGPF. Esses projetos, bastante auspiciosos, tinham metas ambiciosas e mostram dois lados muito interessantes, primeiro porque eles revelam o espírito de união entre os linguistas brasileiros naquele período e também o movimento em prol de mudanças, a intenção de se criar algo novo e de trazer à baila as questões do português brasileiro como língua 'independente'.

Nesse contexto, o português brasileiro assumiu, em vários quadros teóricos, certa independência relativamente ao português europeu. Os pesquisadores ligados à teoria gerativa encontraram ambiente favorável às postulações de universais, o que estava por ser feito em termos de investigação linguística e experimentações empíricas encaixava-se perfeitamente no projeto gerativista. Foram apontadas variações e/ou mudanças significativas na fonologia, na prosódia, na morfologia, e, principalmente, na sintaxe do PB em relação ao PE. No campo da sintaxe, por exemplo, muitas descobertas foram feitas e muitos tópicos entraram para a agenda dos gerativistas (e ainda encontram-se nela), como: $o$ preenchimento do sujeito, o objeto nulo, a ordem marcada da sentença, generalizações quanto a certos usos pronominas (o caso do lhe de segunda pessoa, para citar um exemplo), questões referentes ao complemento acusativo e ao dativo e o uso de complementos 
pronominais tônicos, o tópico e o sujeito, o uso de NPs nus, a temática da agentividade e impessoalidade em construções transitivas, as construções causativas etc., etc., são itens que apontam, de fato, em direção a uma unicidade do português brasileiro.

Essa unicidade vem sendo estendida a outras variedades com estudos de fenômenos similares nelas, como o português falado na África. Sobre as variedades africanas de português, merecem destaque os estudos de Gonçalves (1997, 2010); Gonçalves \& Stroud (1998) e estudos sobre outras variedades africanas de português, sobretudo acerca da concordância de número no sintagma nominal em uma perspectiva da sociolinguística quantitativa - ver, por exemplo, Baxter (2002, 2004, 2011), para o português dos tongas, São Tomé; Figueiredo (2010), para o português reestruturado da comunidade crioula e bilingue (português e santomé) de Almoxarife; Inverno (2005), para o português angolano; Jon-And (2011), para o português caboverdeano e, ainda, Figueiredo \& Oliveira (2013), sobre o português falado em Angola, na região do Libolo, em cotejo com o norte do Brasil.

Voltando ao $\mathrm{PB}$, uma das publicações que marcaram a empreitada de olhá-lo a partir de sua gramática própria, no campo dos estudos gerativistas, destaca-se o livro Português Brasileiro - uma viagem diacrônica, (ROBERTS \& KATO, 1993), em homenagem a Fernando Tarallo. Essa publicação pode ser considerada a consolidação do conceito de PB na área dos estudos gerativistas brasileiros, aliás, para além disso, esse texto marca também um movimento muito forte na linguística brasileira da década de noventa que uniu gerativistas e sociolinguistas numa proposta de pesquisa inovadora, aliando o método utilizado nos estudos variacionistas à teoria gerativa. Essa metodologia ficou conhecida como variação paramétrica ou abordagem paramétrica. Foi idealizada por Mary Kato e Fernando Tarallo em 1989, com a publicação do manifesto "Harmonia trans-sistêmica: variação inter- e intra-linguística". No prefácio do livro, os organizadores (op. cit., p. 16) explicam a motivação para a junção das duas linhas teóricas: "Para eles os mesmos princípios e parâmetros deveriam dar conta da variação inter-linguística e intra-linguística e os conceitos de ‘encaixamento' estrutural e 'parâmetro' poderiam ser conciliados". ${ }^{17}$

A consolidação do termo PB no ambiente acadêmico brasileiro estendeu-se ao máximo, dando-lhe um enfoque 'metalinguístico', representativo da fala dos brasileiros. Mas alguns ecos dessa extensão do PB não foram resolvidos. Por exemplo, essa extensão de

\footnotetext{
${ }^{17}$ Sobre a metodologia de estudo que alia a teoria gerativa com o método variacionista há também críticas a ela uma vez que muitos sociolinguintas alegam que a teoria sociolinguística não é apenas um método quantitativo e qualitativo de análise linguística, mas também uma teoria da linguística social que é preterida pela abordagem paramétrica.
} 
sentido da expressão PB pode, de fato, ser representante da escrita e da fala dos brasileiros? Talvez, para o português escrito essa asserção seja, em parte, verdadeira, no entanto, é importante lembrar que as gramáticas publicadas recentemente (como as de Castilho (2010), Perini (2010) e Bagno (2011)) servem como contra-argumento a esse questionamento, pois, nelas, muitas prescrições de usos considerados 'errados' passam a ser 'aceitos' ou ganham status já que são contemplados em gramáticas que descrevem a fala dos brasileiros. Há muitas questões a se considerar e, muitas delas, a sociolinguística têm lançado luzes. O parâmetro escolaridade é tomado como a 'fronteira' que delimita o PB, variedade culta, falada por pessoas com formação universitária (noção presente nas bases do projeto NURC). Nesse sentido, a expressão PB é fortemente extensiva pois alcança uma generalização demasiada ao mesmo tempo que 'convive' ao seu lado uma outra variedade de português vernacular ou popular - o PVB.

No entanto, esse movimento em prol do PB esteve sempre envolvido a alguma polêmica, pois se, de um lado, gerou uma certa 'unicidade' do português brasileiro, com o apontamento de características com pretensões, muitas vezes, monolíticas e nem sempre bem acolhidas, dadas as dimensões e as especificidades linguísticas do país, os recortes das pesquisas aplicadas a uma dada região precisariam ainda ser cotejadas maximamente com os de outras regiões, mas nem sempre isso tem sido possível. Assim, mesmo havendo projetos como o NURC que realizou efetivamente um estudo ampliado, foi aplicado em apenas 5 capitais brasileiras. Outros estudos de descrição do PB são somente pontuais ou realizados em certas comunidades isoladas, mas, acolhidos sob uma postulação teórica universalista, ganham status de 'traço brasileiro', resultando, então, numa pseudo-homogeneidade.

Portanto, não penso ser possível que o termo português brasileiro seja representativo da universalidade em termos linguísticos, extensível ao país como um todo. Uma prova disto são os projetos desenvolvidos em algumas instituições, como o Vertentes Vestígios de Crioulização - (UFBA), cujos corpra foram a base para a publicação de $O$ Português Afro-Brasileiro; Português Paulista (USP, Unicamp, UNESP, UFSCAR), cujas peculiaridades não desqualificam o estatuto do $\mathrm{PB}$, mas servem para comprovar ou ao menos desmistificar a sua (não)unicidade. ${ }^{18}$

\footnotetext{
${ }^{18}$ Um exemplo disto é o Decreto-Lei $\mathrm{N}^{\mathrm{o}} \mathbf{7 . 3 8 7}$, de 09 de dezembro de 2010 que instituiu o Inventário Nacional da Diversidade Linguística (INDL) que considera as línguas faladas no país patrimônio imaterial da humanidade e que, como tal, devem ser documentadas e reconhecidas como "referência cultural". Volto a essa questão na próxima seção (1.4).
} 
Por trás das questões do português brasileiro não ser tratado de forma monolítica estão situações de contato, movimentos emigratórios e migratórios, a história social, e a origem étnica das populações locais tradicionais. Os substratos linguísticos das línguas ameríndias, as Línguas Gerais, assim como o substrato das línguas transplantadas de diferentes grupos linguísticos africanos. Enfim, uma teia de relações estabelecidas por meio do contato linguístico.

Outra questão a ser levantada, sobre o contato entre o português brasileiro (de modo geral) e as línguas faladas pelos africanos transplantados, centra-se na investigação da região de origem desses povos. Para Bonvini (2008, p. 30), o número de línguas (transplantadas) é bastante reduzido relativamente à quantidade de línguas inventariadas naquela região recentemente, razão que se deveu, à exploração restrita, inicialmente, apenas à costa africana em virtude das dificuldades de adentrar o interior do continente, fato que ocorreu apenas no final do século XVIII. Mesmo assim, para Bonvini (op. cit., ps. 30-31), o número real de línguas atingidas pelo tráfico de escravos é significativo e compreende duas áreas:

(i) a área oeste africana, caracterizada pelos grupos de línguas: a) atlântica: fula, uolofe, manjaco, balanta, b) mandê: bambara, maninca diúla, c) gur: subfamília gurúnsi, d) cuá: (subgrupo gbe): eve, fon gen, aja (designadas pelo termo jeje no Brasil), e) ijóide: ijó, f) benuê-congolesa: defóide: falares iorubas; edóide: edo; nupóide: nupe (tapa); ibóide: ibo; cross-River: efique, ibíbio; g) afro-asiático: chádica: hauça; h) nilo-saariana: saariana: canúri.

(ii) a área austral, essencialmente do grupo banto e faladas nas atuais repúblicas do Congo, República Democrática do Congo e Angola: congo: quissolongo, quissicongo, quizombo, quimbundo, quissama, quindongo, umbundo etc.

Assim, Figueiredo \& Oliveira (2013, ps. 112-3), no tocante às especificidades diacrônicas do português brasileiro, em geral, e das falas quilombolas, em particular, também consideram, seguindo Bonvini (2008), que a maioria dos escravos africanos que aportou no Brasil, após permanência no entreposto de São Tomé, era falante de L1 do grupo banto (área austral, cf. Bonvini). Os contingentes de escravos transplantados para o Brasil são, para Figueiredo \& Oliveira (op. cit., p. 112), identificados hoje como pertencentes a três grupos linguísticos: (i) Línguas bantas, escravos provenientes das atuais Repúblicas do Congo, República Democrática do Congo e Angola, (ii) Línguas cuá (subgrupo gbe) cujos falantes dessas línguas eram oriundos do chamado "Ciclo da Costa da Mina" e conhecidos 
ainda como "sudaneses", compreendendo as áreas atuais os países Gana, Togo, Benin e Nigéria e (iii) Línguas defóide (diferentes falares iorubás) cujos falantes eram provenientes da Nigéria; conhecidos no Brasil pelo termo nagô-queto (cf. Bonvini, 2008, p.30).

Sobre a investigação da origem dos grupos linguísticos transplantados para o Brasil. A figura 1 nos permite ter uma ideia parcial dessa distribuição:

\section{Figura 1 - Distribuição dos escravos africanos no Brasil}

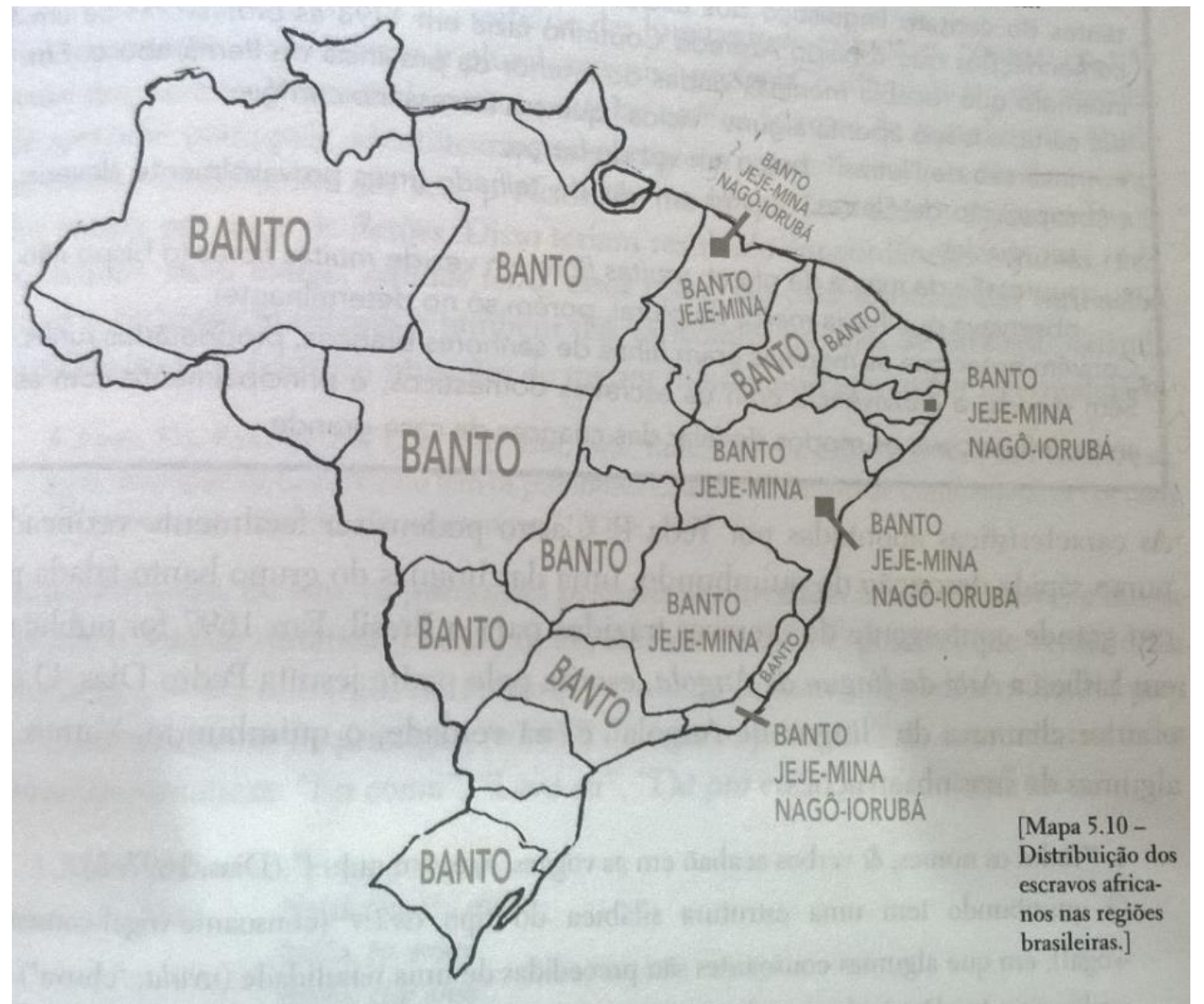

(BAGNO, 2012, p. 239)

No que se refere à região do Grão Pará e Maranhão, relativamente ao contato com línguas africanas naquela região, não é uma tarefa fácil a identificação de quais delas participaram das relações de contato. Desde que a cidade de Belém foi fundada, em 1616, as colônias portuguesas na América passaram a ter duas administrações distintas, ligadas diretamente à metrópole: (i) o Estado do Grão-Pará e Maranhão, que compreendia toda a Amazônia brasileira até o Ceará, e (ii) o Estado do Brasil, que englobava a outra parte do território. ${ }^{19}$

\footnotetext{
${ }^{19}$ Ver a referência $n^{\circ} .9$.
} 
As primeiras etnias escravizadas pelos colonizadores na Amazônia foram os indígenas e, somente mais tarde, os africanos. Mas a inserção de escravos oriundos da África na Amazônia, segundo Salles (2005[1971]), apesar da escassez de documentos comprobatórios, remonta ao século XVII:

“[...] não pode passar despercebida a informação da existência, já em 1693, da Igreja de N. S. do Rosário, devoção dos negros. Sabe-se, concretamente, que a irmandade do Rosário foi fundada em Belém a 9 de agosto de 1682. Ela teria a seu encargo não a igreja, o edifício atual, como se pode depreender da citação do cronista, mas de uma modesta ermida, demolida em 1752 e reconstruída no mesmo ano, com idênticas proporções e no mesmo lugar.

(SALLES, 2005, p. 44)

Com a paulatina redução da escravização de indígenas, até a sua proibição no século XVIII, a inserção de escravos africanos continuou a crescer. Salles (2005, ps. 80-82) descreve os ciclos que compreenderam o tráfico na região em diferentes modalidades: (i) o tráfico, (ii) o estanque ou estanco: criação das companhias - Companhia do Comércio do Maranhão (1682-1684), Companhia Geral de Comércio do Grão Pará e Maranhão (17551778), (iii) iniciativa particular, (iv) o contrabando, (v) o comércio interno (escravos importados das províncias de Pernambuco, Bahia e Rio de Janeiro).

Sobre a procedência do negro no Grão-Pará, Salles (op. cit.) diz ser uma indagação de resposta imprecisa, e, a partir da análise de documentos, busca montar o quebra-cabeças relativamente à origem dos negros introduzidos na região, cuja procedência tanto se liga à Alta Guiné quanto ao Golfo da Guiné:

A provisão de 18 de março de 1662 fala de negros de Angola, certamente da área de cultura banto. Já a provisão de $1^{0}$ de abril de 1680 fala de negros da Costa da Guiné, portanto de provável origem sudanesa [...] Negros Mina foram desembarcados no Pará e Maranhão, negros que se incluem na área das culturas sudanesas. Os negros chegados em 1753 de Bissau, capital da Guiné portuguesa, também podem ser incluídos nessa área. [...] No ano de 1759 chegou o navio N. S. da Conceição que embarcara com 500 negros da nação Moxicongo [...].

(SALLES, op. cit. p. 82)

Salles também aponta o caso dos escravos das famílias vindas de Mazagão, no atual Marrocos, assentadas pelos portugueses na nova cidade planejada nas margens do rio Mutuacá, no Amapá: ${ }^{20}$

\footnotetext{
${ }^{20}$ Os eventos da transferência da cidade marroquina de Mazagão para o atual Estado do Amapá são descritos por Assunção (2009, p. 8): “A decisão do governo português de mudar a cidade de Mazagão para a América portuguesa foi meticulosamente articulada. [...] Entre março e outubro de 1769, os mazaganistas viveram momentos de incerteza. A retirada de Mazagão levou os seus habitantes para Lisboa, numa viagem que durou
} 
[...] os negros introduzidos no Pará pelos portugueses da praça de Mazagão, transportados em 1769 e instalados em terreno adredemente preparado, nivelado e fortificado na Guiana brasileira. Das 340 famílias daquela praça africana, 163 foram localizadas na Nova Mazagão, com seus escravos. Não se sabe porém que escravos eram esses, de que parte do continente africano e pertencentes a que etnia: se eram islamizados ou arrancados das áreas de cultura sudanesa ou banto.

(SALLES, op. cit. p. 82)

Por último, Salles aponta a entrada de negros barbadianos, introduzidos na Amazônia pelos ingleses:

Nos fins do século XIX e começos do atual, houve interessante movimento migratório: negros barbadianos, isto é, originários da colônia inglesa de Barbados, Caribe, imigraram sobretudo para Belém, onde ainda há remanescentes. Esses negros, ostentando nomes anglo-saxônicos e falando o idioma inglês, chegaram em condições bastante favoráveis e galgaram posição social em diferentes setores; arte, magistério, economia etc.

(SALLES, op. cit. p. 84)

E, em nota de rodapé, explica:

$\mathrm{Na}$ verdade não houve migração convencional. O movimento migratório de barbadianos foi dirigido pelos capitalistas ingleses que obtendo sucessivas concessões para exploração de serviços no Pará e no Amazonas, necessitaram de mão-de-obra qualificada, do ponto de vista da língua e da cultura, provavelmente. Os negros de Barbados, domesticados pelos ingleses, foram trazidos pelos navios que faziam a linha Nova YorkManaus, com escala na ilha de Barbados e Belém. [...] Muitos foram destinados também à construção da ferrovia Madeira-Mamoré.

(SALLES, op. cit. nota 130, p. 84)

Ainda é interessante uma observação dos fenômenos de contato forjados entre as diferentes etnias no Grão-Pará. A pesquisa de Gomes (1997) sobre a formação de mocambos e quilombos na Capitania do Grão-Pará e também do Rio Negro revela um cenário cheio de movimento de fugas e de formação de quilombos na fronteira colonial, principalmente da Guiana Francesa. Segundo Gomes (op. cit., p. 28) nesta região, especialmente no Amapá, os mocambos também foram aumentados com as constantes deserções de soldados: “(...) outro fato discutido nesta Capitania é o movimento de fugas e o surgimento de 'mocambos de índios', destacadamente, a partir de 1760” (op. cit., p. 28).

aproximadamente onze dias. Entre os dias 21 e 24 de março, as catorze embarcações ancoraram no rio Tejo. Sebastião José de Carvalho e Melo já havia definido qual seria o destino desses vassalos. A intenção da coroa portuguesa era transportar todas as famílias para a América portuguesa, provendo-as dos recursos necessários para que se acomodassem na região adjacente a Belém do Pará. Conforme determinação real, deveria ser estabelecida uma nova povoação na costa septentrional do Amazonas para se darem as mãos com o Macapá e com a Villa Vistoza". 
Gomes (op. cit., p. 28), cita documentos indicando a formação de mocambos de negros e índios e as relações destes com povoados nas fronteiras:

Seguiremos aqui, em parte, um argumento de Craton para o Caribe, demonstrando que a experiência dos mocambos (maronage) é também afro-american, ou seja, contou tanto com as experiências trazidas pelos africanos como aquelas das populações indígenas.

(Gomes, 1997, p. 28-9)

Em 1849, o comandante militar do Alto Amazonas informava que os cativos das fazendas locais podiam estar entrando em contato com os "pretos e mestiços de Demerara [que] se achão sublevados contra o Governo da Guiana Inglesa"21. Cinco anos antes, o comandante do Forte Tabatinga denunciava que os fugitivos escravos estavam atravessando a fronteira com a "república peruana". Dizia-se o mesmo a respeito da Venezuela. Quilombolas, mestiços, "homens livres e de cor" - sendo a maior parte de ex-cabanos -, indígenas e regatões estavam espalhando e reinventando suas tradições de liberdade, nas quais podiam estar inseridas danças e cantos como o Camougue da Guiana Francesa. Pode parecer incrível, mas, entre eles, havia até mesmo ex-marinheiros ingleses que tinham abandonado seus serviços nos portos paraenses e se juntado aos "rebeldes" no "tempo da malvadeza", como era chamado o período da cabanagem.

(Gomes, 1997, p. 30)

$\mathrm{Na}$ área quilombola de Jurussaca, para além de seus fundadores, provavelmente, escravos fugidos, a região era também habitada por indígenas. A etnolinguística da comunidade vem sendo atestada como afro-indígena (cf. Oliveira et alii (no prelo), Oliveira \& Praça (2013), Antunes, Oliveira \& Praça (2013). Baseando-se na morfologia territorial da comunidade, Cecim (2014, p. 81) aponta que a área fora habitada por indígenas do tronco Macro-Jê. No terceiro capítulo desta tese retomo essa temática.

Por fim, a compreensão dos fenômenos de mudança que marcam a gramática do português brasileiro terá de levar em conta as questões sociolinguísticas que permearam e forjaram as relações de contato a que a língua portuguesa teve acesso. Essa realidade linguística já foi bastante explorada no decorrer deste capítulo, mas retomo aqui algumas questões centrais:

(i) a existência de um fosso entre os falares da elite e os falares populares, resultado da "polarização linguística brasileira" (apontado por Lucchesi, 2009);

(ii) a situação de diglossia linguística resultante do ensino massivo tardio do português;

\footnotetext{
${ }^{21} \mathrm{O}$ termo Demerara diz respeito à região situada na costa norte da América do Sul, na atual Guiana: Foi uma colônia holandesa até 1815 e um condado da Guiana Inglesa 1838-1966.
} 
(iii) o isolamento de algumas comunidades, a estratificação social e a baixa escolaridade como fatores de manutenção de continua linguísticos;

(iv) o panorama histórico da Amazônia Colonial cheio de movimento de fugas, rebeliões e formação de mocambos e quilombos aponta para uma forte miscigenação entre diferentes etnias, desvelando um rico cenário de contato linguístico na região.

(v) Os fenômenos que marcam a mudança no PB

1.4. Das especificidades do PB ou da desconstrução da pseudo-homogeneidade: em busca de um continuum de português

$\mathrm{Na}$ seção anterior, procurei discutir a generalização da expressão PB, tentando mostrar o percurso que permitiu sua assunção como 'elemento homogêneo', principalmente entre linguistas gerativistas que, apoiados na tese dos universais linguísticos, embasados, principalmente, pelos pressupostos de Princípios \& Parâmetros (CHOMSKY, 1986), buscaram postulações, generalizações e sistematizações, na tentativa da descrição da 'gramática do PB'. Nesse sentido, houve avanços singulares em vários campos de estudo da língua portuguesa e um número imenso de teses sobre o PB em cotejo com o PE foram produzidos. Esses trabalhos alargaram o escopo sobre o conhecimento do português genuinamente brasileiro, chegando à generalização do termo PB a que se tem nos dias de hoje.

Nesta seção menciono a terceira característica que atribuí ao PB na introdução do capítulo - da necessidade de revisão da generalização a que se chegou, ou mesmo, da desconstrução da 'pseudo-homogeneidade'. Antes, porém, passo às questões que motivam a necessidade dessa discussão.

$\mathrm{Na}$ área de políticas públicas e de direitos humanos, iniciou-se, há alguns anos, um movimento de reivindicação de instituição de uma "política patrimonial" para as línguas brasileiras, em vistas à realidade vivenciada em inúmeras regiões do país, onde vários grupos de brasileiros falam também outras línguas que expressam visões de mundo, valores e significados fundamentais para a história e a identidade desses grupos e da própria nação.

Empenhados nesse esforço, grupos e comissões ligados à educação e à cultura nacionais, nomeadamente a Comissão de Educação e Cultura da Câmara Federal, o Instituto de Investigação e Desenvolvimento em Política Linguística (IPOL), associados ao Instituto 
do Patrimônio Histórico e Artístico Nacional (IPHAN), obtiveram deste Instituto uma portaria que dispunha sobre o reconhecimento do Grupo de Trabalho da Diversidade Linguística do Brasil (GTDL), ${ }^{22}$ criado por representantes de várias instituições governamentais e não governamentais para tratar de políticas públicas voltadas à preservação e à proteção do multilinguismo no país, conforme se pode atestar no excerto retirado do Relatório de Atividades do Grupo $^{23}$ :

$(\ldots \ldots \ldots)$

2. Elementos estruturadores da política nacional de reconhecimento e de inventário da diversidade linguística.

\section{a) Inventário}

Implementação de uma política de Inventário como etapa indispensável para o conhecimento e disseminação de dados sobre a diversidade linguística brasileira e também como um instrumento de reconhecimento e salvaguarda das línguas como patrimônio cultural

\section{b) Metodologia}

Necessidade de se estabelecer parâmetros comuns quanto ao escopo e a metodologia do Inventário, de forma a garantir a qualidade e a comparabilidade das informações, diante da diversidade de situações a serem descritas. Para o desenvolvimento deste tópico, foi constituído um subgrupo, composto pelos membros do GTDL com formação em linguística, que elaborou uma proposta que, discutida e aprovada pelo grupo, encontra-se anexada à minuta de decreto presidencial instituindo o Inventário Nacional da Diversidade Linguística - INDL (ver tópico c). O escopo básico da metodologia geral do Inventário encontra-se descrito no Anexo I.

No que toca ao levantamento de dados, entende-se que, como sua implementação será descentralizada, inclusive integrando pesquisas já realizadas e experiências já acumuladas por pessoas e instituições, será necessário definir um padrão metodológico contendo as referências para adaptação dos procedimentos de campo às diversas situações encontráveis e em conformidade com o contexto linguístico investigado. Tais adaptações seriam submetidas à aprovação do grupo gestor do INDL.

Avaliou-se também a conveniência de se testar a metodologia geral do INDL em projetos-piloto abrangendo a seguintes situações:

a) duas línguas indígenas, uma falada por poucos indivíduos e outra falada por comunidade numerosa;

b) uma língua de imigração;

c) uma língua de sinais;

d) uma língua de comunidade afro-brasileira;

e) uma língua crioula.

O termo denominador das línguas que serão inventariadas foi também bastante discutido, concluindo-se que em vez de "falares" se adotaria a expressão "variedades dialetais" para o caso das comunidades lusobrasileiras e para as manifestações linguísticas das comunidades afro-

${ }^{22}$ O GTDL foi oficialmente criado a partir da Portaria $\mathrm{N}^{\circ} 274$, de 03 de setembro de 2007, expedida pelo Instituto do Patrimônio Histórico e Artístico Nacional-IPHAN.

${ }^{23}$ ALMEIDA, L. Fernando (2007) Relatório de Atividades do GTDL 2006-07. 
brasileiras foi proposto o termo "línguas de comunidades afro-brasileiras". Adotou-se a seguinte categorização para as expressões linguísticas passíveis de inclusão no INDL.

a) línguas indígenas,

b) variedades dialetais da língua portuguesa;

c) línguas de imigração;

d) línguas de comunidades afro-brasileiras;

e) línguas brasileiras de sinais;

f) línguas crioulas.

\section{c) Suporte Legal}

A fim de que o INDL possa se efetivar como um instrumento de reconhecimento patrimonial e salvaguarda, verificou-se a necessidade de se propor um dispositivo legal que o institua como tal. Avaliou-se que, diante da necessidade de agilidade e da urgência na implementação da política de salvaguarda da diversidade linguística brasileira, e ainda, para que essas ações sejam inseridas no Plano Plurianual PPA e na Lei de Diretrizes Orçamentárias do próximo ano, o mais aconselhável é a sanção de um Decreto Presidencial (ver Anexo II), a exemplo do adotado para o Registro de Bens Culturais Imateriais (Decreto $n^{\circ} 3551$, de 4 de agosto de 2000).

(ALMEIDA, L. F., 2007 - Relatório de Atividades do GTDL) ${ }^{24}$

A partir do trabalho inicial do GTDL, foi sancionado, pelo Governo Federal, por meio do Decreto-Lei $N^{0} \cdot 7.387$, de 09 de dezembro de 2010, o Inventário Nacional da Diversidade Linguística (INDL) ${ }^{25}$ que considera as línguas faladas no país patrimônio imaterial da humanidade e que, como tal, devem ser documentadas e reconhecidas como "referência cultural".

Dentro do escopo do INDL, como já mencionado acima, está o Projeto-Piloto IPNHAN/USP $n^{\text {o. }}$ 20173, realizado nos anos de 2010 e 2011, que fez parte de um conjunto de projetos-piloto que precederam a criação do Inventário Nacional da Diversidade Linguística (INDL). O Projeto IPHAN/USP: Levantamento etnolinguístico de comunidades afro-brasileiras de Minas Gerais e Pará, coordenado pelas Profas. Dras. Margarida Petter e Márcia Oliveira, da Faculdade de Filosofia, Letras e Ciências Humanas - FFLCH - teve como objetivo geral:

[...] elaborar um banco de textos orais coletados em duas comunidades quilombolas de Minas Gerais - Tabatinga (Bom Despacho/MG) e Milho Verde (MG) - e uma do Pará - Jurussaca (Tracuateua) - para avaliar a eventual presença de traços de línguas africanas, a partir da comparação de dados atuais com trabalhos publicados sobre a 'linguagem' daquelas regiões. Mais especificamente, as metas desta proposta são:

- levantar a história dessas comunidades por meio de pesquisa em fontes escritas e orais;

\footnotetext{
${ }^{24}$ Ver documento na íntegra na seção Anexos - Anexo 3

${ }^{25}$ O Decreto-Lei N ${ }^{0}$.7.387 que criou o INDL consta na seção Anexos desta tese - Anexo 2
} 
- examinar a permanência de línguas/culturas africanas em espaços afrobrasileiros;

- coletar textos de diferentes gêneros de discurso (narrativas, explanações, descrições, falas rituais, cantos, diálogos, conversas, fórmulas de cura, lendas, adivinhas, provérbios);

- organizar um banco de dados histórico, linguístico e cultural sobre as comunidades investigadas;

- organizar um glossário dos termos de origem africana e/ou termos próprios da fala desses moradores;

- descrever, visando a análises, aspectos morfossintáticos da variante oral do português identificada nas comunidades;

- comparar aspectos descritivos e análises do português falado nessas comunidades com outras descrições/análises já realizadas em outras comunidades quilombolas do sudeste e nordeste brasileiro;

- comparar ainda esses aspectos com descrições/análises já realizadas sobre a variedade culta do português falado no Brasil;

- realizar uma amostra da organização social dessas áreas.

A coleta, armazenamento e análises preliminares dos dados são norteados pelas seguintes hipóteses: (i) o português falado por essas comunidades afro-brasileiras apresenta distinções significativas se comparadas ao português falado em outras regiões do país; (ii) essas distinções podem estar associadas ao contato com línguas africanas; (ii) o estudo da organização social pode apontar para características comuns existentes em sociedades do oeste africano.

(PETTER \& OLIVEIRA, 2011a)

Um dos aspectos centrais do Decreto que instituiu a Lei INDL é a ratificação de que o português brasileiro não é uma língua monolítica, mas ao contrário, a afirmação de que o Brasil é um país multilíngue, não apenas em consideração às línguas de imigração, as autóctones e a de sinal (com suas variedades), mas também pelas especificidades da própria língua portuguesa (concebida como não homogênea), expressa nas categorizações adotadas pelo GTGL para o procedimento das variedades a serem inventariadas e passíveis de inclusão no INDL que se reivindicava naquele momento: "variedades dialetais da língua portuguesa" e "línguas de comunidades afrobrasileiras", do Relatório de Atividades do GTDL.

É importante destacar que a criação do INDL traz um embasamento legal para o reconhecimento e a oficialização de línguas faladas por populações minoritárias e, consequentemente, a possibilidade de estas línguas serem ensinadas em rede pública. No ano de 2002, no município amazonense de São Gabriel da Cachoeira, em situação inédita no Brasil, a Câmara Municipal aprovou a lei $\mathrm{n}^{\circ}$ 145, que oficializou três línguas faladas na região: baniua, nheengatu e tucano, fazendo da cidade a primeira no país com língua oficial, além do português. A iniciativa de São Gabriel da Cachoeira, embora louvável e de vanguarda no país, chega com séculos de atraso, pois desde que foram implementadas as 
políticas da reforma pombalina - com a Lei do Diretório dos Índios (1757), proibindo o uso da Língua Geral e acelerando o processo de expansão da língua portuguesa por todo o território brasileiro -, foram negados todos os direitos linguísticos dos falantes de outras línguas em território brasileiro. ${ }^{26 / 27}$

Müller (2005), um dos idealizadores do Projeto que resultou na referida Lei, criada na cidade de São Gabriel da Cachoeira, relata como surgiu a ideia pioneira no país, abrindo caminho para que outras comunidades tenham seus direitos reconhecidos:

Atuamos como docentes em um curso de formação de docentes indígenas com cinco anos de duração que formou 165 professores falantes de 11 línguas diferentes. Deste curso, cujo encaminhamento possibilitou aos professores falantes destas línguas discutirem entre outras coisas, o lugar das suas línguas na sociedade local, surgiu a idéia de elaborar uma lei para, através da aprovação da câmara dos vereadores, oficializar as três grandes línguas veiculares do município, o Nheengatu, ou Língua Geral Amazônica, que outrora dominou toda a Amazônia brasileira e hoje é falada quase que exclusivamente no Alto Rio Negro, o Tukano, língua dominante na Bacia do Rio Vaupés, da família Tukano Oriental, e o Baniwa, importante língua Aruak que domina a bacia do Rio Içana. A idéia foi levada a uma assembléia geral da Federação das Organizações Indígenas do Rio Negro (FOIRN) com cerca de 500 delegados das 42 organizações de base que a integram, e foi aprovado, no início de 2001, um pedido da FOIRN ao IPOL para a elaboração do ante-projeto de lei e sua justificativa.

(MÜLLER, 2005, p. 90)

Com a instauração de uma "política patrimonial" de que resultou a criação do INDL, ratificou-se uma discussão antiga relativamente à formação histórica do português brasileiro e abriu-se novamente um espaço na agenda dos estudos linguísticos para tais discussões. Assim, mais uma vez, vem ganhado bastante evidência a consideração das variedades locais como o resultado das relações de contato linguístico que alteraram, de algum modo, a 'língua original' ${ }^{28}$ As variedades de português faladas no Brasil, das mais ou menos marcadas por situações de contato, estariam situadas dentro de um continuum de português, indo das variedades mais populares ao português brasileiro falado standard. (MELLO, 1996). O PB (standard) deixaria de ser visto como homogêneo ou genérico,

\footnotetext{
${ }^{26}$ A Lei ${ }^{\circ} 145$ do município de São Gabriel da Cachoeira foi idealizada pelo linguista Gilvan Müller de Oliveira. Sobre a Lei, ver a matéria publicada na Folha de São Paulo on line em 07.07.2009, nos Anexos desta tese - Anexo 3

${ }^{27} \mathrm{O}$ talian, língua falada no Brasil pelos imigrantes italianos, é uma variante da língua do norte da Itália, da região de Vêneto. Encontra-se mais informações sobre o talian na Revista talian: http://talian.net.br/.

${ }^{28} \mathrm{O}$ contato linguístico é um fator externo à língua e pode ser visto como elemento desencadeador de diferentes processos, conforme o quadro teórico que se adota. Dentro da tradição estruturalista, as mudanças ocorridas em uma dada língua, se analisadas sob o enfoque do contato linguístico, como no caso do português brasileiro, pode ser a explicação de mudanças resultantes de uma deriva secular da língua, acelerada por fatores externos como o contato.
} 
representando apenas a parte que lhe cabe dentro do continuum. Nesse sentido, o português brasileiro, não seria um 'bloco' único, mas vários blocos de um único composto. Por trás dessa assunção está a compreensão de que é necessário se voltar às partes na busca do todo. O que explica essa característica são as especificidades e diferentes realidades que compõem a sociedade brasileira, quer regionalmente, socialmente, nos níveis da educação, de idade, quer de etnia etc., entendendo a expressividade do português brasileiro como um continuиm que vai do mais marcado, em um extremo, ao que é aceito nas esferas mais altas (e não marcado), no extremo oposto.

Relativamente às situações de estratificação social do Brasil, tem-se afirmado claramente a existência de um fosso entre um PB, representado pelos falantes cultos e um PVB, língua vernacular ou popular. Essas duas variedades convivem entre si, ao mesmo tempo que são marcadas em vários níveis gramaticais (“polarização linguística do Brasil”, nos ternos de Lucchesi, 2009). Portanto, atualmente, um grupo de lingusitas vem preferindo não mais tomar o conceito de $\mathrm{PB}$ de modo generalizado, face às questões relacionadas às implicações históricas da língua a partir do forte 'contato linguístico' que ocorreu no país. (sobre o assunto, ver FIGUEIREDO \& OLIVEIRA (2013), entre outros).

Outro fator importante a se considerar, é que essa tendência não parte do conceito de dialeto, por compreensão de que não é apenas uma questão ligada ao usuário da língua em sua dimensão sociogeográfica. Nesse sentido, o "Português Afrobrasileiro da Bahia", descrito em Lucchesi, Baxter \& Ribeiro (2009) e falado em comunidades como Helvécia, não tem sido considerado, ao menos expressamente, pelo grupo de pesquisadores envolvidos nessa pesquisa, como uma expressão da dimensão dialetal:

O conceito de português afro-brasileiro fundamenta-se, não em parâmetros étnicos, mas em parâmetros sócio-históricos. Não se reconhece no Brasil uma fronteira linguística determinada por fatores étnicos. (...) Estima-se, por exemplo, que aproximadamente $85 \%$ da população da cidade de Salvador seja constituída por afrodescendentes. Entretanto, pode-se dizer que muito provavelmente nenhum deles é falante do português afrobrasileiro, no sentido em que esse termo é empregado aqui. (...) $\mathrm{O}$ português afro-brasileiro designa aqui uma variedade constituída pelos padrões de comportamento linguísticos de comunidades rurais compostas em sua maioria por descendentes diretos de escravos africanos que se fixaram em localidades remotas no interior do país (...). Nesse contexto, as comunidades rurais afro-brasileiras isoladas constituem um espaço único para a pesquisa em linguística sócio-histórica que visa a rastrear os reflexos do contato entre línguas na estrutura gramatical das variedades atuais do português brasileiro, pois os efeitos do processo de transmissão linguística irregular sobre a estrutura gramatical da língua no Brasil seriam mais notáveis exatamente nessas comunidades, em função da combinação das 
condições históricas em que elas se formaram com o isolamento em que se conservaram até recentemente.

(LUCCHESI, 2009a, ps. 31 a 33)

O conceito de dialeto liga-se diretamente ao de variação linguística como uma de suas fontes. Leite (2005, p. 187) menciona a existência de dois eixos básicos de variação da língua: o usuário, com sua configuração sociogeográfica, que dá origem ao que se denomina dialeto, e $o$ uso, com todas as nuanças de variação de situação, que dá origem ao que se denomina registro ou níveis de linguagem (e se configura pelo maior ou menor grau de formalidade nos contatos sociais). Desse modo, o conceito de dialeto liga-se diretamente ao falante ou usuário da língua, sua origem geográfica e classe social. Leite (op. cit., p. 186), citando Halliday (1974), reforça o conceito de dialeto:

Em determinada dimensão, a variedade de uma língua que um indivíduo usa é determinada pelo que ele é. Todo falante aprendeu, como sua L1, uma particular variedade da língua de sua comunidade linguística e essa pode ser diferente em algum, ou em todos os níveis de outras variedades da mesma língua apreendidas por outros falantes como sua L1. Tal variedade, identificada segundo essa dimensão, chama-se dialeto.

(HALLIDAY, 1974, p. 105)

Aliás as fronteiras que separam dialeto de língua, para Chomsky (1986), são questões ideológicas e políticas cujas definições não são precisas nem coerentes:

In the first place, the commonsense notion of language has a crucial sociopolitical dimension. We speak of Chinese as "a language", although the various "Chinese dialects" are as diverse as the several Romance languages. We speak of Dutch and German as two separate languages, although some dialects of German are very close to dialects that we call "Dutch" and are not mutually intelligible with others that we call "German". A standard remark in introductory linguistics courses is that a language is a dialect with an army and a navy (attributed to Max Weinreich). That any coherent account can be given of "language" in this sense is doubtful; surely, none has been offered or even seriously attempted.

$(\text { CHOMSKY, 1986, p. 15) })^{29}$

Portanto, com base apenas no conceito de dialeto, ligado à dimensão do falante (LEITE, 2005), não se abarcam questões de fundo sociohistórico preponderantes ainda para

\footnotetext{
29 Tradução aproximada: "Em primeiro lugar, o senso comum da noção de língua tem uma dimensão sóciopolítica crucial. Falamos de chinês como "uma língua", embora os vários "dialetos chineses" são tão diversos quanto as diversas línguas românicas. Falamos de holandês e alemão como duas línguas diferentes, ainda que alguns dialetos do alemão sejam muito próximos de dialetos do "holandês" e ininteligíveis face a outras que chamamos de "alemão". Uma observação padrão em cursos introdutórios de linguística é que uma língua é um dialeto com um exército e uma marinha (atribuído a Max Weinreich). Nesse sentido, qualquer explicação coerente que pode ser dada ao conceito de "língua" é duvidosa; certamente, ninguém o fez ou mesmo foi seriamente tentado a fazê-lo".
} 
o entendimento do português brasileiro. Um exemplo que se pode dar é a própria comunidade em foco nesta tese, que foi alvo de projeto-piloto que antecedeu à criação do INDL, citado no início desta seção.

Além da dimensão dialetal, discutida acima, uma outra questão esteve por trás das origens do PB: a temática de sua origem crioula. Nas décadas de 1980 e 1990, a tese crioula para o PB (levantada anteriormente por filólogos) retorna a agenda dos estudos relacionados à gênese dessa língua. Três pesquisadores destacam-se: Guy (1981, 1989), Holm (1987) e Baxter (1987, 1988) que, com base em suas análises, hipotetizaram que, no Brasil, desenvolveu-se um tipo de relacionamento social e de situações que costumam levar à crioulização (tal como se deu em crioulos de base lexical portuguesa falados na África).

A tese crioula postulada para o PB foi contesta por Tarallo $(1986,1993)$ por meio de dois grandes argumentos: (i) caso o português brasileiro tivesse, de fato, se originado de um crioulo de base lexical portuguesa, deveria estar agora em fase de descrioulização, seguindo na direção da língua-alvo, o PE; (ii) diferentemente, as evidências de mudanças sintáticas apontam em sentido contrário. Tarallo (1993, p. 61) afrima que foi a rigidez da língua escrita padrão que manteve as variedades PE e PB próximas. Para Tarallo, foram as gramáticas faladas que tomaram rumos diferentes.

A tese crioula para o PB foi ainda contestada por outra tese que se tornou conhecida como "deriva secular" - Naro \& Sherre (1993). Esses autores resgatam o conceito sapiriano de deriva linguística, afirmando que as mudanças que ocorrem no PB resultam de uma tendência presente na evolução da língua portuguesa desde suas origens latinas. Logo, esses autores negam qualquer motivação de contato linguístico como única explicação para a gênese do PB.

Nos anos seguintes, a partir da década de 1990, ressurge a linguística de contato $^{30}$, a partir de um grande expoente na literatura do contato: Thomason \& Kaufman (1988) e, mais tarde, Mayers-Scotton (2002). No Brasil, Baxter (1995) com o conceito de Transmissão Linguística Irregular, retomado por Lucchesi (2006, 2009); Melo (1996) sobre o continuum dialetal; o conceito de ecologia linguística, de Couto (2009), entre outros.

Com a crescente discussão sobre o contato entre línguas, na década de 1990, voltam à pauta os estudos crioulistas. Hildo do Couto funda a revista PAPIA, na Universidade de Brasília, considerando que os crioulos de base ibérica permanecem quase inexplorados. Alan

\footnotetext{
${ }^{30}$ Os estudos relativamente ao contato linguístico remontam ao século XIX, com o desenvolvimento da linguística histórico-comparada desenvolvida por Franz Bopp, Friederich Diez, August Schleicher, Hugo Schuchardt etc.
} 
Baxter (1995) e Dante Lucchesi (2009) redefiniram o crioulo do ponto de vista da história social como "uma língua que nasce em circunstâncias sócio-linguísticas especiais que conduzem à aquisição de uma primeira língua, com base em um modelo defectivo de segunda língua" (op. cit. ps. 40-69). Eles levantam a hipótese de que certas variedades de português, como a da comunidade de Helvécia poderiam, inclusive, ter sido uma 'língua crioula' em tempos remotos, dadas as especificidades morfossintáticas atestadas ainda hoje. ${ }^{31}$ Por trás dessa assunção, está, novamente, a questão da crioulização como hipótese da origem social do português brasileiro.

Sobre esse debate, presente em vários momentos, é interessante observar o que diz Pagotto (2007):

\begin{abstract}
A questão crioula, ao contrário do que insinua Tarallo, deve continuar na nossa pauta de trabalho. É até possível que se encontrem traços mais característicos de línguas crioulas em algumas comunidades isoladas. Não se deve, porém tomar tais casos como prova de que o português do Brasil, como um todo, teria sido fruto de um processo de crioulização - não importa o lado, o peso de um lado só da balança sempre escamoteia questões importantes e acaba produzindo uma visão distorcida. Mais importante é explicar de que maneira as propriedades gramaticais encontradas no português do Brasil podem estar historicamente ligadas a uma origem crioula e analisar por que frestas no sistema tais propriedades penetraram. Somos um pouco de tudo, frutos de um processo histórico que ainda está por explicar.
\end{abstract}

(PAGOTTO, 2007, p. 481)

Dentro do conjunto de hipóteses para o surgimento das propriedades gramaticais do português brasileiro, de que venho falando, menciono a hipótese levantada por Holm (2004) para o português vernacular do Brasil - PVB. Holm apresentou a proposta sobre a 'reestruturação parcial' de cinco línguas, nomeadamente: o inglês afroamericano, o Afrikaans, o português vernacular brasileiro, o espanhol caribenho não-padrão e o francês vernacular de Réunion. Holm (op. cit.) discute, inicialmente, a confusão terminológica de base teórica relativamente à temática da 'reestruturação parcial' e 'descrioulização'. Segundo Holm, embora as características do contexto social que deram origem às variedades mencionadas sejam muito generalizadas, as características linguísticas podem ser parecidas, propondo que a 'reestruturação' ocorreu nas línguas estudadas em termos de uma série de processos linguísticos parecidos. Para ele o português vernacular reúne características para ser observado como uma língua "parcialmente reestruturada" (no que se difere, então, para o

\footnotetext{
${ }^{31}$ Pesquisas na década de 1970 e 80 na comunidade de Helvécia, levaram Guy (1981) a levantar a hipótese de que o português brasileiro tenha sido um crioulo, hipótese fortemente combatida por Tarallo (1996a) entre outros.
} 
autor, das línguas crioulas que são "completamente reestruturadas"). O fator social mais relevante na determinação da estrutura de uma língua parcialmente reestruturada, apontado por Holm (2004, ps. 135-6) é a relação demográfica entre falantes nativos e não nativos dessa língua. Em línguas parcialmente reestruturadas os grupos envolvidos, demograficamente 'equilibrados', não chegam a ser numerosos o suficiente para sobrecarregar um ao outro culturalmente. Para Holm (op. Cit.), este é o principal fator social de diferenciação entre as línguas parcialmente reestruturadas e as línguas completamente reestruturados, como línguas crioulas, que se desenvolveram em um contexto social onde o grupo Africano era consideravelmente mais numeroso do que o grupo europeu. Nesse sentido, a proposta de 'reestruturação parcial' de Holm, para o PVB, encaixa-se também nos estudos sobre a linguística de contato.

Ainda sobre o contato de línguas no Brasil, convém mencionar mais detalhadamente os estudos de Lucchesi (2006, 2009) sobre a 'transmissão linguística irregular'. Ao considerar a 'polarização linguística' ocorrida no Brasil, decorrente da 'transmissão linguística irregular'. Lucchesi (op. cit.) refere-se à intensidade com que o contato entre línguas permeou a variedade de português falada no Brasil e chama a atenção para as diferenças que ocorrem entre falantes de comunidades afrobrasileiras:

[...] Não se podendo, portanto, pensar o português afro-brasileiro como uma realidade linguisticamente homogênea, a diferença entre ele e o que se pode chamar de português rural brasileiro, ou mesmo português popular do interior do país será igualmente variável em função do recorte feito, ou seja, das comunidades em cotejo em cada caso".

(LUCCHESI, 2009, p. 81)

No tocante ao paradigma pronominal, na comunidade de Helvécia (BA), segundo Lucchesi (2009, p. 334), a erosão gramatical atingiu todo o paradigma da flexão de pessoa e número do verbo, apontando para a hipótese de que, em algumas comunidades, o contato entre línguas foi mais intenso.

Por outro lado, para além da variedade de português falada pelas ditas 'comunidades afrobrasileiras', é interessante levar em conta as observações de Pagotto (2007) ao considerar o 'conjunto de características comuns', partilhadas pelos dialetos populares de norte a sul do Brasil:

Dentre os fatos que mais impressionam no português do Brasil, temos que ele caracteriza, de norte a sul, por um conjunto de características comuns. A tão propalada unidade linguística no Brasil é, assim, mais interessante não quando se toma os falares cultos, mas especialmente quando se tomam os dialetos populares das mais diversas regiões. É claro que há diferenças regionais entre os vários dialetos brasileiros, mas chama a atenção que em 
todo o Brasil os diversos dialetos populares se oponham ao português erudito segundo um mesmo conjunto de traços na morfologia e na sintaxe. É aqui que se localiza a unidade do português brasileiro. Dado o tamanho de nosso território é claro que se torna irresistível perguntar como esta unidade se teria dado historicamente.

(PAGOTTO, 2007, p. 469).

Apesar de Pagotto (op. cit.) não se referir ao PVB em contraponto ao PB, conforme tem sido aqui mencionado, o autor fala de dialetos populares, atentando para as diferenças entre eles, em oposição ao 'português erudito' e ao 'português de Portugal':

Antes de mais nada, é preciso duas ressalvas quanto a esta suposta unidade linguística. Em primeiro lugar, não significa homogeneidade na sintaxe ou na morfologia quanto a todos os traços relevantes que caracterizam uma gramática, mas que, quanto a um certo núcleo da gramática se pode depreender um mesmo conjunto de traços que opõe o que podemos chamar de português popular ao português erudito e ao português de Portugal.

(PAGOTTO, 2007, p. 469)

E Pagotto (op. cit., p. 469) conclui com uma interessante observação: "não se tem notícia de dialetos populares que façam uso do clítico acusativo, nem da relativa padrão, por exemplo [...] da mesma forma não se tem notícia de dialetos populares que realizem a ênclise em sentenças simples".

Em síntese, tanto a proposta de Holm (2004) sobre a 'reestruturação' parcial do PVB, quanto a de Lucchesi $(2006,2009)$ de 'transmissão linguística irregular' com vistas para o português afro-brasileiro, quanto as observações de Pagotto (2007) sobre o conjunto de 'características comuns' do português popular cabem na proposta de postulação de um continuиm para o estudo dessas variedades já que por trás de todas elas, está o forte contato linguístico por que passou o português brasileiro.

Aliás, é importante destacar que a proposta sugerida inicialmente por BortoniRicardo (1985) de se observar as variedades de português dentro de um continuum, retomada por outros autores, como Mello (1996) e Petter (2008), embora, inicialmente, estivesse ligada à ideia de dialetação (continuum dialetal), a proposta de Petter, apresentada anteriormente, não ratifica a ideia inicial de continuum sob o enfoque da noção de dialeto ou de variação regional vs. social. A proposta de Petter parte das situações de contato linguístico estabelecido entre a língua portuguesa quer com línguas banto ou sudanesas, quer com ameríndias ou de imigrantes que motivaram as variações ou mudanças do PB atual (razões para que a autora proponha cotejo do $\mathrm{PB}$ com o PA e o PM); o que não exclui, necessariamente, as noções de variação regional e social, mas as toma como consequentes do contato linguístico. 
Um argumento a acrescentar, sobre a linguística de contato é o fato de as concepções (ligados ao contato) não estarem centradas em um único campo de investigação ou de pressupostos teóricos. Na Universidade de São Paulo, por exemplo, há pesquisadores ligados às concepções funcionalistas e/ou gerativistas, desenvolvendo estudos cujas hipóteses estão centradas no que se tem chamado de linguística do contato. Um marco dos estudos brasileiros nessa área é, por exemplo, como já mencionado, a criação da Revista PAPIA, com sua primeira publicação em 1990 e, o consequente surgimento de associações e de grupos de estudos, como a fundação da Associação Brasileira de Estudos Crioulos e Similares - ABECS, no ano de 2000, na Universidade de Brasília e a criação do Grupo de Estudos em Línguas em Contato - GELIC, na USP, em 2010.

Para finalizar, a concepção de um PB monolítico estaria, totalmente na contramão das questões levantadas sobre contato linguístico e da tendência de reconhecimento das comunidades linguísticas minoritárias no Brasil, como a Lei criada no município amazonense de São Gabriel da Cachoeira que oficializou três línguas indígenas. Portanto, faz pouco sentido a concepção de um PB monolítico, nos termos que discuti anteriormente. Assim, todas as hipóteses formuladas para as origens do PB (a da deriva, a de substratos das línguas locais ou de substrato de línguas africanas, a reeestruturação parcial) são legítimas, pois seguem as condições de adequação descritiva e empírica. A questão que levanto é que qualquer que seja a teoria, postulá-la para o PB como um todo pode deixar de lado questões significativas da sócio-história que caracteriza essa língua, além de, insisto, cair no equívoco da homogeneidade do PB. Por outro lado, não é desejável que se instaure uma cisão do PB em n-taxonomias, mas é pertinente que o 'olhemos' a partir de uma perspectiva de continuum de portugueses.

\subsubsection{Sobre a história do continuum de português}

A literatura sobre o português falado no Brasil, como já mencionei anteriormente, faz distinção entre um português standard, que tem sido identificado pela sigla PB, e o português 'popular' ou 'vernacular', identificado pela sigla PVB. Essa situação tem ganhado destaque, principalmente no quadro da sociolinguística brasileira. A variação que se manifesta nessas duas variedades de português vem sendo denominada por Lucchesi (2002, 2006, 2009) de “polarização sociolinguística do Brasil”. 
Uma proposta interessante no sentido de entender tal polarização, é a ideia de estudá-la a partir de um continuum. Bortoni-Ricardo (1985), ao considerar a situação soliolinguística vigente no país, alega que é atraente a ideia de expor as variedades em um ‘espectro hipotético' que vai desde o vernáculo rural até o padrão urbano das classes superiores:

\begin{abstract}
Although it cannot be treated as a post-creole cotinuum we are attracted to the idea of displaying the varieties on a hypothetical spectrum ranging from the isolated rural vernacular at one extreme to the urban standard of the upper classes at the other. A crucial distinction that must be made then is between the features that show a gradient stratification along the continuum and those that indicate a sharp stratification between rural and urban speech. ${ }^{32}$
\end{abstract}

(BORTONI-RICARDO, 1985, p. 246)

Seguindo a ideia do continuum, Mello (1996) propôs em sua tese um continuum dialetal para as variedades que compreendem o português brasileiro:

The vernacular language spoken in Brazil today can be represented by a continuum extending from a partially restructured variety of Portuguese spoken by uneducated people at one extreme (especially in rural, isolated areas, e.g. Helvécia Portuguese) to a near standard BP spoken by urban populations at the other (cf. Guy 1981, Holm 1987). ${ }^{33}$

(MELLO, 1996, p. 106)

Mello (op. cit. p. 19) observa a estratificação que se manifesta no continuum dialetal que configura o PVB: "[...] o PVB refere-se às variedades de língua faladas pela maior parte da população analfabeta ou quase analfabeta rural e, geralmente, por pessoas urbanas pertencentes aos estratos sociais mais baixos no Brasil".

Mello (1996) define o PVB como um continuum de dialetos. Assim, as variedades de PVB mais divergentes do PB são as que se encontram em uma das extremidades do continuиm e que são faladas em comunidades afrobrasileiras que, aparentemente, têm sido consideradas comunidades isoladas, que sofrem menos pressão que os dialetos mais padronizados.

\footnotetext{
32 Tradução aproximada: "Embora não possa ser tratado como um cotinuum pós-crioulo [a situação sociolinguística no Brasil] somos atraídos pela ideia de mostrar as variedades em um espectro hipotético que vai do vernáculo rural isolado, em um extremo, ao padrão urbano das classes superiores em outro. A distinção crucial que deve ser feita, então, é entre as características que mostram uma estratificação gradativa ao longo do continuиm e aquelas que indicam uma estratificação nítida entre o discurso rural e o urbano".

${ }^{33}$ Tradução aproximada: "A língua vernacular falada hoje no Brasil pode ser representada por um contínuum que se estende a partir de uma variedade de português parcialmente reestruturada e falada por pessoas sem educação formal em um extremo (especialmente em áreas rurais, isoladas - por exemplo, o português de Helvécia), a uma variedade próxima do português brasileiro padrão, falada por populações urbanas no outro extremo (cf. Guy 1981; Holm, 1987)".
} 
Outro estudo que merece menção, já apontado na seção anterior, é o de Petter (2008). Diferentemente de Mello (1996), Petter propõe a ideia do continuum entre as variedades de português brasileiro e as faladas na África, alargando as possibilidades de cotejo de PB ou mesmo PVB não mais com o PE (como normalmente se tem feito). Petter investiga a identidade do PB, apresentando uma proposta nova de análise: considerar essa variedade linguística como parte de um conjunto mais amplo, que inclui o português angolano (PA) e o português moçambicano (PM). A autora propõe a necessidade de se implementar um estudo na direção da compreensão do continuum afro-brasileiro do português. Assim, o cotejo deixa de ser apenas com o PE e passa a ser feito com outras variedades de português.

Petter constroi sua tese a partir dos seguintes argumentos:

(i) uma característica comum às variedades de português angolana (PA) e moçambicana (PM) é o fato de não se terem desenvolvido como línguas crioulas, além de que, atualmente, em Angola e em Moçambique ainda são faladas línguas africanas do grupo banto, cujo contato com o português oferece um rico ambiente para cotejá-las sincronicamente;

(ii) as situações particulares de contato linguístico promoveram as semelhanças entre as variedades de português faladas em Angola, no Brasil e em Moçambique (em épocas diversas, mas envolvendo o português e um conjunto de línguas muito próximas, as do grupo banto), produzindo resultados semelhantes nos níveis lexical e morfossintático, permitindo defender a existência de um continuum afro-brasileiro de português;

(iii) reconhece que não existem entidades homogêneas identificáveis como "português africano", "português moçambicano", "português angolano" ou "português brasileiro"; a história do contato e os aspectos linguísticos comuns a essas variedades autorizam a levantar a hipótese do continuum, que deriva de uma origem comum: a expansão da língua portuguesa num contexto de colonização.

(iv) considera que, assim como o continuum de línguas românicas, o continuum das variedades de português resulta de uma "mistura" de línguas locais com uma língua dominadora comum.

(v) deixa claro que há uma ecologia linguística particular a cada um dos três países, evidenciada pelo multilinguismo dos falantes africanos, usuários de 
línguas do grupo banto, pela diversidade das línguas em presença no Brasil (línguas africanas (sudanesas e banto), línguas indígenas e de imigrantes);

o momento histórico distinto do contato e recontato com o português (século XVI e final do século XIX em Angola e Moçambique, quando realmente se deu a colonização portuguesa). Desse contexto decorre um estatuto linguístico específico para a língua portuguesa em cada território onde ela é falada, que não impede, no entanto, a existência de um continuum entre as variedades linguísticas selecionadas;

(vii) a comunicação entre Brasil e Angola, desde o final do século XVI, quando os 'brasílicos' passam a negociar diretamente com a África, como um outro fator que contribuiu para o contato.

\subsubsection{Uma proposta de continuum para o português de Jurussaca}

A partir das propostas apresentadas na seção anterior sobre a proposição de estudo do português brasileiro dentro de um continuum, nesta subseção argumento em favor do continuum de português e da acepção de contato linguístico para o estudo da sintaxe pronominal da comunidade quilombola de Jurussaca, proposta central desta tese.

Como mencionado anteriormente, a sigla PB não é suficiente para abrigar todas as variedades de falares que se observam em um país com dimensões geográficas, históricas, culturais e sociais bastante diferentes como o Brasil. A referida sigla acaba por ficar restrita à modalidade escrita da língua e aproximada daquela falada pelas pessoas de maior escolaridade, oriundas das classes sociais mais abastadas, deixando o restante da população a expressiva maioria, por sinal -, fora de seu âmbito. A literatura que trata das modalidades não standard, normalmente estão abrigadas sobre a sigla PVB - português vernacular brasileiro. O PVB compreende a variedade de português falada pelas comunidades que se desenvolveram longe dos centros urbanos e, portanto, sem o contato com a 'norma culta' ou 'norma de prestígio'.

A região Norte, que compreende toda a Amazônia brasileira, tem peculiaridades geográficas e demográficas distintas das do restante do país. No Estado do Pará, situado na região Norte, por exemplo, a ocupação histórico-territorial teve, de um lado, a concentração de europeus, majoritariamente portugueses, na capital - Belém - e, de outro, a ocupação do 
interior a partir do curso dos rios com a formação de comunidades, muitas delas mistas, de matriz indígena e africana, como as comunidades quilombolas ${ }^{34}$. Mais recentemente, na segunda metade do século XX, com a construção das estradas, ocorreu um denso fenômeno de migração de populações oriundas de todas as regiões do país para o interior, não apenas do Estado do Pará, mas de toda a região amazônica.

Ao analisar o português de Jurussaca, comunidade localizada na região nordeste do Estado do Pará, pretendo tomá-lo como parte do continuum de português brasileiro, inserindo a variedade falada na comunidade numa localização do continuum em que se correlaciona com o português afro-brasileiro e o indígena. Nesse sentido, sigo as propostas de estudo de variedades a partir do continuum de português vigente no Brasil (cf. Mello, 1996; Petter, 2008).

Ao se estudar variedades populares ou afro-brasileiras como a de comunidades quilombolas, não se pode deixar de considerar o que esses falares têm em comum. Pagotto (2007) chamou a atenção para esse fato, quanto à 'unidade do Português brasileiro', pois, para Pagotto, são os falares populares das mais diversas regiões os mais interessantes de se observar quanto ao traço 'união'. Em Jurussaca não é diferente. Mas faz-se necessário destacar que, no que se refere à observação de Pagotto(op. cit. p. 469): "não se tem notícia de dialetos populares que façam uso do clítico acusativo", nela está implícito que o autor se refere aos clíticos de terceira pessoa (o/a; os/as; lhe/lhes), pois, como é sabido, os clíticos acusativos de primeira e segunda pessoas são largamente utilizados nos dialetos populares, como, por exemplo: eи me machuquei; еи te/lhe amo. Para além dessas construções, em alguns dialetos populares, registram-se, também, o uso de formas acusativas não clíticas: $e u$ machuquei eu; еи amo tu/você. Formas que na variedade de Jurussaca ocorrem em contexto de variação com os clíticos de primeira e segunda pessoas, confirmando a 'unidade' de dialetos populares, conforme Pagotto (op. cit.) e que motiva buscar um cotejo do conjunto de variedades entre a fala de Jurussaca com o seu entorno e com a variedade popular brasileira de modo geral.

Petter \& Oliveira (2012, subseção 1.1.) advogam uma subdivisão geográfica do continuum dialetal de Mello (1996). As autoras propõem um continuum para as regiões de Minas Gerais e Pará, como se vê a seguir:

\footnotetext{
${ }^{34}$ Sobre comunidades quilombolas, ver: NAEA (2005). Quilombos do Pará, Cd-rom. Belém: NAEA-UFPA \& Programa Raízes. De acordo com o NAEA - Núcleo de Altos Estudos da Amazônia - o Estado do Pará possui 253 povoados quilombolas. As áreas quilombolas do Pará foram delimitadas pelo NAEA a partir de macroregiões do Estado.
} 
(1) Contínuo Dialetal Português Vernacular Brasileiro de Minas Gerais - PVBMG

(português afro-brasileiro) / (falares regionais) / (falares urbanos não-padrão)

Ex. Milho Verde; Tabatinga/ ex.: 'Triângulo Mineiro' / ex.: BH não-padrão

(2) Contínuo Dialetal Português Vernacular Brasileiro do Pará - PVBP

(português afro-brasileiro) /(falares regionais) / (falares urbanos não-padrão)

Ex. Jurussaca / ex.: fala dos ribeirinhos / ex.: belenense 'não culto'

Em (1) - PVBMG -, o português falado pelas comunidades de Milho Verde e Tabatinga (foco deste trabalho) tipificam a subvariedade afrobrasileira desse contínuo que apresenta distinções das outras subvariedades: (a) a regional, em que se localizam os falares regionais como os da zona da mata mineira e (b) a dos falares urbanos não-padrão como o português nãoculto de grandes centros urbanos mineiros como a capital, Belo Horizonte, ou Juiz de Fora, por exemplo. Em (2) - PVBP -, o português falado pela comunidade de Jurussaca (também foco deste trabalho) tipifica a subvariedade afro-brasileira do contínuo que apresenta distinções das outras subvariedades: (a) a regional, em que se localizam os falares regionais como os diferentes falares ribeirinhos e (b) os falares urbanos não-padrão como o da capital, Belém, ou Altamira, por exemplo.

(PETTER \& OLIVEIRA, 2012, p. 4)

Na subseção a seguir, retomo o continuum dialetal proposto por Petter \& Oliveira e o amplio, no sentido de contemplar as variedades [+/- marcadas].

\subsection{O Português Afro-Indígena}

Nesta subseção advogo em favor do conceito 'português afro-indígena' proposto por Oliveira et alii (no prelo). Os autores defendem o afro-indígena no contexto que inclui as variedades de português popular faladas no Brasil em comunidades rurais que conservam especificidades etnolinguísticas e que "se localizam" dentro de um continuum de variedades de português brasileiro [+marcadas], como o português afro-brasileiro e o indígena. Assumem que o afro-indígena detém características de língua "parcialmente reestruturada" com base em abordagens da morfossintaxe e em questões voltadas à morforfologia territorial da comunidade. Os autores assim definem o conceito afro-indígena: 
Uma variedade vernacular rural de português brasileiro $L_{1}$ falada por comunidades envoltas em miscigenação afro-indígena, mas que selecionam politicamente o termo "afro" ou "indígena". Exemplificam-se as comunidades de Jurussaca/PA (autoidentificada como comunidade quilombola, logo "afro") e Almofala-Tremembé/CE (autoidentificada como comunidade indígena, mas não "afro").

Além da característica de "português $\mathrm{L}_{1}$ ", o português afro-indígena atesta as seguintes outras características: (i) festas de sincretismo religioso que se subdividem em dois subtipos: (a) subtipo "ladainhas" ("Jurussaca"); (b) subtipo "torém/torén" ("Almofala/Tremembé"); (ii) linguagens cerimoniais (ex.: ladainhas; a música cantada na dança do torém/torén).

A variedade de português afro-indígena compartilha com as variedades de português afro-brasileira e indígena a característica de localizarem-se ao extremo [+ Marcado] do continuum dialetal de português; ao mesmo tempo que difere da variedade indígena, $\mathrm{L}_{2}$ por definição, e da afro-brasileira, que não contempla o traço de miscigenação indígena. ${ }^{35}$

(OLIVEIRA et alii (no prelo)

Assim, proponho que o Continuum Dialetal de Português deve abarcar o português afro-indígena, compartilhando, em conjunto com o português afro-brasileiro e o indígena, o locus das variedades [+ Marcadas] nesse continuum.

Figura 2 - Continuum de português brasileiro

\section{O Continuum de Português Falado no Brasil}

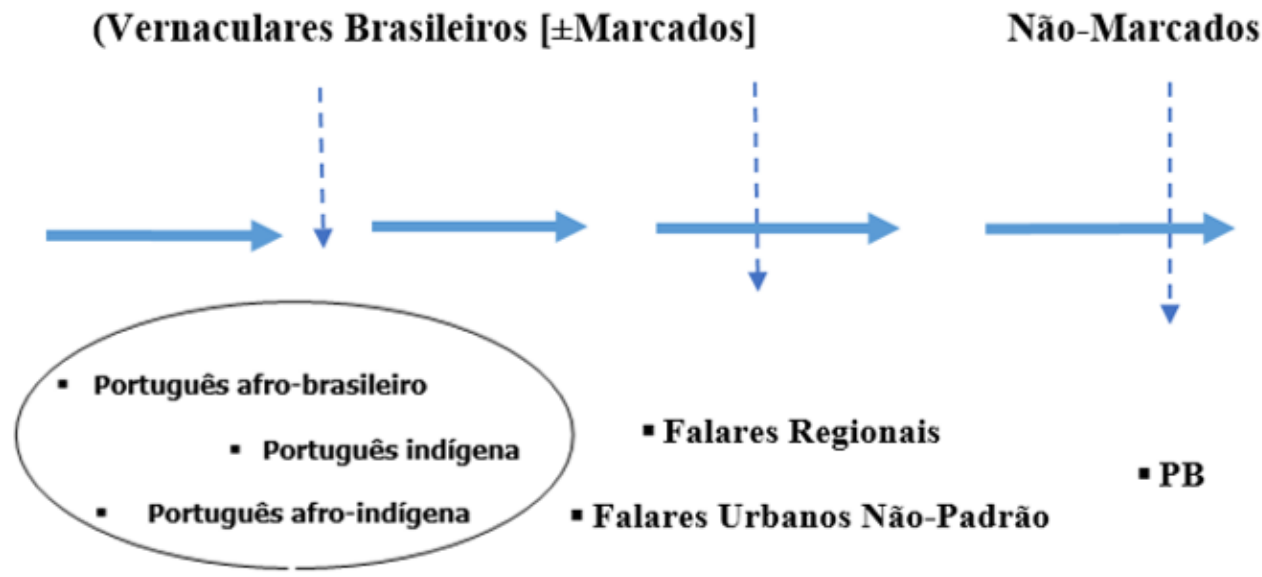

\footnotetext{
${ }^{35}$ Em nota Oliveira et alii (no prelo) explicam que: "As festas de sincretismo e as linguagens cerimoniais estão intimamente relacionadas no português afro-indígena. Atente-se que as "cerimônias" realizadas nessas comunidades rurais brasileiras são paralelas e compatíveis, porém independentes das realizadas pelo sacerdote da igreja católica. Este mesmo fato foi atestado para a comunidade de Ano Bom - ver Araujo et al (2013: 28) o que une consideravelmente o "mundo" do contato Atlântico e, em particular, essas comunidades sob enfoque".
} 
Nesta tese esse continuum é de grande relevância não apenas pelas quetões já advogadas anteriormente, mas também para as análise do sistema pronominal de Jurussaca, se comparado a uma área vizinha - as cidades de Bragança e Tracuateua, pois a variedade afro-indígena [+marcada], ao ser comparada à variedade de Bragança/PA [-marcada], apresenta especificidades. No capítulo 3 retomo essa questão.

Logo, os estudos sobre PVB não definem essa variedade como uma unidade, mas como um conjunto de variedades, dialogando com o que aponta Pagotto (2009, p, 469) para as variedades populares - 'o conjunto de características comuns'. Assim, um cotejo do sistema pronominal das variedades [+marcadas], contidas no círculo (à esquerda do continuum), certamente, evidenciaria um 'conjunto de características comuns', mencionadas por Pagotto - a ausência de pronomes clíticos acusativos e dativos de terceira pessoa pode ser tomada como um exemplo.

Por fim, em consonância às possíveis situações de contato por que passou a comunidade de Jurussaca, o quadro dos pronomes pessoais que será apresentado no capítulo 3 desta tese, não será tomado dentro de abordagens que apontam para casos de 'recategorização'. Defendo que as especificidades que ocorrem ali sejam tratadas como um processo mais complexo de 'reestruturação da gramática' em função do contato etnolinguístico e não de situações discursivas pontuais (Cf. Oliveira \& Figueiredo, no prelo).

\subsection{Considerações sobre a mudança linguística face às relações de contato entre línguas}

Nesta seção faço, brevemente, algumas considerações relativamente à compreesão do termo contato linguístico. Kroch (2001, p. 4) coloca uma primeira questão sobre a suceptibilidade das línguas em apresentarem variações e/ou mudanças: (i) as línguas são estáveis ou instáveis por natureza; isto é, deixando de lado os efeitos do contato lingüístico e outras formas de mudança social, deveríamos esperar que as línguas manifestem mudança ou estabilidade? E subjacente a esta questão, estão duas teses: (ii) as mudanças linguísticas são exógenas ou endógenas. Sobre os fatores endógenos há a tese da deriva linguística; sobre os fatores exógenos ou externos, a tese do contato linguístico. Portanto, interessa aqui discutir esses fatores exógenos aos quais se refere Kroch.

Segundo Kroch, uma força atuante para a mudança sintática cuja existência não pode ser duvidada é o contato linguístico. O contato pode levar ao empréstimo de traços sintáticos ou levar à perda de traços que distinguem as línguas em contato, o que pode ter 
acontecido, por exemplo, para a marcação de Caso em anglo-saxão que esteve em contato com o escandinavo (op. cit. p. 4).

O contato linguístico é um fator, portanto, externo à língua e pode ser visto como elemento desencadeador de diferentes processos. Entre os linguistas brasileiros tem havido mais de um enfoque teórico para explicar as questões que estão por trás dos processos de mudança no PB face às relações de contato. Dentro da tradição estruturalista, as mudanças ocorridas em uma dada língua, se analisadas sob o enfoque do contato linguístico, como no caso do PB, pode ser a explicação de mudanças resultantes de uma deriva secular da língua, acelerada por fatores externos como contato (cf. Naro \& Scherre (1993, 2007). Sob o escopo mentalista da teoria gerativa, o termo variação é um pouco mais complexo: a princípio, uma gramática não deve gerar estruturas em variação, ao contrário, a variação seria o reflexo de diferentes estruturas geradas por diferentes gramáticas (Paixão de Souza, 2006) ${ }^{36}$. Assim, para a compreensão dos diferentes padrões de colocação pronominal ênclise $v s$. próclise nas variedades contemporâneas de língua portuguesa, dentro do escopo da teoria gerativa, não há espaço para a postulação de variação de colocação pronominal, mas sim diferentes padrões de colocação ou diferentes gramáticas que geram diferentes estruturas licenciadas por operações sintáticas específicas.

Para Paixão de Souza (2006), a mudança linguística pode ser uma noção desafiadora a depender da concepção de linguagem; é o caso do quadro teórico mentalistachomskiano:

Para a concepção da lingüística histórica tradicional, como vimos, é central a evidência de que as línguas mudam. Pois se testemunhamos diferenças entre etapas cronológicas que se sucedem; e se concebemos os eventos da língua como orgânicos, a diferença entre as etapas só pode ser conceituada como desenvolvimento ou evolução. Entretanto, a perspectiva estruturalista de sistema rejeita a noção de organicidade - ou seja, cada sistema tem sua própria lógica, independente da lógica do sistema que o precede cronologicamente. Nesse quadro, fundou-se um objeto-língua que não muda naquele sentido orgânico - pois é um objeto que só tem sentido analítico na estaticidade. A rejeição da perspectiva estruturalista, nos meados do século XX, remeterá por sua vez a outros deslocamentos do foco de análise. No caso da fundação da perspectiva mentalistachomskiana, o objeto-língua constrói-se novamente no plano do estável: neste caso, a estabilidade abstrata de uma capacidade mental. A faculdade da linguagem, essa capacidade mental, é portanto novamente um objetolíngua que não comporta a noção de mudança em sentido orgânico - ou seja, não evolui, não se transforma, não se desenvolve.

(PAIXÃO DE SOUZA, 2006, p. 39)

\footnotetext{
${ }^{36}$ Dentro do quadro gerativo, há outras abordagens sobre mudança linguística (cf. LIGHTFOOT, 1999) mas encontram-se for a do escopo deste trabalho.
} 
Por fim, diversos trabalhos diacrônicos no Brasil assumiram como hipótese as propostas de Tarallo \& Kato $(1987,1989)$ do estudo da variação trans-linguística (sobre parâmetros de variação entre as línguas) aliado à variação intra-linguística (com base na metodologia sociolinguística) a partir da hipótese de que os mesmos mecanismos estariam em jogo nos processos que resultam em mudança. Nesses trabalhos, a frequência de uso em construções com clíticos em português, por exemplo, pode ser estudada ao lado das hipósteses sobre as operações gramaticais que licenciam esses elementos - em que tanto ênclise quanto próclise resultam das operações de Merge e Agree empregadas aos traços formais não valorados durante a derivação.

\subsection{Síntese do capítulo}

Neste capítulo foi discutida a história do português brasileiro a partir do viés do contato linguístico que a língua portuguesa teve com as línguas dos vários povos que compõem historicamente a sociedade brasileira. Ao longo de sua história, o português brasileiro afastou-se significamente da variante portuguesa e nas últimas décadas do século passado, principalmente no âmbito da teoria gerativa e da sociolinguística, um número significativo de publicações contribuiu para que a tese da gramática 'independente' do PB fosse fortemente discutida e, normalmente, aceita. O preconceito linguístico, no entanto não diminuiu, mas como mostram as pesquisas, paulatinamente, os brasileiros têm feito cada vez mais uso de formas condenadas pela tradição prescritiva como no caso dos pronomes e até mesmo das relativas cortadoras.

Nesse sentido, procurei mostrar os esforços positivos empreendidos pela linguística brasileira para que o termo PB assumisse o status que tem atualmente e as contribuições que isso trouxe em termos da descontrução de preconceitos em torno da variedade de português falada pelos brasileiros; ao mesmo tempo busquei explorar as consequências que afloraram dessa prerrogativa: (i) o PB passou a representar a fala dos brasileiros homogeneamente, e (ii) a tese do continuum de português, que mostra que as variedades brasileiras vão de um extremo [+marcado] ao outro [não-marcado], ao mesmo tempo que estão ligadas entre si, não apenas sob a dimensão da variação dialetal (ligada à dimensão social), mas às questões de sua própria gênese. 


\section{CAPÍtulo II}

O estatuto das formas pronominais tônicas e clíticas abordagens clássica e formal

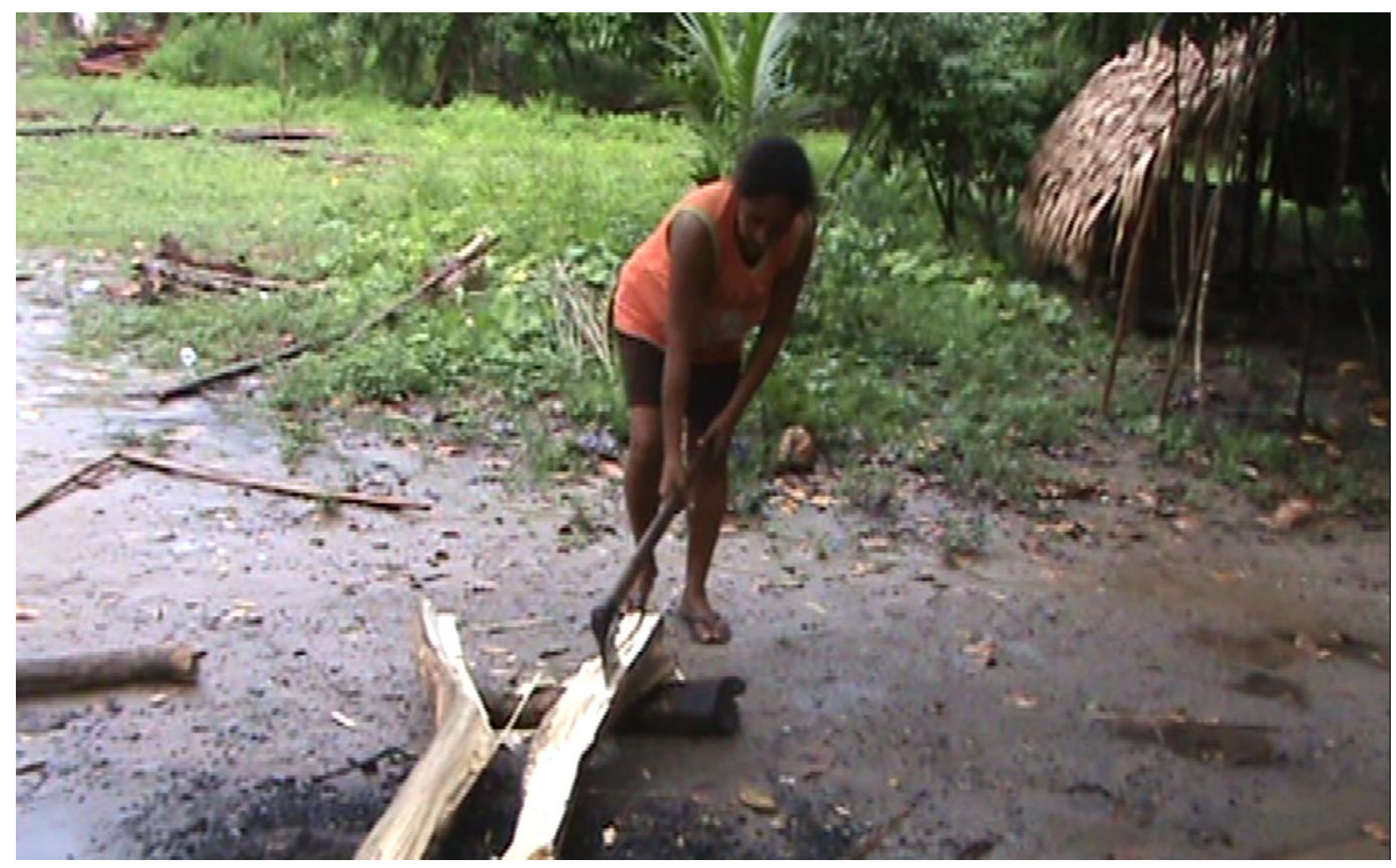




\subsection{Introdução}

Neste capítulo busco definir conceitualmente a categoria 'pronome pessoal' e para fazê-lo, parto dos estudos clássicos sobre a expressão pronominal, com a apresentação do 'quadro pronominal pessoal' presente nas gramáticas de língua portuguesa, mas sem me pautar exclusivamente na descrição clássica da Gramática Tradicional; faço a ela algumas referências, quando necessário. Menciono, por outro lado, a Gramática de Língua Portuguesa de Mateus et alii (2003), cuja abordagem é 'mais linguística', passando por Câmara Jr. (1972), sobre o estudo dos vocábulos formais. Parto, então, desse percurso para chegar à noção mais refinada de pronome que se desenvolveu dentro dos modelos teóricos de Regência e Ligação e Princípios e Parâmetros a partir das duas últimas décadas do século passado, chegando ao modelo atual da teoria, o modelo minimalista.

Justifico a minha opção pela escolha de um quadro teórico formal por entender que as peculiaridades configuracionais do item pronome pessoal, escopo central desta tese, requerem 'ferramentas' que permitam investigar melhor as suas possibilidades morfossintáticas e semânticas relativamente à forma, à colocação, à referencialidade etc. A possibilidade de colocação, aliás, é um dos itens mais instigantes e investigá-la do ponto de vista configuracional passa pela compreensão da amplitude e das especificidades dessa categoria e, a meu ver, pela escolha do quadro teórico que disponibiliza um 'equipamento' mais completo para a análise das possibilidades estruturais de colocação pronominal clítica, muito relevante para um dos objetivos que pretendo seguir nesta tese (capítulo 3). Um deles está diretamente ligado à temática da colocação em que buscarei compreender e explicar o estatuto do item 'nós' em construções como "ele nós ajudou" comuns e corriqueiras na fala da comunidade de Jurussaca, mas muito intrigante, para mim, do ponto de vista composicional e configuracional daquela pro-forma cuja possibilidade em ser um NP ou um $\mathrm{N}^{0}$, aliás, extrapola os recursos da sintaxe, passando pela interface prosódica.

Neste capítulo, optei, portanto, por explorar conceitualmente a definição pronominal relativamente às possibilidades semânticas e sintáticas da referencialidade e da colocação dos itens pronominais que permeiam o quadro teórico de Regência e Ligação e sua atualização em Princípios e Parâmetros (Chomsky, 1981, 1986) bem como as noções de C-comando e seus princípios norteadores $A, B$ e $C$.

Estudos sintáticos como os de Kayne $(1975,1991)$ lançaram luzes ao estatuto dos pronominais clíticos e se tornaram referência para estudos e propostas de análise dos 
pronominais em línguas românicas, assim como outros trabalhos que vieram mais tarde, como: Uriagereka (1992, 1995), Martins (1994), Cardinaletti \& Stake (1999), Raposo (2000), Galves (2001, 2002), Duarte \& Matos (2000), Brito, Duarte \& Matos (2003), Duarte, Matos $\&$ Gonçalves (2005), entre outros, são fundamentais para mim como fonte de pesquisa e de inspiração para a construção desta tese.

\subsection{Noções iniciais das categorias pronominais}

Nas gramáticas de língua portuguesa, os quadros pronominais apresentados, normalmente, baseiam-se na forma dos pronomes quanto à função gramatical que eles expressam, isto é, a função sujeito, representada pelas formas pronominais do caso reto e as funções completivas direta e indireta, representadas pelos chamados átonos e tônicos preposicionados ou oblíquos. Uma curiosidade observada pelas gramáticas de língua portuguesa é o fato de os pronomes conservarem em suas formas o resquício da morfologia de caso que existia no latim, a exemplo as formas $e u, m e$, mim relativamente ao sujeito (caso nominativo) e aos objetos direto e indireto (casos acusativo e dativo) - mantida também nas línguas românicas como um todo - mas com forte variação nas variedades brasileiras de português, pois, como é sabido, o quadro pronominal descrito nas gramáticas apresenta uma relação assimétrica com o uso que os brasileiros fazem dos pronomes. A título de exemplo, vejamos o quadro abaixo, retirado de Bechara (2009).

\begin{tabular}{|c|c|c|c|c|}
\hline \multirow{2}{*}{\multicolumn{3}{|c|}{ PRONOMES PESSOAIS RETOS }} & \multicolumn{2}{|c|}{ PRONOMES PESSOAIS OBLÍQUOS } \\
\hline & & & Átonos & Tônicos \\
\hline \multirow{3}{*}{ Singular } & $1^{\mathrm{a}} \cdot \mathrm{p}$ & $e u$ & $m e$ & $\operatorname{mim}$ \\
\hline & $2^{\mathrm{a}} \cdot \mathrm{p}$ & tu & te & $t i$ \\
\hline & $3^{\mathrm{a}} \cdot \mathrm{p}$ & ele, ela & lhe, o, a, se & ele, ela, si \\
\hline \multirow{3}{*}{ Plural } & $1^{\mathrm{a}} \cdot \mathrm{p}$ & nós & nos & nós \\
\hline & $2^{\mathrm{a}} \cdot \mathrm{p}$ & vós & vos & vós \\
\hline & $3^{\mathrm{a}} \cdot \mathrm{p}$ & eles, elas & lhes, os, as, se & eles, elas, si \\
\hline
\end{tabular}

Quadro extraído de Bechara (2009, p. 164)

37 A NGB - Nomenclatura Gramatical Brasileira -, foi implementada em 1959, por meio de portaria ministerial. O conceito da NGB liga-se ao conjunto dos vocábulos estabelecidos para uso na gramática cujo objetivo é padronizar a nomenclatura gramatical em uso nas escolas e na literatura didática. 
Por outro lado, há estudos mais recentes que seguem a tendência de abordagem dos aspectos gramaticais do português brasileiro na perspectiva da oralidade e que, mesmo compreendido como expressão da 'norma culta' dos brasileiros, a expressão pronominal também é assimétrica em relação ao português dito standard, apresentado no quadro acima. Um bom exemplo disto, é o quadro dos pronomes em Perini (2010): ${ }^{38}$

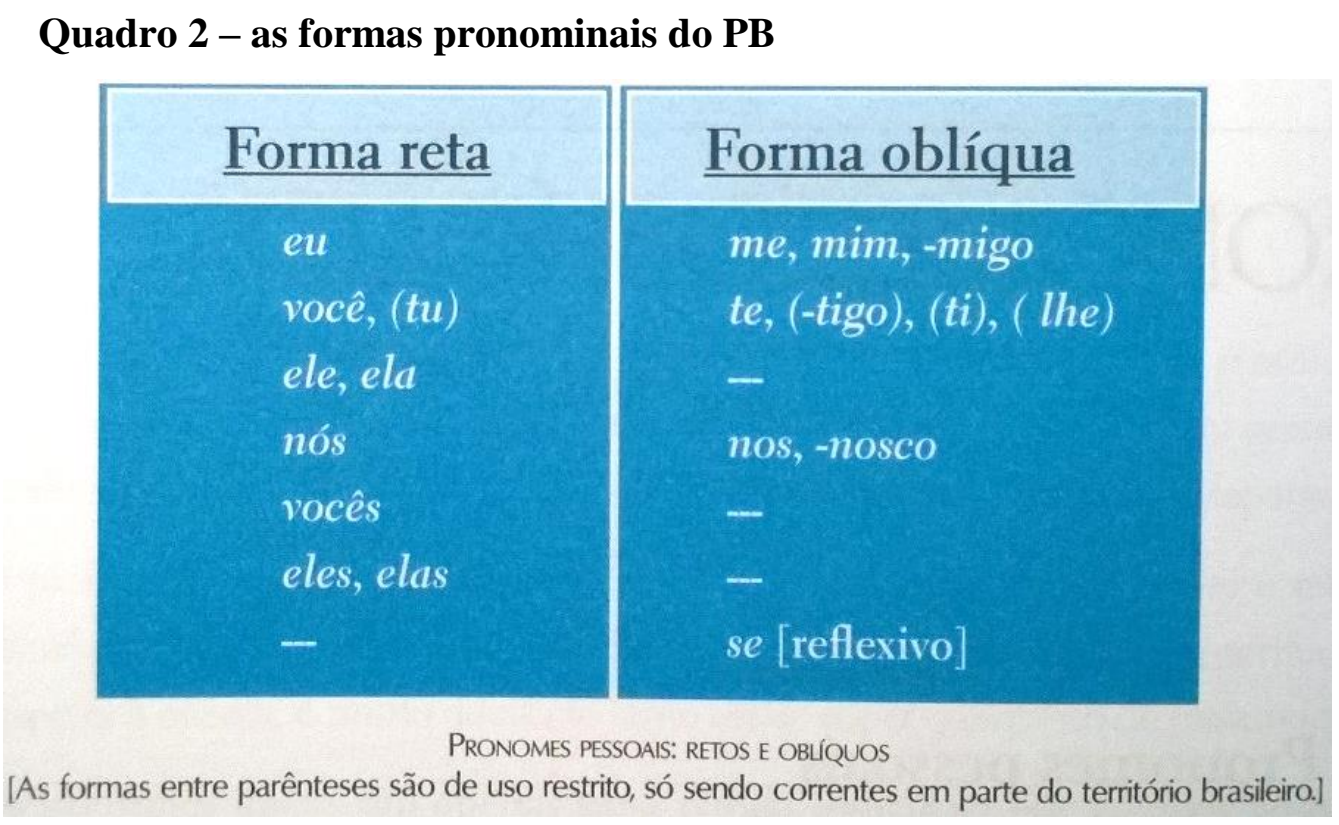

Quadro extraído de Perini (2010, p. 116)

É significativa a assimetria resultante da forma e função entre os pronominais do primeiro quadro (Bechara, 2009) e os do quadro do português brasileiro (culto) de Perini (2010): com a ausência dos clíticos de terceira pessoa ( $o$, $a$, lhe e flexões) na coluna 'Forma Oblíqua', assim como a inserção de 'lhe' como pronome de segunda pessoa. Desse modo, Perini assume as formas retas como as únicas disponíveis para preencherem as funções gramaticais acusativa e dativa de terceira pessoa.

As assimetrias observadas nos quadros acima refletem o uso que os brasileiros fazem dos itens pronominais, bem distante dos pronomes elencados pela Norma Gramatical Brasileira. Tais assimetrias ocorrem não apenas com os pronomes do caso sujeito relativamente à $2^{\mathrm{a}}$. pessoa do singular e do plural, mas, principalmente, em relação aos pronomes pessoais oblíquos. Nas variedades populares de português brasileiro, ou em

\footnotetext{
${ }^{38}$ Há também outras gramáticas atuais que enfocam o português brasileiro, a exemplo a Gramática Pedagógica do Português Brasileiro (Bagno, 2011), a Gramática do Português Brasileiro (Castilho, 2010) e a Pequena Gramática do Português Brasileiro (Castilho \& Elias, 2012).
} 
comunidades como as quilombolas, somente os pronomes referentes à $1^{\mathrm{a}}$. e $2^{\mathrm{a}}$. pessoas do singular (e com variações) serão semelhantes ao quadro 1 (BECHARA, 2009).

Muitas hipóteses já foram levantadas na busca da compreensão dos fenômenos que estão por trás da redução do quadro pronominal do português brasileiro. Ao iniciar este capítulo, em que apresento os quadros que refletem essas diferenças, não tenciono discuti-las ou refutá-las, mas evidenciá-las. Inicio uma apresentação do item pronominal, buscando o seu conceito desde a sua classificação tradicional, ou clássica, chegando às mais recentes.

A categoria pronominal tem sido classificada tradicionalmente por traços binários e se dentro do paradigma da tradição normativa esses traços assumem valores binariamente opostos, quer sintaticamente com formas pronominais retas $v s$ formas oblíquas e as suas respectivas funções sujeito vs. complemento; quer fonologicamente, com formas tônicas $v s$. formas átonas; dentro do quadro teórico formal, a categoria pronominal (composta por traços $\varphi$ - pessoa, gênero e número - e também regida por Caso) institui outros critérios de oposições também binários, como positivo vs. negativo. Diversos estudos, no entanto, têm mostrado que essa oposição binária não permite uma descrição acurada de todos os fenômenos da categoria pronominal nas línguas. Logo, surgem outras propostas como a tripartição pronominal (Cardinaletti \& Starke, 1999), a geometria de $\operatorname{traços}^{39}$ (Harley \& Ritter, 2002), entre outras; porém nenhuma delas é definitiva, dadas as especificidades da categoria em pauta.

A emergência da classificação desses fenômenos ligados à categoria pronominal é, pois, um dos fatores de grande relevância no estudo das línguas. Tais discussões serão retomadas adiante; na sequência, passo a uma breve introdução da categoria pronominal relativamente ao português.

Não parece ser exagerado dizer que qualquer estudo sobre o quadro pronominal do português brasileiro abordará, ainda que indiretamente, o estudo clássico dos vocábulos proposto por Câmara Jr. (1996[1970], p. 69,70). Os estudos de Câmara Jr. incluem às formas livres e presas descritas por Bloomfield (1933), as formas dependentes. Câmara Jr. (op. cit.) inclui a essa nova categoria de formas - dependentes - aquelas que não são livres como os vocábulos nem presas como os afixos; mas apenas se adjungem a outro vocábulo como o artigo, certas preposições e certos pronomes que, por serem de natureza clítica, são

\footnotetext{
39 A geometria de traços também apresenta parâmetros binários, porém para um conjunto diversificado de traços.
} 
integrados a um vocábulo maior e subordinado ao acento que dá individualidade fonética a esse vocábulo.

Naquela classificação de Câmara Jr, os pronomes pessoais em língua portuguesa foram distribuídos 'binariamente' em formas livres: os pronomes tônicos; e formas dependentes: os clíticos ou átonos, na preferência das gramáticas.

Câmara Jr. (1996[1970]), sobre a classificação dos vocábulos formais, afirma que:

Há, em princípio, três critérios para classificar os vocábulos formais de uma língua. Um é o que eles, de maneira geral, significam do ponto de vista do universo biossocial que se incorporam na língua; é o critério semântico. Outro, de natureza formal ou mórfica, se baseia em propriedades de forma gramatical que podem apresentar. Um terceiro critério, que teve muita acolhida na gramática descritiva norte-americana, orientada pela linguística sincrônica de Bloomfield, é o funcional, ou seja, a função ou papel que cabe ao vocábulo na sentença.

(CÂMARA JR., 1996, p. 77)

Quanto aos critérios a que se refere Câmara Jr (1996), eles são também captados pela noção tradicional corrente nas gramáticas de língua portuguesa para os pronomes pessoais. São classificados, por exemplo, a partir de critérios sintáticos, como: (i) distribuição e função sintática equivalente a dos elementos nominais: "os pronomes desempenham na oração as funções equivalentes às exercidas pelos elementos nominais" (Cunha \& Cintra, 1985 p. 268); (ii) pela sua forma, por serem retos ou oblíquos (Cf. Cunha \& Cintra, 1985, p. 269) e (iii) e semanticamente, por denotarem as três pessoas gramaticais (op. cit. p. 269).

Câmara Jr. (1996) informa, também, que o que distingue os pronomes de maneira geral, são três noções gramaticais que se encontram neles, mas não nos nomes, a saber: (i) a noção de pessoa gramatical, (ii) noção gramatical própria dos pronomes, existente em vários deles, de um gênero neutro em função substantiva, quando a referência é a coisas inanimadas: isto, isso, aquilo e formas específicas para seres humanos: alguém, ninguém e outrem, e (iii) a categoria de casos - noção gramatical privativa dos pronomes. Câmara Jr (op. cit. p. 85) explica, ainda, que essas três noções gramaticais características dos pronomes não entram no mecanismo flexional da língua portuguesa e são expressas lexicalmente por mudança de vocábulo. ${ }^{40}$

\footnotetext{
${ }^{40}$ Sobre esse aspecto, as noções formais da categoria pronominal divergem da de Câmara Jr. no sentido de as 'noções gramaticais' dos pronomes serem expressas lexicalmente. No quadro teórico formal, essas noções não são universalmente lexicais mas definidas por traços phi. Não sendo os pronomes compreendidos como primitivos lexicais, mas elementos 'valorados' durante a numeração de uma dada frase. A noção formal das categorias lexicais passou a considerar apenas os elementos categorias nome, verbo, preposição e adjetivo
} 
É interessante observar que são as formas dependentes propostas por Câmara Jr. motivo de muita investigação dentro do modelo teórico formal, resultando numa quantidade robusta de trabalhos nos últimos anos. Tais trabalhos analisam desde o comportamento dessas formas nas línguas românicas, o qual não é idêntico, ao seu comportamento, em geral, nas línguas do mundo (e varia bastante, também, dentro das línguas românicas). Somente para citar alguns desses trabalhos: Kayne (1975, 1991), Uriagereka (1995), Everett (1994), Cardinaletti \& Starke (1999), Auger (1994); assim como trabalhos mais recentes, Duarte \& Matos (2000), Galves (2001), Galves \& Abaurre (2002), Brito, Duarte \& Matos (2003), Harley \& Ritter (2002), Déchaine \& Wiltschko (2002), De Cat (2004), Raposo (1999, 2000), Carvalho (2008), entre muitos outros. No geral, esses trabalhos têm em comum o fato de estarem de acordo com a noção outrora captada por Câmara Jr. de item/forma dependente e discutirem o estatuto destas formas ou pro-formas ${ }^{41}$ a partir dos traços que os compõem. Everett (1996) e Auger (1994) por exemplo, seguindo uma abordagem 'mais morfológica', tratam essas formas como 'categorias afixais' ou 'marcadores de concordância' em adjunção ao núcleo funcional responsável pela concordância da frase. Uma série de trabalhos também analisou o uso dessas 'formas dependentes' nos dialetos do norte da Itália, no francês antigo e contemporâneo, bem como nas línguas românicas de modo geral. Na seção 2.4.3, retorno às análises propostas por alguns desses trabalhos.

Voltando às noções linguísticas, mencionadas anteriormente, de Câmara Jr., elas serão revistas pelos estudos em teoria sintática ao ampliarem sistemática e tipologicamente a tradicional classificação pronominal. Alguns estudos propuseram a tripartição pronominal (Cardinaletti \& Starke, 1999); afixos de concordância em lugar de pronomes clíticos (Everett, 1994; Auger, 1994); propostas de geometria de traços (Carvalho, 2008); a teoria de traços minimalista (Cf. Chomsky, 1999), para citar alguns deles.

\subsection{O estatuto pronominal e a Teoria de Regência e Ligação - TRL}

As noções gramaticais, tais como as de Câmara Jr, mencionadas na seção anterior, foram revistas pelos estudos linguísticos nas diferentes abordagens teóricas e, em particular,

como categorias lexicais principais do tipo $[+/-\mathrm{N}$ e $+/-\mathrm{V}]$ paralelamente à noção de categoria sintagmática. Assim, os pronomes pessoais não substituem as categorias lexicais $[+\mathrm{N}]$, mas a categoria sintagmática NP.

${ }^{41} \mathrm{O}$ conceito de pro-forma (elemento gramatical representante de um outro elemento) está ligado à possibilidade de retomada anafórica tanto de itens lexicais: pro-nomes (pronomes), pro-adjetivos, proadvérbios, pro-verbos quanto sentenciais: pro-sentenças (O João [foi ao cinema $]_{i}$ e a Maria [também] $]_{i}$ ). 
na teoria sintática, e ampliou-se sistemática e tipologicamente a tradicional classificação pronominal.

Nas versões iniciais dos modelos teóricos gerativos e também no modelo de Regência e Ligação (Chomsky, 1981) e de Princípios e Parâmetros (Chomsky, 1986), postulava-se o que era chamado até então 'sistema de regras' - o Rule Systems - cujos sintagmas nominais organizavam-se por meio de 'regras transformacionais' centradas na 'organização' das categorias sintagmáticas, responsáveis pela formação das frases ou, para ser mais exato, pela sequência linear dos itens lexicais, resultado da Estrutura Superficial. Assim, uma oração, representada por S, era formada por 'regras' que linearizavam os sintagmas NP(s) e VP (S $\rightarrow$ NP VP); o VP, por V e NP (V $\rightarrow$ V NP); o NP, por Det e N (NP $\rightarrow$ DET N) etc. Tais 'regras' não serão discutidas aqui, mas é importante dizer que, na organização das categorias sintagmáticas, estava um número reduzido ou finito de categorias lexicais compreendidas como principais e secundárias. As principais eram o nome $(\mathrm{N})$, o verbo (V), a preposição (P) e o Adjetivo (Adj), e as secundárias ou menores, atuando como modificadores das categorias lexicais principais, o Determinante (D), o Quantificador (Q), o Possessivo (Poss), entre outras. Por trás dessa assunção estava a intuição de que as categorias $\mathrm{N}, \mathrm{V}, \mathrm{P}$ e A eram o produto de uma combinação de traços binários distintos (+/-). ${ }^{42}$

Uma consideração a ser feita relativamente aos pronomes pessoais e demonstrativos é o fato de eles não substituírem a categoria lexical N, mas a categoria sintagmática NP. Assim, como menciona Raposo (1992, p. 68), no exemplo, renumerado, em (1a), a seguir, o pronome pessoal ele pode substituir o NP o aluno inteligente mas não o nome aluno, já que se torna agramatical o mesmo exemplo com o pronome substituindo o nome, na versão (1b):

(1) a. O aluno inteligente tirou uma boa nota

b. ${ }^{*} \mathrm{O}$ ele inteligente tirou uma boa nota

$\mathrm{Na}$ verdade, as formas conhecidas tradicionalmente como pronomes são elementos que veiculam noções gramaticais (como os traços- $\varphi$ ), e sintático-semânticas (como a coreferência - relação que se estabelece entre duas expressões nominais usadas com valor referencial) e são muito diferentes entre si.

Ainda outra observação necessária a ser feita, diz respeito ao desenvolvimento dentro da teoria sintática relativamente aos constituintes nominais NPs (DPs). Essas categorias tanto complexas (o aluno) quanto nuas (aluno) foram tratadas anteriormente por

\footnotetext{
${ }^{42}$ Alguns autores (como Raposo, 1992) incluem o Advérbio na Categoria Lexical Principal (AdvP).
} 
Chomsky $(1970,1986)$ como categorias lexicais do tipo NP em cuja projeção continha o determinante ocupando a posição de argumento externo de NP e o nome a posição de núcleo de $\mathrm{N}^{0}$ (cf. 2a, abaixo); nas projeções com nomes nus, a posição Spec NP ficava vazia (cf. 2b):

(2) a.

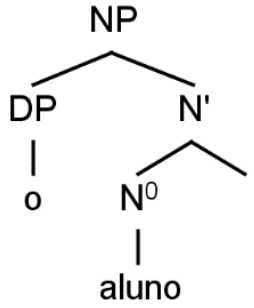

b.

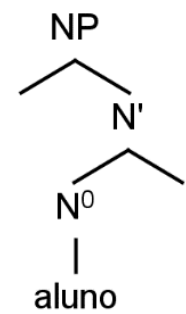

Posteriormente, surgiu uma nova configuração representacional para os sintagmas nominais, fossem eles complexos ou nus, e ficou conhecida como "hipótese DP". Abney (1986), foi um dos primeiros a propor essa hipótese, baseando-se nas semelhanças existentes entre os NPs e as sentenças. Essa hipótese seguia a ideia de que, assim como nos constituintes oracionais uma categoria funcional como TP (responsável pelos traços de Agr e Tempo) seleciona um complemento lexical VP. D (responsável por traços funcionais como referencialidade, definitude, número, concordância etc.) também selecionaria uma categoria lexical (NP) como complemento. Assim, a projeção máxima do sintagma o aluno em (2a), por exemplo, não seria mais um NP e sim um sintagma determinante DP que teria como núcleo uma categoria funcional $\mathrm{D}^{0}$. Chomsky (1999 [1995], p. 456), seguindo Longobardi (1994), assume que a natureza 'quase-referencial' (e indéxica) de um grupo nominal é uma propriedade do núcleo D do DP, sendo o NP uma espécie de predicado. Os pronomes pessoais, portanto, não substituem a categoria sintagmática NP, mas DP. Assim, no exemplo apresentado em (1b) acima, o pronome ele substitui todo o DP o aluno inteligente, seguindo a "hipótese DP". 43

Essas noções gramaticais das categorias nominais e pronominais vêm sendo estudadas pela linguística há longo tempo, em diferentes quadros teóricos, e já foram bastante refinadas. No quadro teórico de Regência e Ligação, por exemplo, em Chomsky (1981), as categorias PRO, expressão-R e vestígio-NP ao mesmo tempo que têm semelhanças, possuem traços que as distinguem das categorias exclusivamente pronominais (cujas características gramaticais são 'traçadas' a partir dos traços $\varphi$ ). Ao passo que a anáfora

\footnotetext{
${ }^{43}$ Recentemente, seguindo a proposta de "concha $v \mathrm{P}$ " de Chomsky (1995), baseada em Larson (1994), autores como Aboh (2007), entre outros, propuseram o $n \mathrm{P}$. Segundo Aboh, na estrutura dos segmentos nominais ocorre um $n \mathrm{P}$ que, a princípio, também serviria para expressar relações de causa e agentividade, como ocorre na estrutura $v \mathrm{P}$.
} 
e as expressões-R têm outras características gramaticais que extrapolam as noções de pessoa, gênero e número relativamente aos traços $\varphi$ :

There is some set of gramatical features $\varphi$ that characterize pronouns: i.e., pronouns are distinguished from overt anaphors and R-expressions in that the gramatical features of pronouns are drawn solely from $\varphi$, whereas overt anaphors and R-expressions have some other gramatical features as well. Thus John and each other each have some gramatical feature that identifies them as non-pronominal, i.e. some feature outside of the set $\varphi$.

$(\text { CHOMSKY, 1981, p. 330) })^{44}$

A título de ilustração, retomo as noções gramaticais abordadas por Câmara Jr. (1996), feitas na seção anterior, quanto à caracterização dos pronomes com relação ao que os diferenciam dos nomes: (i) a noção de pessoa gramatical, (ii) a noção gramatical, existente em vários pronomes, de um gênero neutro em função substantiva, quando a referência é a coisas inanimadas: isto, isso, aquilo e formas específicas para seres humanos: alguém, ninguém e outrem, e (iii) a categoria de casos. Mas as formas pronominais, se de um lado são também elementos lexicais (o pronome lexical), ou elementos que substituem os nomes; por outro lado, elas são vistas sob condições bastante distintas ${ }^{45}$ das das categorias lexicais principais $^{46}$. Para tal, os estudos linguísticos passaram a diferenciar as tradicionais formas pronominais face a certas noções pragmáticas, semânticas e sintáticas, como a referencialidade, a especificidade, as noções de pessoa (pessoa vs não-pessoa - nos termos de Benveniste (1976, p. 279) etc. A interpretação de itens pronominais com a mesma forma, ligados à noção de co-referência, passaram a ser vistos como fenômenos sintáticos com distinções peculiares e com necessidade de terem status independentes, como a anáfora, o pronome ('independente' referencialmente), a expressão- $R$, e ainda as categorias vazias como PRO e pro. A título de exemplo, observe as sentenças abaixo: ${ }^{47}$

(3) a. O pai d[o João]i obrigou o [miúdo $]_{i}$ a sair de casa ${ }^{48}$

b. [O Luís]i pensa que [ele $]_{i / j}$ é o mais inteligente da turma

c. [O Luís $]_{i}$ fotografou-[se] $]_{i}$ (a si próprio)

\footnotetext{
44 Tradução aproximada: "Há um conjunto de traços gramaticais $\varphi$ que caracterizam os pronomes, isto é, os pronomes se distinguem das anáforas e expressões-R uma vez que as suas características gramaticais são 'traçadas' exclusivamente a partir de $\varphi$, ao passo que a anáfora e as expressões-R têm algumas outras características gramaticais também. Assim, João e um ao outro têm, cada um deles, certas características gramaticais que os identificam como não-pronominais, ou seja, alguma característica fora da extensão de $\varphi$ ”.

${ }^{45}$ Grosso modo, pode-se dizer que as categorias pronominais, especialmente as clíticas, constituem uma classe fechada que se aproximam das classes funcionais.

${ }^{46}$ É comum a referência às formas lexicais dos pronomes, mas nesse caso essas formas não têm o estatuto das categorias lexicais principais do tipo (+/- $\mathrm{N}$ e $+/-\mathrm{V})$.

${ }^{47}$ Exemplos retirados de Raposo (1992, p. 239-240 e renumerados).

${ }^{48}$ Ao lado da leitura correferencial, é possível uma leitura disjunta dos NPs [o João] e [o miúdo]j.
} 
em que DPs e itens pronominais têm comportamentos peculiares, podendo ter antecedentes dentro das orações, mas também fora delas. Em (3a): o DP 'o miúdo' tem o DP 'o João' como seu antecedente; em (3b) o pronome 'ele' pode ter tanto o DP 'o Luís' como seu antecedente quanto pode se referir a um outro DP fora do enunciado; em (3c) o pronome 'se' tem obrigatoriamente o DP 'o Luís' como seu antecedente único. Assim, há elementos com autonomia referencial e outros que não possuem nenhuma autonomia. A teoria convencionou chamar aqueles elementos que precisam de antecedentes, ou que não têm independência referencial, de anáfora, marcando uma oposição entre a anáfora e o pronome (que não precisa ter antecedente, necessariamente); ou seja, todo item pronominal precisa ter um referente, no entanto, as condições pragmáticas dos enunciados garantem ao pronome 'certa autonomia' referencial, o que não ocorre com a anáfora. As matrizes fonéticas dos pronomes e das anáforas possuem traços $\varphi$ especificados em gênero, número, pessoa e caso (Chomsky, 1981, p. 330), mas a diferença entre eles está tanto nas questões semântico-pragmáticas quanto na distribuição sintática desses nas orações, ou, em outras palavras, por suas propriedades de Ligação - definidas teoricamente pela propriedade de c-comando. Na seção seguinte, retomo a diferença entre anáfora e pronome, lançando mão da noção de $c$-comando.

\subsubsection{O conceito de Ligação, o estatuto pronominal e a noção de $C$-comando ${ }^{49}$}

A distribuição das categorias DPs nas orações são guiadas por vários tipos de restrições, definidas pela noção de ligação. O conceito de ligação, também traduzido como vinculação, foi desenvolvido dentro da concepção modular da linguagem proposta na Teoria de Regência e Ligação (Chomsky, 1981) e retomado em Princípios e Parâmetros (Chomsky, 1986). Nessa concepção, ligação é o módulo gramatical responsável pela atribuição de interpretação apropriada quanto à distribuição dos índices referenciais, fornecendo uma formulação das restrições dos DPs. Segundo Raposo (1992, p. 239) o estudo das

\footnotetext{
${ }^{49}$ No quadro minimalista, o papel desempenhado pelas estruturas de constituintes perde a relevância dos 'modelos' anteriores - as estruturas passaram a ser 'despojadas' (cf. Chomsky, 1995 (tradução de Raposo, 1999b)) e, nesse sentido, tem havido um esforço em se dispensar as definições de tipo configuracional como o c-comando. As restrições impostas por $c$-comando seriam derivadas da hierarquia de relações temáticas com as quais se estabelecem as relações de constituência, dissociando as restrições de precedência linear das restrições de dominância.
} 
dependências referenciais entre DPs com potencial de referência é uma das áreas empíricas que tem recebido maior atenção por parte dos gerativistas, sobretudo, a partir dos anos $60 .{ }^{50}$

O principal legado da Teoria de Ligação foi o desenvolvimento do estudo dos diversos tipos de DPs, de uma tipologia desses elementos e as diferentes propriedades distribucionais de cada um deles: DPs com matriz fonológica, como Expressões Referenciais, Nomes, Pronomes, Anáforas etc. e os DPs sem matriz fonológica, como PRO, pro e ec.

A Teoria de Ligação introduziu também uma outra definição imprescindível à noção dos DPs que são os Princípios $A, B$ e $C$, ligados diretamente à noção configuracional de $c$ comando. Essas noções constituem o estado da arte da categoria pronominal em termos teóricos, são refinações que revolucionaram, por assim dizer, o estudo desse item gramatical e são vanguarda até os dias atuais. Como já mencionado, a definição das categorias pronominais abarcaram noções bastante restritivas: pronomes pessoais, anáfora e expressões referenciais, são definidas tipologicamente sob princípios estabelecidos a partir da relação configuracional de c-comando.

A noção de c-comando (Reinhart, 1976; Chomsky, 1981, 1986, 1999b) ${ }^{51}$ é dada a partir da definição de domínio em que um sintagma ocorre. Assim, o domínio de um determinado núcleo $(\alpha)$ é a projeção máxima que o contém. O domínio de V é VP, portanto $\alpha$ c-comanda todo elemento desse domínio que não está contido em $\alpha$. A título de exemplo, transcrevo, de Chomsky (1999b, p. 75), as configurações referentes às duas relações básicas sintagmáticas: a dominância e a linearidade, indicadas na relação configuracional em (4), em cujas relações básicas se diz que $\mathbf{B}$ domina $\mathbf{D}$ e $\mathbf{E}, \mathbf{C}$ domina $\mathbf{F}$ e $\mathbf{G}$, e $\mathbf{A}$ domina todos os outros nós. E ainda, B precede $\mathbf{C}, \mathbf{F}$ e $\mathbf{G}$, e assim por diante. A relação de precedência também será primordial para estabelecer os princípios que diferenciam, por exemplo, as categorias pronominais anáfora e pronome. ${ }^{52}$

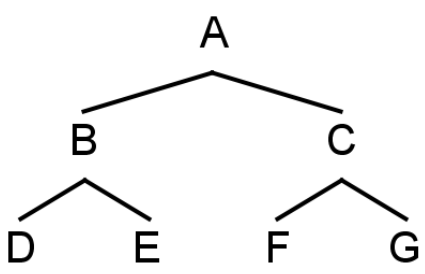

\footnotetext{
${ }^{50}$ Em nota de rodapé, Raposo (1992, p. 239) esclarece que os primeiros estudos sobre a co-referência no âmbito da Gramática Gerativa remontam a Lees e Klima (1963), Postal (1966, 1971), Ross (1967) e Langacker (1969).

${ }^{51}$ Segundo Brito, Duarte \& Matos (2003, p. 799), a noção de c-comando foi inicialmente proposta por Reinhart (1976) e na Teoria de Regência e Ligação é, em geral, aceita a definição proposta inicialmente.

${ }^{52}$ Retirado de Chomsky (1999b - Trad. Eduardo Paiva Raposo).
} 
Assim, na definição de $c$-comando, são fundamentais as relações sintagmáticas de dominância, linearidade e precedência vistas acima:

C-comando:

$\alpha$ c-comanda $\beta$ se e somente se:

(i) $\quad \alpha$ não domina $\beta$ nem $\beta$ domina $\alpha$;

(ii) cada nódulo ramificante $\gamma$ que domina $\alpha$ também domina $\beta$.

Dizendo de outro modo (Chomsky, 1999b, p. 76): “ $\alpha$ c-comanda $\beta$ se não domina $\beta$ $e$ todo $\gamma$ que domina $\alpha$ domina $\beta$ ". Nesse sentido, retomando a configuração vista em (4), acima, temos que:

(i) $\quad \mathbf{B}$ c-comanda $\mathbf{C}, \mathbf{F}$ e $\mathbf{G}$;

(ii) $\mathbf{C}$ c-comanda $\mathbf{B}, \mathbf{D}$ e E;

(iii) $\mathbf{D}$ c-comanda $\mathbf{E}$

(iv) $\quad \mathbf{E}$ c-comanda $\mathbf{D}$

(v) $\quad \mathbf{F}$ c-comanda $\mathbf{G}$

(vi) $\mathbf{G}$ c-comanda $\mathbf{F}$

Mas, em (4), A não c-comanda $\mathbf{B}$ nem $\mathbf{C}$, e também $\mathbf{B}$ não $c$-comanda $\mathbf{D}$ nem $\mathbf{E}$; nem $\mathbf{C}$ c-comanda $\mathbf{F}$ e G, uma vez que há, entre esses nós, relação de dominância, o que exclui, por definição, a noção de $c$-comando.

Outro item a ser mencionado são os princípios $\mathbf{A}, \mathbf{B}$ e $\mathbf{C}$ da Teoria de Ligação (Cf. Chomsky, 1986, p. 166):

A: uma anáfora tem de estar ligada no domínio local ou domínio mínimo;

B: um pronome é livre no domínio local ou domínio mínimo;

$C$ : uma expressão-R deve estar livre.

Voltando aos exemplos (3) na seção anterior, repetidos abaixo em (5), e alterados em (6), já é possível fazer novas considerações sobre eles, levando em conta as noções de $c$ comando: 
(5) a. O pai d[o João]i obrigou o miúdoi a sair de casa

b. [O Luí]s $]_{i}$ pensa que ele $\mathrm{i}_{\mathrm{j} j}$ é o mais inteligente da turma

c. [O Luís] $]_{i}$ fotografou-se ${ }_{i}$ (a si próprio)

(6) a. *[O pai do João]i obrigou o miúdo a sair de casa

b. *[O Luís $]_{i}$ pensa que $\mathrm{si}_{\mathrm{i}}$ é o mais inteligente da turma

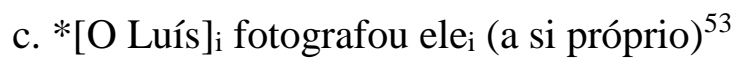

Todos os exemplos de (6) são agramaticais por uma única razão: restrições impostas às relações de dominância captadas pela noção de c-comando. Em (6a) há uma relação de simetria entre os DPs [O pai do João] e [o miúdo] e, consequentemente, ocorre $c$-comando mútuo entre eles, no entanto, não é unicamente essa simetria a responsável pela agramaticalidade da oração, mas um outro problema - a restrição à co-referencialidade entre os DPs -, captada pelo princípio C: uma expressão-R deve estar livre.

Por outro lado, a gramaticalidade de (5a) se deve pelo fato de não haver coindexação do DP completo [O pai do João], mas apenas de parte dele - seu complemento [o João] - um DP contido dentro de um PP subcategorizado por um núcleo NP, domínio onde não pode ocorrer $c$-comando e nem se aplica o referido princípio $C$.

Em (6b) o DP [O Luís] c-comanda o reflexivo [si], mas está separado dele por um nó oracional (CP), o que torna a oração agramatical, já que as propriedades referenciais dos reflexivos exigem que eles sejam c-comandados em domínio oracional local, como menciona o Princípio A: uma anáfora tem de estar ligada no domínio local ou domínio mínimo.

Finalmente, (6c) é agramatical porque está sendo co-indexado em um domínio oracional incompatível com suas propriedades referenciais, uma vez que as propriedades referenciais do pronome [ele] em (6c) restringem que ele seja c-comandado num domínio local, já que pronomes são sensíveis ao Princípio B: um pronome é livre no domínio local ou domínio mínimo.

Mencionada a noção de c-comando e os princípios $A, B$ e $C$ da Teoria de Ligação, norteadores das expressões referencias; na seção seguinte, passo a uma definiçãa mais detalhada da tipologia dessas expressões: anáfora, pronome e expressão- $R$.

\footnotetext{
${ }^{53}$ É possível, no entanto, dizer: O Luís fotografou ele mesmo ${ }_{i}$ (ao menos, em PB).
} 


\subsubsection{As anáforas}

A noção de anáfora em certos quadros teóricos abrange fenômenos distintos tanto pela forma gramatical (nominal, pronominal, elipse, etc.) quanto pela natureza referencial da forma anafórica. Os estudos sintáticos com base na teoria de Ligação e face à noção de $c$ comando restringiram o termo anáfora aos elementos localmente ligados ao seu antecedente e referencialmente dependentes - anáfora ligada ${ }^{54}$. São exemplos de anáforas, portanto, os pronomes reflexivos e recíprocos. Além da restrição imposta aos elementos anafóricos por serem dependentes referencialmente, e por não poderem ocorrer sem seu antecedente, uma segunda restrição, segundo Mioto et alii (2005, p. 218), diz respeito à noção de precedência, face à relação de hierarquia entre os constituintes. Como se pode conferir nos exemplos a seguir, em que (7a-b) exigem que o DP a Maria preceda a anáfora e (7c-d) com clara restrição quanto ao elemento do DP expandido que funciona como antecedente da anáfora: ${ }^{55}$

(7) a. [A Maria]i se adora

b. *[A Maria $]_{\mathrm{i}} \mathrm{se}_{\mathrm{k}}$ adora

c. [A mãe do Pedro]i se $_{i}$ adora

d. *A mãe d[o Pedro]i se sedora

As anáforas, portanto, distinguem-se dos pronomes por suas propriedades referenciais fortemente dependentes que precisam estar ancoradas dentro do enunciado e ligadas localmente ao seu referente, em consonância ao Princípio A da Teoria de Ligação: uma anáfora tem de estar ligada no domínio local ou domínio mínimo. ${ }^{56}$

$\mathrm{Na}$ distinção entre anáforas e pronomes, no entanto, há vários outros aspectos a se considerar; um deles é, inclusive, bastante intrigante - diz respeito ao fato de os pronomes de primeira e segunda pessoas terem, nas línguas românicas, a mesma forma tanto para a anáfora quanto para o pronome clítico, nos casos de co-referência e referência disjunta, como se pode verificar nos exemplos em (8), a seguir, de línguas como português e francês. Nesses exemplos, as orações da coluna (a), têm referência disjunta e os elementos são pronominais e

\footnotetext{
${ }^{54}$ Brito, Duarte \& Matos (2003, p. 801) explicam que, na retórica, a anáfora é considerada uma figura de estilo que consiste na repetição de uma palavra no início de enunciados. Na Linguística moderna, o conceito de anáfora não é uniforme, tendendo a ser visto como o processo que consiste em utilizar uma forma linguística ou um vazio para remeter a um antecedente (algo dito anteriormente), cf.: $O$ teu irmão chegou de férias; ele/[Ø] chegou ontem; ou, numa perspectiva estritamente sintática, refere-se aos elementos pronominais possessivos e recíprocos - $\mathrm{a}$ anáfora ligada.

${ }^{55}$ Exemplos retirados de Mioto (2005, p. 218, renumerados).

${ }^{56}$. Segundo Brito, Duarte \& Matos (2003, p. 806), no PE, o possessivo anafórico por excelência parece ser nulo [Ø], conforme os exemplos: A Maria cortou o cabelo; a mãe viu a filha.
} 
as da coluna (b) trata-se de anáforas (ligadas). Já em inglês, os mesmos exemplos, por terem formas distintas, os pronominais e as anáforas de $1^{\mathrm{a}}$. e $2^{\mathrm{a}}$. não se confundem. As anáforas marcadas por - self / selves permitem que, na língua inglesa, não haja ambiguidades entre elas e as formas pronominais, relação menos transparente nas línguas românicas: ${ }^{57}$

\section{Pronomes}

(8) a. Mariai $m e \mathbf{j}$ viu

Mariai $t e_{\mathbf{j}}$ viu

Mariai $n o s$ j viu

Mariei $m_{\mathbf{j}}$ ' a vu

Mariei $t_{j}$ 'a vu

Marie $_{\text {i }}$ ous j a vu

Mary saw me

Mary saw you

Mary saw us
Anáforas

b. Eui $m e \mathbf{i}$ vi

$\mathrm{Tu}_{\mathbf{i}} t e_{\mathbf{i}}$ viste

Nósi nosi vimos

$\mathrm{Je}_{\mathbf{i}} m e_{\mathbf{i}}$ suis vu

Tui $t_{i}$ 'es vu

Nousi nousi sommes vu

I saw myself

You saw yourself

We saw ourselves

Na Gramática da Língua Portuguesa (organizada por Mateus et alii, 2003) Brito, Duarte \& Matos, (p. 815) resumem em forma de Quadro - Quadro 3 - as formas pronominais pessoais que se comportam como anáforas em língua portuguesa.

57 Os exemplos das línguas inglesa e francesa foram retirados de Déchaine \& Wiltschko (2002, p 430, renumerados). 
Quadro 3 - Anáforas ligadas ${ }^{58}$

\begin{tabular}{|c|c|c|c|c|c|}
\hline & \multicolumn{3}{|c|}{ Reflexos } & \multicolumn{2}{|c|}{ Recíprocos } \\
\hline $\begin{array}{c}\text { Pessoas } \\
\text { gramaticais }\end{array}$ & $\begin{array}{c}\text { Anáforas } \\
\text { locais }\end{array}$ & $\begin{array}{l}\text { Anáfora } \\
\text { local/ } \\
\text { de longa } \\
\text { distância }\end{array}$ & $\begin{array}{l}\text { Reforço } \\
\text { de anáforas } \\
\text { reflexas }\end{array}$ & & $\begin{array}{l}\text { Reforço } \\
\text { de anáforas } \\
\text { recíprocas }\end{array}$ \\
\hline 1. ${ }^{a}$ singular & me & & $\begin{array}{l}\text { a mim próprio/ } \\
\text { mesmo }\end{array}$ & & \\
\hline 2. a singular & te & & $\begin{array}{l}\text { a ti próprio/ } \\
\text { mesmo }\end{array}$ & & \\
\hline 3. ${ }^{a}$ singular & se & si & $\begin{array}{l}\text { a si próprio/ } \\
\text { mesmo }\end{array}$ & & \\
\hline 1. ${ }^{\mathrm{a}}$ plural & nos & & $\begin{array}{c}\text { a nós próprios/ } \\
\text { mesmos }\end{array}$ & (nos) & $\begin{array}{c}\text { uns (prep.) } \\
\text { outros }\end{array}$ \\
\hline 2. ${ }^{a}$ plural & vos & & $\begin{array}{c}\text { a vós próprios/ } \\
\text { mesmos }\end{array}$ & (vos) & $\begin{array}{l}\text { uns (prep.) } \\
\text { outros }\end{array}$ \\
\hline 3. ${ }^{\mathrm{a}}$ plural & se & si & $\begin{array}{l}\text { a si próprios/ } \\
\text { mesmos }\end{array}$ & se & $\begin{array}{c}\text { uns (prep.) } \\
\text { outros }\end{array}$ \\
\hline
\end{tabular}

No entanto, as anáforas ligadas, acima, em variedades populares do PB (PVB), diferentemente do PE, podem apresentar paradigmas cuja forma de $3^{\mathrm{a}}$. pessoa se ocorre como default, sem oposição quanto ao traço de pessoa:

(9) a. Eu/nós se vi/viu

b. Tu/você se viu

$c$. Ele/ela se viu

Para finalizar, é importante registrar o valor correferencial da forma tônica si. Normalmente acompanhada de preposição, si assemelha-se à forma clítica se por funcionar como anáfora ligada, ao mesmo tempo que distingue-se de se por funcionar também como anáfora de longa distância, ou seja, não ligada localmente:

(10) A Maria $\mathrm{i}_{\mathrm{i}}$ soube directamente do João $\mathrm{j}$ que que alguém tinha falado mal de $\mathrm{si}_{\mathrm{i}} /{ }_{\mathrm{j}}{ }^{59}$

\footnotetext{
${ }^{58}$ Quadro retirado de Brito, Duarte \& Matos (2003 p. 815, renumerado).

${ }^{59}$ Exemplo retirado de Brito, Duarte \& Matos (2003 p. 814, renumerado).
} 


\subsubsection{Os pronomes}

Segundo Mioto et alii (2005) são considerados pronomes, do ponto de vista teórico, apenas aqueles que as gramáticas normativas chamam de pronomes pessoais, exceto os reflexivos e os recíprocos (que são anáforas). Como já mencionado na seção anterior, os pronomes têm propriedades distintas das anáforas, o que faz das anáforas e pronomes elementos com propriedades distribucionais complementares. Nos exemplos em (11), os índices mostram as restrições na distribuição dos mesmos: ${ }^{60}$

(11) a. A Mariai adora ela

b. *A Mariai adora ela

c. A Joana $\mathrm{i}_{\mathrm{i}}$ disse que a Maria $\mathrm{j}_{\mathrm{j}}$ adora ela $\mathrm{i}_{\mathrm{i} / \mathrm{k}}$

em (11a) o pronome 'ela' pode se referir a qualquer DP do gênero feminino mas não ao antecedente, estando de acordo com o Princípio $B$ da Teoria de Ligação: um pronome é livre no domínio local ou domínio mínimo. O mesmo princípio $B$ e também o princípio $A$ : uma anáfora tem de estar ligada no domínio local ou domínio mínimo - restringem que (11b) seja gramatical, já que apenas as anáforas podem ocorrer em domínios mínimos. Já em (11c), o pronome 'ela' tanto pode ser co-referente ao primeiro DP, quanto pode ter referência disjunta já que num domínio não mínimo ele é livre.

Porém, a definição de pronome baseada na tipologia 'pronomes pessoais' que defendo nesse trabalho, não é unânime na literatura. Na Gramática da Língua Portuguesa (organizada por Mateus et alii) Brito, Duarte \& Matos (2003) restringem tipologicamente sob o rótulo de pronome apenas os pronomes pessoais de terceira pessoa face ao traço de coreferencialidade típica da terceira pessoa. A primeira e segunda pessoas são definidas tipologicamente pelas autoras como Expressões Referenciais:

(...) a partir deste momento designaremos anáforas apenas os reflexivos e os recíprocos e pronomes os pronomes pessoais de $3^{\mathrm{a}}$. pessoa. Deste modo, os pronomes $e u, t u$, nós, vós só têm valor dêitico, nunca podendo ter valor de co-referência

(Brito, Duarte \& Matos, 2003 p. 806).

Na próxima seção, em que apresento as Expressões-R, retomo essa discussão.

\footnotetext{
${ }^{60}$ Exemplos retirados de Mioto et alii (2005, p. 224, renumerados).
} 
No Quadro 4, abaixo, as autoras (op. cit.) consideram as formas pronominais, separadas tipologicamente pelo seu valor referencial: formas co-referencias e não coreferenciais (dêiticas), opondo-se a $1^{\mathrm{a}}$. e a $2^{\mathrm{a}}$. pessoa à $3^{\mathrm{a}}$ :

Quadro 4 - Pronomes Pessoais (formas fortes) ${ }^{61}$

\begin{tabular}{|c|c|c|c|}
\hline \multirow[b]{3}{*}{$\begin{array}{l}\text { Pessoas } \\
\text { gramaticais }\end{array}$} & \multicolumn{3}{|c|}{ Casos } \\
\hline & \multicolumn{2}{|c|}{ Nominativo } & \multirow[t]{2}{*}{ Oblíquo } \\
\hline & $\begin{array}{l}\text { Apenas } \\
\text { valor } \\
\text { dêictico }\end{array}$ & $\begin{array}{l}\text { Valor dêicticol } \\
\text { co-referencial }\end{array}$ & \\
\hline 1. a singular & $\mathrm{eu}$ & & (prep.) mim, (co)migo \\
\hline \multirow{2}{*}{ 2. ${ }^{a}$ singular } & tu & & (prep.) ti, (con)tigo \\
\hline & você & & (prep.) si \\
\hline $3{ }^{a}$ singular & & ele, ela & (prep.) ele, ela, si \\
\hline 1. ${ }^{\mathrm{a}}$ plural & nós & & (prep.) nós, con(nosco) \\
\hline \multirow{2}{*}{ 2. ${ }^{a}$ plural } & vós & & (prep.) vós, (con)vosco \\
\hline & vocês & & \\
\hline 3. ${ }^{\mathrm{a}}$ plural & & eles, elas & (prep.) eles, elas, si \\
\hline
\end{tabular}

Além das formas fortes dos pronomes pessoais, há também as formas clíticas ou formas deficientes (cf. Cardinaletti e Starke, 1999); apresento essas formas na seção (2.4).

Uma curiosidade entre o português e as demais línguas românicas é o fato de, em português, não haver pronomes sujeitos clíticos, a não ser os casos em que o clítico 'se' funciona como sujeito sintático. ${ }^{62}$

No Quadro 4, o uso da forma 'si' tônica de segunda pessoa no português europeu contrasta fortemente com o português brasileiro; o valor dêitico (e também referencial) de 'si' correspondente a 'você' é inexistente no PB. 'Si' em PB será sempre interpretado como [+anáfora]; [-pronome]: ${ }^{63}$

(12) isto é para $s i^{64}$

\footnotetext{
${ }^{61}$ Quadro retirado de Brito, Duarte \& Matos (2003 p. 819, renumerado).

${ }^{62} \mathrm{O}$ pronome clítico de $3^{\mathrm{a}}$. pessoa $s e$ tem função nominativa em construções como: Come-se bem em São Paulo!

$63 \mathrm{O}$ pronome $\mathrm{Si}$, conforme mencionado na seção anterior, no $\mathrm{PB}$, nunca tem valor referencial, mas correferencial, podendo funcionar apenas como anáfora.

${ }^{64}$ Exemplo retirado de Brito, Duarte \& Matos (2003, p. 813, renumerado).
} 
Em PE a sentença (12) é uma construção de uso corrente na língua e é 'interpretada' como: 'isto é para você/o(a) senhor(a), com o traço [+formal]. Uma construção com sentido análogo em PB só é possível com o pronome oblíquo de $2^{\mathrm{a}}$. pessoa 'ti', ou com o pronome forte 'tu', em alguns dialetos, ou, simplesmente com o pronome 'você', conforme (13a, b e c):

(13) a. isto é para $t i$

b. isto é para $t u$

c. isto é para você $(o(a)$ senhor $(a))$

\subsubsection{As expressões- $R$}

O princípio $C$ da Teoria da Ligação (cf. Chomsky, 1986) define as expressões-R como itens livres: "uma expressão-R deve estar livre". Elas são tratadas pela teoria sintática como itens lexicais com autonomia referencial. São DPs do tipo [o João], [a Maria], [o Palácio do Planalto]. Nesse sentido, distinguem-se das anáforas e dos pronomes diretamente pelos princípios $A$ e $B$ da Teoria da Ligação (Chomsky, 1986, p. 166):

\section{A: uma anáfora tem de estar ligada no domínio local ou domínio mínimo;}

B: um pronome é livre no domínio local ou domínio mínimo;

Assim, as expressões-R opõem-se às anáforas - itens dependentes localmente de um antecedente para fixar sua referência, (i) por não serem capazes de 'referirem' por si só (cf. princípio $A$ ); e (ii) pelo princípio $B$ da Teoria de Ligação, também distinguem-se dos pronomes - elementos que têm certa independência referencial, podendo ter sua referência ancorada em um antecedente na oração desde que em um domínio não mínimo (cf. princípio $B$ ), ou no discurso, a depender das condições pragmáticas dos enunciados.

A título de exemplo, vejamos as orações em (14) abaixo: ${ }^{65}$

(14) a. O João não beijou a Maria na festa.

b. Os meninos gostam de sorvete.

c. O livro está na mesa amarela.

\footnotetext{
${ }^{65}$ Exemplos retirados de Mioto et alii (2005, p. 226, renumerados).
} 
Em que todos os DPs em (14) dispensam a presença de um antecedente.

Segundo Mioto et alii (2005), as expressões-R também são impossíveis em vários contextos sintáticos em que os pronomes podem ocorrer, conforme os exemplos em (15): ${ }^{66}$

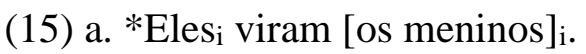

b. ${ }^{*} \mathrm{O}$ Pedrok ouviu eles $\mathrm{i}$ elogiarem [os meninos $]_{\mathrm{i}}$

c. *Elesi disseram que [os meninos]i saíram

As razões que impossibilitam a expressão-R [os meninos] nas ocorrências em (15a, b, c) acima, como explica Mioto et alii (2005, p. 227), são as restrições impostas por ccomando, ou seja, as expressões têm de ser livres, mas, ao contrário, estão sendo vinculadas tanto no domínio das anáforas (mínimo) em (15 a-b), quanto no domínio dos pronomes (não mínimo) em (15c).

Outra consideração que cabe aqui, diz respeito aos pronomes de $1^{\mathrm{a}}$. e $2^{\mathrm{a}}$. pessoas, pois, segundo Brito, Duarte \& Matos (2003, p 806), os pronomes pessoais de primeira e segunda pessoas $e u$, tu, nós, vós (vocês) só têm valor dêitico e funcionam como Expressões$\mathrm{R}$, não podendo ter valor de co-referência. Segundo as autoras, as Expressões-R, por terem autonomia referencial, não precisam de antecedente:

Do ponto de vista sintático, as expressões referenciais são Sintagmas Determinantes (SD), em posição argumental, constituídas por nome próprio, nome comum (com certo tipo de determinação/quantificação) ou pronomes de $1^{\mathrm{a}}$. e $2^{\mathrm{a}}$. pessoas $(e u, t u$, nós, vós) que só têm valor dêitico.

(Brito, Duarte \& Matos, 2003, p. 798)

Sobre tal acepção, é necessário tecer algumas considerações. As autoras definem os pronomes dentro de uma abordagem bastante restritiva e por trás dessa intuição está o fato de que os pronomes de $1^{\mathrm{a}}$. e $2^{\mathrm{a}}$. pessoas, por terem propriedades dêiticas e funcionarem como expressões- $R$, não podem funcionar como variáveis ligadas ou entidades referenciais, ou seja, aquelas que estabelecem a co-referência; estando sujeitos à Condição- $C$ já que expressões- $R$ devem estar livres - everywhere - em se tratando de frases complexas.

Por outro lado, buscando 'olhar' para além da 'acepção pronominal restritiva' das autoras, baseada no contexto situacional, há, no entanto, que se considerar que, além do contexto situacional, há também o discursivo. Em certos contextos (discursivos), principalmente em discursos indiretos, é sempre possível estabelecer co-referência com

${ }^{66}$ Exemplos retirados Mioto et alii (2005. p. 23, renumerados). 
pronomes de primeira e segunda pessoas - em que podem estar ligados fora do local de domínio, conforme a Condição-B. Os exemplos (16) e (17), a seguir, confirmam a possibilidade de co-referência em certos contextos discursivos, como nas narrativas, principalmente, no discurso indireto:

(16) [O João e o Pedro]i disseram: - [Nós]i devíamos telefonar para a Maria.

(17) a. uma das que começou foi a Umbelina? ${ }^{67}$

b. [a Umbelina a minha prima Fátima e eu]i... [nós três]i... aí elas sairu tudo... num ajudum direito... mas eu pego os jovem e eu continuo...

Neste trabalho, no entanto, não seguirei a mesma classificação de Brito, Duarte \& Matos (2003) quanto a $1^{\mathrm{a}}$. e $2^{\mathrm{a}}$. pessoas como expressões- $R$. Considero expressões- $R$ as categorias DPs de modo geral; as formas tanto de $1^{\mathrm{a}}$. e $2^{\mathrm{a}}$. pessoas, quanto as de $3^{\mathrm{a}}$., considero-as pronomes pessoais.

Em consonância com a tipologia das categorias lexicais, apresento um resumo, em forma de quadro, retirado de Mioto et alii (2005):

\section{Quadro 5 - Tipologia das categorias lexicais ${ }^{68}$}

\begin{tabular}{|c|c|c|}
\hline \multicolumn{3}{|c|}{ Tipologia dos DPs Lexicais } \\
\hline a. & {$[$ +anafórico, -pronominal $]$} & Recíprocos e reflexivos \\
\hline b. & {$[$-anafórico, +pronominal $]$} & Pronomes (pessoais) \\
\hline c. & {$[$-anafórico, -pronominal $]$} & Nomes (próprios ou comuns) \\
\hline d. & {$[$ +anafórico, +pronominal $]$} & $*$ \\
\hline
\end{tabular}

\subsection{O pronome clítico}

Nas seções anteriores apresentei a tipologia dos DPs lexicais (anáforas, pronomes e expressões referenciais), no entanto, ficaram de fora as formas pronominais clíticas (inclusas

\footnotetext{
${ }^{67}$ Exemplo retirado dos corpora da tese - em conversa com moradores de Jurussaca.

${ }^{68}$ Quadro retirado de Mioto et alii (2005 p. 232, renumerado).
} 
na classe dos pronomes pessoais). Muitas são as assimetrias entre as formas clíticas e as formas fortes. A discussão teórica dessa temática é extremamente extensa na literatura sobre a sintaxe pronominal; nesta seção discutirei alguns trabalhos relevantes dentro da área da sintaxe pronominal clítica.

Os pronomes clíticos são exemplos genuínos das formas dependentes mencionadas no início deste capítulo (Câmara Jr., 1972, p. 69-70) ou deficientes (nos termos de Cardinaletti e Starke, 1999). Uma das assimetrias entre as formas pronominais clíticas e fortes foi observada por Brito, Duarte \& Matos (2003) (B,D\&M, daqui em diante) relativamente às características referenciais dos clíticos de $3^{\mathrm{a}}$. pessoa em tomarem predicados como referentes. Assim, os pronomes fortes (Quadro 5, seção (2.3.2)) são descritos, tradicionalmente, como aqueles que se referem à pessoa gramatical das entidades participantes do ato da comunicação $(\mathrm{eu}=$ pessoa; $\mathrm{tu}=$ não eu; ele = não pessoa), enquanto os clíticos não reflexivos (Quadro 6, abaixo) são prototipicamente correspondentes átonos das formas dos pronomes tônicos e ocorrem associados à posição dos complementos dos verbos.

Quadro 6 - Os pronomes clíticos ${ }^{69}$

\begin{tabular}{|l|c|c|c|}
\hline Pessoas & \multicolumn{2}{|c|}{ Clíticos não-reflexos } & Reflexos \\
\hline gramaticais & Acusativo & Dativo & Acusativo / Dativo \\
\hline 1. ${ }^{\text {a }}$ singular & me & me & me \\
\hline 2. ${ }^{\text {a }}$ singular & te & te & te \\
\hline 3. ${ }^{\text {a }}$ singular & o/a & lhe & se \\
\hline $1 .^{\text {a }}$ plural & nos & nos & nos \\
\hline 2. ${ }^{\text {plural }}$ & vos & vos & vos \\
\hline 3. ${ }^{\text {p }}$ plural & os/as & lhes & se \\
\hline
\end{tabular}

Ora, essa correlação não é simétrica (cf. Brito, Duarte \& Matos, op. cit. p. 826, 827), pois o uso dos clíticos tanto pode se enquadrar na definição tradicional de pronome pessoal (designando uma das entidades envolvidas no processo de comunicação) como pode denotar um predicado e não uma entidade ${ }^{70}$ :

\footnotetext{
${ }^{69}$ Quadro retirado de Brito, Duarte \& Matos (2003 p. 827, renumerado).

${ }^{70}$ Exemplos retirados de Brito, Duarte \& Matos (2003 p. 827, renumerados).
} 
(18) a. Ele viu-me ontem na praia

b. Simpáticos para nós, eles sempre assim o foram

Em que (18a) denota a entidade participante do discurso (a $1^{\mathrm{a}}$. pessoa) e (18b) denota uma categoria gramatical, no caso, um predicado. Essa parece ser uma propriedade morfossintática específica da categoria pronominal clítica nas línguas românicas (que apresentam clíticos sintáticos).

As propriedades dos clíticos no PE identificadas por B,D\&M (op. cit. p. 835) são arrolados a seguir:

(i) apresentam potencial referencial ou predicativo;

(ii) a possibilidade de receber um papel temático;

(iii) a faculdade da referência específica ou arbitrária;

(iv) a capacidade de ocorrer em construções de redobro de clítico e de extração simultânea de clítico; ${ }^{71}$

(v) a faculdade de funcionar como um afixo capaz de alterar a estrutura argumental de um predicado.

Em função destas propriedades dos pronominais clíticos do $\mathrm{PE}$, eles são classificados na Gramática da Língua Portuguesa em cinco tipos distintos. Esta tipologia é apresentada a seguir:

(i) Clíticos com conteúdo argumental: são os pronominais (não-reflexivos), os anafóricos (reflexivos e recíprocos) e o $\boldsymbol{s}$ e-nominativo.

(ii) Clítico argumental proposicional ou predicativo: o demonstrativo o

(iii) Clíticos quase-argumentais: o se-passivo, os dativos ético e de posse.

(iv) Clítico com comportamento de afixo derivacional: os ergativos/anticausativos.

(v) Clítico sem conteúdo semântico ou morfo-sintático: os clíticos inerentes.

\footnotetext{
71 A Extração Simultânea Clítica foi apontada inicialmente por Kayne (1975) para construções clíticas na língua francesa. A extração ocorre em frases coordenadas onde apenas um único clítico pode recuperar os argumentos aos quais está associado em cada um dos termos coordenados da sentença. Brito, Duarte \& Matos (2003, p. 835) dão exemplos desse tipo de construção em PE:

- Ele tinha-o visto [-] e reconhecido [-] imediatamente

- A Ana estava-lhe sempre a telefonar [-] para casa e a pedir conselhos [-]

- Ele também o vira [-] e reconhecera [-] imediatamente.

- Ele nunca lhe telefonava [-] para casa ou pedia conselhos [-]
} 
Das cinco propriedades apresentadas acima, duas delas parecem não fazer parte da sintaxe do PB: a propriedade do redobro e a extração simultânea de clítico. Na seção deciada ao $\mathrm{PB}$, retomo as propriedades descritas acima.

$\mathrm{Na}$ literatura há diversos trabalhos de análise clítica dos mesmos traços tipológicos apresentados por B,D\&M. Déchaine \& Wiltchko (2002) também captam essas particularidades dos clíticos, além de outras, e propõem uma tipologia bastante abrangente para as pro-formas pronominais, baseada em três diferentes 'comportamentos': pro-DP, pro$\Phi P$ e pro-NP (D\&W, op. cit., p. 419). Elas defendem que pro-DPs são sempre argumentais, pro- $\Phi P s$ são argumentais e/ou predicacionais e pro-NPs funcionam unicamente como predicados.

Em francês, como se pode ver em (19a, c), ocorrem tanto clíticos predicativos pro$\Phi P s$ quanto pro-NPs; já em inglês, língua que não possui clítico sintático (argumental ou predicativo), as autoras apresentam a proforma pronominal one como exemplo de pro-NP cuja função é predicativa, em $(20)^{72}$ :

(19) a. Marie est une avocate, et Jeanne le sera aussi (pro-ФP)

b. J'ai vu [un grand livre]

J'[en] ai vu un grand (pro-NP)

(20) The read $[\mathrm{car}]_{\mathrm{i}}$ is more expensive than the yellow [one $]_{\mathrm{i}}$ (pro-NP)

$\mathrm{Na}$ seção 3.4.9, do capítulo 3, retomo a tipologia proposta por Déchaine \& Wiltchko (2002) relativamente às pro-formas pronominais, face à análise que desenvolvo para as expressões 'esse um / essa uma' que se assemelham à expressão 'the one', do inglês; mas, diferentemente desta, que é exclusivamente pro-NP (predicado), as pro-formas que ocorrem em Jurussaca, conforme demonstrarei nos dados, comportam-se como pro- $\Phi P s$, ou seja, ora funcionam como pro-formas predicativas, ora como pronominais referenciais, como se pode verificar, em $(21):^{73}$

(21) Eu acho que essa uma é que num conta mais nada... porque ela tá muito velhinha (Seu Chico)

Tais assimetrias entre clíticos e pronomes, levaram B,D\&M a afirmar:

\footnotetext{
${ }^{72}$ Exemplos retirados de Déchaine \& Wiltschko (2002, p. 420, 427, 428 e renumerados).

${ }^{73}$ Exemplo retirado de Petter \& Oliveira (2011b).
} 
[...] a inclusão dos pronomes clíticos na classe dos pronomes pessoais, embora pareça formalmente pertinente, não permite estabelecer um paralelo exato entre as formas fortes do pronome pessoal e as formas clíticas, em termos do seu significado e das funções que desempenham.

B,D\&M (2003, p. 827)

A assimetria observada por B,D\&M (op. cit.) é bastante pertinente. O PB, normalmente, licencia uma categoria vazia em lugar do clítico predicativo que ocorre no PE, pois o pronome ele não poderia ser licenciado no lugar do clítico $o$, no exemplo de B,D\&M, em (18 b) acima (simpáticos para nós, eles sempre assim (*eles) foram). Aliás, Galves (2001b, p. 173) observou que a assimetria existente entre um pronome que licencia um predicado e um pronome que não licencia encontra-se na referencialidade - caso do pronome lembrete ele em PB - que só pode receber interpretação referencial. Os exemplos abaixo (de Galves, 2001b), mostram que o pronome não recebe interpretação referencial. O elemento topicalizado e o núcleo da relativa são um sintagma existencialmente quantificado. ${ }^{74}$

(22) a. Alguém (*ele) veio

b. procuro alguém que (*ele) saiba falar inglês

A assimetria observada por B,D\&M torna-se neutralizada ao se considerar, por exemplo, o PVB falado em Jurussca que, normalmente, não utiliza as formas clíticas como complementos verbais. Nesses contextos o emprego das formas tônicas é categórico: $:^{75}$

(23) a. dá uma rebocada, arrumá ela melhor...

b. vô ajeitá ela...

Em complementação à lista de restrições sintáticas, em termos assimétricos, apresentada acima por B,D\&M (op. cit.), Martins (2013, p. 2238) também arrola uma outra assimetria entre os pronomes fortes e os clíticos. Em português eles: (i) não comportam estruturas de coordenação, (ii) nem podem ser modificados por orações relativas. Os exemplos extraídos de Martins (2013), repetidos em (24a)-(25a), mostram as estratégias utilizadas em PE por meio do redobro clítico a fim de se evitar estruturas agramaticais. Note que, em (24b), a agramaticalidade da sentença se dá em função da incompatibilidade de se

\footnotetext{
${ }^{74}$ Exemplos retirados de Galves (2001b, p. 173, renumerados). Galves (2001) defende que o pronome 'ele', nessas construções, funciona como pronome fraco, podendo comportar referência a entidades com traço [+/Humano], mas o mesmo pronome não é licenciado em contextos sintáticos como o isolamento ou construçães de foco.

${ }^{75}$ Exemplos retirados de Petter \& Oliveira (2011b, renumerados).
} 
coordenar um elemento clítico (deficiente) a um DP pleno. No caso de (25b), a agramaticalidade ocorre porque um clítico sofre restrições sintáticas que o impedem de ser o antecedente de uma oração relativa: ${ }^{76}$

(24) a. Dei-lhe [a ele e à irmã] um livro que eles vão adorar.

b. *Dei-[lhe e à irmã] um livro que eles vão adorar.

(25) a. Prefiro- $a$ a ela, que tem melhor feitio.

b. *Prefiro- $a$, que tem melhor feitio.

De fato, pode-se argumentar que esse aspecto assimétrico entre pronomes fortes e clíticos já estava indiretamente inserido na definição clássica de pronome - baseada em modelo binário, mencionado no início do capítulo, uma vez que tal acepção coloca de um lado os pronomes fortes - aqueles que desempenham a função de sujeito - e, de outro pronomes oblíquos - aqueles que desempenham a função de complemento, também inserido na acepção clássica da sintaxe das orações face à dicotomia sujeito vs. predicado ou sujeito vs. paciente. Sobre essa assimetria, vale retomar o argumento de B,D\&M (2003), de que a inclusão dos pronomes clíticos na classe dos pronomes pessoais, "embora pertinente, não estabelece um paralelo exato entre as formas fortes do pronome pessoal e as formas clíticas, em termos do seu significado e das funções que desempenham".

\subsubsection{Clíticos simples e especiais}

O comportamento híbrido dos elementos clíticos tem um longo histórico de descrições iniciadas no bojo dos estudos que desencadearam a linguística históricocomparada do século XIX, focada na gênese do indo-europeu. Mas a tipologia de maior envergadura face à do século XIX foi proposta por Arnold Zwicky (1977): clíticos simples e clíticos especiais. ${ }^{77}$ Nas palavras do autor, as formas clíticas são: "bound unaccented morphemes that sometimes are in construction with affixes" (op. cit., p. 7). Esse estudo é

\footnotetext{
${ }^{76}$ Exemplos retirados de Martins (2013, p. 2238, renumerados).

${ }^{77}$ Zwicky (1977) propõe um terceiro tipo de clítico - as palavras ligadas - itens fonologicamente dependentes com certa liberdade sintática no sentido de cliticizarem-se a uma grande variedade de categorias e que se diferenciam dos clíticos simples e especiais por não estarem relacionados com nenhuma forma plena (um verbo ou um pronome) e podem denotar um significado semântico, morfológico ou fonológico relacionado a um sintagma ou a uma sentença. Zwicky cita como exemplo as formas genitivas reduzidas do inglês: The salesman I warned you about's daughter.
} 
apontado como o primeiro a abordar simultaneamente os clíticos sob os enfoques sintático, morfológico e fonológico. ${ }^{78}$

Para Zwicky, toda palavra que pode aparecer sem acento fonológico tem potencial para cliticizar-se a uma palavra vizinha. Há uma lista de categorias sintáticas com esse potencial em várias línguas, como: auxiliares, modais, verbos em construções perifrásticas, conjunções e complementadores, determinantes, pronomes pessoais, etc. No entanto, Zwicky observa que os pronominais clíticos têm características bastante diferentes das demais formas com potencial clítico. Assim, de um lado estão as formas clíticas 'ordinárias' com características fonológicas opacas e de outro lado formas clíticas com necessidade de 'sintaxe especial'.

(i)

\section{Clítico simples:}

Zwicky (1977) define como clítico simples aquelas unidades que sofrem uma redução fonológica de forma que devem juntar-se à palavra mais próxima e explica que esses elementos ocupam a mesma posição sintática que as formas plenas que as precedem, sendo que, normalmente, seu uso está restrito ao estilo informal da língua falada (são formas estilísticas). Como exemplo de clítico simples, o autor elenca vários elementos: as formas reduzidas dos auxiliares do inglês ' $d$ (forma reduzida de would ou had); a redução de to que ocorre em I wanna go; a redução de one, em big'un e this'un; a redução de 'not', em Haven't, etc.

\section{Clíticos especiais}

Os clíticos especiais são itens que substituem Expressões Referenciais e PPs - e cujas formas não acentuadas exibem 'sintaxe especial' ao serem cliticizadas; ocorrem como variantes de formas livres. O exemplo que ilustra esse comportamento é dado pelos clíticos pronominais românicos os quais são considerados por Zwicky (1977) pronomes que sofreram

\footnotetext{
${ }^{78}$ Camacho (2006, p. 24) remonta as primeiras referências sobre os clíticos, presentes na história da linguística, aos trabalhos dos filólogos alexandrinos Zenódoto, Aristarco de Samotracia, Comano e Dionísio de Trácia, mas, para a autora, é somente no século XIX, com os estudos histórico-comparados sobre os sistemas linguísticos dos romances, em vista às origens do indo-europeu, que surgem as primeiras descrições dos clíticos como unidades linguísticas com características especiais. Dentre esses estudos, Camacho cita a Grammatik der Romanischen Sprachen de Friederich Diez e os trabalhos de Adolf Tobler (1875, 1889) e Mussafia (1898) com descrições reguladas por princípios fonéticos que estabeleciam um padrão regular de colocação clítica nas línguas românicas medievais: a segunda posição na oração (posição P2) ou posição pós-verbal obrigatória, na ausência de material fonético antes do verbo. A partir de então, os estudos sucessivos seguiram a linha que ficou conhecida como Lei Tobler-Mussafia.
} 
uma redução ou deficiência fonológica e que ocupam uma posição sintática distinta da canônica.

Um exemplo de clítico especial são as formas pronominais que exibem padrão 'especial' de colocação em próclise ao predicador verbal, em quase todas as línguas românicas (exceto o PE). Em francês, por exemplo, DPs objeto normalmente seguem o verbo e as formas clíticas o antecedem: ${ }^{79}$

(26) a. Marie connaît mon frère

b. Marie nous connaît

Outro exemplo de clítico simples, agora do português, em que a maior parte desses elementos cliticizam-se à palavra acentuada que ocorre imediatamente à sua direita, é o que acontece com o artigo definido a no sintagma nominal a casa, sendo, portanto, proclíticos simples; os pronomes pessoais quando se cliticizam encliticamente apresentam um comportamento sintático particular entre as formas clíticas, o que motiva a sua classificação como clíticos especiais.

Os clíticos são, portanto, no quadro proposto por Zwicky (1977), elementos fonologicamente ligados a um hospedeiro que, dependendo de seu comportamento em cada um dos níveis linguísticos, podem ser caracterizados como clíticos simples, cujo comportamento na morfologia e na sintaxe é o canônico, e clíticos especiais que necessitam de uma sintaxe especial.

\subsubsection{Diferenças estruturais clíticas nas línguas românicas}

Nas seções anteriores apresentei a tipologia dos pronomes clíticos em português, bem como algumas assimetrias entre eles e os pronomes tônicos. Nesta seção abordo o comportamento dos clíticos face a outras línguas, e, em seguida, apresento algumas propostas de análise e projeção dos pronomes clíticos em língua portuguesa, presentes na literatura.

O comportamento dos pronomes clíticos não é unânime nas línguas românicas. O padrão de colocação desses pronomes é, aliás, bastante variável, o que faz com que as análises presentes na literatura proponham diferentes estruturas para essas línguas. Esses

\footnotetext{
${ }^{79}$ Exemplos retirados de Kayne (1975, p. 66 e renumerados).
} 
estudos abordam questões que têm sido levantadas desde os trabalhos pioneiros de Kayne (1975, 1991). Entre as principais questões levantadas pelas análises, estão:

(i) os clíticos têm comportamentos diferentes dos DPs lexicais no que se refere às suas propriedades de colocação e de movimento;

(ii) eles não compartilham as mesmas propriedades de colocação no domínio nas línguas românicas;

(iii) as múltiplas propriedades dos clíticos ora como núcleos $\left(\mathrm{X}^{0} \mathrm{~s}\right)$, ora como categorias sintagmáticas, com projeções altas (DPs) ou (NPs) são propriedades com alto grau de variação entre as línguas.

Sobre as três propriedades mencionadas acima, é importante observar que elas refletem noções captadas no quadro teórico da Gramática Gerativa. Os pronomes tônicos e os clíticos não têm o mesmo estatuto quer na acepção mais recente do Programa Minimalista, quer no quadro teórico do modelo P\&P, da Teoria de Regência e Ligação. Galves (2001a, p. 138), citando (Kayne, 1991), aponta que no quadro teórico do modelo de $\mathrm{P} \& \mathrm{P}$ distinguem-se as categorias de nível sintagmático (sintagmas ou phrases) e as categorias nucleares (núcleos ou heads). Os pronomes tônicos são itens lexicais e, portanto, pertencem à categoria phrases, assim como os DPs/NPs, daí a terminologia corrente pronome lexical - e, assim como os nomes, são XPs ou projeções máximas; já os clíticos (sintáticos, nos termos de Zwicky, 1977) são analisados como núcleos (cf. Kayne, 1991 - ver proposta de Kayne na subseção, a seguir, 2.4.3.1) e, uma vez que são núcleos, eles não são XPs mas $\mathrm{X}^{0} \mathrm{~s}$. Naquele quadro teórico, a 'Estrutura Superficial' das sentenças contendo pronomes lexicais exibe-os em posições argumentais de sujeito ou objeto, enquanto os clíticos são afixados ao núcleo verbal em $\mathrm{I}_{\mathrm{NFL}} \mathrm{e}$, portanto, numa projeção derivada.

Galves (op. cit.) acrescenta que, sintaticamente, nas línguas românicas, de modo geral, os pronomes tônicos ocupam a posição de sujeito e de complemento de preposições, enquanto os pronomes clíticos correspondem aos argumentos internos dos verbos (acusativos e dativos), podendo também corresponder a funções como: genitivo, locativo, benefactivo, etc. Todavia, o PB e, mais intensamente, o PVB fugirão à regra quanto ao padrão românico, introduzindo pronomes não clíticos como complementos verbais acusativos e dativos.

No modelo minimalista, (cf. Chomsky, 1995, 1999b) as categorias pronominais tanto XPs quanto $\mathrm{X}^{0} \mathrm{~s}$ são elementos compostos por traços- $\varphi$. Os pronominais clíticos 
manifestam seus traços- $\varphi$ na sintaxe como categoria funcional (poderiam até ser considerados morfemas devido às suas características sintáticas e fonológicas - proposta de alguns autores, como Everett (1994)). Os itens lexicais - XPs - têm traços fortes e precisam ser verificados antes de Spell-out; já os itens $\mathrm{X}^{0} \mathrm{~s}$ têm seus traços fracos e são verificados depois de Spell-out, em LF. ${ }^{80}$

Assim, os pronomes lexicais ocorrem em estruturas sintáticas de base e os clíticos em estruturas derivadas e com graus de relativização entre as línguas. No domínio das línguas românicas, por exemplo, o padrão de colocação dos clíticos é a próclise e a ênclise ao verbo, seu hospedeiro. ${ }^{81}$ Em regra geral, os clíticos do PB, assim como os do espanhol, os do italiano e os do francês têm como principal propriedade a próclise. No entanto, no italiano e no espanhol a próclise ocorre em orações finitas e a ênclise em orações infinitivas. No francês os complementos clíticos são sempre proclíticos, com exceção do imperativo afirmativo. ${ }^{82}$ No PE, o padrão de colocação é a ênclise, tanto em orações finitas quanto não finitas. Nessa língua, a derivação da próclise ocorre na presença de um operador - elemento que c-comanda o hospedeiro do clítico (cf. Duarte \& Matos, 2000).

Mas onde há semelhanças também há muitas diferenças. No PB, a colocação préverbal dos clíticos pronominais assemelha-se à das línguas citadas anteriormente (espanhol, italiano e francês), no entanto distancia-se dessas línguas em muitos aspectos. A próclise, em PB, ocorre geralmente ao verbo principal (que atribui papel temático - cf. Galves (2001, p. 135)) e, por essa razão, normalmente, não permite a afixação dos clíticos aos auxiliares e modais (contextos universais de subida de clítico nas línguas românicas). ${ }^{83} \mathrm{E}$ essa restrição do PB é a responsável pela ausência de construções de subida de clítico na língua (cf.

\footnotetext{
${ }^{80} \mathrm{Na}$ literatura há diferentes concepções sobre os traços funcionais dos clíticos serem fortes ou fracos. Uriagereka (1992), por exemplo, propôs uma divisão dos clíticos em fortes (os de $1^{\mathrm{a}} \mathrm{e} 2^{\mathrm{a}}$ pessoas) e fracos (os de $3^{\text {a }}$.pessoa) cujos traços serão fortes e fracos, respectivamente.

81 No PE, a mesóclise é o padrão alternativo para a ênclise em orações com tempo nas formas futuro ou condicional (futuro do pretérito) e ocorre em distribuição complementar em relação à ênclise. No entanto, diferentemente do que faz crer muitos manuais de ensino de português, o fenômeno da mesóclise não é a colocação de um pronome clítico no meio de um verbo ou entre um verbo e um de seus morfemas, pois, diacronicamente, ela se formou como a colocação de um clítico entre dois verbos (principal e auxiliar), como se pode verificar em ocorrências constatadas em jornais brasileiros do século XIX: "FESTA DE Nossa Senhora D'AJUDA \| Celebrar-se-ha no corrente anno, | com o esplendor do costume, a fes|ta da Excelsa Virgem Nossa Senho|ra d'Ajuda. || No domingo 14 effectuar-se ha o | bando de mascaras (...)" (Guedes e Berlinck. 2000, p. 33). Sobre mesóclise como resíduo de uma gramática antiga, ver Brito, Duarte \& Matos (2003, p. 865-67).

${ }^{82}$ Para Cardinaletti e Starke (1999), no imperativo afirmativo do francês ocorre um pronome fraco e não um clítico.

${ }^{83}$ As construções de Clitic Clymbing (Rizzi, 1978, 1982), ocorrem quando um pronominal clítico associa-se a um verbo do qual não é complemento, geralmente verbos auxiliares e modais.
} 
Cyrino, 2010), ${ }^{84}$ o que cria algumas assimetrias em relação ao PB e às demais línguas românicas:

(i) a restrição à subida de clítico distancia o PB do italiano e do PE (línguas de sujeito nulo) que permitem a subida de clítico,

(ii) a mesma restrição aproxima o PB do francês que não aceita o sujeito nulo nem permite o movimento clítico, mas afixa o clítico aos auxiliares (cf. Galves 2001, p. 139), ${ }^{85}$

(iii) O PB também se distancia do francês que afixa os clíticos aos auxiliares e não ao verbo principal.

Segundo Galves (2001a, p. 139), é a mudança ocorrida no francês em relação à cliticização pronominal aos verbos auxiliares que explica a perda do parâmetro pro-drop nesta língua - fato que não pode ser usado para o PB para explicar as mudanças em curso quanto à "perda" do parâmetro pro-drop. ${ }^{86}$

Na próxima seção, menciono algumas propostas para análises clíticas vigentes na literatura, sob diferentes prismas: sintático, morfológico e fonológico.

\subsubsection{Possibilidades de análises clíticas: algumas propostas vigentes na literatura}

Nesta seção, dividida em três subseções, apresento brevemente algumas propostas teóricas de análise dos pronominais clíticos presentes na literatura, cuja abordagem se dá sob diferentes prismas: sintático, morfológico e fonológico ou prosódico. As línguas têm especificidades relativamente aos elementos pronominais clíticos e diferentes propostas surgiram sob possibilidades diferentes de análise, uma vez que um único critério

\footnotetext{
${ }^{84}$ Há certas construções de tempo composto onde pode ocorrer próclise a auxiliares, como nas locuções com auxiliares mais particípios, por exemplo:

(1) Você tem visto o João?

Sim, eu o tenho visto quase diariamente!/ Não, eu não o tenho visto ultimamente!

Sintaticamente, essa colocação clítica distingue-se da que ocorre nas tradicionais construções de subida de clítico românicas em construções de predicado complexo ou de reestruturação.

85 O movimento clítico mencionado por Galves (2001a) não é o mesmo que subida de clítico, mas um fenômeno que ocorre em certas construções sintáticas com modais e aspectuais. Um exemplo dessa construção no PE é oferecida pela autora: "E começamo-nos a detestar" (GALVES, 2001a, nota 16, p. 151).

${ }^{86}$ Quanto ao parâmetro pro-drop, o PB é considerado língua de sujeito parcialmente nulo - ver (KATO, 1999) entre outros.
} 
normalmente não dá conta das especificidades que as línguas apresentam. Mesmo entre as românicas não há homogeneidade quanto às operações de colocação clítica.

É importante salientar que o padrão de colocação clítico românico não é o único. $\mathrm{Na}$ literatura (cf. Renzi, 1989) há descrições de dois tipos: (i) o adverbal românico ' $\mathrm{Cl}-\mathrm{V}$ ' (presente também em línguas indo-europeias da região dos Bálcãs), com adjunção dos clíticos pronominais - daqui em diante, ClsPrns - ao verbo (ou, de modo mais amplo, em adjacência a uma categoria do domínio flexional); e (ii) o padrão P2, com distribuição muito ampla. A característica distintiva dos clíticos $\mathrm{P} 2$, face aos clíticos adverbais, é sua ocorrência logo após o complementizador, como se pode verificar nos exemplos abaixo (no contraste entre os itens sublinhados no servo-croata e no macedônio; “|” demarca o início da oração): ${ }^{87}$

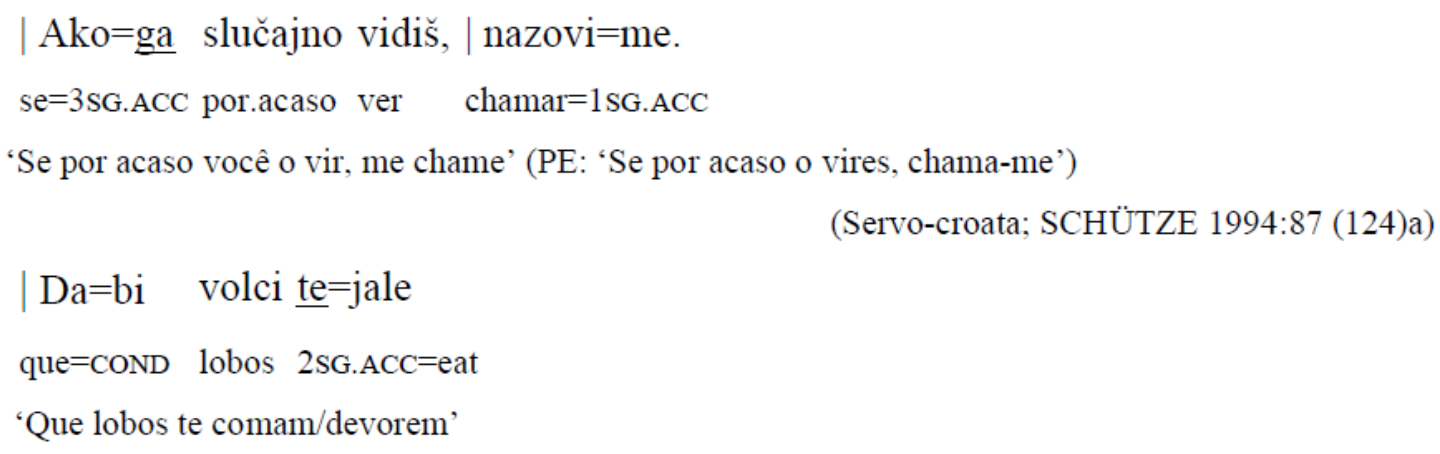

(Macedônio; FRANKS \& KING 2000:77 (128))

Segundo Andrade (2010, p. 107), vários estudos têm apontado que as línguas românicas medievais eram sistemas com clíticos $\mathrm{P} 2$ que se transformaram em $\mathrm{Cl}$ - $\mathrm{V}$ (ou adverbais). Esses estudos levantam a tese de que o fenômeno da interpolação, disseminado no português clássico e ainda presente no PE (em alguns dialetos, cf. Martins (2013, p. 2233) constitui uma situação intermediária entre clíticos P2 e clíticos adverbais.

Uma outra questão relativamente à distinção entre clíticos $\mathrm{P} 2$ e clíticos adverbais está relacionada à sua complexidade estrutural, no sentido de serem tratados como $\mathrm{X}^{0} \mathrm{~s}$ ou XPs. Mais uma vez, há implicações teóricas e hipóteses bastante divergentes na literatura sobre os clíticos $\mathrm{P} 2$ serem núcleos ou sintagmas, assim como os clíticos adverbais românicos que são classificados como $\mathrm{X}^{0} \mathrm{~s}$ (Kayne, 1991), ${ }^{88}$ já que no modelo minimalista (cf. Chomsky, 1995, 1999b) as categorias pronominais XPs e $\mathrm{X}^{0} \mathrm{~s}$ são elementos compostos por

\footnotetext{
${ }^{87}$ Exemplos retirados de Andrade (2010, p. 107).

${ }^{88}$ Uma implicação teórica diretamente ligada ao paralelismo entre movimento de XP e de $\mathrm{X}^{0}$ será a eliminação da Restrição sobre movimento de núcleos.
} 
traços- $\varphi$ e o que distingue os ClsPrns dos elementos lexicais será a possiblidade de verificação sintática de seus traços- $\varphi$ antes ou depois de Spell-out.

\subsubsection{Propostas voltadas ao estatuto sintático}

Os trabalhos de Kayne $(1975,1989,1991)$ foram pioneiros no tocante à análise dos ClsPrns nas línguas românicas sob o ponto de vista sintático. Kayne (1991) propôs a seguinte operação de movimento, resultante de duas posições: (i) uma posição temática onde o clítico é gerado e, (ii) em seguida, numa operação de movimento, o clítico é adjungido (em adjunção sempre à esquerda) a seu hospedeiro (o verbo finito) em $\mathrm{I}^{0}$ :

Pronominal clitics in Romance may either precede or follow the verb they are associated with, depending on a number of factors, some of which I shall try to elucidate in this article. My analysis will take Romance clitics to invariably left-adjoin to a functional head. In cases where that functional head dominates the verb, this will straightforwardly yield the order cliticverb. The order verb-clitic will, on the other hand, be claimed to result from the verb's having moved leftward past the functional head to which the clitic has adjoined (rather than having the clitic right-adjoin to the verb). ${ }^{89}$

(KAYNE, 1991, p. 647)

Nos termos de Kayne, toda adjunção a uma categoria $\mathrm{X}^{0}$ deve ser à esquerda (op cit. p. 649). Em suas análises para o italiano e o francês, em construções finitas, o pronome clítico adjunge-se regularmente à esquerda de I (Cl-I); em casos de sentenças encaixadas não finitas, o italiano não permite a ordem $\mathrm{Cl}-\mathrm{V}$ e, nessa construção, o clítico está adjungido também a I. No entanto, o verbo move-se à esquerda, passando por I e ocupando uma posição mais alta, em adjunção a I' (I-barra), conforme a representação de Kayne, repetida abaixo:

$$
(27) \ldots \mathrm{V} \ldots \mathrm{Cl}+\mathrm{I} \ldots[\mathrm{vp}[\mathrm{v} \mathrm{e}] \ldots] \ldots{ }^{90}
$$

\footnotetext{
${ }^{89}$ Tradução aproximada: “Os clíticos pronominais nas línguas românicas podem tanto preceder quanto seguir o verbo ao qual estão associados, a depender de uma série de fatores, alguns dos quais eu tentarei esclarecer neste artigo. Minha análise conceberá os clíticos românicos como adjunção à esquerda a um núcleo funcional, invariavelmente. Nos casos em que o núcleo funcional domina o verbo, isso vai produzir diretamente a ordem clítico-verbo. A ordem verbo-clítico será, por outro lado, o resultado do movimento do verbo para a esquerda, passando pelo núcleo funcional ao qual o clítico se adjungiu (ao invés de o clítico ter se adjungido à direita do verbo)".

${ }^{90}$ Representação retirada de Kayne (1991, p. 649, renumerada).
} 
A proposta de Kayne (1991) capta bem a relação com a posição temática do complemento verbal clítico. No entanto, como se sabe, há casos em que pronominais clíticos não têm nenhum papel temático - como nas construções de redobro clítico, ${ }^{91}$ clítico inerente e éticas. ${ }^{92}$ Nesses casos, a proposta de Kayne, baseada em operação de movimento, não capta essas ocorrências clíticas nas quais os ClsPron não têm papel temático, construções essas muito comuns no PAfro-indJ e nos falares urbanos e rurais de modo geral:

(28) a. ... ele já ia e insurtava o pessoal que passavam no gapó... deu-lhe numa senhora pra lá.... deu-lhe noutra, derramou o açaí duma mulher por lá... ${ }^{93}$ b. [...] Eu vou dá-lhe na sua cara! ${ }^{94}$

As construções em (28) acima são comuns na comunidade de Jurussaca e ocorre com certa frequência nas narrativas registradas nos corpora que ora investigo para esta tese. No entanto, a proposta de análise desses itens clíticos em adjunção a V na posição temática, seguido de movimento de adjunção à esquerda de I, de Kayne, não comporta construções do tipo 'dativas éticas' (ou de 'clítico inerente') como as apresentados em (28a, b).

Sobre clítico inerente ainda é pertinente acrescentar que alguns autores assumem para essas construções a tese do movimento, como a proposta de Bonet (1991) para o catalão, com base na proposta de movimento de clítico de Kayne:

In many cases these clitics affect the argument structure of the verb or they alter its abilty to assign Case. Moreover, in some cases the verb does not exist without the clitic. I will assume, with Kayne (1975), and later works, that these clitics are nevertheless generated in argument position, and that they adjoin to Infl in the syntax..$^{95}$

(BONET,1991, p. 61)

\footnotetext{
${ }^{91} \mathrm{Na}$ literatura há diversas propostas para análise das construções de redobro de clítico, como Everett (1996), para o português Martins $(1996,2013)$.

92 Os dativos livres são considerados por Bechara (2009, ps. 423-424) como “(...) argumentos sintáticosemânticos extensivos da função predicativa do conteúdo das orações"; em outras palavras, dativos livres são NPs ou PPs sem papel temático. O autor dá como exemplo, entre outros: o dativo ético: "Não me reprovem essas ideias", o dativo de opinião: "para nós ela é a culpada", o dativo de posse "Doem-me as costas" etc.

${ }^{93}$ Exemplo retirado de PETTER \& OLIVEIRA (2011d, numerado).

${ }^{94}$ Exemplo fornecido por Márcia Oliveira de uma fala do português de São Luís (MA) - o contexto são duas mulheres da periferia discutindo em via pública. O exemplo enquadra-se nos falares urbanos não-padrão [marcados], conforme o continuum de português proposto no capítulo 1 , seção 1.5. Chamo ainda a atenção para o fato de que o exemplo (27b) é amplamente atestado no PVB urbano em sentenceas como: (i) Dá-lhe Coríntians! (em São Paulo).

${ }_{95}$ Tradução aproximada: "em muitos casos esses clíticos afetam a estrutura argumental do verbo ou eles modificam sua habilidade de atribuir Caso. Além disso, em alguns casos o significado do verbo é modificado. Em outros casos o verbo não existe sem o clítico. Assumirei com Kayne (1975), e em trabalhos mais recentes, que esses clíticos, ainda assim, são gerados em posição argumental e que eles se adjungem a Infl na sintaxe".
} 
Mas o mesmo não se aplica para o clítico ético, pois, "Ethicals never play a syntactic role" (op. cit. p. 63) e, para Bonet, eles parecem estar mais ligados ao discurso:

Contrary to Borer \& Grodzynsky (1986) I do not assume that the insertion of ethicals is a lexical process (they do not have any effect on the syntax, and they do not alter the argument structure of the verb or anything else related to it). These clitics seem to be mainly discourse-related. In any case they are very different from other uses of clitics presented earlier. ${ }^{96}$

(BONET, 1991, p. 64)

Também é interessante observar que no dialeto falado na comunidade de Jurussaca (e também em Belém) alguns verbos possuem em sua grade clíticos inerentes que diferem os mesmos dos do português padrão:

(29) Hoje eu me acordei tarde. ${ }^{97}$

Dada a possibilidade de ocorrência em variação relativamente ao verbo acordar em pronominal vs. não pronominal, talvez seja o caso de elencar esse tipo de ocorrência de clítico inerente aos casos de clítico ético, nos termos de Bonet (op. cit, p. 64): em que clíticos éticos estariam mais relacionados a questões discursivas do que sintáticas. Assim, a ocorrência em (29) poderia ser tratada, sintaticamente, como um caso de geração na base e não propriamente consequência de movimento.

Outra possibilidade para uma análise que contemple essas construções, seria a proposta alternativa de autores como Borer (1981), Sportiche (1993), entre outros, que, diferentemente da de Kayne, não aplica movimento; o clítico seria gerado em Infl. Essas propostas ficaram conhecidas como geração na base (base-generated). Borer (op cit.) propõe que os clíticos são gerados na base em Infl e coindexados com uma categoria vazia pro na posição temática. ${ }^{98}$

\footnotetext{
${ }^{96}$ Tradução aproximada: “Ao contrário de Borer \& Grodzynsky (1986) eu não assumo que a inserção de éticos seja um processo lexical (eles não têm qualquer efeito sobre a sintaxe, e eles não alteram a estrutura argumental do verbo ou qualquer outra coisa relacionada a ele). Estes clíticos parecem estar relacionados ao discurso. Em qualquer caso, eles são muito diferentes de outros usos de clíticos mencionados anteriormente"

${ }^{97}$ Borba (2004, p.19) registra as seguintes entradas para acordar: (i) Vt 1 = tirar do sono, despertar: Desculpe, eu não queria acordar você; $\mathbf{2}(+\mathrm{de})=$ voltar a si, sair: Quando acordou daquele entorpecimento, percebeu que já escurecia; 3 (+para) = tomar consciência, despertar: Os partidos já acordaram para a necessidade de orientação dos eleitores; Vi $\mathbf{4}$ = sair do sono, despertar: Quando acordou, a visita já tinha ido embora; $\mathbf{5}=$ iniciar: Pela manhã: os ruídos característicos da vida que acorda e (ii) Vt $(+\mathrm{em} / \mathrm{sobre})=$ pôr-se de acordo: Todos acordaram em que Tio Lourenço resolvesse tudo.

98 Para Andrade (2010, p. 106) essa proposta é problemática uma vez que se depara com uma questão de ordem conceitual ligada à formação de cadeias do tipo núcleo-XP, pois um clítico redobrado, por exemplo, teria relação com um NP lexical, e não com um pro.
} 
A título de exemplo, apresento as representações das propostas de Kayne e Borer oferecidas por Andrade (2010): ${ }^{99}$
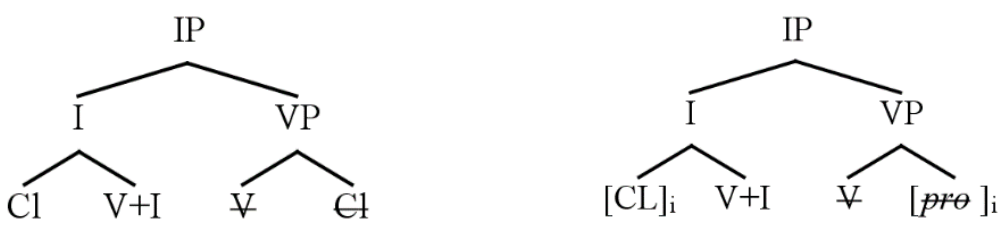

A geração na base de Borer (1981), como já mencionado, permite explicar porque clíticos éticos e/ou inerentes não fazem referência a nenhum argumento temático.

Uma diferença crucial entre a primeira proposta (Kayne) e a segunda (Borer) está no estatuto categórico do clítico, pois na proposta de Kayne, o clítico seria um $\mathrm{D}^{0}$, mas não fica claro qual o seu estatuto na proposta de Borer. É possível hipotetizar que o clítico, para Borer, tenha comportamento similar ao de um morfema (pronomes clíticos seriam similares a afixos ou morfemas de concordância), ${ }^{100}$ apesar de estar sintaticamente coindexado a uma categoria pro em V (cf. 29b).

Ainda outra questão que se coloca relativamente à possibilidade de análise dos ClsPron como operação resultante de movimento (cf. (30), acima) diz respeito à ligação (estreita) do clítico com o seu hospedeiro verbal, pois na linha adotada por Kayne, o complexo [clítico + verbo] é gerado inicialmente em posição de adjunção ao núcleo V; e, por outro lado, no âmbito da TRL, alguns autores como Laka (1991) e Roberts (1993) propuseram a geração de afixos flexionais como núcleos de suas próprias projeções funcionais, e ligados à raiz verbal, como resultado de movimento de núcleo.

\subsubsection{Propostas referentes ao estatuto morfológico}

Relativamente ao estatuto morfológico dos ClsPrn, há propostas diferentes para eles: Everett (1996, p. 16) inicialmente levanta a questão de que os pronomes $\{$ he, his e

\footnotetext{
99 Representações arbóreas retiradas de Andrade (2010, p. 106, renumeradas); os nomes dos autores foram acresentados por mim.

100 Minha "percepção" de que para Borer (1981) o clítico seja um morfema e não um D0/DP dá-se em função de que este elemento seja gerado diretamente no nó funcional - logo um morfema do tipo funcional.
} 
him \}, do inglês, sejam alomorfes distintos entre si por Caso e pelos traços formais que eles carregam (ou que são valorados). Desse modo, ele argumenta que pronomes são epifenômenos e seus traços- $\varphi$ são armazenados indistintamente no léxico, sendo inseridos em posições sintáticas cujas regras de spell-out em PF vão interpretá-los como pronomes, clíticos (clíticos especiais) ou afixos (clíticos simples), a depender da configuração em que eles se encontram (op. cit. p. 39).

Assim como Kayne, Everett (op. cit. p. 20) defende que clíticos sejam adjungidos em $\mathrm{X}^{0}$ já que clítico é uma categoria Agr e como um Agr pode aparecer como o complemento de um predicado verbal (verb stem), mas em posição Agr que não é msubcategorizado (subcategorizado morfologicamente) e por isso só pode aparecer em $\mathrm{X}^{0}$ via adjunção. Os clíticos especiais seriam categorias pronominais adjungidas via sintaxe. Portanto, para Everett, os traços- $\varphi$ são [+nominal] e [+funcional], sendo que apenas dois locais de inserção são possíveis: $\mathrm{AGR}^{0}$ e $\mathrm{D}^{0}$. Assim, pronomes são traços- $\varphi$ na posição $\mathrm{D}^{0}$; clíticos são traços- $\varphi$ em $\mathrm{AGR}^{0}$, adjungidos na sintaxe ao $\mathrm{X}^{\mathrm{m}}$ (= projeção máxima ou $\mathrm{XP}$ ) e afixos são traços- $\varphi$ em $\mathrm{AGR}^{0}$, incluídos dentro de $\mathrm{X}^{0}$. Os clíticos são, para Everett, adjuntos e os afixos complementos a $\mathrm{X}^{0}$. A proposta de Everett parece assemelhar-se à de Borer (1981) no sentido de conceber a colocação clítica com um caso de geração na base.

A proposta de Everett é bastante interessante para os casos de pronomes sem papel temático relativamente às construções éticas e também de redobro clítico e clítico inerente. As construções frequentes em Jurussaca, apresentadas em (27) e (28), poderiam estar inclusas no estatuto de afixos de Everett, mas no sentido de afixos não argumentais. Não seriam, portanto, complementos, mas traços- $\varphi$ inseridos diretamente em $\mathrm{AGR}^{0}$.

De Cat (2002) faz um estudo dos ClsPrn sujeitos nas variedades do francês falado na Bélgica, Canadá e França e condena uma análise puramente sintática para essas variedades de francês. Propõe que os clíticos pronominais do francês coloquial sejam afixados via geração na base.

I argue ( $(5.1)$ that an analysis attempting to capture the properties and the distribution of French dislocations entirely in the syntax (along the lines of Rizzi 1997, for instance) is not only doomed to require a series of ad hoc stipulations but also makes erroneous predictions. On the basis of spontaneous data and elicited judgements, I show that dislocated structures are not sensitive to islands in spoken French and argue that the most adequate analysis is in terms of adjunction by base-generation. ${ }^{101}$

101 Tradução aproximada: "Defendo ( $\$$ 5.1) que uma análise que tente captar as propriedades de distribuição e deslocamento (dos ClsPrn) franceses inteiramente por meios sintáticos (como o faz Rizzi (1997), por exemplo) está condenada não só a fazer uma série de estipulações ad hoc, mas também a fazer previsões equivocadas. 
(De Cat, 2002, p. 17)

Já Auger (1994) analisa os ClsPrn no francês coloquial de Québec. A autora tem por base os seguintes questionamentos: (i) os ClsPrn nessa variedade são melhor analisados como clíticos sintáticos, clíticos fonológicos, elementos incorporados ou afixos verbais ligados ao verbo? e (ii) eles funcionam como marcadores de concordância (afixos) ou mantêm status de argumento? A autora assume a noção tradicional de afixo e clítico: afixos são elementos morfológicos e clíticos são unidades sintáticas (cf. Zwicky, 1977). Afixos são, portanto, 'anexados morfologicamente' à raiz verbal antes da inserção lexical e não estarão disponíveis para serem movidos ou apagados, nos termos da Hipótese Lexicalista, ${ }^{102}$ que impede que a sintaxe 'manipule' elementos subcategorizados ainda no léxico.

Auger também propõe que as formas verbais são geradas diretamente por processos morfológicos (embora estes processos não sejam explicitamente definidos) e argumenta que nenhum modelo precisa ser postulado para as derivações do francês. Ela assume que clíticos objetos franceses carregam um traço de Caso (para explicar o fato de que redobro de clíticos é agramatical em francês) e que os clíticos sujeitos franceses não comportam/carregam nenhum traço de Caso. Clíticos objeto são, portanto, incluídos no rol dos afixos, enquanto os clíticos sujeitos são concebidos como morfemas de concordância ou afixos.

Cardinaletti \& Starke (1999) transitam entre o estatuto morfológico e o sintático dos clíticos (pautados nas restrições semânticas e fonológicas). Eles propuseram a tripartição da classe de pronomes em elementos fortes, fracos e clíticos. De acordo com a proposta desses autores, os pronomes fracos e fortes ocupam posições de $\mathrm{XP}$, enquanto os clíticos ocupam posições $\mathrm{X}^{0}$. Os elementos fracos e clíticos são deficientes, por isso, são restringidos com relação a sua distribuição, isto é, nenhum deles é coordenável, enquanto os pronomes fortes o são. Pode-se explicar esta diferença estrutural com base na presença versus ausência de um conjunto de núcleos funcionais. Os pronomes fortes, mais robustos, para além dos traços- $\varphi$, portam traços referenciais. Assim, uma classe é um subconjunto morfossintático da outra e, com isso, há uma assimetria morfológica entre as três classes, hierarquicamente organizadas, conforme pode ser visto abaixo em (31), em que os pronomes fracos são deficientes em

Com base nos dados espontâneos e nos julgamentos por elicitação, eu mostro que as estruturas deslocados não são sensíveis a ilhas no francês falado e argumento que a análise mais adequada é a adjunção por geração de base".

102 A Hipótese Lexicalista (CHOMSKY, 1970) estabelece a possibilidade de se representar as relações entre palavras na esfera do próprio léxico. Nesse sentido, a morfologia derivacional é a parte da gramática que dá conta da competência do falante nativo no léxico de sua língua. Portanto, o léxico é compreendido como parte da competência linguística, em oposição à visão tradicional do léxico como vocabulário. 
relação aos pronomes fortes; os clíticos são deficientes em relação aos pronomes fracos. Cada classe compartilha a propriedade de deficiência da sua classe superior e acrescenta novas deficiências: ${ }^{103}$

(31) clitic $<$ weak $<$ strong

(clítico < pronome fraco < pronome forte)

O fato de os pronomes comportarem-se como fortes e deficientes é explicado por C\&S relativamente à distinção semântica face ao traço [+/-Humano] dessas formas. Eles consideram ser este um aspecto universal da tipologia pronominal das línguas e, como exemplo, comparam dados do italiano e do francês, conforme (32 a, b), abaixo: ${ }^{104}$

(32) a.

a. Esse (*e quelle accanto) sono troppo alte.

b. Loro ( e quelle accanto) sono troppo alte. 3.pl.fm.nom (and those besides) are too tall/high

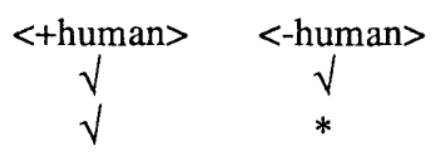

b.

a. Elles

b. Elles et celles d'à côté

sont trop grandes. sont trop grandes.

$\sqrt{ }$
$\sqrt{ }$

$\sqrt{ }$

Nos exemplos em (32a), de C\&S, os pronomes nominativos de terceira pessoa plural 'Esse' (elas) e formal 'Loro' (Srs. Sras.) do italiano permitem observar a seguinte distinção: 'Esse' pode tanto ter referentes humanos quanto não humanos, no entanto, não permite a coordenação; por outro lado, 'Loro' [+Humano] permite a coordenação de referentes. Já o pronome francês 'elles' feminino plural de terceira pessoa, em (32b), também elenca as mesmas restrições, o que parece se tratar de duas classes distintas, porém homófonas, não permitindo uma distinção fonológica como a observada para o italiano. Para os autores, entre as formas que permitem a coordenação e as que não permitem, há um traço formal [+Humano] que as distingue, opondo-se, como já mencionado, de um lado formas fortes e, de outro, formas deficientes.

A proposta de C\&S poderia ser assim resumida:

\footnotetext{
${ }^{103}$ Retirado de Cardinaletti \& Starke (1999 p. 26, exemplo 143, renumerado).

${ }^{104}$ Exemplos retirados de Cardinaletti \& Starke (1999 p. 41, 42), renumerados. Tradução livre: "Ela (*e aquela ao lado) são muito altas" / "Elas (e aquelas ao lado) são muito altas"
} 
do ponto de vista morfo-semântico, pronomes fortes e deficientes quando comparados em construções coordenadas mostram resultados que apontam para a existência de formas homófonas cujo traço distintivo é [ \pm Humano].

(ii) do ponto de vista sintático, a classe de pronomes deficientes obedece a uma generalização empírica, descrita pelos autores como "assimetria sintática", resumida por eles do seguinte modo:

- posição $\theta / o u$ posição de base (em que os pronomes deficientes não podem ocorrer em posições temáticas, ou de base, devendo ocorrer em uma posição especial derivada);

- posições periféricas (pronomes deficientes, diferentemente dos fortes e dos sintagmas nominais, não podem aparecer em posições periféricas como clivagem, deslocamento à esquerda ou à direita e isolamento).

- c-modificação, coordenação (pronomes deficientes não comportam modificações no DP (como as que ocorrem com os advérbios altos, em CP) nem coordenação).

Finalmente, os autores chegam à conclusão de que o estatuto semântico dos pronomes e a assimetria distribucional dos mesmos está relacionada aos seguintes fatores: pronomes fortes precisam sempre ter uma restrição em relação à sua referencialidade; devem ter um escopo (range), face às possibilidades de correferência (anafórica ou disjunta). $\mathrm{Na}$ falta de um, seu escopo default é [+humano]. Os pronomes deficientes, no entanto, são incapazes de carregar uma restrição de escopo própria, por isso podem e devem ser anafóricos, expletivos, impessoais ou dativos éticos.

Para identificar uma entre as duas classes de pronomes deficientes, Cardinaletti e Starke (1999) mostram que a categoria sintática destes elementos difere: enquanto os clíticos são cabeças de uma cadeia $\mathrm{X}^{\mathbf{o}}$, os pronomes fracos são analisados como sintagmas nominais, categorias sintáticas do tipo XP. Neste ponto, os contrastes apresentados por Kayne (1975), Rizzi (1986) contribuíram para a motivação da proposta de Cardinaletti e Starke (1999). Os pronomes sujeitos do francês e dos dialetos do norte da Itália (DNI) possuem certas propriedades em comum, como a impossibilidade de serem modificados, receberem foco ou serem coordenados; são portanto, pronomes fracos. 


\subsubsection{As propostas voltadas ao estatuto fonológico}

O comportamento híbrido dos elementos clíticos, descrito por Zwicky (1977, p. 7) como ‘clíticos simples' e 'clíticos especiais', como já mencionado anteriormente, coloca de um lado 'palavras clíticas ordinárias' (conjunção, preposição, artigo, pronome etc.), e, de outro, pronomes clíticos com necessidade de 'sintaxe especial'. É com base nesse comportamento híbrido como itens fonologicamente dependentes mas bastante 'exigentes' em termos sintáticos que Galves \& Abaurre (2002 [1992]) (G\&A, daqui em diante) buscam uma análise dos ClsPrns do PB a partir da interface sintaxe-fonologia.

No nível prosódico, os clíticos pronominais são tratados como palavras funcionais, um conjunto finito de itens lexicais que apresenta propriedades prosódicas que os distinguem das palavras de conteúdo. Mas é possível considerá-los como parte integrante da palavra ou como elementos morfologicamente autônomos? O clítico sintático é sempre clítico fonológico, no sentido de que ele corresponde a um item lexical, sem acento primário, que se apoia, necessariamente, em outra palavra, mas como explicam as autoras (G\&A, 2002, p. 288), o inverso nem sempre é verdadeiro, pois nem todo clítico fonológico é um clítico sintático. ${ }^{105}$ Para tal, uma primeira questão enfrentada por G\&A foi delimitar o conceito de palavra face ao limite de fronteira de palavra - uma tarefa complexa, dadas as perspectivas teóricas sobre os mecanismos de atribuição do acento. Na literatura que trata deste tema, um dos pontos mais debatidos é em que medida o acento no PB é marcado na representação subjacente, ou seja, no léxico; ou ele pode ser previsível através de uma série de princípios, ou mesmo, se ambos os mecanismos compartilham a dinâmica acentual do PB. G\&A baseiam-se nas propostas metodológicas de análise métrica de Bisol (1992) e Collischonn (1993) sob os pressupostos da fonologia não-linear, para o acento primário e secundário do PB. ${ }^{106}$

Nos quadros abaixo, apresento, resumidamente, as propostas de grades métricas (simplificadas) de G\&A para a localização do acento primário, bem como das consequências

\footnotetext{
105 As autoras citam como exemplo a análise de Rizzi (1987) para o pronome sujeito je do francês que não é considerado por Rizzi um clítico sintático, apenas fonológico. Por trás dessa assunção está a noção sintática que distingue sintagmas XPs de $\mathrm{X}^{0} \mathrm{~s}$. Enquanto pronomes tônicos são analisados como sintagmas, clíticos são núcleos e sofrem restrições sintáticas impostas pelas gramáticas que impedem que eles possam ocupar posições argumentais finais derivadas, ou seja, clíticos pronominais têm de pousar em Flex, nas situações 'normais', ao menos, no domínio românico. Em sua posição derivada je ocupa uma posição argumental - sintagma nominal sujeito da oração - local de pouso impróprio para um clítico sintático.

${ }^{106}$ Dada a complexidade do assunto, apenas faço referência aos estudos de G\&A sem, no entanto, oferecer explicações relativamente às noções teóricas e metodológicas de árvore e grade métrica sob os pressupostos da fonologia não-linear. Sobre o assunto remeto o leitor aos trabalhos de Selkirk (1980, 1984), Liberman (1975, 1977), Kyparsky (1983), (Bisol, 1992), Collischonn (1993).
} 
para o ritmo (os apagamentos de colisão) em função das escolhas dos padrões de colocação proclítica ou enclítica. ${ }^{107}$

Como se pode verificar, no primeiro quadro (Quadro 7), a grade métrica no enunciado [Aquilo me chocou tanto] foi construída com base nas saliências fônicas de sua árvore prosódica. Veem-se marcadas, na linha 0 , todas as rimas ou sílabas (8); na linha 1 os acentos primários das palavras lexicais (3) e na linha 2 o acento de sintagma [tan] que marca a proeminência da sentença.

\section{Quadro 7 - Padrões rítmicos dos enunciados ${ }^{108}$}

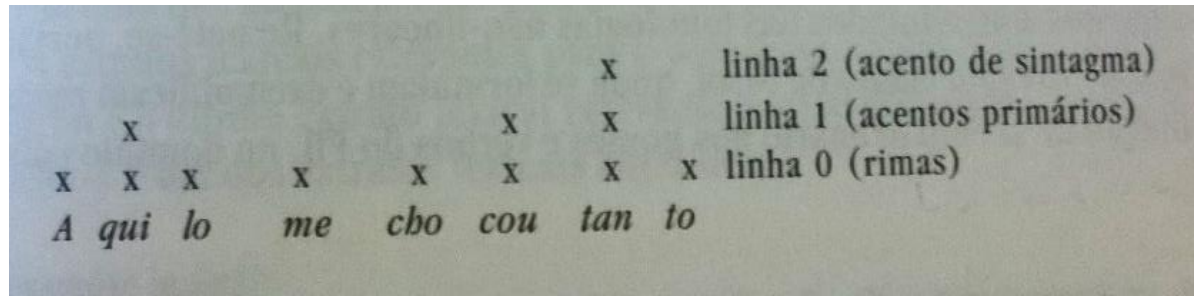

As informações fornecidas nas linhas 0 e 1 também serão levadas em conta na atribuição do acento secundário pelas autoras. Em PB, o acento secundário segue um padrão binário (Collischonn, 1993), ou seja, é marcado duplamente, diferentemente do acento primário.

Quanto à análise de enunciados com colocação proclítica de me, no Quadro 8, em [me chocou tremendamente]; nessa posição de colocação clítica, default no PB, o clítico está sendo considerado palavra autônoma, ${ }^{109}$ (não é parte integrante da palavra seguinte) como se vê na marcação de rima na linha 0 , seguida da marcação de acento primário na linha 1 .

\section{Quadro 8 - Colocação pronominal proclítica ${ }^{110}$}

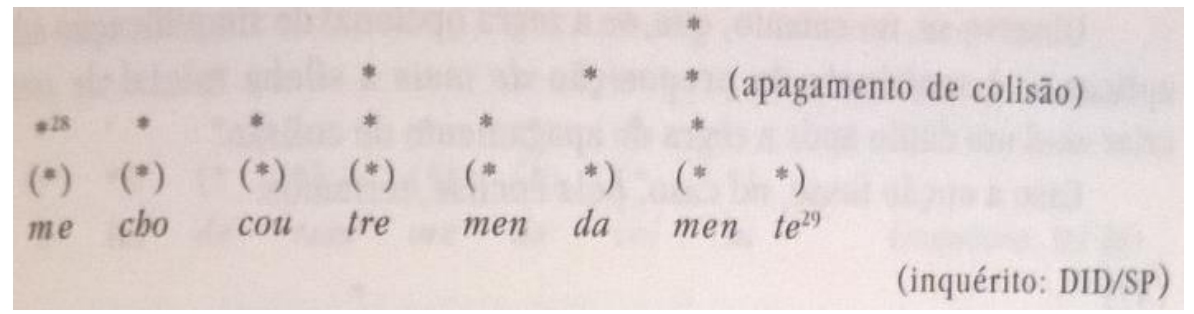

\footnotetext{
${ }^{107}$ Os quadros foram retirados de Galves \& Abaurre (2002, ps. 271 e 297).

${ }^{108}$ Retirado de Galves \& Abaurre, (2002, p. 271).

${ }^{109}$ Uma consequência dessa análise é que as autoras estão considerando os clíticos pronominais proclíticos ao verbo como DPs.

${ }^{110}$ Retirado de Galves \& Abaurre (2002, p. 297).
} 
Por último, na possibilidade de variação em ênclise do mesmo enunciado, a grade métrica demonstra que em construções enclíticas como [chocou-me tremendamente] o clítico é parte integrante do verbo, como se vê na marcação de rima na linha 0 , mais os apagamentos de colisão que ocorrem nas linhas 1 e 2 do quadro 9:

\section{Quadro 9 - colocação pronominal enclítica ${ }^{111}$}

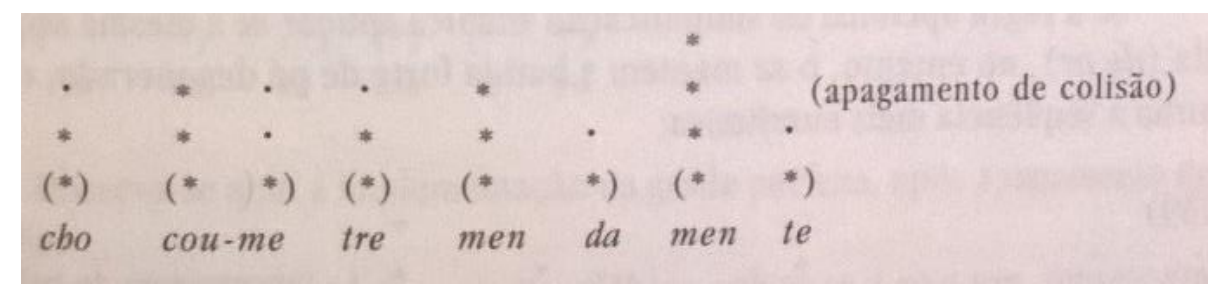

G\&A consideram as consequências rítmicas do nível do enunciado da opção sintática que a língua parece fazer pela próclise dos clíticos ao verbo, opção que corresponde à interpretação desses elementos como sintagmas (projeções máximas). Nesse caso, as autoras interpretam os clíticos do PB como clíticos fortes, consequentemente estão em adjunção à oração (em Flex'), mais imediatamente ao verbo e não exatamente ao núcleo, Flex. São algumas conclusões das autoras:

(i) os clíticos são sintagmas (projeções máximas) do ponto de vista sintático e palavras autônomas do ponto de vista fonológico;

(ii) os ClsPron do PB são palavras autônomas (DPs) quando proclíticas ao verbo, movendo-se como sintagmas em todos os níveis da gramática;

(iii) a próclise dos ClsPron é realizada como default no PB;

(iv) quando enclíticos (casos marcados na língua), os ClsPron são considerados como integrantes da palavra;

(v) do ponto de vista da fonologia, os ClsPron não são portadores de acento primário por serem todos monossilábicos e muitas vezes sujeitos a processos de redução fonológica em termos de realização fonética dos enunciados (sobretudo quando antecedem imediatamente uma sílaba ou outra palavra portadora de acento primário);

\footnotetext{
${ }^{111}$ Retirado de Galves \& Abaurre (2002, p. 297).
} 
(vi) os ClsProns do PB comportam-se como pronomes deslocados (não são clíticos sintáticos no sentido de ocuparem posição de núcleo e moverem-se em adjunção a outro núcleo, o Infl (nos termos de Kayne, 1991). Nesse sentido, as autoras defendem que o PB perdeu inteiramente os 'clíticos sintáticos', considerando-os clíticos 'fortes' que comportam-se como pronomes tônicos;

(vii) o desaparecimento dos clíticos núcleos é explicado pelo enfraquecimento da concordância, uma vez que a propriedade de flexão do PB é fraca tanto morfologicamente (com a redução do paradigma verbal) quanto interpretativamente (com a possibilidade de interpretação indeterminada do sujeito nulo das frases com tempo);

(viii) propõem uma posição em adjunção à categoria intermediária do núcleo flexional - Flex' (Flex-barra) para orações com período simples; para as orações com locuções, propõem uma posição de adjunção do ClPron à primeira projeção funcional contendo o verbo que é o AspP. Em sentenças negativas, os ClsProns permanecem adjungidos na mesma posição e não são afetados por elementos ligados a Infl, ${ }^{112}$

(ix) relativamente aos clíticos de terceira pessoa $o / a$, G\&A consideram que são os que tendem a desaparecer no PB e reiteram serem eles os menos tônicos entre os clíticos. Ideia de que são núcleos e se movem como núcleos. ${ }^{113}$

Quanto à afirmação de que, no PB, os ClcsPron são similares aos pronomes tônicos, as autoras levantam um problema que pode surgir dessa assunção, pois as duas classes têm comportamentos de colocação muito diferentes; por exemplo: "o que impede outros pronomes, como ele ou você, de se deslocarem na oração (cf. *eu ele vi), adjungindo-se à projeção da flexão?” (op. cit. p. 292). Segundo G\&A, esta impossibilidade deriva de uma outra restrição imposta pela gramática: a necessidade de visibilidade da função do pronome quando deslocado da sua função inicial: Os pronomes deslocados só podem ser aqueles que têm marca morfológica de caso (G\&A,op.cit., p. 292).

\footnotetext{
${ }^{112}$ Nos dados do PB, NegP não funciona como operador de próclise. Sobre a projeção de próclise e ênclise no PB proposta por Galves \& Abaurre (2002) ver a seção 2.4.4.5.

${ }^{113}$ Uriagereka (1992) analisou os clíticos de primeira e segunda pessoas como 'clíticos fortes' e os de terceira como 'clíticos fracos' ou determinantes, atribuindo-lhes o traço funcional dessa categoria, aproximando, assim, os clíticos acusativos ola do artigo definido. Por trás dessa análise está a assunção de que tais clíticos não são categorias lexicais ou XPs, mas funcionais como os afixos; e sendo eles núcleos $\left(\mathrm{X}^{0} \mathrm{~s}\right)$, movem-se como núcleos.
} 
Sobre o fator 'visibilidade' a que se referem G\&A, mais uma vez, retomo as contruções típicas de Jurussaca, cuja colocação do complemento acusativo não é transparente:

(33) Ele nós ajudou.

uma vez que, ainda que o pronome nessa construção tenha alguma proeminência fonológica, mas, por conta da 'necessidade de visibilidade', é de se supor que o pronome em questão tenha alguma marca morfológica de Caso. Logo, ele deve se diferenciar do pronome lexical 'idêntico', licenciado na posição de sujeito. Seria ele, então, um ClPron? Retomo a essa questão no terceiro capítulo.

Sobre a redução do quadro pronominal clítico no PB, G\&A apresentam o quadro abaixo relativamente ao PB culto, conforme ocorrências do projeto NURC: ${ }^{114}$

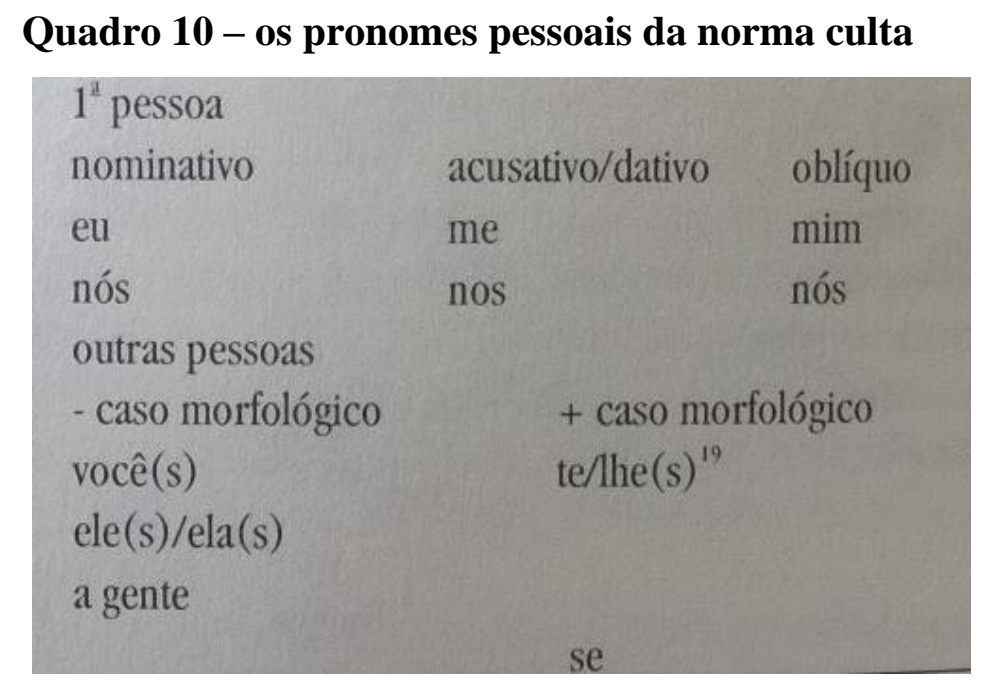

Nas ocorrências apresentadas no quadro acima, somente a primeira pessoa dispõe do paradigma completo de morfologia de caso e as demais ocorrem como [-Caso morf.] você, ele(s) ela(s), a gente, e [+Caso morf.] te, lhe (s). Este quadro, no entanto, contrasta com as ocorrências pronominais de Jurussaca, que registra o paradigma de segunda pessoa (singular), também, completo: $[t u, t e, t i]$ e em variação relativamente aos itens presentes no quadro para a segunda pessoa. No capítulo 3, retorno a esse quadro.

Na próxima seção, volto-me ao estudo dos clíticos nas variedades de PE e PB.

114 Quadro retirado de Galves \& Abaurre (2002, p. 292). 


\subsubsection{As construções com pronominais clíticos em português}

No que se refere ao domínio da língua portuguesa, a colocação de pronomes clíticos nas variedades de português brasileira e europeia é um dos tópicos mais interessantes da sintaxe dessas duas línguas. Galves (2001a, p. 126) chamou a atenção para as diferenças entre o alto uso de clíticos de $1^{\mathrm{a}}$. e $2^{\mathrm{a}}$. pessoas e o baixíssimo uso de clítico de $3^{\mathrm{a}}$. no $\mathrm{PB}$. Na verdade, a tese da autora defende a inexistência de clítico de terceira pessoa na gramática do $\mathrm{PB}$, tese confirmada pela ausência deles na fala das crianças e, portanto, fora da aquisição.

No português europeu, nas orações finitas assim como infinitivas encaixadas, a colocação dos clíticos é não-marcada e o padrão é a ênclise; ${ }^{115}$ (cf. Duarte \& Matos, 2000): ${ }^{116}$

(34) a. Ele viu- $a$

b O João pensa vê-la mais tarde

Já nos casos em que ocorre próclise em PE, ela será licenciada por um operador (negação, elementos $w h$, NPs quantificados, elementos focalizados, etc.) que irá $c$-comandar o hospedeiro do clítico (cf. Duarte \& Matos, 2000, p. 117). Esses casos não ocorrem em contextos de variação (como no PB). Nas orações principais, a próclise está associada, em $\mathrm{PE}$, à negação. No entanto, em orações afirmativas também ocorre próclise e, nesse caso, ela está associada aos processos gramaticais de quantificação, de focalização e de ênfase e é licenciada por um operador, como já mencionado (cf. Duarte \& Matos, 2000; Martins, 2013): ${ }^{117}$

(35) a. O João não $o$ comprou

b. Eles disseram que os amigos thes deram os livros

c. Que mentira lhe contaste?

d. Todos os alunos se riram

e. Até a ele lhe contaram mentiras

f. O João já o comprou

\footnotetext{
115 Em português europeu, as orações principais que apresentam ênclise são sempre afirmativas e podem, também, ser declarativas, imperativas, exclamativas ou interrogativas totais (MARTINS, 2013, p. 2239).

${ }^{116}$ Exemplos retirados de Duarte \& Matos (2000, p. 117, renumerados).

${ }^{117}$ Exemplos retirados de Duarte \& Matos (2000, p. 118-119, e renumerados)
} 
g. Ele também $o$ leu

Assim, como já mencionado, os contextos de ocorrência de próclise em PE estão relacionados à negação (sentenças negativas) e aos contextos gramaticais que englobam as relações de ênfase, focalização e de quantificação.

O quadro abaixo, adaptado de Martins (2013), exemplifica tais contextos:

\section{Quadro 11 - Orações principais com próclise}

\begin{tabular}{|c|c|}
\hline Contextos de proclização & Exemplos dos casos estudados \\
\hline Negação & $\begin{array}{l}\text { Os cães não a assustam. } \\
\text { Nada a assusta. }\end{array}$ \\
\hline Quantificadores & $\begin{array}{l}\text { Poucos cães a assustam. } \\
\text { Muitos cães a assustam. (vs. Muitos } \\
\text { cães assustam-na.) }\end{array}$ \\
\hline Advérbios focalizadores & $\begin{array}{l}\text { Só aquele cão te morderia. } \\
\text { Até o gato me mordeu }\end{array}$ \\
\hline Advérbios enfatizadores & $\begin{array}{l}\text { Bem te disse que não o soltasses. } \\
\text { Lá me está ele a rosnar. }\end{array}$ \\
\hline Advérbios focalizados & $\begin{array}{l}\text { Sempre o vejo zangado. } \\
\text { Ali se construiu o mosteiro (vs. Ali, constrói- } \\
\text { se de forma selvagem.) } \\
\text { Rapidamente se afastou (vs. } \\
\text { Rapidamente, afastou-se.) }\end{array}$ \\
\hline $\begin{array}{l}\text { Outros focos contrastivos antepostos } \\
\text { (não adverbiais) }\end{array}$ & $\begin{array}{l}\text { Nas pernas se fiava ele. } \\
\text { Um golpe traiçoeiro a derrubou. }\end{array}$ \\
\hline Declarativas enfáticas & $\begin{array}{l}\text { Um dia se saberá toda a verdade. } \\
\text { Pois te garanto que é assim. }\end{array}$ \\
\hline Interrogativas e exclamativas qu- & $\begin{array}{l}\text { Quem te contou? } \\
\text { Como ele me irrita! }\end{array}$ \\
\hline Imperativas com que; optativas & $\begin{array}{l}\text { Que me tragam o apito depressa. } \\
\text { Bons olhos te vejam. }\end{array}$ \\
\hline Interrogativas retóricas com acaso & Acaso te julgas a salvo? \\
\hline $\begin{array}{l}\text { Próclise e ênclise com a palavra } \\
\text { próprio }\end{array}$ & $\begin{array}{l}\text { Eu próprio lhe dei a notícia. } \\
\text { Eu próprio dei-lhe a notícia. }\end{array}$ \\
\hline
\end{tabular}

Quadro 11 - Orações Principais com Próclise (adaptado de Martins (2013, p. 2242)

Nos contextos acima, como se pode ver, há alguns casos de variação entre a próclise e a ênclise (com os advérbios focalizadores ali e rapidamente e com a palavra próprio), mas, ainda que haja a dupla possibilidade de colocação do clítico, em alguns exemplos, nos 
contextos em que ocorrem a próclise, as estruturas são derivadas e os núcleos que hospedam o clítico ocorrem em contextos sintáticos pragmaticamente diferenciados.

Em se tratando de contextos de quantificação, ocorre bastante variação em PE e é necessário relativizar certos contextos. A título de exemplo, menciono alguns dos casos tratados por Martins (2013):

(i) A próclise é o padrão regular com quantificadores do tipo de poucos (algo, alguém, algum, ambos, bastante, demasiado/demasiados, mais, menos, muito, pouco/poucos, raramente, suficientes, tal/tais), no entanto, com os quantificadores algo, alguém, algum, todos é possível identificar situações particulares que escapam ao padrão regular proclítico; estes quantificadores não desencadeiam próclise quando as expressões nominais em que ocorrem são modificadas por orações relativas restritivas com o verbo no subjuntivo. Nesta situação, como mostram os exemplos (36) a (39), a colocação dos pronomes clíticos é enclítica e não proclítica. ${ }^{118}$

(36) a. Algo que possa correr mal deixá-lo-á inconsolável.

b. *Algo que possa correr mal o deixará inconsolável.

(37) a. Alguém que \{chegue/tenha chegado\} tarde perde-se, com certeza, no meio dessa argumentação.

b. *Alguém que $\{$ chegue/tenha chegado $\}$ tarde se perde, com certeza, no meio dessa argumentação.

(38) a. Alguma pessoa que \{chegue/tenha chegado $\}$ tarde perde-se, com certeza, no meio dessa argumentação.

b. *Alguma pessoa que $\{$ chegue/tenha chegado $\}$ tarde se perde, com certeza, no meio dessa argumentação.

(39) a. Todas as pessoas que $\{$ cheguem/tenham chegado $\}$ tarde perdem-se, com certeza, no meio dessa argumentação.

b. *Todas as pessoas que $\{$ cheguem/tenham chegado $\}$ tarde se perdem, com certeza, no meio dessa argumentação.

118 Todos os exemplos foram retirados de Martins (2013, p. 2247, e renumerados). 
(ii) Há casos, porém, em que a leitura distributiva e não grupal do quantificador restringe a possibilidade de ocorrência de ênclise: ${ }^{119}$

(40) a. *Todas as bailarinas descalçaram-se

b. Todas as bailarinas se descalçaram

Martins (op. cit.) explica que, nos casos como (40), o uso da próclise é obrigatório uma vez que o predicado descalçaram-se designa um conjunto de eventos e em cada um deles tem como participante uma bailarina pertencente ao conjunto designado pela expressão todas as bailarinas. Em (40) todas as bailarinas tem necessariamente uma interpretação distributiva, e não grupal.

(iii) Inversamente ao exemplo (40), quando as expressões nominais quantificadas por todos designam um grupo de indivíduos que participam conjuntamente num dado evento, e não há leitura distributiva é possível a ênclise: ${ }^{120}$

(41) a. Todos os chineses que vivem em Lisboa reúnem-se uma vez por ano no Parque das Nações

b. Toda a população chinesa que vive em Lisboa reúne-se uma vez por ano no Parque das Nações

c. Todas as girafas, ao pressentirem o incêndio, deslocaram-se em direcção ao lago

Nos exemplos (41), Martins (op. cit.) explica a possibilidade de colocação enclítica dos pronomes uma vez que todos tem uma leitura de grupo, tornando-se por isso compatível com a modificação por orações relativas restritivas.

(iv) Os quantificadores todos e tudo deixam de associarem-se à colocação proclítica dos pronomes átonos quando ocorrem em posição pós-nominal, ainda que antecedam o verbo. Segundo Martins (2013), nesta situação, eles têm leitura de grupo: ${ }^{121}$

\footnotetext{
${ }^{119}$ Exemplos retirados de Martins (2103, p. 2248, e renumerados).

${ }^{120}$ Exemplos retirados de Martins (2013, p. 2248, renumerados).

${ }^{121}$ Exemplos retirados de Martins (2013, p. 2248, renumerados).
} 
(42) Os meus amigos todos vão-me oferecer aquele livro que eu tanto queria

(43) Isso tudo perdeu-se (Herculano, apud Said Ali 1908: 50)

(v) Os quantificadores muitos, bastantes, raros, quase, funcionando como pronomes ou como especificadores adjetivais, também apresentam variação. Martins (op. cit., p. 2248) chama a atenção para as distinções semânticas que ocorrem nos exemplos em (44) quanto à colocação das palavras quantificadas muitos/muitas: $:^{122}$

(44) a. Muitas pessoas vacinam-se todos os anos (= há muitas pessoas que todos os anos se vacinam).

b. Muitas pessoas se vacinam todos os anos. (= o número de pessoas vacinadas é todos os anos grande).

Tais distinções semânticas são muito significativas quando se compara PE e PB, pois em PB não me parece possível estabelecê-las apenas quanto ao uso próclise $v s$ ênclise. Para Martins (op. cit.), nas frases acima, com muitos/muitas, a variação entre colocação proclítica e colocação enclítica dos pronomes átonos associa-se, em geral, a distinções semânticas. Martins argumenta que tanto na frase (44 a), com ênclise, quanto na frase (44 b), com próclise, a palavra muitas define uma quantidade (elevada), no entanto, a diferença entre as duas frases consiste no fato de que em (44 a) muitas tem simultaneamente um valor referencial, apontando um conjunto particular de pessoas (que poderiam ser identificados); já na frase (44 b) muitas é puramente quantificacional, delimitando apenas um certo universo quantitativo.

Para a autora, o contraste semântico exemplificado por (44) torna-se mais nítido quando se substitui o predicado vacinar-se por um predicado como suicidar-se:

(45) a. *Muitas pessoas suicidam-se todos os anos (= há muitas pessoas que todos os anos se suicidam).

b. Muitas pessoas se suicidam todos os anos. (= o número de pessoas que comete suicídio é grande todos os anos).

${ }^{122}$ Exemplos retirados de Martins (2013, p. 2249, renumerados). 
A frase (45a) com ênclise, e interpretação referencial de muitas pessoas, exprime uma asserção necessariamente falsa, dada a impossibilidade de a mesma pessoa cometer suicídio repetidamente, enquanto a frase (45b), com próclise e interpretação puramente quantificacional de muitas pessoas e não (co)referencial, pode exprimir uma asserção verdadeira.

Aos exemplos de (45), também me parece haver em PB a mesma restrição semântica observada por Martins (op. cit.) face à inaceitabilidade de (45a) em que o pronome 'se' tem interpretação (co)referencial.

\subsubsection{A subida de clítico}

Além do padrão de colocação proclítico e enclítico no português, discutido na subseção anterior, uma outra construção bastante usual no PE (e também no italiano, no francês e no espanhol) é a subida de clítico. Essa construção, no entanto é completamente ausente no PB, salvo em orações formadas pelo complexo auxiliar+gerúndio, como: Não o estava vendo. ${ }^{123}$ No entanto, não se trata de uma construção de subida de clítico canônica.

É atribuído a Kayne (1975) o trabalho inaugural sobre esse tema. Kayne, analisando estruturas sintáticas do francês, chamou a atenção para a possibilidade de verbos pertencentes a domínios oracionais distintos poderem comportar-se como uma unidade estrutural, dando lugar a um outro processo de subida do pronome complemento clítico. Os clíticos gerados nas sentenças encaixadas, embora sejam argumentos do verbo encaixado, têm de ser colocados em posição proclítica ao verbo mais alto. Tais construções passaram a ser conhecidas como construções fair+infinitiv (fazer+infinitivo): ${ }^{124}$

(46) a. Elle fera manger ce gâteau à Jean. (Kayne, 1975, p. 255)

Ela fará comer o bolo ao João

(Ela fará o João comer o bolo)

Nessas construções, os NPs complementos do verbo encaixado, quando substituídos por clíticos, não podem ficar hospedados junto ao verbo encaixado (que lhes atribui papel temático); têm de subir até a posição à esquerda do verbo mais alto. No exemplo de Kayne, acima, o clítico adjunge-se à esquerda de faire, dando lugar à operação de subida de clítico:

\footnotetext{
${ }^{123}$ Notas 80, 81, 82, seção 2.4.2.

${ }^{124}$ Exemplos retirados de (Kayne, 1975, p. 255 e renumerados).
} 
(47) a. Elle le fera manger à Jean.

b. Elle lui fera manger ce gâteau.

Uma vez bloqueada, a posição mais baixa não pode hospedar clíticos em francês. É, portanto, agramatical a ocorrência de clíticos nessa posição, conforme se pode verificar nos exemplos agramaticais, abaixo: ${ }^{125}$

(48) a. *Elle fera le manger à Jean

b. *Elle fera lui manger ce gâteau

Segundo Cyrino (2010, p. 190), a construção de subida de clítico ocorre em três estruturas nas línguas românicas: Faire+Infinitive; auxiliar+particípio (ou tempo perifrástico) e construção de reestruturação (em que a locução verbal forma um único domínio temporal), sendo obrigatória apenas nas duas primeiras. Essas três estruturas englobam as construções conhecidas como 'predicado complexo sintático'. ${ }^{126}$ Algo mais que se pode dizer sobre essas construções de predicado complexo é que, normalmente, são formadas por verbos de controle ou de alçamento. Para Cyrino (2010, p. 189), a ausência de subida de clítico em PB, conforme (49), é um dos efeitos da ausência da construção de predicado complexo sintático: ${ }^{127}$

(49) *Me quis telefonar ontem.

Sintaticamente, em tais construções (cf. Cyrino, op. cit. p. 188), ocorre o movimento do complemento do verbo não finito para o especificador de $\mathrm{V}$ finito (mais alto). Esse movimento forma um predicado complexo, propiciando a subida do clítico. As orações do português europeu, abaixo, são exemplos dessas construções, com subida de clítico obrigatória em (50b) e (51a) e opcional em (52): ${ }^{128}$

(50) a. O João mandou comer a sopa à Maria. (faire+Infinitiv)

b. O João $a$ mandou comer à Maria.

\footnotetext{
${ }^{125}$ Exemplos retirados (Kayne, 1975, p 256 e renumerados).

126 As construções de predicado complexo são aquelas em que um verbo que seleciona um complemento infinitivo constitui um núcleo sintaticamente complexo com o verbo deste complemento (Rizzi, 1982; Burzio, 1986, apud Gonçalves, 1999).

${ }^{127}$ Exemplo retirado de Cyrino (2010a p. 189) e renumerado.

${ }^{128}$ Exemplos retirados de Cyrino (2010b, p. 190, 191) e renumerados.
} 
(51) a. O João não me tinha visto.

(auxiliar+particípio)

b. *O João não tinha visto-me.

c. *O João me não tinha visto

(52) a. O João me quis visitar.

(construção de reestruturação)

b. O João quis-me visitar

c. O João quis visitar-me

Gonçalves (1999) cita os trabalhos baseados no italiano, feitos por Rizzi (1978, 1982) nos quais considera a existência de uma outra classe de verbos, que inclui os modais, os aspectuais e alguns verbos de movimento, cujos membros parecem também formar uma unidade estrutural com o verbo do seu complemento infinitivo. Tal como acontece com os verbos causativos do francês, com os verbos do italiano incluídos na classe mencionada é possível a cliticização de complementos do verbo encaixado no verbo principal:

(53) Piero $t i$ verrà a parlare di parapsicologia. (Rizzi 1982: 1;)

Diferentemente do francês, cuja subida do clítico é obrigatória, nessas construções do italiano, como explica Gonçalves (1999), construções que envolvem os modais, os aspectuais e alguns verbos de movimento, a subida de clítico é opcional, sendo possível o exemplo (54) em que o clítico se mantém adjacente ao verbo de que é complemento:

(54) Piero verrà a parlarti di parapsicologia. (idem.)

Gonçalves (op. cit.) afirma que o PE dispõe tanto da construção referente ao francês (com subida de clítico obrigatória), quanto das construções do italiano (com subida de clítico não obrigatória). Nessas construções os dois verbos parecem formar uma unidade do ponto de vista sintático. São exemplos de Gonçalves (1999):

O PE, tal como a generalidade das línguas românicas, dispõe dos dois tipos de construções acima apresentadas, nas quais os dois verbos parecem formar uma unidade do ponto de vista sintáctico. Assim,

(i) nas construções com verbos causativos ou perceptivos, os dois verbos podem ocorrer adjacentes, realizando-se o Sujeito encaixado como Objecto Directo (OD) ou como Objecto Indirecto (OI), como veremos na secção 3.4, alínea C. São exemplos deste tipo de construção as frases (6b) e (7b):

(6) a. O João mandou a Ana entrar.

b. O João mandou entrar a Ana.

(7) a. O João mandou a Ana procurar o livro. 
b. O João mandou procurar o livro à Ana.

(ii) nas construções com os verbos de Reestruturação de Rizzi (1982), os dois verbos ocorrem sempre adjacentes, sendo, no entanto, possível detectar a existência de uma sequência verbal coesa através da possibilidade de Subida de Clítico. O exemplo relevante é apresentado em (8c):

(8) a. O João não quer conhecer a Marta.

b. O João não quer conhecê-la.

c. O João não a quer conhecer.

(GONÇALVES, 1999, p. 36-37)

Sobre a subida de clítico ainda é importante frisar que, no PE, em construções com gerúndios e particípios, o processo é obrigatório (cf. Martins, 2013, p. 2234):

As configurações de subida do clítico são obrigatórias, e já não opcionais, nos complexos verbais com gerúndio e com particípio passado (ia-lhes oferecendo alpista até ganharem confiança e tinha-lhes dado alpista durante um mês quando se atreveram a aproximar-se) - vs. ??ia oferecendo-lhes alpista até ganharem confiança ou *tinha dado-lhes alpista durante um mês quando se atreveram a aproximar-se, apesar de nestas frases os pronomes clíticos serem complemento, respectivamente, de oferecer e de dar. Na ausência de um verbo finito, os pronomes clíticos associam-se ao gerúndio nas orações gerundivas (tendo conquistado o melro, passou aos pardais vs. tendo-o conquistado, passou aos pardais), mas não ocorrem nas orações participiais (conquistado o melro, passou aos pardais vs. *conquistado-o, passou aos pardais).

(MARTINS, 2013 p. 2234) - grifos meus).

Há também algumas restrições quanto à subida de clítico em construções de predicado complexo. Os exemplos abaixo, do PE, com a possibilidade de subida de clítico em (55 b) e a restrição ao mesmo movimento em (56 b) são bastante significativos: ${ }^{129}$

(55) a. Todos os jornalistas quiseram entrevistar esse candidato

b. Todos os jornalistas $o$ quiseram entrevistar

(56) a. Todos os jornalistas prometeram entrevistar esse candidato

b. *Todos os jornalistas $o$ prometeram entrevistar

A restrição que ocorre em (56 b) é interessante, primeiramente, porque mostra que o movimento ocorre não em razão da presença do quantificador 'todos' mas sim, pela construção de predicado complexo em (55), cujo predicado ainda que seja composto por dois domínios frásicos diferentes, comporta-se como uma unidade, formada pelo verbo matriz

${ }^{129}$ Exemplos retirados de Gonçalves (2013 p. 3, renumerados). 
com o verbo do complemento infinitivo. Para Gonçalves (2013, p. 3), o infinitivo tem traços de temporalidade, podendo a localização da oração encaixada estar dependente ou não do tempo da matriz na projeção do núcleo $\mathrm{T}$ (os dois podem ser localizados em intervalos de tempo coincidentes ou não - anterior, concomitante e posterior), atestando que, quando se trata de reestruturação, há uma condição semântica a ser considerada: as relações temporais entre a matriz e o domínio infinitivo.

Assim, para Gonçalves (op. cit.), prometer e querer ao mesmo tempo que impõem uma leitura de posterioridade da situação encaixada: a situação da oração com o infinitivo simples só pode ser localizada num intervalo de tempo posterior ao da respectiva matriz, sendo as relações de sobreposição e de anterioridade excluídas; eles também têm comportamentos distintos relativamente à reestruturação uma vez que as orações subordinadas a estes verbos manifestam comportamentos distintos no que diz respeito aos mecanismos de dependência temporal. Nas orações abaixo, o modificador temporal 'amanhã' tem valor distinto do valor temporal dos domínios frásicos, afetando-os. ${ }^{130}$

(57) *Os jornalistas quiseram entrevistar esse candidato amanhã

(58) Os jornalistas prometeram entrevistar esse candidato amanhã

Mas prometer não é sensível à alteração do modificador temporal, o que parece ser um argumento a favor de que haja dois domínios temporais em jogo, atestando que em (58) não ocorra uma construção de estrutura de reestruturação, já que apesar de ambos influenciarem de forma semelhante a localização da situação encaixada, as orações subordinadas a estes verbos (querer, prometer) manifestam comportamentos distintos no que diz respeito aos mecanismos de dependência temporal.

\subsubsection{A interpolação clítica}

As construções de interpolação clítica foram largamente utilizadas em fases anteriores da língua portuguesa, como comprovam os estudos diacrônicos. A interpolação consiste na quebra da adjacência entre o clítico e o seu hospedeiro - o verbo - pelo marcador

${ }^{130}$ Exemplos retirados de Gonçalves (2013 p. 3, renumerados). 
de negação frásica (não) que pode, opcionalmente, interromper a continuidade entre um clítico pré-verbal e o verbo: ${ }^{131}$

(59) a. O que ele lhe não terá dito! (interpolação de não)

b. O que ele não lhe terá dito!

Mas no PE contemporâneo, segundo Martins (2013, p. 2233), as construções de interpolação (de um constituinte entre o clítico e o verbo) têm um âmbito muito restrito. Elas são mais utilizadas nas variedades dialetais contemporâneas do português. Nessas variedades, segundo a autora, admitem-se a interpolação de pronomes e advérbios de natureza dêitica: ${ }^{132}$

(60) a. isso já me ele tinha dito

b. nunca nos cá vens ver

A autora reforça ainda que nenhum dialeto de português conservou a interpolação generalizada do português antigo, visível numa frase como: se nos Deus entõ a morte nõ deu, comumente utilizada em textos como as Cantigas de Amor dos Trovadores GalegoPortugueses.

\subsubsection{Grupos clíticos}

Uma outra construção presente no PE e ausente no PB, está relacionada à formação de grupos clíticos ou locuções clíticas. Trata-se do 'agrupamento' de mais de um pronome pessoal em uma mesma oração, como se pode verificar nos exemplos a seguir, do PE: ${ }^{133}$

(61) a. vou devolver o livro ao António

b. vou devolver-lho

Em PE, numa frase como em (61a), os complementos acusativo [o livro] e dativo [ao Antônio] ao serem comutados pelos pronomes correspondentes, os mesmos ficam agrupados, formando o complexo lho (cf. 61b). Segundo Martins (2013), essa coesão dos

\footnotetext{
${ }^{131}$ Exemplos retirados de Martins (2013, p. 2233, renumerados).

132 Exemplos retirados de Martins (2013, p. 2233, renumerados).

${ }^{133}$ Exemplos retirados de Martins (2013, p. 2234, renumerados).
} 
grupos clíticos pode ser encontrada nos domínios infinitivos que admitem variação entre próclise e ênclise.

Ainda segundo Martins (2013), em PE:

A separação entre dois pronomes clíticos complemento de um mesmo verbo infinitivo, obtida colocando um deles em próclise e o outro em ênclise, não é permitida. Assim, tenho de lho devolver e tenho de devolverlho são ambas frases gramaticais, mas *tenho de lhe devolvê-lo ou *tenho de o devolver-lhe não são opções permitidas pela gramática do português, embora sejam possíveis tenho de lhe devolver o livro e tenho de devolvê-lo ao António.

Martins (2013, p. 2234)

A ordem dos grupos clíticos é fixa, segundo Martins (2013):

Dentro dos grupos clíticos, os pronomes pessoais apresentam uma ordem fixa. O pronome se precede sempre qualquer outro pronome clítico e, por sua vez, um pronome clítico dativo precede sempre um clítico acusativo. [...] um grupo clítico pode ser constituído por três elementos $(s e+$ dativo + acusativo), ou apenas por dois (seja dativo + acusativo, seja $s e+$ dativo. Não é, no entanto, permitida a formação de um grupo clítico constituído por *se + acusativo, como mostra a impossibilidade de frases como: *pintase-a de azul, *ouve-se-os gritar o tempo todo, *cura-se-te com banhos de mar, *penteia-se-te com tranças, *engana-se-vos facilmente.

Martins (2013, p. 2234)

A ordem se + clítico dativo + clítico acusativo, mencionada por Martins, no excerto acima, é ilustrada pelas frases que se seguem: ${ }^{134}$

(62) a. Histórias de lobisomens, ouvia-se-lhas vezes sem conta. [se + dat. + ac.]

b. Conta-mas. [dat. + ac.]

c. Os olhos encheram-se-lhe de lágrimas. [se + dat.]

d. A boca abriu-se-te de espanto. [se + dat.]

\subsubsection{Projeções estruturais de ênclise e próclise em PE}

Como já mencionado na seção (2.4.3.1), a colocação pronominal clítica das línguas românicas foi analisada por Kayne (1991) como estrutura derivada, propondo que os pronomes clíticos são gerados na posição NP/DP e, em seguida, cliticizados à categoria funcional I (Cl-I) por uma regra obrigatória de movimento. Nos casos de sentenças

${ }^{134}$ Exemplos retirados de (Martins (2013, p. 2234, renumerados). 
encaixadas não finitas, o italiano não permite a ordem $\mathrm{Cl}-\mathrm{V}$ e, nesse caso, o clítico está adjungido também a I, no entanto, o verbo move-se à esquerda, passando por I e ocupando uma posição mais alta, em adjunção a I' (I-barra).

Porém, no português europeu, em que o padrão de colocação clítica é a ênclise, sem, contudo, haver relação com o tempo finito (como ocorre no italiano e no francês), a aplicação da proposta de Kayne nos mesmos termos passa a ser problemática. Alguns autores propuseram diferentes análises para a derivação dos pronomes clíticos em próclise/ênclise para o PE: Madeira (1992); Rouveret (1992); Martins (1996); Raposo (2000); Duarte \& Matos (2000); Duarte, Matos \& Gonçalves (2002), entre outros. No estudo de Martins, a autora propôs, com base em Laka (1990), a Categoria Funcional Sigma - $\Sigma$ P -, acima de TP, para os fenômenos de próclise e, nos casos de ênclise, adjunção ao núcleo verbal em TP. Nas propostas mais recentes, no entanto, a categoria $\Sigma$ P tem sido posta de lado. $^{135}$

Nesta seção, apresento, resumidamente, as propostas de projeção de Duarte \& Matos (2000) (D\&M, daqui em diante) e Duarte, Matos \& Gonçalves (2005) (D,M\&G, daqui em diante) para ênclise e próclise em PE. As autoras, não seguem as propostas vigentes na literatura com base em um núcleo funcional adicional acima de TP (como $\Sigma$ P, por exemplo). D\&M (2000) postulam os núcleos funcionais concernentes à divisão de I propostos por Chomsky (1991, 1995): ${ }^{136}$ AgrSP e AgrOP, núcleos que satisfaziam as propriedades de movimento de elementos checados tanto antes quanto depois de Spell-out. D,M\&G (2005) revisitam a proposta de D\&M (2000) e propõem as categorias Asp e $T$ de acordo com o status argumental vs. não-argumental do clítico.

Uma das primeiras considerações a se fazer é quanto à explicação que D\&M propõem para o padrão enclítico do PE - consideram que nessa língua o clítico em ênclise tem estatuto fonológico 'quase-afixo' (affix-like).

Outro aspecto a ser mencionado é a assunção das autoras de que a cliticização nas línguas românicas envolve incorporação e checagem de traços antes de Spell-out, já que os

\footnotetext{
${ }^{135} \mathrm{Na}$ literatura há outras propostas de análise das colocações clíticas ênclise/próclise nas línguas românicas, com base em categorias funcionais altas, como WP, proposta Rouveret (1992); FP, por Uriagereka (1995) e CP, por Madeira (1992).

${ }^{136}$ Com base nos distintos padrões de concordância existentes entre as línguas que são evidenciados, por exemplo, pela existência de línguas que exibem concordância de objeto, o quadro teórico da GB, no final dos anos 80 (POLLOCK, 1989, inicialmente) propôs a divisão da projeção do núcleo flexional de $\mathrm{V}$ - InfP - em projeções funcionais em $T$ (tempo/aspecto) e $A g r$ (responsável pela concordância de sujeito), com $T$ ocupando posição mais alta que Agr. Mas, segundo Hornstein at all (2010, p. 118), foi Chomsky (1991) que propôs um refinamento da proposta estrutural anterior, assumindo duas projeções de $A G R$ : $A g r S$, para a concordância do sujeito e $\mathrm{AgrO}$ para os casos de concordância do objeto.
} 
clíticos têm traços- $\varphi$ fortes. ${ }^{137}$ Conforme já mencionei anteriormente, em P\&P há propostas teóricas diferentes relativamente ao tratamento dos clíticos: como afixos, nesse caso gerados diretamente no núcleo de uma categoria lexical (hipótese da afixação); ou como núcleo de DPs (cf. Kayne (1991)). Nesse caso, seriam gerados como argumentos do verbo e, em seguida, movidos para uma projeção funcional ( $\Sigma P, I P, \operatorname{AgrSP}, \operatorname{AgrOP}$, etc.), cujo alvo para a afixação, ao menos nas línguas românicas, será a categoria verbal. Para D\&M, clíticos não são afixos, mas DPs transitivos que subcategorizam um pro (NP) como complemento: ${ }^{138}$

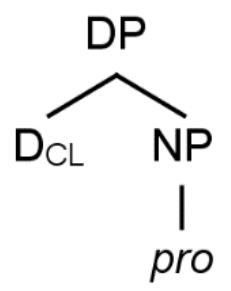

Ao tratar elementos clíticos como Ds transitivos, D\&M consideram as seguintes implicações: (i) as motivações para movimento de clíticos em Overt Syntax e (ii) as razões para que este movimento produza diferentes padrões de ordem entre as línguas românicas e também na mesma língua. As autoras sugerem que respostas envolvendo as implicações em (i)-(ii) possam estar nos traços formais intrínsecos dos clíticos; por exemplo, clíticos românicos têm como traços fortes, o traço V-host e a especificação por Caso, motivando a checagem desses traços diante do núcleo de $V$ (V-head), e forçando o movimento dos mesmos em sintaxe aberta (cf. Kayne, 175, Corver \& Delfitto, 1993, Uriagereka, 1995). No entanto a explicação de que o movimento dos clíticos ocorra para checagem de traços fortes, para as autoras, não consegue explicar uma outra característica dessas categorias: o seu comportamento especial quanto ao padrão de colocação em próclise e em ênclise (op cit. p. 122). Assim, surgiram diferentes análises para os diferentes padrões de colocação clítica, com as projeções funcionais altas como $W P, \Sigma P, F P$ e $C P$, propostas respectivamente por Rouveret (1992); Laka (1990), Uriagereka (1995) e Madeira (1992).

Primeiramente, D,M\&G corroboram a abordagem teórica sintática do Programa Minimalista (Chomsky, 1995, e versões mais recentes) no sentido de que tanto ênclise quanto próclise resultam das operações de Merge e Agree desencadeadas pelos requisitos de match e deletion (correspondência e apagamento), empregados aos traços formais não

\footnotetext{
${ }^{137}$ Sobre a assunção de que pronomes clíticos tenham traços fortes e/ou fracos, ver nota 80.

${ }^{138}$ Esquema de projeção retirado de D\&M (2000, p 129). As autoras seguem a hipótese proposta por Cover \& Delfitto (1993).
} 
valorados durante a derivação; e acrescentam que tais operações são distintas das operações fonológicas de cliticização, as quais, como é sabido, aplicam-se a outras formas linguísticas para além do clíticos pronominais. $D, M \& G$ (2005, p. 121) assumem os seguintes pressupostos teóricos:

(i) o 'local' de cliticização é fixo e uniforme entre as construções e as línguas (crosslinguistic), seguindo (Sportiche, 1998 e Schlonsky, 2004) e argumentam que o nódulo clítico (ClP) é selecionado por AspP;

(ii) a operação Agree valora as sondas dos traços- $\varphi$ dos clíticos no domínio $v \mathrm{P}$ sob c-comando local;

(iii) ênclise é a opção default para colocação de clíticos e próclise é opção de último recurso.

Conforme se poderá verificar nos quadros 12 e 13 abaixo, ao contrário das propostas que preveem núcleos funcionais acima de TP, bem como da proposta de Kayne (1991), que previa movimento de núcleo $C l$ - $V$ e tomava a próclise como default nas línguas românicas, $D, M \& G$ assumem que a derivação sintática básica dá lugar à ênclise, obtida crosslinguisticaly a partir do movimento do clítico para uma posição funcional $(C l P) \mathrm{e}$ ‘adjunção à esquerda do verbo' para a esquerda da categoria que hospeda o clítico (Asp ou T, de acordo com o status do clítico se argumental ou não-argumental). ${ }^{139} \mathrm{D}, \mathrm{M} \& \mathrm{G}$ também assumem que parte da variação observada entre as línguas deriva-se do que elas chamam de Proclisis Parameter, ou seja, sugerem que a variação entre próclise e ênclise pode ser explicada interlinguisticamente e é obtida com fixação do valor negativo/positivo para o Proclises Parameter.

Assim, quando as línguas fixam o valor positivo 'sim' para o Proclisis Parameter, a próclise é o padrão dominante, já o padrão ênclise será dominante quando a língua fixa o valor negativo 'não' para o mesmo parâmetro. As autoras definem assim a configuração de tal parâmetro:

\section{Proclises Parameter}

- Os traços- $\varphi$ dos clíticos pronominais bloqueiam Agree e atraem operações de sonda de T: yes/no.

(D,M\&G, 2005, p. 122)

${ }^{139}$ D,M\&G seguem Sportiche (1998) e Shlonsky (2004). 
Outras diferenças entre as línguas românicas, em particular PE e PB, são explicadas a partir das propriedades dos nódulos $T$ e $A s P$, nomeadamente, suas habilidades para atraírem $V$ e/ou para checarem, através de Agree, traços não-interpretáveis, sem, no entanto, atraí-los (Attract) (op. cit., p. 114).

O nódulo clítico está associado com uma posição $\theta$ no domínio $v / \mathrm{V}$, mas a fim de que ele possa aplicar a sonda a cada um dos alvos relevantes, ele precisa ocupar uma posição acima de $v \mathrm{P}$ na estrutura funcional da sentença. $\mathrm{O}$ nó AsP imediatamente acima de $v \mathrm{P}$ poderia ser um forte candidato. Partindo da estrutura mínima da sentença proposta por Chomsky (2000, 2001), D,M\&G adotam a ideia de que o primeiro núcleo funcional acima de $\nu \mathrm{P}$ é Asp - o núcleo funcional locus para a checagem de traços de telicidade ${ }^{140}$ e marcas aspectuais. Nesse sentido, os clíticos poderiam estar hospedados em AsP, mas contra esse argumento, as autoras corroboram a tese já amplamente discutida de que construções participais não hospedam clíticos e que eles são concatenados no núcleo T. ${ }^{141}$

Abaixo seguem-se os quadros referentes às configurações de ênclise e próclise nas línguas românicas, segundo $\mathrm{D}, \mathrm{M} \& \mathrm{G}$ :

\footnotetext{
${ }^{140}$ Predicados télicos expressam uma eventualidade com ponto final natural em oposição a eventos atélicos que não têm ponto final.

${ }^{141} \mathrm{O}$ argumento de que o nó funcional que hospeda o clítico é inserido acima de AsP e selecionado por T, é reforçado com a constatação de que as sentenças participais não toleram clíticos.

Ex. Enviadas as flores ao vencedor do prêmio...

*Enviadas-lhes a flores, ... (exemplos retirados de D, M\&G, 2005, p. 123).
} 
Quadro 12 - Projeção para as colocações enclíticas românicas ${ }^{142}$

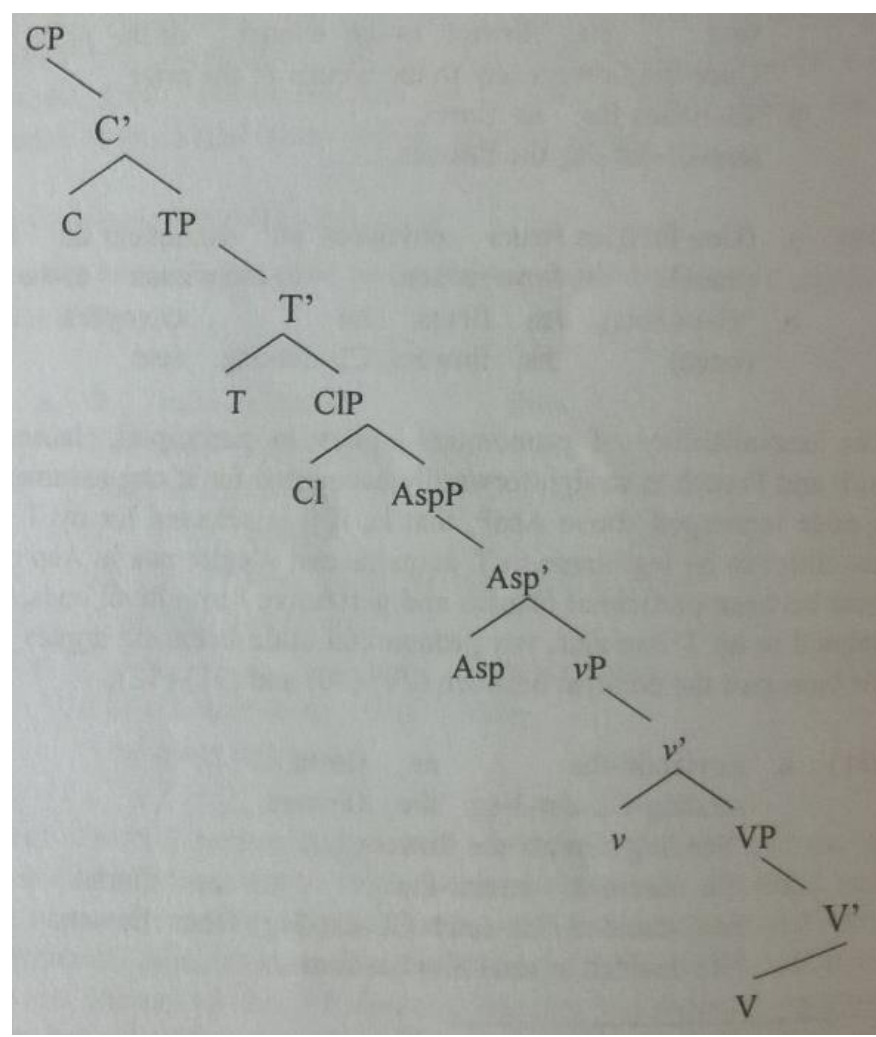

$\mathrm{D}, \mathrm{M} \& \mathrm{G}$ defendem que, em línguas que fixam o valor negativo para o Proclisis Parameter, como PE, o padrão geral é a ênclise uma vez que os traços- $\varphi$ dos clíticos pronominais não bloqueiam Agree e atraem (Attract) operações dirigidas pelos traços$\varphi$ do complexo T. Os traços funcionais dos clíticos pronominais nesse tipo de língua, segundo as autoras:

- bloqueiam a operação Agree, proibindo o subarranjo de traços temporais em T;

- bloqueiam a operação Attract da sonda T dirigida pelos seus traços temporais.

${ }^{142}$ Retirado de Duarte, Matos \& Gonçalves (2005, p. 124). 


\section{Quadro 13 - Projeção para as colocações proclíticas românicas ${ }^{143}$}

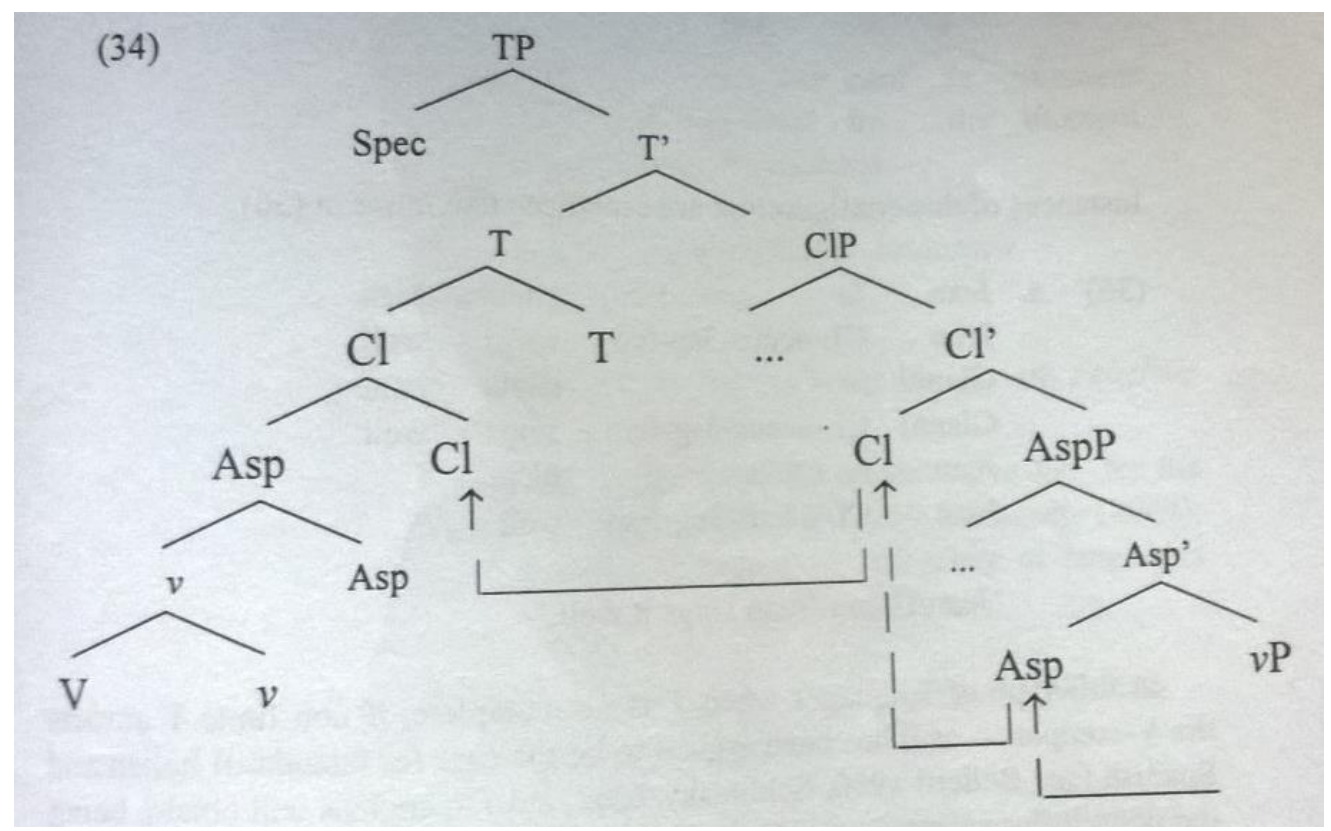

O quadro 13 ilustra as línguas que fixam o valor positivo para o proclisis parameter, casos em que ocorrem próclise.

As autoras explicam que, nas línguas que fixam o valor positivo para Proclisis Parameter, quando T é complemento, isto é, quando ele tem traços- $\varphi$ não interpretáveis para serem checados antes do 'complexo-V', e consequentemente marcado para apagamento (Chomsky, 2001, 2004), ele atrai V. Se um clítico está presente seus traços- $\varphi$ bloqueiam a operação Agree que necessita tomar lugar entre a sonda T e o alvo Asp/v/V. (D,M\&G, 2005, p. 125).

Se os traços não interpretáveis em T permanecem não checados, a derivação falha. Como último recurso, uma derivação alternativa em que o alvo Asp/v/V move-se para $\mathrm{T}$, saltando o núcleo clítico, torna isso possível para a operação Agree entre a sonda de T e seu alvo. Finalmente, o núcleo complexo T/Asp/v/V atrai o clítico, obtendo a próclise. O núcleo funcional $\mathrm{Cl}$ é checado antes de $\mathrm{V}$ e marcado para apagamento. Nesses passos da derivação, os traços não interpretáveis de $\mathrm{V}$ (hospedeiro) do núcleo funcional do clítico - CL - é checado antes de $\mathrm{V}$ e marcado para apagamento.

${ }^{143}$ Retirado de Duarte, Matos \& Gonçalves (2005, p. 125). 
Assim, ao final da derivação, o clítico adjunge-se à esquerda de T, corroborado pela marcação positiva do Proclises Parameter. Nesses casos, a operação Agree valora finalmente os traços formais dos pronominais.

Quando as operações de aplicação de sonda de T e operadores de Attract de núcleos de sintagmas, os traços- $\varphi$ também bloqueiam a operação de Attract.

No PE, como a marcação é negativa para o Proclisis Parameter, a próclise ocorrerá na presença de operadores próclise, sob c-comando local, como operação de último recurso para a derivação da de próclise: ${ }^{144}$

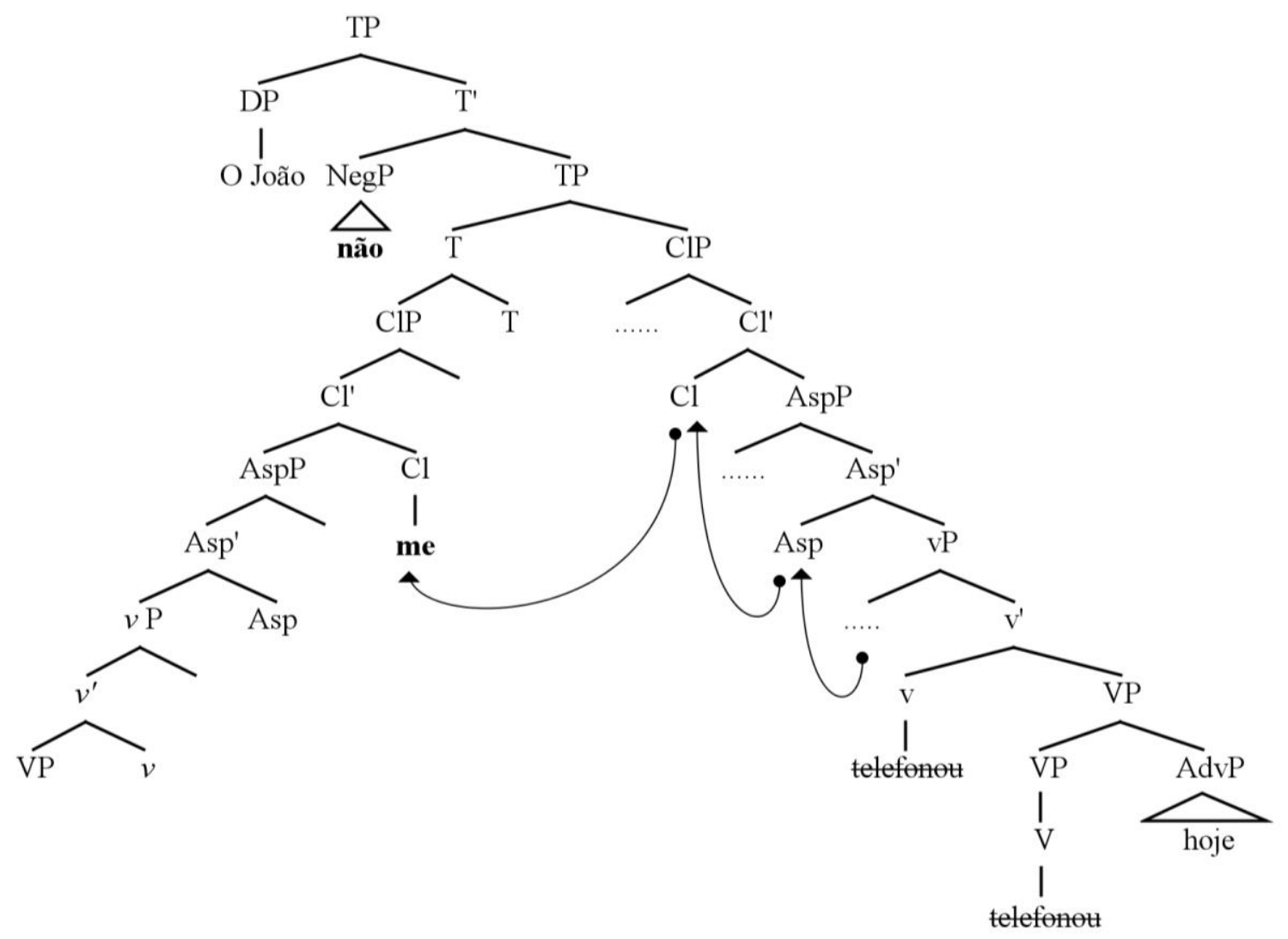

O operador de negação sentencial, hospedado no núcleo $N e g$ em adjunção à esquerda de T c-comanda o núcleo funcional $\mathrm{Cl}$, selecionado por TP.

Seguindo a tipologia de Déchaine \& Wiltschko (2002) as autoras assumem que os pronominais quando clíticos ou proclíticos são unidades lexicais do nível das palavras:

we assume that these elements, whether enclitic or proclitic, are lexical units of word level, consisting of a bundle of $\varphi$-features, which do to their (phonologic and syntactic) deficient status, require a specific host. Additionally, we assume that clitics are merged in the syntactic derivation

${ }^{144}$ Projeção inspirada na proposta de D,M\&G (2005). 
in a fixed position of the clause architecture, as suggested in Sportiche (1988) and Schlonsky (2004). ${ }^{145}$

(D,M\&G, 2005, p. 118)

\subsubsection{As projeções estruturais de ênclise e próclise em $P B^{146}$}

Antes de apresentar os pressupostos que delineiam os padrões de colocação clítica no PB, retomo a tipologia dos clíticos no PE de B,D\&M (2003), apresentada anteriormente, (seção 2.4.4), e que sinaliza uma diferença expressiva entre o PB e o PE, levando em consideração que estas propriedades funcionam como uma 'linha de corte' na classificação que B,D\&M (2003) fazem dos clíticos no PE. O fato de o clítico poder ou não redobrar e poder ou não ser simultaneamente extraído é, na verdade, o principal teste que as autoras utilizaram para propor uma tipologia clítica.

Relativamente aos traços dos clíticos no PE, apresento suas possibilidades no PB:

(i) o potencial referencial ou predicativo; ${ }^{147}$

(ii) a possibilidade de receber papel temático;

(iii) a possibilidade de modificar a grade argumental do verbo;

(iv) a possibilidade de veicular referência específica ou arbitrária.

Diferentemente do PE, como dito acima, nas variedades [+/- marcadas] e [não marcadas] de português brasileiro - ver continuum (cap. 1, seção 1.5), a próclise configurase como a ordem não-marcada da cliticização. Os contextos de atração de próclise do PE tornam-se pouco aplicáveis ou inaplicáveis para as formas padrão e não padrão do português brasileiro. Alguns exemplos de variação próclise/ênclise em variedades nao marcadas do PB atestam esse fato em construções com auxiliares verbais e de controle, por exemplo:

(65) a. Não vou deixá-lo sozinho - PB/ *PE

b. Não quero deixá-lo sozinho - PB/ *PE

\footnotetext{
145 Tradução aproximada: “Assumimos que esses elementos, se enclíticos ou proclíticos, são unidades lexicais de nível de palavra, que consiste em um conjunto de traços- $\varphi$, que representam/portam o seu status (fonológico e sintático) deficiente, necessitando de um hospedeiro específico. Além disso, assumimos que clíticos sofrem Merge na derivação sintática em uma posição fixa na sentença, como sugerido em Sportiche (1988) e Schlonsky (2004).

146 Nesta subseção a sigla PB está relacionada à variedade [- Marcada] de português conforme o continuum dialetal de português proposto no capítulo 1, seção 1.5.

${ }^{147}$ Se consideramos a tese mais estrita de que os falantes do português brasileiro não produzem mais clíticos de $3^{a}$. pessoa em sua gramática, o potencial referencial ou predicativo clítico também sofre alteração.
} 
(66) a. Não o vou deixar sozinho PE / ? PB

b. Não o quero deixar sozinho PE / ? PB

Em todas as sentenças acima, por serem negativas, a próclise é obrigatória em PE. No entanto, a negação em todas as variedades de PB não é necessariamente o elemento de atração ao clítico, ainda que o exemplo em (67 a), abaixo, possa sugerir essa ideia, face a (67 b): ${ }^{148}$

(67) a. Não $o$ estava vendo

b. Não estava $o$ vendo

segundo Galves (2001a, p. 135), os falantes brasileiros preferem a construção (67 a) acima, ou seja, que o clítico fique em próclise à forma verbal flexionada nas locuções gerundivas e participais - e não, necessariamente, por conta do 'fator negação'. Nos exemplos (67) acima, em PE, por outro lado, há dupla razão para a próclise: (i) por se tratar de oração negativa, a próclise é obrigatória, e (ii) as construções sintáticas auxilar+infinitivo, que formam um predicado complexo, são ambientes sintáticos próprios para a 'subida de clítico'. No entanto, em $\mathrm{PB}$, nenhum dos contextos sintáticos (i)-(ii) parece ser suficiente para a obrigatoriedade da próclise - aliás, a subida de clítico nem mesmo é legitimada em PB (cf. Cyrino, 2010).

Em contextos afirmativos, como se viu na seção (2.4.4), a próclise é desencadeada em PE pela presença de operadores; além de haver casos de variação entre a próclise e a ênclise (com os advérbios focalizadores ali e rapidamente e com a palavra próprio): ${ }^{149}$

(68) a. Eu próprio lhe dei a notícia.

b. Eu próprio dei-lhe a notícia.

Outra variação entre PE e PB diz respeito ao uso de pronomes lexicais como complementos, pois, como se sabe, esse uso é licenciado apenas em PB e é completamente agramatical em PE.

(69) Eu vi ele ontem - PB/*PE

O padrão proclítico do $\mathrm{PB}$ que, à primeira vista, assemelha-se às línguas citadas anteriormente, parece compartilhar com elas de apenas algumas características, afastando-se

\footnotetext{
${ }^{148}$ Exemplos retirados de Galves (2001a, p. 135, renumerados).

${ }^{149}$ Exemplos retirados de Martins (2013, p 2242, renumerados).
} 
delas e inserindo novas alternativas no quadro de colocação pronominal no domínio românico.

A seguir, apresento as projeções de próclise e de ênclise em PB baseadas nas propostas de Galves (2001a) e Galves\&Abaurre (2002 [1992]). Em PB, como já mencionado não há operador de próclise, pelo menos nos termos de PE, pois nem mesmo a negação legitima a próclise em PB. Mesmo os textos escritos, costumam cometer 'desvios' quanto ao padrão rígido de colocação obrigatoriamente proclítica em PE, a título de exemplo, repito o excerto já discutido no capítulo 1, seção 1.2:

(1) Não há outro motivo, aliás, para muitas das atividades a que se dedicam, dedicaram-se e dedicar-se-ão quaisquer governantes em qualquer tempo e lugar do mundo: fazer discursos, participar de eventos, comparecer a inaugurações das obras que construíram ou não. (Folha de São Paulo, Opinião, Editoriais, 03.02.14)

(i) As projeções estruturais de próclise em $P B$

As análises de Galves (2001a,b) e Galves \& Abaurre (2002) baseadas em dados do NURC levaram as autoras a postularem a próclise (ao verbo que atribui papel temático) como regra geral no PB.

A análise das autoras é centrada na natureza do clítico e pode ser assim definida: (i) os clíticos do PB são os de $1^{\mathrm{a}}$. e $2^{\mathrm{a}}$. pessoas; (ii) todos os clíticos do PB são tratados como XPs (clíticos fortes, nos termos de Uriagereka, 1992) - e, claro, se movem como sintagmas; (iii) o português brasileiro é composto basicamente por próclise (a ênclise é marginal).

G\&A consideram que não há cliticização ao núcleo $T$, mas à projeção que contém imediatamente o verbo que atribui (ao clítico) papel temático, ou seja, adjunção a T’ ou Asp', sejam as orações com um único verbo ou com locuções verbais.

Nos quadros 14 e 15, a seguir, apresento as representações para as frases proclíticas no português brasileiro, propostas por G\&A (2002, p. 290). 
Quadro 14 - projeção de próclise em PB em períodos simples

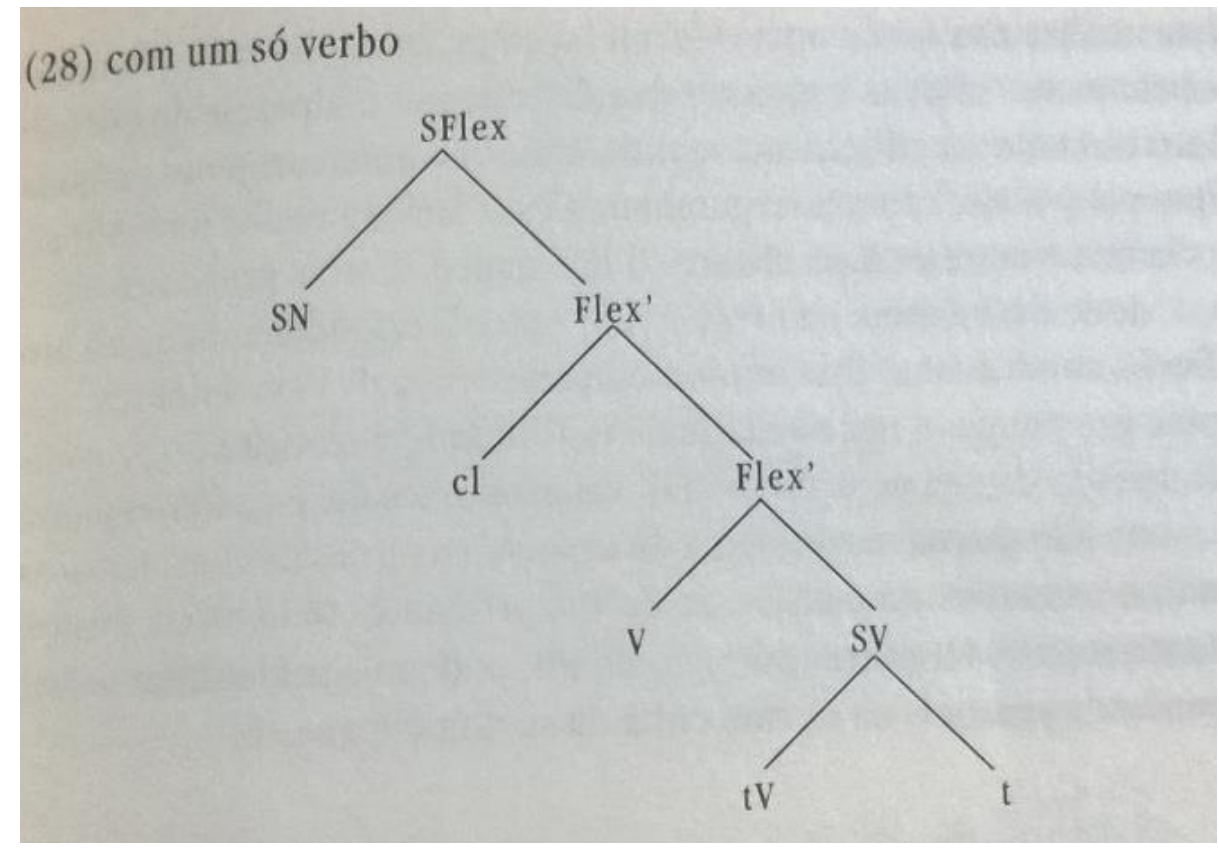

Na projeção do quadro 14 , com um só verbo, o clítico (de $1^{\mathrm{a}}$. ou $2^{\mathrm{a}}$. pessoa) é adjungido à projeção intermediária de $\mathrm{T}$, como um XP deslocado.

\section{Quadro 15 - projeção do período composto em PB: próclise/ênclise}

(29) com locução verbal

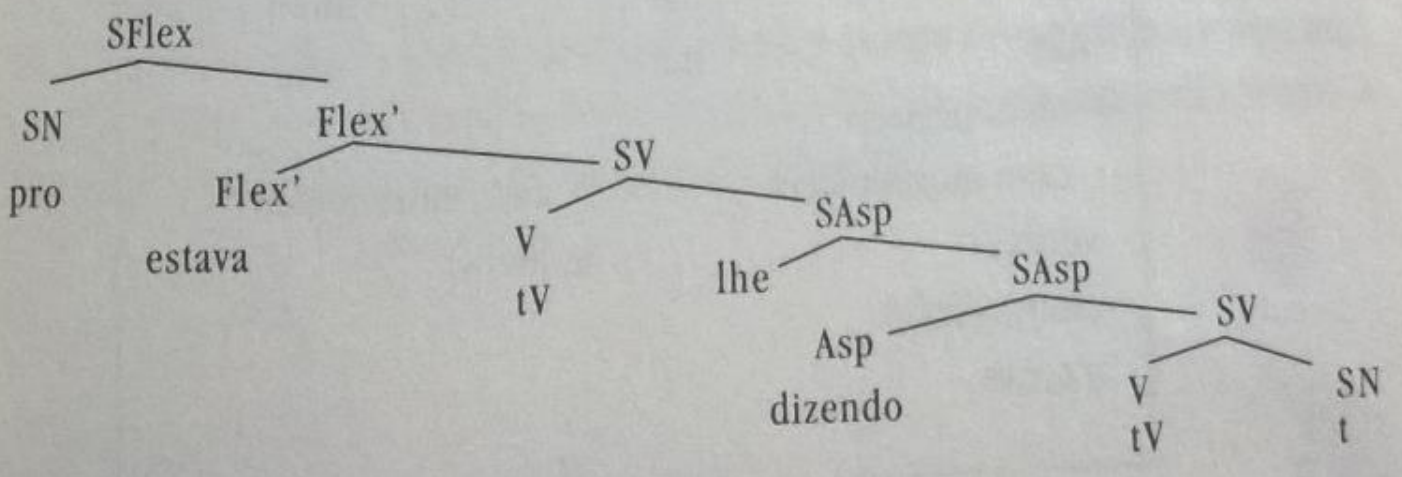

Na projeção do quadro 15 , com locução verbal, o clítico adjunge-se à esquerda da projeção mais alta do nódulo Asp.

(ii) As projeções estruturais de ênclise em $P B$ 
Para G\&A (2002, p. 294) a ênclise é 'um caso marcado' em PB. A análise das autoras tem como ponto de partida o desaparecimento dos clíticos $o$, $a$ (op. cit., p. 293). No entanto, tal desaparecimento não é absoluto, pois há falantes que produzem esses clíticos (ainda que marginalmente). Portanto, eles são adquiridos durante a escolarização e integrados ao léxico tardiamente (op. cit., p. 294). Para as autoras o uso da ênclise pode também ser atribuído ao contato com a escrita.

Nas análises de G\&A, os clíticos $o$, $a$, nas construções com locução verbal, aparecem proclíticos ao auxiliar (Não o tinha visto) e, nesse caso, está adjungido a T, conforme quadro 15; nas infinitivas (casos mais comuns de ênclise) os clíticos $o, a$ ocorrem em ênclise ao verbo não finito (eu queria vê-lo). As autoras analisam a ênclise como um caso de afixação do clítico à direita do nódulo flexão contendo o verbo no infinitivo. Elas hipotetizam a existência de Flex nas orações infinitivas (dada a existência do infinitivo flexionado em português).

Em (70), baseio-me em G\&A (2002[1992]) para a projeção da ênclise, mas de modo simplificado, em adjunção a Asp.

(70) Eu queri vê-lo

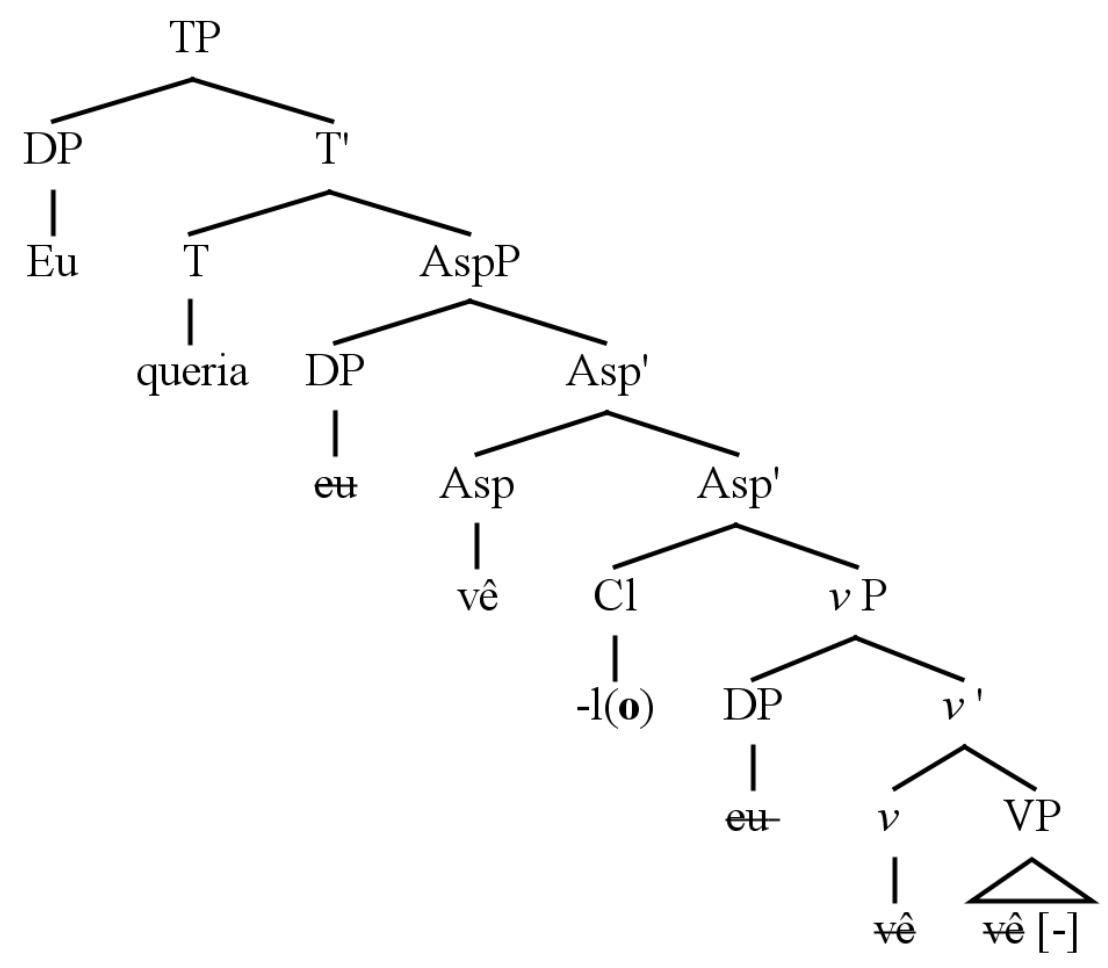

Para finalizar essa seção, retomo algumas análises de Galves (2001a) e G\&A (2002 [1992]) em relação ao PB falado, cuja principal constação é: “os clíticos de terceira pessoa 
são vestígios na língua e não são mais produzidos pela gramática nuclear da língua”. Para a Gramática de Jurussaca, que se trata de variedade [+marcada] (cf. o continuum proposto no cap. 1), provavelmente, nem mesmo se possa postular que os clíticos de terceira pessoa sejam vestígios, nos termos das autoras, uma vez que são totalmente ausentes da fala dos mais velhos.

\subsection{Da existência de pronome fraco em PB}

A tradicional oposição binária dos pronomes pessoais representada pela dicotomia entre pronomes átonos e tônicos ou clíticos e tônicos foi reanalisada com o estudo de Cardinaletti e Starke (1999) cujos autores propuseram uma tripartição dos pronomes em fortes e fracos e clíticos como apresentado na subseção 2.4.3.2.

Estudos que antecederam a proposta de revisão tipológica de Cardinaletti e Starke (op. cit.) verificaram algumas peculiaridades no padrão de colocação clítica das línguas românicas. Uma peculiaridade da língua francesa (e também de dialetos do norte de Itália) é quanto à existência de pronomes clíticos sujeitos (inexistentes no italiano, no espanhol e no português $)^{150}$.

Uma das constatações feitas por Kayne (1975, ps. 97, 98, 100) é que os pronomes clíticos sujeitos do francês, em construções coordenadas de sujeito compartilhado, permitem a elipse no segundo termo, em oposição ao que ocorre com os clíticos objetos desta mesma língua. Esses pronomes clíticos sujeitos foram reanalisadas por Cardinaletti \& Starke (1999) como pronomes fracos em vez de clíticos.

Para Cardinaletti e Starke (op. cit.), pronomes clíticos sujeitos, como descritos por Kayne (1975) que podem ser omitidos no segundo VP coordenado são, na verdade, pronomes sujeitos fracos, daí o contraste entre pronomes sujeitos fracos e clíticos objetos. Os primeiros podem ser omitidos e os segundos não.

Galves (2001b, p. 162), seguindo a proposta da tripartição pronominal (Cardinaletti \& Starke, 1999) analisou o estatuto do pronome complemento 'ele' em exemplos como (71) abaixo, considerando-o um pronome fraco em vez de tônico. Mas Galves levanta um problema que surge com tal análise: pronomes fracos não podem ocupar estruturas de base.

${ }^{150} \mathrm{O}$ pronome clítico 'se' prece ser o único pronome clítico sujeito do português. 
A autora resolve o problema, analisando tais ocorrências do pronome fraco como estruturas derivadas em PB. ${ }^{151}$

(71) Deixei ele em casa - PB/*PE

Também Peterson (2008), ao analisar a proforma de terceira pessoa 'cê' do PB, lança mão à mesma restrição utilizada por Cardinaletti \& Starke (1999) para defender que tal pronome no PB é fraco e não clítico como defendem Vitral (1996) e Ramos (1997).

(72) $C \hat{e}$ come bolo e _ bebe refrigerante todo dia. ${ }^{152}$

Com base na restrição quanto à obrigatoriedade de repetição dos clíticos em VPs coordenados, observada por Cardinaletti \& Starke (op. cit.) para o francês, Peterson, então, descarta a análise de 'cê' como clítico e compara-o ao 'il' do francês, classificando-o como pronome fraco, pois em (73): “cê afasta-se do padrão de comportamento dos clíticos, já que como clítico sujeito, seria esperado que, para a sentença em (72) ser gramatical, obrigatoriamente houvesse a repetição deste pronome no segundo VP coordenado". (Peterson, 2008, p. 15).

No capítulo destinado à análise do corpus retomo a proposta de tripartição pronominal que parece ser pertinente ao padrão de colocação pronominal na comunidade de Jurussaca.

\subsection{Sintese do capítulo}

Neste segundo capítulo apresentei o estatuto dos pronominais clíticos com base em uma resenha dos principais estudos no campo da sintaxe, partindo da classificação tradicional para chegar aos pressupostos da teoria gerativa. Justifiquei a minha opção pela escolha de um quadro teórico formal por entender que as peculiaridades configuracionais do item pronome pessoal, escopo central da tese, requerem 'ferramentas' que permitam investigar melhor as suas possibilidades morfossintáticas e semânticas relativamente à forma, à colocação, à referencialidade etc. Assim, abordei os aspectos referentes ao tratamento das pro-formas pronominais a partir da Teoria de Regência e Ligação na Versão de Princípios e Parâmetros e na versão mais recente da teoria, o quadro do Programa

${ }^{151}$ Exemplo retirado de Galves (2001b, p. 163, renumerado).

${ }^{152}$ Exemplo retirado de Peterson (2008, p. 15, renumerado). 
Minimalista. Também foram discutidas as abordagens teóricas propostas para análise dos pronominais clíticos nas línguas românicas, de modo geral e, em particular, o seu estatuto no PE e no PB.

A finalidade principal do capítulo foi apresentar um quadro geral do state of the art da categoria pronomial, apontado para a proposta de análise que melhor se adequa aos dados a serem analisados no capítulo 3. 


\section{Capítulo III}

Para uma análise da expressão prominal do português afroindígena de Jurussaca

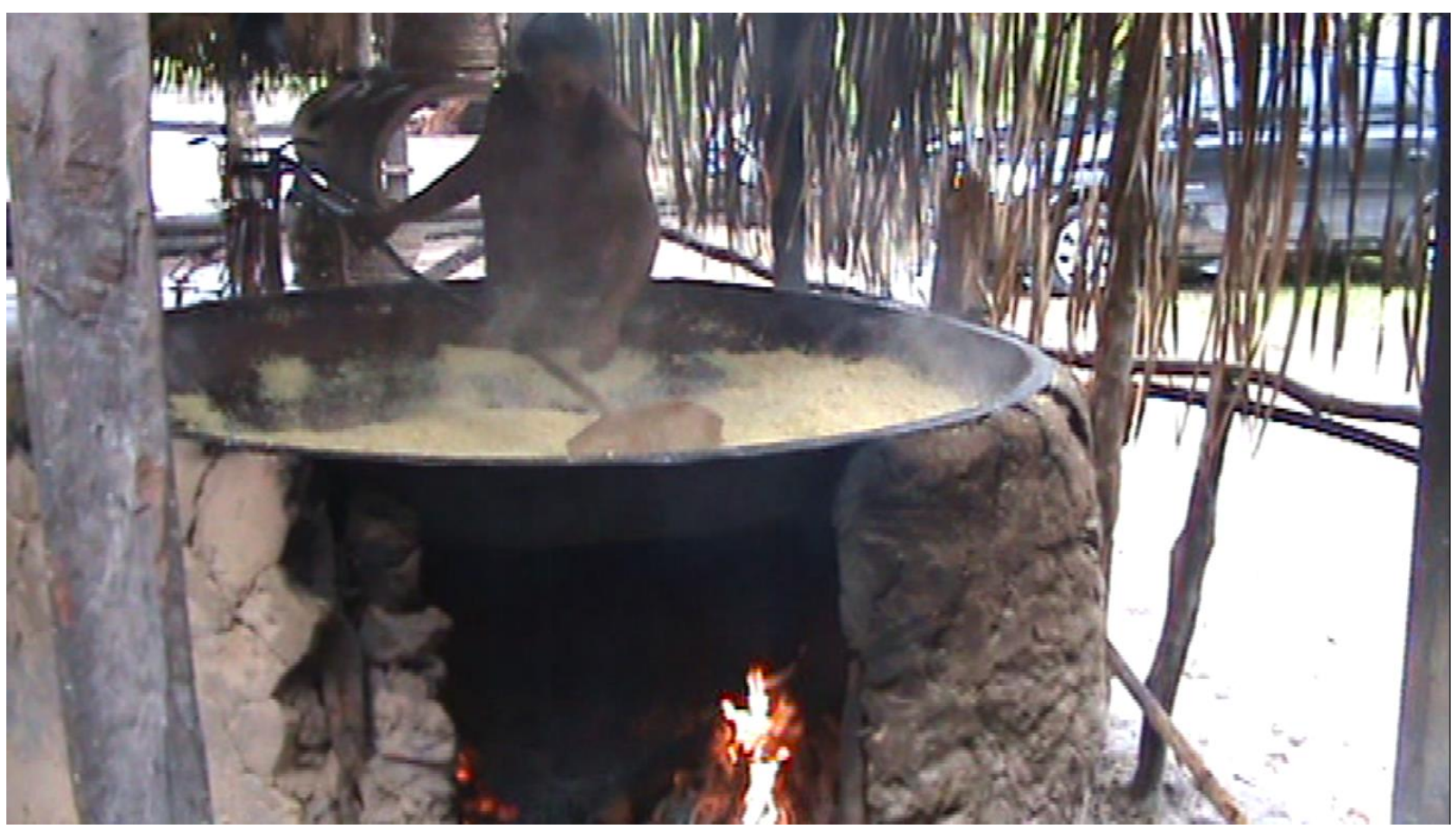




\subsection{Introdução}

Neste terceiro capítulo, faço considerações sobre os corpora seguidas de um breve histórico da região onde estão localizadas as cidades de Tracuateua e Bragança, bem como a comunidade de Jurussaca. Apresento um pouco da história da região, da cultura e dos processos migratórios.

Em seguida, passo à análise dos dados com base na fundamentação teórica apresentada no capítulo 2 .

Proponho um quadro geral da expressão pronominal da comunidade e passo à abordagem dos aspectos que analisarei mais detidamente:

(i) o estatuto do pronome nós e sua colocação pré-verbal;

(ii) o estatuto dos pronomes atemáticos eu e ele em construções como: eu não sei não eu ele é de cobre ele;

(iii) o estatuto morfossintático do pronome lhe em construções como: ele deulhe nela;

(iv) o clítico inerente e o clítico atemático em construções do tipo: ela nasceu e se criou-se aqui;

(v) a pro-forma pronominal esse um, essa uma.

Para a análise de construções pronominais clíticas, retomo a literatura resenhada no capítulo 2 quanto as colocações do clítico nas línguas românicas e a literatura sobre a pronominalização relevante para as operações sintáticas em análise.

\subsection{Apresentação da comunidade}

\subsubsection{A comunidade de Jurussaca: aspectos sócio-históricos}

A comunidade de Jurussaca está localizada na região nordeste do Estado do Pará. No mapa do estado do Pará, abaixo, com destaque para a Região Costa Atlântica, no nordeste do Estado, estão localizados os municípios de Bragança e Tracuateua (Tracuateua em vermelho e Bragança a sua direita), bem como a comunidade quilombola de Jurussaca: ${ }^{153}$

\footnotetext{
${ }^{153}$ Mapa retirado do site:http://pt.wikipedia.org/wiki/Ficheiro:Para_Municip_Tracuateua.svg.
} 
Mapa 1 - Localização dos municípios próximos a Jurussaca

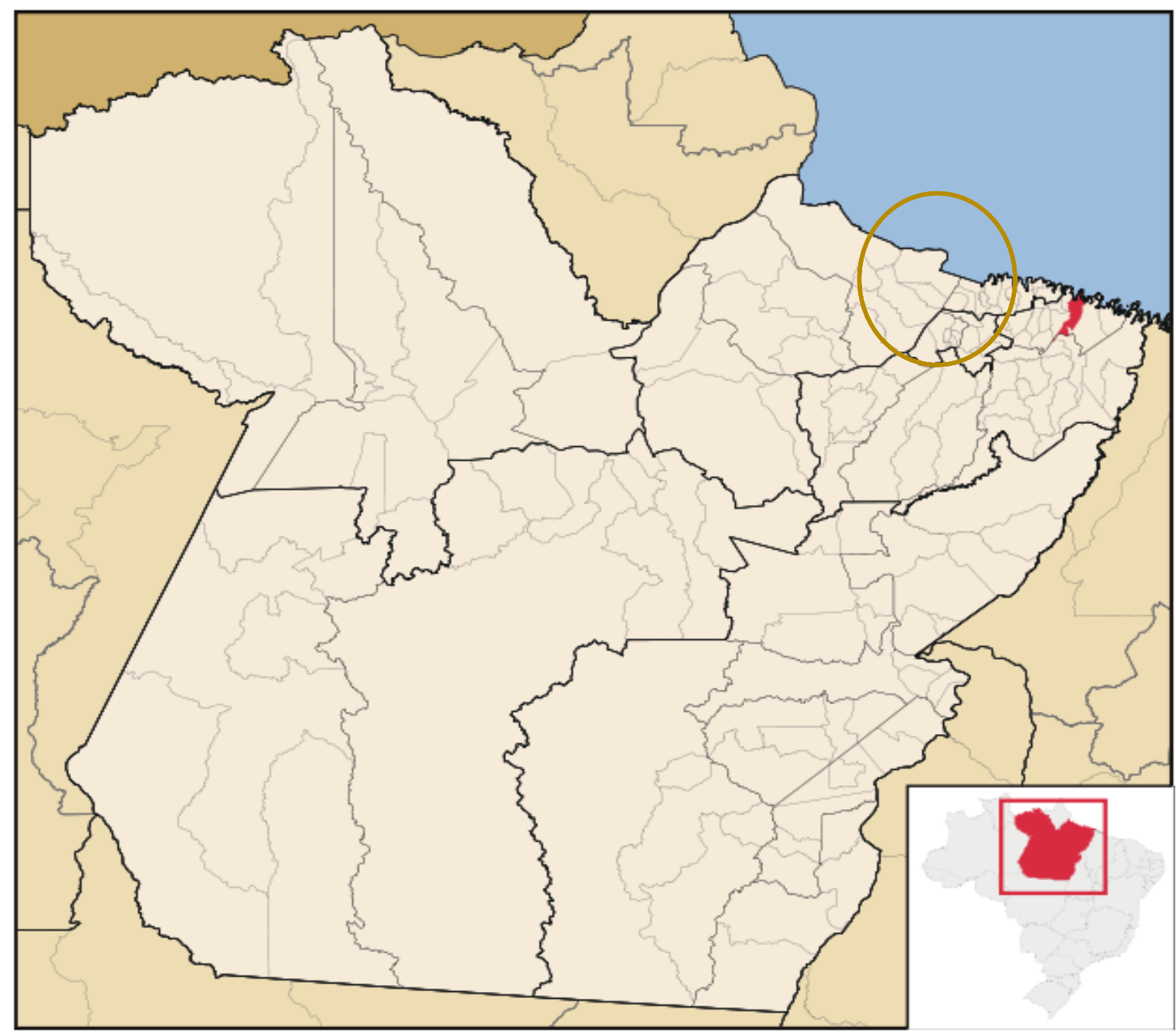

A cidade de Bragança é uma das mais antigas da região. Foi o primeiro polo de ocupação europeia da Amazônia. Sua história começa no século XVI e, em 1753, foi transformada em freguesia com o nome de Nossa Senhora do Rosário. Um ano depois, a freguesia foi elevada à categoria de vila, com o nome de Vila Nossa Senhora do Rosário de Bragança. ${ }^{154}$

Já Tracuateua, povoado pertencente à Bragança, foi transformado em município em 1995. O nome do município tem origem na palavra indígena tracuá (uma espécie de formiga) e teua (topônimo de origem tupi). ${ }^{155}$

A comunidade de Jurussaca, um dos 253 'povoados quilombolas' do estado do Pará (cf. estudos de levantamento cartográfico do NAEA/UFPA), localizada anteriormente nas

\footnotetext{
${ }^{154}$ Retirado de Bragança (2014).

${ }^{155}$ Retirado de Tracuateua (2014).
} 
terras de Bragança, tornou-se em 1995, parte de Tracuateua, com a elevação deste à categoria de município.

A comunidade de Jurussaca é - de acordo com NAEA (Núcleo de Altos Estudos da Amazônia) - um dos 253 povoados quilombolas distribuídos em oito áreas do Estado do Pará. As áreas quilombolas do Pará foram delimitadas pelo NAEA a partir de macro-regiões do Estado, como se vê no mapa das regiões hidrográficas do Pará:156

\section{Mapa 2 - Macro regiões hidrográficas do Estado do Pará}

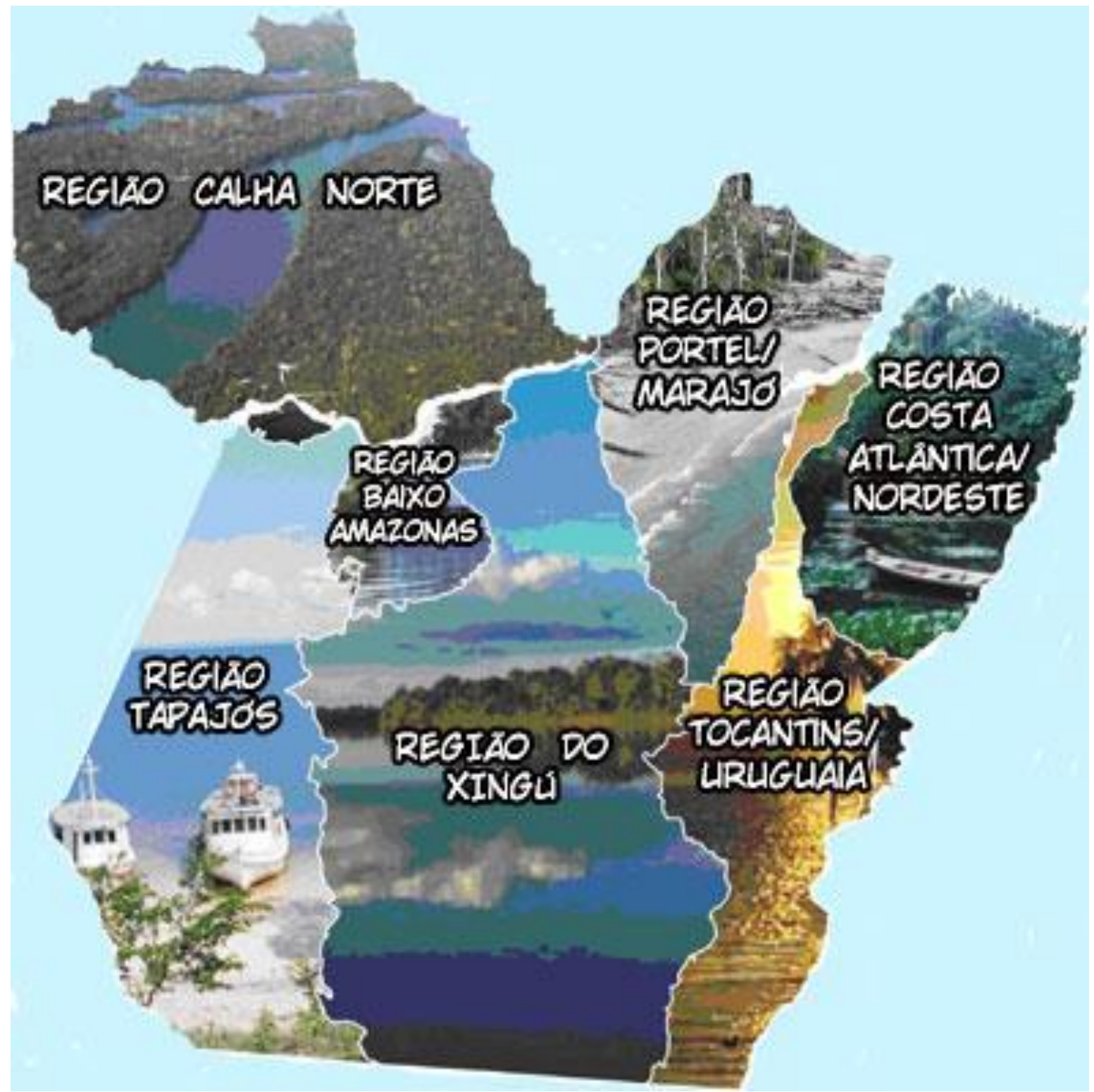

${ }^{156}$ Retirado de Para 30 Graus: Recursos Hídricos (2012). 
Jurussaca situa-se na região bragantina, Costa Atlântica/Nordeste, e encontra-se a aproximadamente $25 \mathrm{~km}$ da cidade de Bragança e a $10 \mathrm{~km}$ da cidade de Tracuateua. Segundo os relatos de seus moradores, a comunidade foi fundada por quatro escravos fugidos do Maranhão que ali se estabeleceram.

No mapa a seguir, vê-se "imagem Google” de localização parcial da comunidade na área do Município de Tracuateua

\section{Mapa 3 - Localização de Jurussaca}

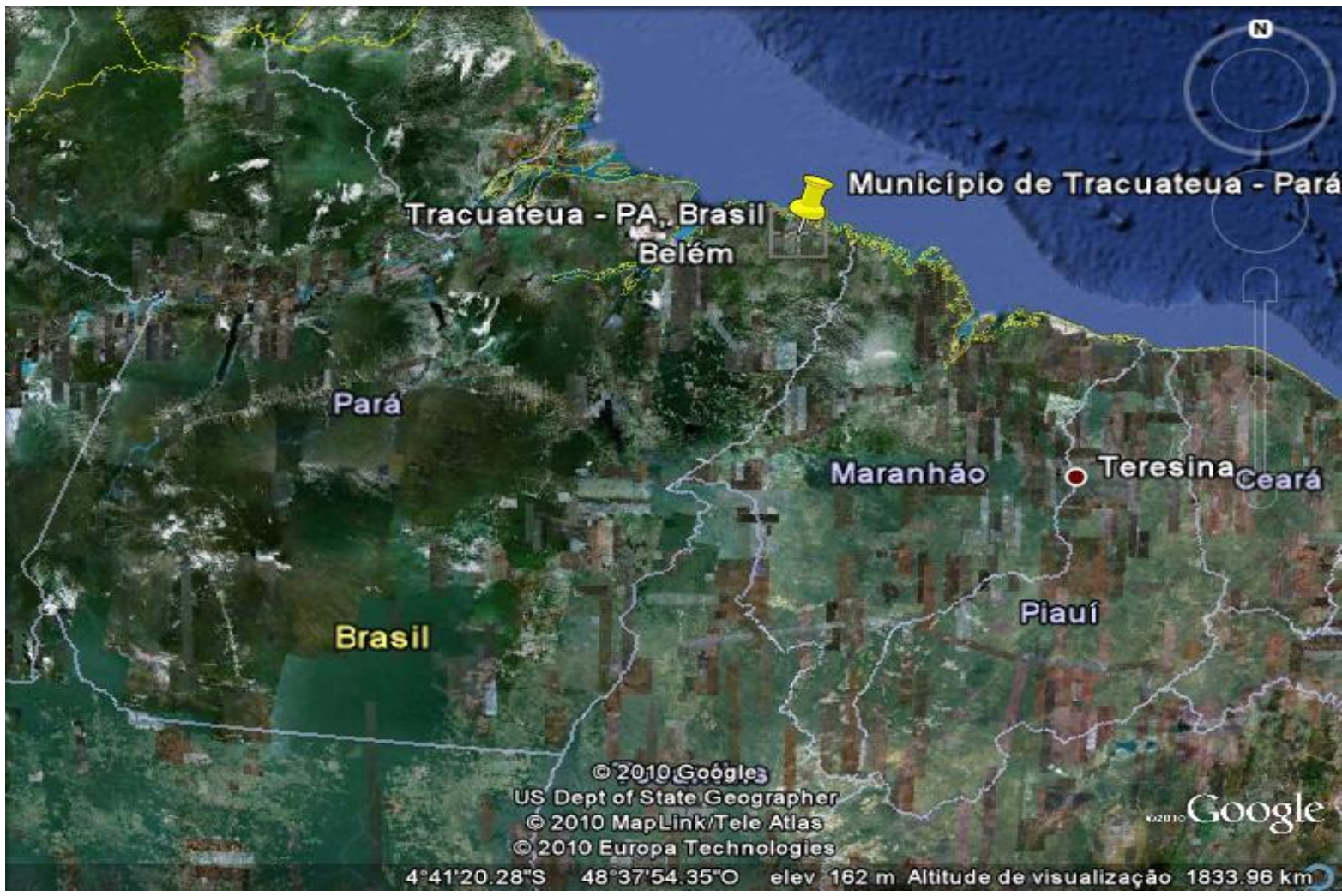

A população de Jurussaca se constitui de 500/600 pessoas que moram em aproximadamente 90 casas construídas por quase toda a extensão de uma área que soma um total de 200,9875 ha - a comunidade tem posse coletiva da terra. Para maiores detalhes sobre Jurussaca, ver (PETTER \& OLIVEIRA, 2011a). 


\title{
3.2.2. Sobre a constituição étnica de Jurussaca
}

A região bragantina onde a comunidade está localizada foi habitada outrora por índios da etnia Cariambá liga ao tronco Tupinambá ou Tupi. Esses povos foram, possivelmente, os primeiros habitantes da região bragantina (cf. Cecim, 2014, p. 16).

Sobre a miscigenação que provavelmente ocorreu entre os primeiros habitantes de Jurussaca e indígenas da região, é interessante observar o que pensam as pessoas dalí sobre o assunto. No relato de uma moradora, ela diz: 'minha avó era índia', ${ }^{157}$. Os traços fenotípicos dos indivíduos da comunidade também apontam para relações de contato entre essas etnias. Sobre esse aspecto, é interessante retomar alguns fatos apontados no capítulo 1, seção 1.3., relativamente aos fenômenos de contato forjados entre as diferentes etnias na formação de mocambos e quilombos na Capitania do Grão-Pará, apontados por Gomes (1997).

Segundo Gomes (op. cit., p. 28) nesta região, especialmente no Amapá, os mocambos também foram aumentados com as constantes deserções de soldados: “(...) outro fato discutido nesta Capitania é o movimento de fugas e o surgimento de 'mocambos de índios', destacadamente a partir de 1760" (op. cit., p. 28). Gomes cita ainda documentos indicando a formação de mocambos de negros e índios e as relações destes com povoados nas fronteiras.

Outro estudo importante sobre o negro na Amazônia, feito por Salles (2004), discute o papel do negro na formação da sociedade paraense e traz dados sugestivos sobre a miscigenação de que venho tratando:

\begin{abstract}
A fuga, na Amazônia, deve ter sido solução bastante difícil e arriscada. Na floresta o negro achava-se sozinho. Às vezes conseguia chegar a alguma aldeia indígena e, por sorte, acabava vivendo com os silvícolas. Integravase, desta forma, num grupo estranho e que, com ele, só tinha um traço comum: o ódio ao branco dominador. Há na crônica da escravidão muitos casos ilustrativos e que destroem o mito da incompatibilidade étnica. Nina Rodrigues fala, por exemplo, dos negros fugidos que em 1772, aliados aos índios atacaram a povoação de São José do Maranhão e, em represália foram massacrados. Há casos de negros liderando grupos indígenas, não poucos se tornaram chefes de tribos, tuxauas.
\end{abstract}

(SALLES, 2004, p. 85)

$\mathrm{Na}$ área quilombola de Jurussaca, para além de seus fundadores, provavelmente, escravos fugidos, a região era também habitada por indígenas. A etnolinguística da comunidade vem sendo atestada como afro-indígena (cf. Oliveira et alii (no prelo), Oliveira \& Praça (2013), Antunes, Oliveira \& Praça (2013). Baseando-se na morfologia territorial da

${ }^{157}$ Referente ao relato de D. Fausta, moradora da comunidade, de 65 anos. 
comunidade, Cecim $(2014$, p. 81$)$ aponta que a área fora habitada por indígenas do tronco Macro-Jê.

Cecim (2014) levanta a tese, baseada na morfologia territorial da comunidade, de que haja uma "Ligação Indígena Jê" na sua formação:

"O que nos chama a atenção, em nossa pesquisa em Jurussaca, é que a morfologia territorial da comunidade se assemelha a de alguns aldeamentos indígenas, localizados em várias regiões do Brasil, inclusive na Amazônia, como os Timbiras, os Kraôs, também reconhecidamente como povo Timbira - ver Ladeira (2012: 24) -, e os Xavantes.”

(CECIM, 2014, p. 19)

Cecim, citando Ladeira, (2012, p. 19), atesta que nas aldeias localizadas no cerrado brasileiro do sul do Maranhão ao norte do Tocantins, as casas desses povos indígenas ficam dispostas em um círculo, cujo centro é uma área também circular e limpa, como se pode ver nas figuras 1 e 2 baixo, de aldeias do tronco Jê:

Figura 3 - Aldeias do tronco Jêe $\hat{e}^{158}$

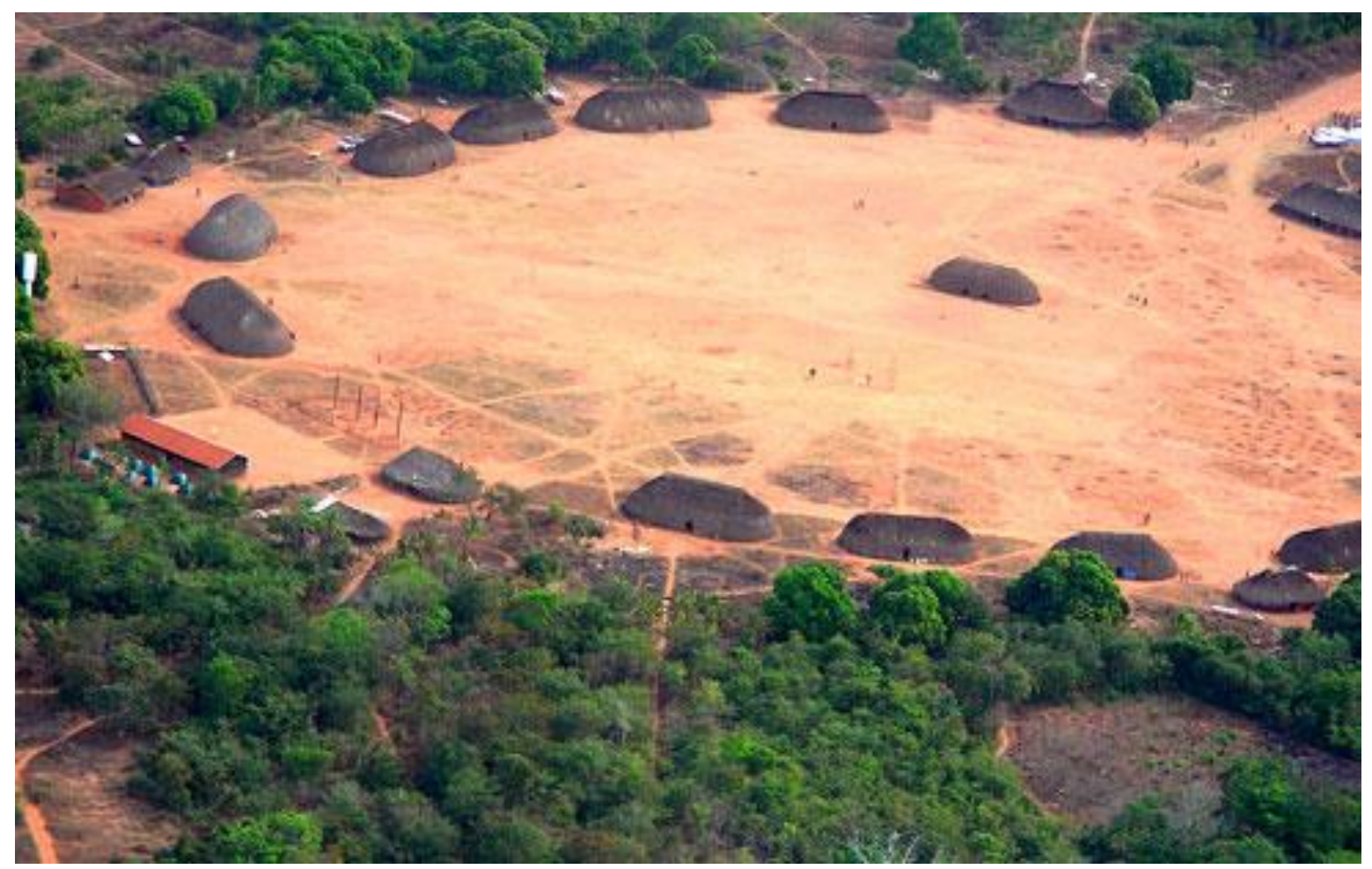

Uma comparação da figura 3, acima, com as figuras 4 e 5, a seguir, traz à mostra uma interessante relação entre as aldeias do tronco Jê e a comunidade de Jurussaca. Essa simetria é apresentada por Cecim (2014, p. 23) como uma hipótese de contato linguístico

${ }^{158}$ Foto retirada de Cunda (2009). 
entre Jurussaca e grupos indígenas a partir de um forte indício baseado na 'morfologia territorial', indicando que a comunidade pode ter em sua gênese grupos indígenas Jê como um de seus substratos.

A comunidade de Jurussaca é composta por duas subáreas: subárea Jurussaca e subárea Cebola, confore as figuras: ${ }^{159}$

\section{Figura 4 - Croqui da subárea Jurussaca}

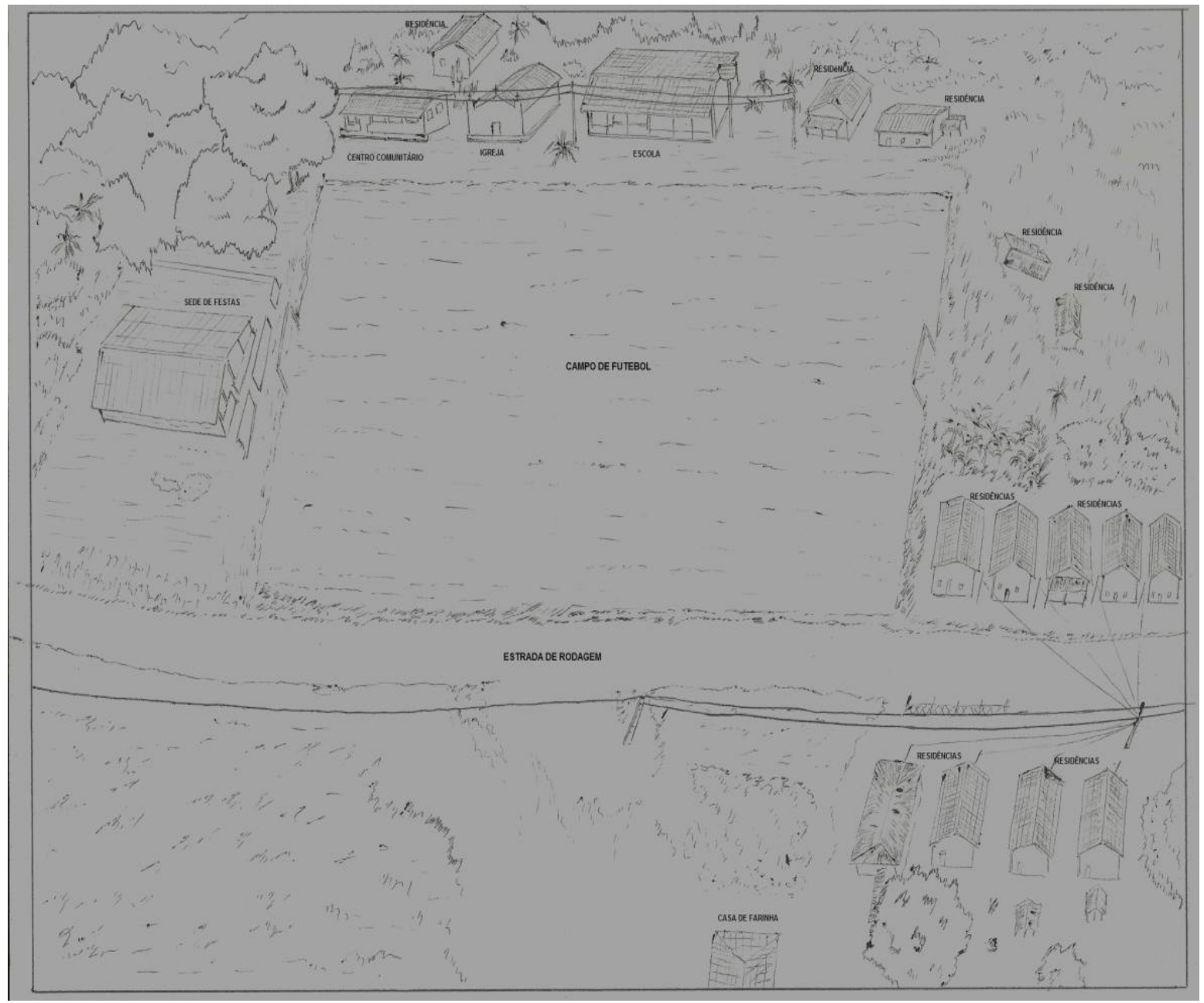

${ }^{159}$ Figuras retiradas de Cecim (2014, ps. 23 e 24, renumeradas). 


\section{Figura 5 - Croqui da subárea Cebola}

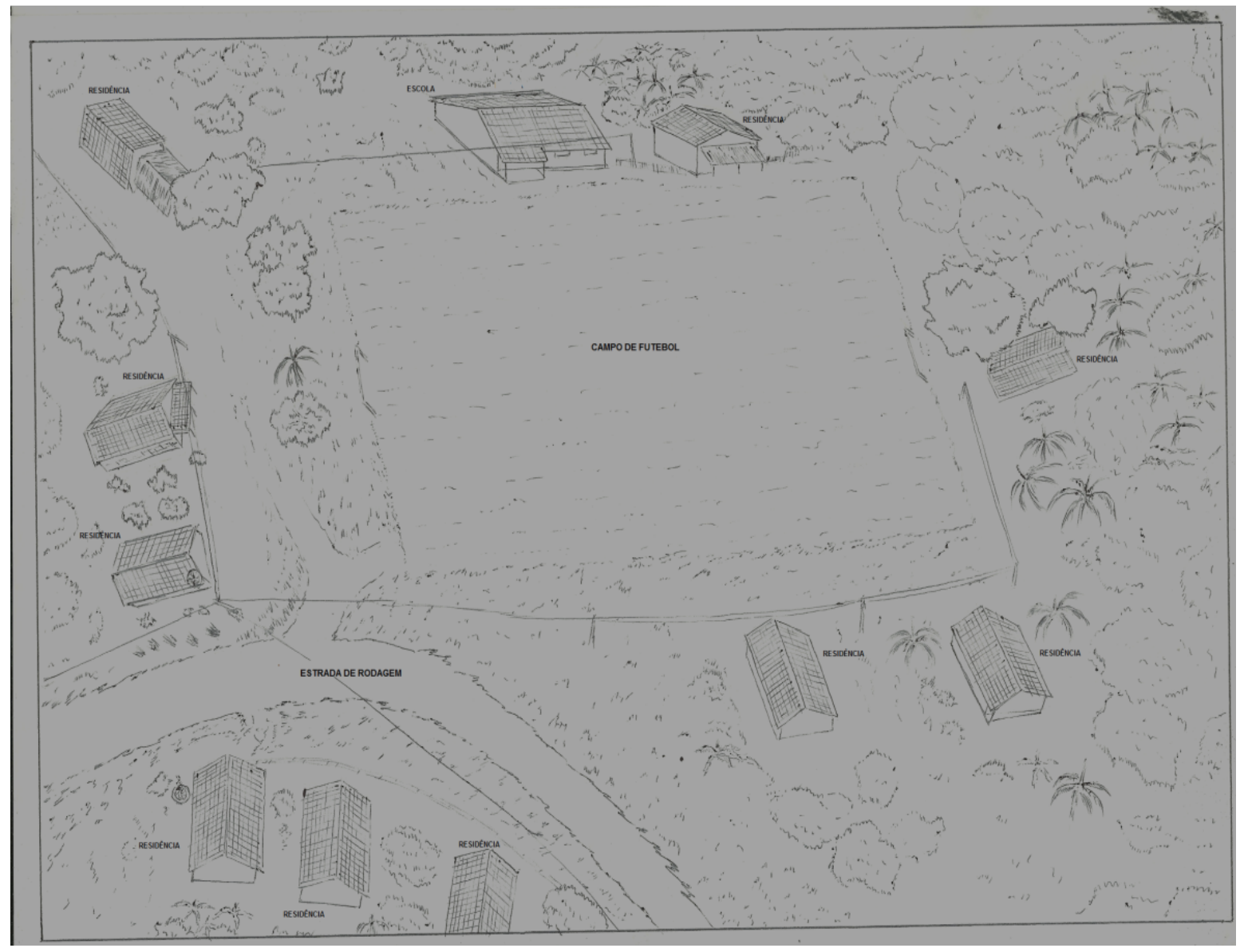

Em face aos argumentos acima apresentdos sobre a hipóstese de contato afroindígena da comunidade de Jurussaca, corroboro Oliveira et alii (no prelo) sobre se considerar Jurussaca uma comunidade afro-indígena (cf. capítulo 1, subseção 1.5).

Oliveira et alii (op. cit.) defendem o afro-indígena no contexto que inclui as variedades de português popular faladas no Brasil em comunidades rurais que conservam especificidades etnolinguísticas e que "se localizam" dentro de um continuum de variedades de português brasileiro [+marcadas], como o português afro-brasileiro e o indígena. Assumem que o afro-indígena detém características de língua "parcialmente reestruturada" com base em abordagens da morfossintaxe e em questões voltadas à morforfologia territorial da comunidade.

Assim, reafirmo a proposta do Continuum de Português, e que o português afrobrasileiro e o indígena compartilham com o locus das variedades [+ Marcadas], conforme a figura 2, seção 1.5. do capítulo 1, repetia abaixo: 


\section{O Continuum de Português Falado no Brasil}

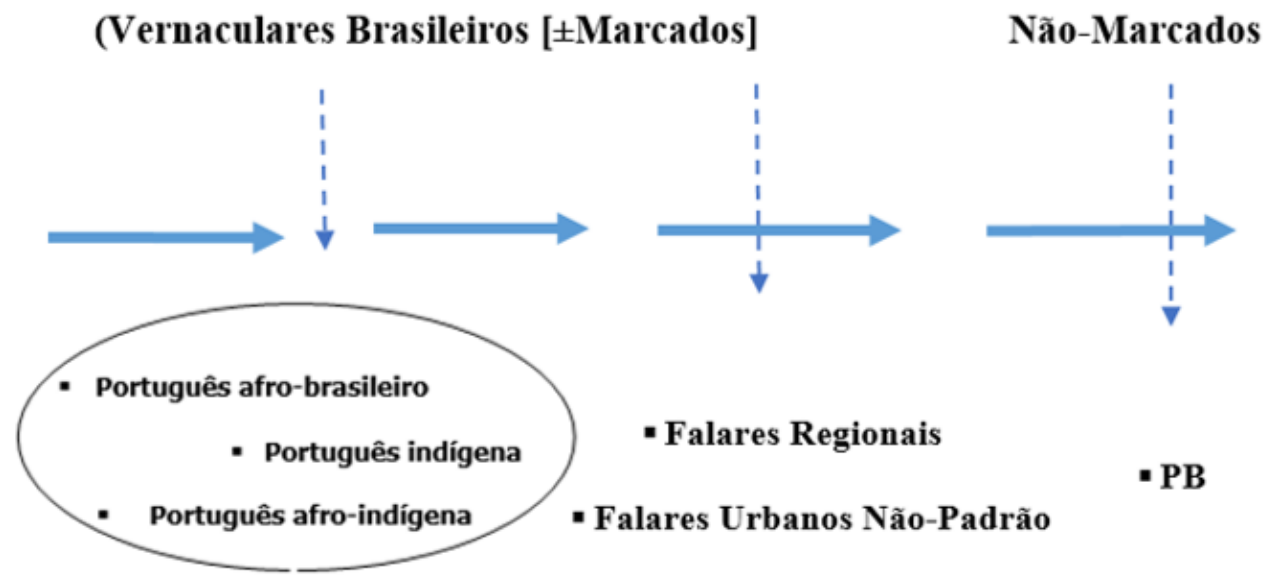

Como também argumentei no capítulo 1, reafirmo que nesta tese esse continuиm assume um papel de destaque não apenas pelas quetões já advogadas anteriormente, mas também para as análise do sistema pronominal de Jurussaca, se comparado a uma área vizinha - as cidades de Bragança e Tracuateua, pois a variedade afro-indígena [+marcada], ao ser comparada à variedade de Bragança/PA [-marcada], apresenta especificidades.

Logo, os estudos sobre PVB não definem essa variedade como uma unidade, mas como um conjunto de variedades, dialogando com o que aponta Pagotto (2007, p, 469) para as variedades populares - 'o conjunto de características comuns', citando anteriormente na subseção 1.4. do capítulo 1. Assim, um cotejo do sistema pronominal das variedades [+marcadas], contidas no círculo (à esquerda do continuum), certamente, evidenciaria um 'conjunto de características comuns', mencionadas por Pagotto - a ausência de pronomes clíticos acusativos e dativos de terceira pessoa pode ser tomada como um exemplo disso.

Por fim, em consonância às possíveis situações de contato por que passou a comunidade de Jurussaca, as especificidades presentes no Quadro 16, dos pronomes pessoais, que será apresentado mais adiante, não serão tomadas dentro de abordagens que apontam para casos de 'recategorização' pronominal. Isto é, a literatura brasileira vem tratando de casos de mudança no estatuto dos pronominais, a exemplo, o uso do pronome 'Ihe' como pro-forma de segunda pessoa, como caso de recategorização - a recategorização de lhe - em função de resultado de outros eventos, como o emprego de 'você' em lugar de tu, principalmente no sudeste. Em Jurussaca não apenas a pro-forma 'tu' tem alto índice de produtividade, como também a oposição 'tu' vs. 'você', correspondente aos contextos de informalidade $v s$. formalidade ou alternação relativamente ao grau de respeito é bastante 
produtivo. É nesse sentido que não defendo a recategorização de pro-formas pronominais como consequência de mudança por variação do uso, para as especificidades de Jurussaca. Defendo que as especificidades que ocorrem ali sejam tratadas como um processo mais complexo de 'reestruturação da gramática' em função do contato etnolinguístico e não de situações discursivas pontuais (Cf. Figueiredo \& Oliveira \&, 2013).

\subsection{Metodologia, construção e organização dos corpora da pesquisa}

Os corpora que compõem esta tese são fontes primárias de coleta de dados feitas por mim, no Pará: são gravações feitas na comunidade de Jurussaca, nos municípios vizinhos de Bragança e Tracuateua, e gravações de programas televisivos veiculados em Belém.

As primeiras gravações ocorreram já na minha primeira visita à comunidade em julho de 2010 e nas visitas seguintes, em dezembro de 2010, julho de 2011, dezembro de 2011, dezembro de 2012 e julho de 2012 e, ao todo, são cerca de 20 horas de gravação.

As gravações de áudio se deram em entrevistas feitas com várias famílias, nos vários momentos que estive na comunidade; na participação dos festejos, na entrega de presentes de natal em mais de uma ocasião (junto ao grupo de pesquisadores do projeto IPHAN/USP, em 2010) e também no natal dos anos de 2011 e 2012.

Após a gravação das entrevistas, passei à transcrição dos dados, seguindo a 'chave de transcrição’ do Projeto Vertentes (Lucchesi (2009(b)), seguindo o mesmo modelo de transcrição grafemática.

Passei à constituição de corpus específico, com sentenças selecionadas, com ocorrências pronominais. As construções pronominais do tipo "Ele nós deu..." demandavam uma análise fonológica. Para tal, contei com uma breve análise fonológia feita por Del Vigna (2014).

No Projeto se adotou a opção de recolha de amostras de fala na comunidade por meio de entrevistas (conduzidas pelos pesquisadores em campo) realizadas na casa dos informantes ou em lugares específicos da comunidade.

Parte dos dados a serem analisados são os mesmos que foram coletados no âmbito do projeto IPHAN/USP, hospedados no site do projeto. A outra parte, são gravações coletadas tanto em Jurussaca quanto nas cidades de Tracuateua e Bragança, nas várias visitas que fiz à região. 
Há, também, gravações de alguns programas televisivos de Belém, da 'mídia de massa' de caráter bastante popular, com depoimentos de pessoas nas delegacias, vítimas e/ou réus em delitos, dos quais extraio alguns exemplos para fins de cotejo com a variedade de Jurussaca.

\subsection{Análise dos corpora}

Nesta seção procuro descrever e analisar a sintaxe dos pronominais pessoais que ocorrem no português afro-indígena de Jurussaca (daqui em diante, PAfro-indJ), enfatizando os usos 'típicos' da comunidade, quanto às simetrias e/ou assimetrias que apresentam relativamente ao PB/PVB. Aliás as siglas $\mathrm{PB}$ e $\mathrm{PVB}$, sempre que utilizadas, são compreendidas como as variedades [não marcadas] e [+/ - marcadas], conforme o continnum de português.

No PAfro-indJ:

(i) o paradigma nominativo (eu, nós, a gente) ocorre conforme os usos já descritos para o PB/PVB, de modo geral, mas com certas especificidades;

(ii) os traços formal versus informal no paradigma de segunda pessoa;

(iii) os paradigmas acusativo e dativo, assim como o PB/PVB, apresentam os clíticos de $1^{\mathrm{a}}$. e $2^{\mathrm{a}}$. pessoas;

(iv) No paradigma dativo, na $3^{\mathrm{a}}$. pessoa, há ocorrência de objeto duplo em variação com o uso corrente do complemento oblíquo (em lugar do dativo prototípico, como ocorre na $1^{\mathrm{a}}$. e $2^{\mathrm{a}}$. pessoas);

(v) assim como o PB/PVB, os paradigmas acusativo e dativo, do PAfro-indJ, não possuem clíticos de $3^{\text {a }}$. pessoa, apenas PPs (contruções oblíquas);

(vi) a primeira pessoa do plural nós (nつs) acusativa/dativa, tem colocação clítica no PAfro-indJ (cf. $C l \mathrm{~V})$.

(vii) ocorrem as pro-formas pronominais esse um, essa uma, aquela uma, tal qual a pro-forma one, do inglês;

(viii) registra-se o uso de formas clíticas pronominais inerentes/afixais;

(ix) registra-se o uso de formas pronominais atemáticas que prononho se tratar de DPs reduplicados em orações paralelas do tipo parataxe cujo DP (deslocado) checará um traço do tipo EF. 
Procuro apresentar os dados separados pelos paradigmas de Casos: nominativo, acusativo e dativo/oblíquo, a fim de possibilitar uma visão mais geral das ocorrências, descritas no Quadro 10, seguindo a mesma distribuição em conformidade com as posições em que os pronominais se encontram nas colunas correspondentes aos respectivos Casos. (embora, como apresentarei, a expressão pronominal do PAfro-indJ foge a uma descrição prototípica de Caso).

\subsubsection{As primeiras análises}

Como já foi explorado no capítulo 2, as pro-formas pronominais têm status sintático bastante diferenciado e a primeira noção que define seu estatuto, trata-se do traço sintático-fonológico que as define como pronomes tônicos ou clíticos (XPs e $\mathrm{X}^{0} \mathrm{~s}$ ). Retomo algumas noções inicais dessas pro-formas, mencionadas anteriormente (capítulo 2, seção 2.4.4):

- As formas conhecidas tradicionalmente como pronomes são elementos que veiculam noções gramaticais (como os traços- $\varphi$ ), e sintático-semânticas (como a co-referência - relação que se estabelece entre duas expressões nominais usadas com valor referencial) e são muito diferentes entre si.

- No modelo minimalista (Chomsky, 1995, 1999b), as categorias pronominais tanto XPs quanto $\mathrm{X}^{0} \mathrm{~s}$ são elementos compostos por traços- $\varphi$. Os pronominais clíticos manifestam seus traços- $\varphi$ na sintaxe como categoria funcional (poderiam até ser considerados morfemas devido às suas características sintáticas e fonológicas - proposta de alguns autores, como Everett (1996)). Os itens lexicais - XPs - têm traços fortes e precisam ser verificados antes de Spell-out, já os itens $\mathrm{X}^{0} \mathrm{~s}$ têm seus traços fracos ${ }^{160}$ e são verificados depois de Spell-out, em LF.

Retomo, também, do capítulo 2, seção 2.4, as propriedades dos clíticos no PE, identificadas por Brito, Duarte \& Matos (2003, p. 835):

(i) apresentam potencial referencial ou predicativo;

160 Ver nota 80. 
(ii) têm a possibilidade de receber um papel temático;

(iii) a faculdade da referência específica ou arbitrária;

(iv) a capacidade de ocorrer em construções de redobro de clítico e de extração simultânea de clítico; ${ }^{161}$

(v) a faculdade de funcionar como um afixo capaz de alterar a estrutura argumental de um predicado.

Em função destas propriedades, os pronominais clíticos do PE são classificados na Gramática da Língua Portuguesa (Brito, Duarte \& Matos in Mateus et alii, 2003) e em outros trabalhos (D\&M, 2002 e D,M\&G, 2005) em cinco tipos tipologicamente distintos:

(vi) Clíticos com conteúdo argumental: os pronominais (não-reflexivos), os anafóricos (reflexivos e recíprocos) e o se-nominativo (Ex: trabalha-se demasiado).

(vii) Clítico argumental proposicional ou predicativo: o demonstrativo o (exemplo)

(viii) Clíticos quase-argumentais: o se-passivo (Ex. penduraram-se os quadros na parede) e os dativos ético e de posse (Ex. não me suje o tapete!/doem-me as costas).

(ix) Clítico com comportamento de afixo derivacional: os ergativos/anticausativos. (Ex.: derreteu-se o gelo)

(x) Clítico sem conteúdo semântico ou morfo-sintático: os clíticos inerentes (Ex.: Tu zangaste-te (Zangar-se)).

Os pressupostos que delineiam os padrões de colocação clítica no PE sinalizam uma diferença expressiva relativamente ao PB e funcionam como uma 'linha de corte' ao se comparar as duas variedades de português. O fato de o clítico poder ou não redobrar e poder ou não ser simultaneamente extraído (cf. nota 161) é, na verdade, o principal teste que as autoras utilizaram para propor uma tipologia clítica (para o PE).

161. A Extração Simultânea de Clíticos foi proposta inicialmente por Kayne (1975). Segundo Brito, Duarte, Matos (2003, p. 834) em PE, a extração simultânea clítica ocorre em frases coordenadas em que é possível que uma única instância do clítico recupere os argumentos a que está associado em cada um dos termos coordenados. São exemplos das autoras:

(31) (a) Ele tinha-o visto [-] e reconhecido [-] imediatamente.

(b) A Ana estava-lhe sempre a telefonar [-] para casa e a pedir conselhos [-]. 
Relativamente aos traços dos clíticos no PE, elencados acima, apresento as suas possibilidades no PB:

(i) o potencial referencial ou predicativo; ${ }^{162}$

(ii) a possibilidade de receber papel temático;

(iii) a possibilidade de modificar a grade argumental do verbo;

(iv) a faculdade de veicular referência específica ou arbitrária.

As característics tipológicas (viii) e (xix) do PE, acima, são inexistentes na gramática do PB:

- Clíticos quase-argumentais: o se-passivo (Ex. penduraram-se os quadros na parede) e os dativos ético e de posse (Ex. não $\boldsymbol{m e}$ suje o tapete!/doem-me as costas). ${ }^{163}$

- Clítico com comportamento de afixo derivacional: os ergativos/anticausativos. (Ex.: derreteu-se o gelo)

Como é sabido, a gramática do PB reanalisou essas formas, fazendo uso de construções indeterminadas e causativas/inacusativas, como:

(1) $[$ pro] penduraram o quadro

(2) o gelo derreteu

Outra característica que distingue PE e PB, também explorada nos capítulos 1 e 2, diz respeito à colocação clítica: no PB tanto na variedade padrão quanto não padrão, a próclise configura-se como a ordem não-marcada da cliticização (cf. capítulo 1, seção 1.2). No PAfro-indJ, a colocação clítica ( $1^{\mathrm{a}}$. e $2^{\mathrm{a}}$. pessoas), como é pressuposto, segue a colocação default do PB.

Outra variação entre PE e PB - o uso de pronomes lexicais como complementos: é agramatical em PE, marcada no PB, 'normal' no PVB e abundante no PAfro-indJ. Em se tratanto da $3^{\mathrm{a}}$. pessoa aliás, no PAfro-indJ esse uso é categórico e também recorrente na $1^{\mathrm{a}}$. e $2^{\mathrm{a}}$. pessoas, embora, em se tratando da $1^{\mathrm{a}}$.e $2^{\mathrm{a}}$. pessoas singular, ocorra mais construções com clíticos.

\footnotetext{
${ }^{162}$ Se consideramos a tese mais estrita de que o PB não possui mais clíticos de $3^{\mathrm{a}}$. pessoa em sua gramática, o potencial referencial ou predicativo também terá se perdido.

${ }^{163}$ Muitos dialetos do PB fazem uso de construções com o dativo ético, mas optam por construções como ‘minhas costas doem' em lugar da construção com dativo de posse do PE.
} 
(3) Eu vi ele ontem - PB/PVB/PAfro-indJ/*PE

A 'expressão pronominal' da comunidade de Jurussaca, representada nas tabelas abaixo, ilustra usos pronominais que se assemelham ao PB e ao PVB, de modo geral, mas que, também, distanciam-se dessas variedades quanto a usos regionais e certas 'inovações' atestadas ali. Para a análise dessas semelhanças/distinções tomarei como ponto de partida propostas anteriores já feitas para o Português Brasileiro por autores como Galves (2001a, b), Galves \& Abaurre (2002[1992]), entre outros.

Abaixo, seguem-se os Quadros 16 e 17 relativamente aos pronomes pessoais referenciais e às anáforas da expressão pronominal de Jurussaca, de modo geral. Em seguida passo às seções de análise dos tópicos selecionados.

\section{Quadro 16 - Pronomes Pessoais Referenciais de Jurussaca ${ }^{164} 165$}

\begin{tabular}{|c|c|c|c|}
\hline Pessoa & Sujeito & Complm. Direto & \begin{tabular}{|c|} 
Complm. \\
Indireto/Oblíquo \\
\end{tabular} \\
\hline $1^{\mathrm{a}} . \mathrm{sg}$. & eu & me & $\begin{array}{c}\text { me } \\
\text { pra mim } \\
\text { comigo }\end{array}$ \\
\hline $2^{\mathrm{a}} . \mathrm{sg}$ & $\begin{array}{c}\text { tu/ você/ cê } \\
\text { o(a) } \\
\text { senhor (a) }\end{array}$ & $\begin{array}{l}\text { você } \\
\text { te, lhe }\end{array}$ & $\begin{array}{c}\text { te, lhe } \\
\text { pra ti/ você, } \\
\text { contigo }\end{array}$ \\
\hline $3^{\mathrm{a}} . \mathrm{sg}$. & $\begin{array}{l}\text { ele/ ei, } \\
\text { ela }\end{array}$ & ele/ ela & $\begin{array}{l}\text { pra ele, ela } \\
\text { com ele/ela }\end{array}$ \\
\hline $1^{\mathrm{a}} \cdot \mathrm{pl}$ & nós, a gente & $\begin{array}{c}\text { *nós } \\
\text { nós } \\
\text { a gente }\end{array}$ & $\begin{array}{c}\text { *nós } \\
\text { pra nós/ a gente } \\
\text { com nós/a gente }\end{array}$ \\
\hline $2^{\mathrm{a}} \cdot \mathrm{pl}$ & vocês/cês & vocês & $\begin{array}{c}\text { pra vocês/cês } \\
\text { com vocês }\end{array}$ \\
\hline $3^{\mathrm{a}} \cdot \mathrm{pl}$ & $\begin{array}{l}\text { eles/ eis, } \\
\text { elas }\end{array}$ & $\begin{array}{l}\text { eles/ eis } \\
\text { elas }\end{array}$ & $\begin{array}{l}\text { pra eles/eis, elas } \\
\text { com eles/eis, elas }\end{array}$ \\
\hline
\end{tabular}

- O pronome complemento indireto *nós será tratado na subseção 3.4.8.

\footnotetext{
${ }^{164}$ Para a construção do quadro pronominal de Jurussaca, inspirei-me em Castilho (2010, p. 477) que insere, no quadro dos pronomes pessoais do $\mathrm{PB}$, tanto as formas de tratamento (formal) senhor (a), quanto as formas fracas dos pronomes (ocê, che ei, eis).

165 Além dos pronomes da tabela, ocorre com muita frequência em Jurussaca a expressão mano, que tanto funciona como Expressão- $R$ quanto como vocativo (um traço areal do Norte).
} 
- Além dos pronomes da tabela, a expressão mano, que tanto funciona como Expressão- $R$ quanto como vocativo, é bastante utilizada em Jurussaca (um traço areal do Norte).

Quadro 17 - As Anáforas na Expressão Pronominal de Jurussaca

\begin{tabular}{|c|c|c|}
\hline \multirow{2}{*}{ Pessoa } & \multicolumn{2}{|c|}{ Anáforas ligadas } \\
\cline { 2 - 3 } & clítica & tônica \\
\hline $1^{\text {a. }} . \mathrm{sg}$. & me & \\
\hline $2^{\text {a. }}$ sg. & te & \\
\hline $3^{\text {a }} \cdot \mathrm{sg}$. & se & \\
\hline $1^{\text {a. }} \cdot \mathrm{pl}$. & se & si \\
\hline $2^{\text {a }} \cdot \mathrm{pl}$. & se & \\
\hline $3^{\text {a }} \cdot \mathrm{pl}$. & se & si \\
\hline
\end{tabular}

3.4.2. O Paradigma Sujeito

\begin{tabular}{|c|c|}
\hline Pessoa & Sujeito \\
\hline $1^{\text {a. }}$ sg. & $\mathrm{eu}$ \\
\hline $2^{\mathrm{a}} \cdot \mathrm{sg}$. & $\begin{array}{c}\text { tu/você/ cê } \\
\text { o senhor, } \\
\text { a senhora }\end{array}$ \\
\hline $3^{\mathrm{a}} . \mathrm{sg}$. & $\begin{array}{c}\text { ele } / e i \text {, } \\
\text { ela }\end{array}$ \\
\hline $\mathbf{l}^{\mathrm{a}} \cdot \mathrm{pl}$. & nós, a gente \\
\hline $2^{\mathrm{a}} \cdot \mathrm{pl}$. & vocês/cês \\
\hline $3^{\mathrm{a}} \cdot \mathrm{pl}$. & $\begin{array}{c}\text { eles/ eis, } \\
\text { elas }\end{array}$ \\
\hline
\end{tabular}


- A Primeira Pessoa - eu, nós, a gente

Os pronomes pessoais de primeira pessoa eu e nós/a gente em Jurrussaca apresentam os usos similares aos do PB/PVB na função de sujeito.

O pronome em função acusativa - eu - consta no paradigma complemento Direto (cf. Quadro 16) porque em períodos compostos, nas construções causativas e perceptivas, normalmente, o sujeito da oração encaixada é o pronome eu em vez de me. No entanto, há duas possibilidades sintáticas de atribuição de Caso nessas orações: o verbo mais alto pode atribui Caso acusativo, tratando-se de Atribuição de Caso Excepcional (construção ECM) ou de construção de infinitivo pessoal, cujo verbo pode licenciar os pronomes nominativos, no caso, o pronome eu.

A forma pronominal eu é bastante utilizada em construções, que normalmente seriam do tipo ECM no PB, mas no PAfro-indJ são similares às de infinitivo pessoal. Ocorrem com verbos causativos e de percepção ${ }^{166}$, também similares às construções do PVB.

(4) ela mandou eu ir

(5) ela viu eu chegar

(6) a mamãe num deixou muito eu ficar lá... ai eu vim...

(7) ela botou eu pra estudar.

Assim como também são comuns as construções oblíquas para mim cujo verbo encaixado é 'processado' como infinitivo impessoal, em vez da construção tida como padrão, em que o verbo encaixado é analisado como infinitivo pessoal:

(8) ainda não deu pra mim arrumar assim....

(9) eu gosto de fazer assim.... eu pra mim fazer tudo... eu num faço não.....

Mas o uso mais corrente do pronome sujeito de primeira pessoa nas construções causativas e perceptivas é com o clítico me (tratarei na seção sobre o paradigma Complemento Direto). Essa, aliás, é uma das particularidades do PB que o distingue fortemente do PE, segundo Galves (2001a, p. 130), pois é comum em PB a ocorrência do pronome sujeito eu como sujeito de uma encaixada infinitiva em lugar do clítico me.

\footnotetext{
${ }^{166}$ Os verbos causativos e perceptivos (mandar, deixar, fazer, ver, sentir, ouvir etc), normalmente selecionam um complemento sentencial não-finito.
} 
(10) E por isso que vocês veem eu insistir tanto sobre issso (SSA-EF) ${ }^{167}$

- Nós / a gente

As formas da primeira pessoa do plural tanto ocorrem com uso definido quanto indefinido, utilizadas com referência arbitrária, principalmente a forma a gente. A variação que ocorre ente elas pode revelar mais sobre a sintaxe pronominal, relativamente à referência específica ou arbitrária do PAfro-indJ e ainda porque há contextos em que nós e a gente ocorrem em variação livre e outros em que nós é obrigatório: ${ }^{168}$

(i) Contextos em que nós/a gente ocorrem em variação livre:

(11) toda tarde tem novena a gente vai fazer novena toda tarde durante o mês todo dia... $($ a gente $=e u+n \tilde{a} o-e u)$

(12) tem algumas que a gente escolhe mesmo pra deixar pra cantar $($ g gente $=e u)$

(13) Eu comecei até ideia da Neta... aí o pessoal dizia não se for assim a gente num vai aceitar... (a gente $=e u+n \tilde{a} o-e u)$

(14) ...mas a gente só teve uma discussão e ela se afastou mesmo...(a gente $=$ eu+não-pessoa $\left(3^{a} \cdot\right.$ pessoa $)$.

(15) ...foi assim que a gente prestemu conta dos equipamento da casa de farinha que tá aí (a gente = eu+não eu +não pessoa $\left(3^{a}\right.$. pessoa) $)$.

(16) como é que nós vamo prestar conta de cinquenta mil... (nós = eu+não eu +não pessoa $\left(3^{a} \cdot\right.$ pessoa $\left.)\right)$.

(ii) contextos obrigatórios de nós (*a gente)

(17) a Umbelina... a minha prima Fátima e eu... nós três...

(18) ...porque eu tive um desentendimento, nós duas há uns dez anos atrás sobre esse trabalho de igreja sabe...

(19).... pois então vamo fazer nós dois junto né...

Em todos os exemplos de (17) a (19) a pro-forma nós tem referência necessariamente específica e, por esta razão, não pode ocorrer em variação com a gente ( \pm

${ }^{167}$ Exemplo retirado de Galves (2001a, p. 130, renumerado).

${ }^{168}$ Está fora do escopo deste trabalho fazer uma análise quantitativa desses usos no PAfro-indJ, mas um estudo nessa natureza poderia revelar mais sobre essas pro-formas 
arbitrário); por outro lado, os numerais (dois e três) requerem um traço [+pessoa] que não está em a gente.

- A Segunda Pessoa-tu, você, cêe

Como se pode ver no Quadro 16 as formas Completivas Diretas de segunda pessoa são tu, você, cê. No PAfro-indJ, os dados mostram que a oposição entre tu/você ainda se mantém (em muitos casos) em função da oposição formal/informal como a que se registra no uso do PE. Vale lembrar que não me refiro à perda da oposição tu/você explorada por Galves (2001a, p. 129-143), a qual a autora considera como fator fundamental para a mudança sintática operada no PB, responsável pela redução do paradigma verbal dessa língua de três pessoas gramaticais para duas, ou seja, não estou fazendo referência a Agree. Refiro-me apenas à oposição que ainda se registra quanto ao 'uso' dessas formas. O fator discursivo, relativamente às condições de produção dos textos, por exemplo, contribuiu para que os pronomes tu e ti aparecessem nas entrevistas apenas em contextos específicos.

No PB ou PVB, de modo geral, as marcas de formalidade são mais 'neutralizadas'. Em Jurussaca, elas são bem marcadas: as formas $t u$, $t i$, teu, tua nunca aparecem, por exemplo, quando falam comigo (apesar das minhas tentativas de criar contextos de informalidade). Vê-se que o uso das formas $t u$, $t i$, teu, tua ocorrem sempre entre eles: (nos dados do IPHAN/USP, por exemplo, aparecem nos discuros indiretos). Um exemplo disso pode ser dado a partir do seguinte contexto: durante uma gravação na casa do senhor Valdecir, sua esposa dirige-lhe uma pergunta/questionamento:

(20) "tu num disse que tu num ia trabalhar amanhã?"

Ou em discursos indiretos, casos em que a existência da oposição formal vs. informal fica clara, pois os informantes, ao contar/relatar um fato que aconteceu entre eles usam, normalmente, o pronome tu:

(21) ele disse por que tu num qué estudá?

(22) aí eu disse, olha tal dia tem reunião do conselho é bom tu aparecer lá

(23) aí eu fiquei esperto eu digo tu tá me enrolando... num vou te dar...

(24) aí ele ficou até com raiva... pô Genilson... eu num sei o que tem... eu te ligo e tu num atende... 
(25) aí eu dei. [Ø] [Ø]... fui dando de pouco a pouco... dei a Xerox do título né... aí ele disse eu quero teu documento que é pra gente ir começando o projeto

(26) eu digo rapaz problema teu... quer passar lá por cima dos cara passa...

O mesmo ocorre com o emprego de lhe em uso formal como pronome de tratamento (cf. Galves, 2001a p. 140) que será tratado na seção dos paradigmas acusativo/dativo.

Um reforço sobre o argumento da oposição formal vs. informal na comunidade, como mencionei anteriormente, quando as pessoas de lá referiam-se a mim (pesquisador) ou à pessoa que estava comigo eram situações em que eles sempre utilizavam, preferencialmente, as formas de tratamento senhor (com as variações morfo-fonológicas: senhô/sinhô/nhô) (principalmente as pessoas mais idosas) ou, então, o pronome de segunda pessoa você:

(27) O sinhô podia deixar essa casa aberta aqui, assim como o sinhô deixava ucê achava quando chegássemos mas agora não, se o sinhô vai na casa do vizinho dexô a porta aberta, quando chegar já o que tinha por aí, já levaru tudo.

Outras vezes a forma utilizada para se dirigir a mim (pesquisador) era 'professor':

(28) Porque cada ano mudifica o estudo, né professor?

Para além das formas mencionadas, em certa ocasião, em uma das muitas vezes em que estive na comunidade, em uma situação de descontração, a informante, demonstrando constrangimento porque a sua cadeira estava quebrada, utilizou a 'expressão' mano para se referir a uma das pessoas que estavam comigo, meu sobrinho, um jovem de 15 anos, que estava filmando enquanto eu iniciava uma conversa com a pessoa em pauta:

(29) vai filmar minha cadeira, mano... mas meu Deus ele vai filmar a minha cadeira, mano (risos)

Neste exemplo, a expressão mano, é utilizada como vocativo e pode estar ocorrendo em oposição ao pronome de tratamento formal/respeitoso senhor. Note que a expressão foi utilizada referindo-se a um adolescente, em um indício de que ali se opera o traço de oposição formal versus informal presente também no par tu/você. 
Sobre a expressão mano também é interessante observar que ela funciona tanto como vocativo, quanto como Expressão-R.

Nas cidades de Bragança e Tracauteua não se verifica a oposição formal versus informal, conforme se pode verificar em uma conversa com um comerciante de Bragança que utiliza tanto os pronomes 'tu' quanto 'você' em contexto de variação:

(30) a. Aí tu vê tanta gente, diz assim rapaz aqui é um movimento...

b. Se você for agora lá na feira você vê gente vê carro aquele movimento todo...

O dado (30), coletado em Bragança com um comerciante de cerca de 60 anos e nativo da cidade, nos aponta um fato muito significativo, se cotejado com a oposição 'tu/você' que descrevi acima, no Pafro-indJ. O exemplo (30) atesta que, na cidade de Bragança, há cerca de 40 minutos da comunidade, as marcas de formalidade são neutralizadas. Portanto, Bragança é um bom exemplo da perda da oposição formal vs informal em variedades [-marcadas], se comparada com o português de Jurrussaca [+Marcado], um traço que ratifica o contínuum de português, repetido na subseção 3.2.2.

- Aforma fraca cêêcê:

(31) cês querium falar com o Valdeci né?

Sobre as formas fracas cê, cês, retomando o capítulo 2, seção 2.5. "Sobre a existência de pronome fraco no $P B$ ”, em que fiz referência à tipologia pronominal que contempla os pronomes fracos como pro-formas 'independentes' (cf. Cardinaletti \& Starke, 1999). As formas do continuum ratificam essa tipologia:

- Uso da pro-forma você/cêe 'arbitrário'

(32) a pessoa tendo fé... porque o que importa hoje é fé, se cê não sente fé, num adianta nada.

(33) porque cê... cê... só roçá o mato... aí você queima... aí pode prantá... aí cê só vai lá pra colhê... 
(34) olha... você vai ter esse pedaço aqui é seu... aqui ninguém num mexe... aqui eh você vai se você tiver os seus filho, se você tiver a... construir a sua família, os seus filho vão trabalhá aqui com vo... contigo aqui dentro desse pedaço.

- A Terceira Pessoa-ele, ei, ela, eles, eis, elas

As pro-formas pronominais ele(s) / ela(s) e, também, as formas fracas masculinas ei, eis são as licenciadas Pafro-indJ para a terceira pessoa nominativa. O Pafro-indJ também licencia o se nominativo (retomo a forma se mais adiante, na subseção 3.4.7.2.)

(35) ...é por isso que eis queria muntar em cima de nóis...

- O pronome ele/ela nas construções Tópico/sujeito e Construções relativas

As construções tópico/sujeito (cf. GALVES, 2001; ARAÚJO, 2009) largamente atestadas no PB/PVB, também são comuns no PAfro-indJ:

(36) [essa casa de farinha $]_{i}$ ela $\mathbf{a}_{i} .$. foi feito o projeto só os equipamento...

(37) eu lembro que [a minha irmã $]_{i}$ ela $a_{i}$ começou trabalhar de professora...

(38) [mas os professores $]_{i}$ eles $_{i}$ num são muito ativo...num incentivum as criança.... aqui tem muita criança essa comunidade.

Alé da relação tópico/sujeito, evidenciada nos exemplos (36) a (38), ns construções relativas PAfro-indJ, é muito recorrente o uso de pronomes lembrete ou resumptivos (TARALLO, 1993; KATO, M, 1993; NUNES, J., 2009):

(39) ....cas menina as filhas $d[0 \text { meu primo }]_{i}$ ali que ele i $_{i}$ tem... uma cinco menina assim grandinha

(40) porque lá na casa tem [outras pessoas] $]_{i}$ que eles $_{i}$ já dizem de outro jeito

(41) a Suely [uma colega $]_{i}$ que eu tenho ali que ela $\mathrm{a}_{\mathrm{i} . . .}$

(42) é porque [a menina $]_{i}$ que ela $\mathbf{a}_{\mathrm{i}}$ é a presidente do Clube de Jovem...

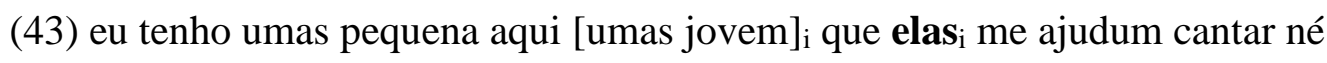

(44) [a Belica minha irmã $]_{i}$ que ela ${ }_{i}$ é professora disse tu ensinou as menina assim... 


\begin{tabular}{|c|c|}
\hline Pessoa & Compl. Direto \\
\hline $1^{\mathrm{a}} \mathrm{sg}$. & me \\
\hline $2^{\mathrm{a}} \cdot \mathrm{sg}$. & te/tu, lhe \\
\hline $3^{\mathrm{a}} \cdot \mathrm{sg}$. & $\begin{array}{c}\text { ele/ei, ela } \\
\text { se, si }\end{array}$ \\
\hline $1^{\mathrm{a}} \cdot \mathrm{pl}$. & \begin{tabular}{c} 
*ós, nós, $^{\text {a gente }}$ \\
\hline $2^{\mathrm{a}} \cdot \mathrm{pl}$.
\end{tabular} \\
\hline $\begin{array}{c}\text { vocês/ } \\
\text { cês }\end{array}$ \\
\hline $3^{\mathrm{a}} \cdot \mathrm{pl}$. & $\begin{array}{c}\text { eles/eis elas, } \\
\text { se, si }\end{array}$ \\
\hline
\end{tabular}

*o pronome de $1^{\text {a }}$. ps. do plural 'nós' ['nつs] ocorre preposto a verbos transitivos e bitransitivos (Ele nós ajudou / Ele nós deu). Ao lado desse pronome também ocorre o pronome 'nós' em posposição ao verbo (ele ajudou nós). Na subseção 3.4.8, defendo que se trata da mesma forma homófona, porém com funções distintas: um item pronominal clítico, quando preposto ao verbo e fraco quando posposto (cf. Galves, 2001 - ver cap 1, subseção 2.5). Tratando-se de uma inovação da expressão pronominal de Jurussaca.

- A primeira pessoa-me, eu

Galves \& Abaurre (2002 [1992]) em análise de dados do Projeto NURC, observam que, no português brasileiro, na primeira (e na segunda) pessoa do singular, relativamente aos pronomes clíticos, não ocorrem muitas mudanças, isto é os clíticos de $1^{\mathrm{a}}$. pessoa me e te continuam a ser usados normalmente como complementos em função acusativa e dativa. Salvo alguns usos regionais ou o uso mais disseminado no PVB, que registra as ocorrências dos pronomes $e u$, tu como complementos diretos, o PB (culto) usa normalmente os complementos clíticos.

Em Jurussaca, a primeira pessoa apresenta o paradigma do PB. A variação comum ao PVB, com o pronome nominativo - eu - não foi encontrada em orações simples (com um só verbo).

(45) Ele me agradece sim 
(46) eu tenho que me dar um trato...

Nas construções com locuções verbais do tipo causativas ou perceptauais normalmente ocorre o pronome tônico eu como complemento direto ou acusativo, casos já discutidos anteriormente na subseção 'paradigma nominativo', conforme os exemplos (47) a (49), repetidos:

(47) ela mandou eu ir

(48) ela viu eu chegar

(49) ela botou eu pra estudar.

- A primeira pessoa-plural - *nos, nós, a gente

A forma referencial clítica acusativa - nos - licenciada no português [não marcado], não ocorre no PVB. Nesta variedade são licenciadas as formas nós/a gente. Já no PAfro-indJ esse quadro é ainda mais enriquecido com a forma *nós [nวs/nつis] com colocação pré-verbal e em variação com as pro-formas nós e a gente (as construções com *nós serão discutidas na subseção 3.4.8).

(50) eles viru nós lá

(51) sempre eles falam que a prefeitura já roubou nós aqui que só a porra...

- A segunda pessoa - te, lhe, vocês

Os clíticos acusativos de $2^{\mathrm{a}}$. pessoa do singular - te, lhe - são utilizados no PAfroindJ com distinção quanto ao critério formalidade e respeito (cf. já discutido na subseção dedicada ao paradigma nominativo: A Segunda Pessoa - tu, você, cê, mano). Nos discursos indiretos, normalmente aparece a forma te (e lhe quando se trata de diálogo entre pessoas de faixa etária diferente ou quando se trata de complemento dativo). Nos diálogos entre pesquisador e informante, sempre aparece a forma lhe.

(52) ela dizia vai-te embora fulano, cria vergonha nessa cara, tá virando bicho

(53) eu lhe juro que é (lhe dativo - diálogo entre informante e pesquisador) 
(54) eu disse ah não não sabia ele disse é eu lhe juro que é (lhe dativo e discurso indireto: conta uma conversa entre uma senhora da comunidade e um vendedor/visitante).

(55) (...) levum tudo às vezes o que o senhor tem lhe matam por nada (diálogo entre informante e pesquisador)

(56) (...) essa que eu tô lhe dizendo que é sogra dela da Maria José (diálogo entre informante e pesquisador)

(57) "eu num vô lhe cortar... num vô lhe cortar porque cê é minha vó" (diálogo entre avó e neta- discurso indireto)

Chamo a atenção para o traço formal te/lhe que ocorre na comunidade. Um forte traço que opõe a forma [+marcada] Pafro-indJ e os falares urbanos [- marcados]. Os exemplos (53), (53) e (56) são complementos indiretos e poderiam ser preenchidos pelo clítico dativo de segunda pessoa - te - no entanto, em função do traço [+formal] ocorrem normalmente com o clítico lhe.

- Aforma vocês

Em se tratando da $2^{\mathrm{a}}$. pessoa do plural - vocês - o paradigma acusativo do PAfroindJ é similar ao do PB/PVB.

(58) eu vi vocês ontem

- A terceira pessoa-ele, ela

A $3^{\text {a }}$. pessoa no PAfro-indJ ocorre tal qual o $\mathrm{PB} / \mathrm{PVB}$, sem clíticos.

(59) pra num deixar eles ficarem também por aí à toa

(60) não, no dia é que eu pego eles

(61) a gente colhia ele [o café] colocava no sol, deixava secar ele bem sequinho, quando fosse pa torar a gente agarrava esquentava ele, tirava aquela casca e agarrava ia torrar ele. 


\subsubsection{Paradigma Complemento Indireto}

\begin{tabular}{|c|c|}
\hline Pessoa & Compl. Indireto \\
\hline $1^{\mathrm{a}} \mathrm{sg}$. & me \\
\hline $2^{\mathrm{a}} \cdot \mathrm{sg}$. & te, lhe \\
\hline $3^{\mathrm{a}} \cdot \mathrm{sg}$. & $($ objeto duplo) \\
\hline $1^{\mathrm{a}} \cdot \mathrm{pl}$. & $*^{\prime}$ nós \\
\hline $2^{\mathrm{a}} \cdot \mathrm{pl}$. & - \\
\hline $3^{\mathrm{a}} \cdot \mathrm{pl}$. & $($ objeto duplo) \\
\hline
\end{tabular}

Nesta subseção, sobre o paradigma Complemento Indireto, optei por mencioná-lo separadamente do paradigma oblíquo, dadas as distinções sintático-semânticas entre eles. Em se tratando de pronominais a literatura, normalmente, trata os DPs complementos, [+animados] como objetos indiretos - o dativo prototípico - e encabeçados pelas preposições a e para. Já os [-animados], inroduzidos pelas preposiçoes $a$, para, de, em etc. são tratados como complementos relativos e/ou circunstanciais (cf. Bechara, 2009; Rocha Lima, 2007).

- A primeira pessoa-me, *nós

(62) eu tenho que me dar um trato

(63) eles nóis doaru mil reais (ver subseção 3.4.8)

O uso do dativo na primeira pessoa no PAfro-indJ - me - ocorre em variação com a forma oblíqua (ver complemento oblíquo na próxima subseção), o que não apresenta diferenças em relação ao PB, de modo geral:

- A segunda pessoa - te, lhe

(64) ele dizia "não, eu vou te dar"

(65) a minha mãe era bonita vou lhe falar! 
(66) essa que eu tou lhe dizendo que é a sogra dela da Maria José.

(67) é o mais antigo ... ele aí se for aí ele vai lhe expricá tudinho.

Assim como na $1^{\mathrm{a}}$. pessoa, o uso do dativo na $2^{\mathrm{a}}$. no PAfro-indJ ocorre também em variação com a forma oblíqua - te/pra você.

$\mathrm{Na}$ segunda pessoa não ocorrem os clíticos dativos $o(s),(a) s$,

- A terceira pessoa -lhe(s)

Cecim (2014, quadro 14, p. 145), analisando gêneros discursivos da escrita, encontra os clíticos dativos neles, como os gêneros ligados às esferas Institução e Escola: a ata e a redação. Os clíticos lhes, lhes, prototípicos de $3^{\mathrm{a}}$. pessoa têm sido discutidos na literatura como um caso de desaparecimento da gramática do PB (cf. Galves, 2001; Torres Morais \& Berlinck, 2006), entre outros. A estratégia do PB é a construção oblíqua: a/para ele, a/para ela. A utilização dos pronomes em gêneros da escrita apenas ratificam que eles não fazem parte da gramática, mas são adquiridos tardiamente e são utilizados apenas nesses registros.

\section{- Objeto duplo}

Tem sido descrita a existência de objetos duplos em algumas variedades [marcadas] e [+marcadas] do continuum, principalmente em comunidades afro-brasileiras (LUCCHESI \& MELLO, 2009), assim como no PVB do Rio de Janeiro (GOMES, 2003a).

(68) ele vendia compade Jacó porco gordo. ${ }^{169}$

No PAfro-indJ, relativamente à terceira pessoa, ocorrem também as construções de objeto duplo descritas na literatura, mas com uso pouco frequente:

(69) Ela sabe aí a história... Eles pediru um porco um hômi e ele negô o porco...

${ }^{169}$ Exemplo retirado de Lucchesi \& Mello (2009, p. 169, renumerado). 
Essas construções são casos muito interessantes de licenciamento de complementos do tipo objetos indiretos (complemento relativo ou oblíquo, conforme são tratados pela tradição gramatical) sem a preposição. São comuns nas línguas crioulas do atlântico (cf. Lucchesi \& Mello, 2009).

No entanto, até o presente momento foi encontrada apenas a ocorrência (69) relativamente ao objeto duplo, com o SN lexical, com papel temático Fonte, sem preposição. Por se tratar de apenas uma ocorrência, tratarei esse dado como marginal.

\subsubsection{Paradigma Oblíquo}

\begin{tabular}{|c|c|}
\hline Pessoa & Oblíquo \\
\hline $1^{\mathrm{a}} \mathrm{sg}$. & $\begin{array}{c}\text { pra mim } \\
\text { comigo }\end{array}$ \\
\hline $2^{\mathrm{a}} \cdot \mathrm{sg}$. & $\begin{array}{c}\text { pra ti /tu/ você } \\
\text { contigo }\end{array}$ \\
\hline $3^{\mathrm{a}} \cdot \mathrm{sg}$. & $\begin{array}{c}\text { pra ele/ei, ela } \\
\text { com ele/ ela }\end{array}$ \\
\hline $1^{\mathrm{a}} \cdot \mathrm{pl}$. & $\begin{array}{c}\text { pra nós/a gente } \\
\text { com nós/ a gente }\end{array}$ \\
\hline $2^{\mathrm{a}} \cdot \mathrm{pl}$. & $\begin{array}{c}\text { pra vocês/cês } \\
\text { com vocês }\end{array}$ \\
\hline $3^{\mathrm{a}} \cdot \mathrm{pl}$. & $\begin{array}{c}\text { pra eles/eis, elas } \\
\text { com eles/elas }\end{array}$ \\
\hline
\end{tabular}

- A primeira pessoa - pra mim, comigo, pra nós, pr’a gente, com nós, com a gente (c'agente)

(70) porque num mandaram mais ofícios pra mim não

(71) não, inda num veio ainda com nós aqui

(72) eles vieru, participaru só duma reunião aqui com nós

(73) ele sempre dizia Valdeci, volta lá com a gente

(74) a gente sempre conversamos em reunião isso, os pessoal dizem pr'a gente, olha... 
O PB, de modo geral, também opta pela construção oblíqua: para mim em vez da clítica acusativa me. O exemplo abaixo, de Torres Morais \& Berlinck (2006) é uma argumento a esse favor: ${ }^{170}$

(75) O Kumon dá um belo apoio para nós, orientadoras, o material é programado e de excelente qualidade e estamos sempre nos reciclando. (Cláudia, 02/1997).

- A segunda pessoa - pra ti, pra tu, pra você(s), contigo, com tu, com você(s)

(76) aí eu disse não meu documento tá pra Bragança... bora marcar outro dia que eu levo pra ti e ele agoniado...

(77) é...descobriram porque se dissesse assim: "Olha, de manhã venha buscar tal coisa pra ti’...

(78) eu vou dizer só aqui pra vocês

(79) olha... você vai tê... esse pedaço aqui é seu... aqui ninguém num mexe... se você tivé os seus filho, se você tivé a... construir a sua família, os seus filho vão trabalhá aqui contigo aqui dentro desse pedaço

- A terceira pessoa - pra ele(a), pra eles(as), com ele(a), com eles(as)

(80) mas eu falo pra elas falarem assim...

(81) só que eu peço pras mulher daqui da comunidade pra elas me ajudarem né...

(82) por isso que eu sempre pulo fora fico igual só mesmo papagaio só escutando o que eles querem e num dou $[\varnothing]$ pra eles

\subsubsection{As Anáforas}

Como já foi amplamente discutido no capítulo 2, seção 2.3.2, a noção de anáfora não é uniforme: De modo geral, corresponde ao processo que consiste em utilizar uma forma linguística ou um vazio para remeter a um antecedente. A Teoria Gramatical, na perspectiva sintática, com base na noção de c-comando restringiu o termo anáfora aos elementos localmente ligados ao seu antecedente e referencialmente dependentes, passando a tratar

${ }^{170}$ Exemplo retirado de Torres Morais \& Berlinck (2006, p. 22), dado renumerado. 
distintamente as anáforas dos pronomes por conta da natureza referencial da forma anafórica, ficando, o termo restrito aos elementos pronominais reflexivos e recíprocos.

Assim, as anáforas, distinguem-se dos pronomes por suas propriedades referenciais fortemente dependentes que precisam estar ancoradas dentro da oração e ligadas localmente ao seu referente, em consonância ao Princípio A da Teoria de Ligação: uma anáfora tem de estar ligada no domínio local ou domínio mínimo.

Como foi mencionado no capítulo 2, o pronome se em língua portuguesa tem tradicionalmente uma gama de possibilidades: funciona como anáfora ligada, indeterminador do sujeito (se-nominativo), agente da passiva (ou se-acusativo, para as análises que consideram a passiva sintética), pronome 'reflexivo inerente' de certos $\operatorname{verbos}^{171}$.

O teste relativamente à impossibilidade da paráfrase com a si próprio / mesmo mostra quando se trata de anáforas ligadas ou clítico inerentes ou reflexivos inerentes (pseudo-reflexivos). Segundo Brito, Duarte e Matos (2003, p. 808) esta é uma propriedade lexical dos próprios verbos, uma especificidade das línguas românicas e do português em particular. Tais verbos, normalmente, são de experiência física e psicológica (lembrar-se, indignar-se) e selecionam um papel temático Experienciador para argumento externo, e Tema/causa para o argumento interno oblíquo.

Abaixo, repito o Quadro 17, referente às anáforas, apresentado acima, no início da seção.

\section{Quadro 17 - As Anáforas Ligadas na Expressão Pronominal de Jurussaca}

\begin{tabular}{|c|c|c|}
\hline \multirow{2}{*}{ Pessoa } & \multicolumn{2}{|c|}{ Anáforas ligadas } \\
\hline & clítica & tônica \\
\hline $1^{\text {a }}$.sg. & me & \\
\hline $2^{\text {a }}$.sg. & $\begin{array}{c}\text { te } \\
\text { se }\end{array}$ & \\
\hline $3^{\text {a }}$. sg. & se & si \\
\hline $1^{\text {a }}$.pl. & se & \\
\hline $2^{\text {a }}$.pl. & se & \\
\hline $3^{\text {a }}$.pl. & se & si \\
\hline
\end{tabular}

${ }^{171}$ Para Otero (1999) o comportamento de verbos+se permite levantar a hipótese de que o papel dos "reflexivos inerentes" ou "pseudo-reflexivos" é serem "destransitivadores". 
Como se pode verificar no quadro 17 as formas das anáforas ligadas do PAfro-indJ distingue apenas a primeira me pessoa das demais se. Na segunda pessoa te e se ocorrem em variação. Esse uso, aliás, assemelha-se ao uso que se faz nas demais variedades [+marcadas] de português brasileiro.

(83) a. nós se ajuntava aqui oh...que nem agora ... a...daqui de casa da...da... daquela outra casa daquela daqui em diante daí juntava tudinho e ia embora.

b. Já se sentimu...

\subsubsection{O estatuto dos pronomes atemáticos elou inerentes}

\subsubsection{O clítico inerente se}

Ao lado da anáfora ligada se, o clítico inerente se liga-se aos verbos descritos como pronominais. O clítico inerente é muito comum na região norte, inclusive em construções que em PB não são comuns, como (84), comum em Belém:

(84) eu me acordei cedo

Em jurussaca, as construções com o clítico inerente são também muito comuns. As sentenças (85) e (86) atestam um exemplo de emprego duplo de se: como anáfora ligada e como clítico inerente:

(85) era pai... aí se ajuntou-se a filha do irmão com o tio... ai tem um... uma geração muito grande [né]...

(86) ele é daqui, ela nasceu e se criou-se aqui

(87) eu vejo que eles num se interessum muito...

(88) do Maranhão esses um se escaparu pra cá

(89) aí o bichão foi passando aí foi s'imbora num sei pr'onde ele foi pra cá

(90) Mas ele criou-se aí c'avó

(91) ela se interessava bem pela comunidade

(92) o fogo derrubô todinho, cabou-se o açaizá que tinha... 
Para uma proposta de análise desses construções, retomo a proposta de Bonet (1991), discutida no capítulo 2 (seção 2.4.3.1.) sobre o clítico ético, pois, "Ethicals never play a syntactic role" (op. cit. p. 63) e, para Bonet, eles parecem estar mais ligados ao discurso:

Contrary to Borer \& Grodzynsky (1986) I do not assume that the insertion of ethicals is a lexical process (they do not have any effect on the syntax, and they do not alter the argument structure of the verb or anything else related to it). These clitics seem to be mainly discourse-related. In any case they are very different from other uses of clitics presented earlier ${ }^{172}$.

(BONET, 1991, p. 64)

Os exemplos de clítico inerente em (85) e (86) assimilam-se aos casos de clítico ético, nos termos de Bonet (op. cit, p. 64): em que clíticos éticos estariam mais relacionados a questões discursivas do que sintáticas.

Assim, as ocorrências acima poderiam ser tratadas, sintaticamente, como um caso de geração na base. A título de exemplo, apresento a representação proposta de Geração na Base de Borer (1981), citada no capítulo 2, seção 2.4.3:

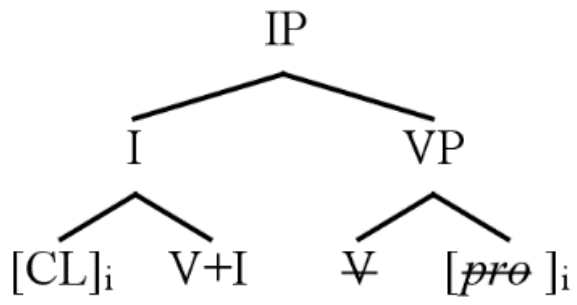

A geração na base, como já mencionado, permite explicar por que clíticos éticos e/ou inerentes não fazem referência a nenhum argumento temático.

É possível hipotetizar que ele tem comportamento similar ao de um morfema (pronomes clíticos seriam similares a afixos ou morfemas de concordância), apesar de estar sintaticamente coindexados a uma categoria pro em V (87), repetido abaixo:

\footnotetext{
172 Tradução aproximada: “Ao contrário de Borer \& Grodzynsky (1986) eu não assumo que a inserção de éticos seja um processo lexical (eles não têm qualquer efeito sobre a sintaxe, e eles não alteram a estrutura argumental do verbo ou qualquer outra coisa relacionada a ele). Estes clíticos parecem estar relacionados ao discurso. Em qualquer caso, eles são muito diferentes de outros usos de clíticos mencionados anteriormente"
} 
(93) eu vejo que [eles num se interessum muito...]

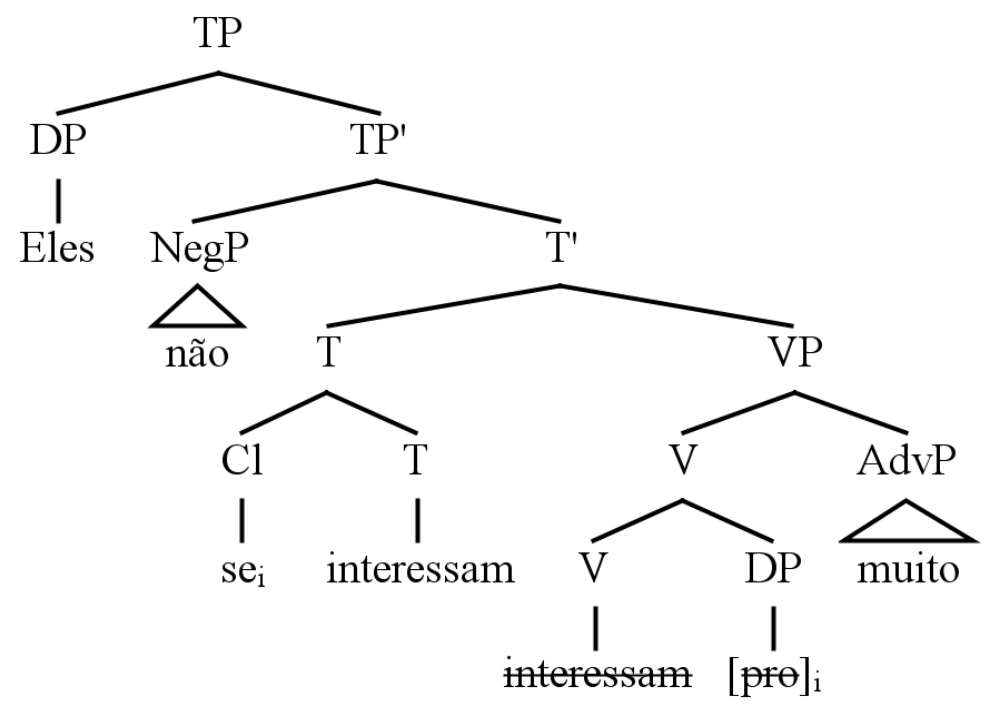

\subsubsection{O clítico sujeito}

O clítico se como vem sendo atestado, tanto ocorre como anáfora (default) (cf.(83), acima), e também em construções nas quais é atemático. Nas sentenças (87) a (92), no entanto, o clítico ocorre em função nominativa, pouco utilizada no português brasileiro.

(94) é só um pedaço, pôca terra pá se trabalhar, [num tem terra pá se trabalhar]

(95) ah, se plantava tudo era maniva era arroz, era feijão, era tabaco... tudo se plantava

\subsubsection{O estatuto morfossintático do pronome lhe em construções atemáticas}

Há uma vasta literatura que discute o estatuto sintático de lhe no PB (Torres Morais \& Berlinck (2006, 2007), Figueiredo e Silva (2010)=, entre muitos outros. Esses estudos, de modo geral, atestam o desparecimento de lhe de terceira pessoa na oralidade ${ }^{173}$.

Em construções como em (96) o pronome lhe é atemático, parece estar amalgamado ao verbo.

${ }^{173}$ A froma lhe de $3^{\mathrm{a}}$. pessoa, na escrita mais formal, continua sendo produtiva no PB, conforme atestam Torres Morais \& Berlinck (2006, nota 16): "Segundo os veterinários, restava-lhe, no máximo um mês de vida. (Veja, 06/10/00)". 
(96) ...ele já ia e insurtava o pessoal que passavam no gapó... deu-lhe numa senhora pra lá.... deu-lhe noutra derramou o açaí duma mulher por lá...

É importante salientar que essas construções não são exclusivas do PAfro-indJ, a exemplo de (97), da variedade [+ marcada] de Belém.

(97) foi uma briga que ele estava deitado lá no sofá, entendeu... aonde o padrasto chegou e deu-lhe uma garrafada em seu rosto, entendeu... e vieru vias de fato... (Programa Barra Pesada - Belém)

Ao lado das construções atemáticas com lhe no PAfro-indJ também ocorrem construções imperativas atemáticas como (97), com te:

(98) Vai-te embora fulano cria vergonha nessa cara tá virando bicho ruim

A projeção estrutural de sentenças como (96) e (98), seriam do tipo (99):

(99) Ela podia dá-lhe nele

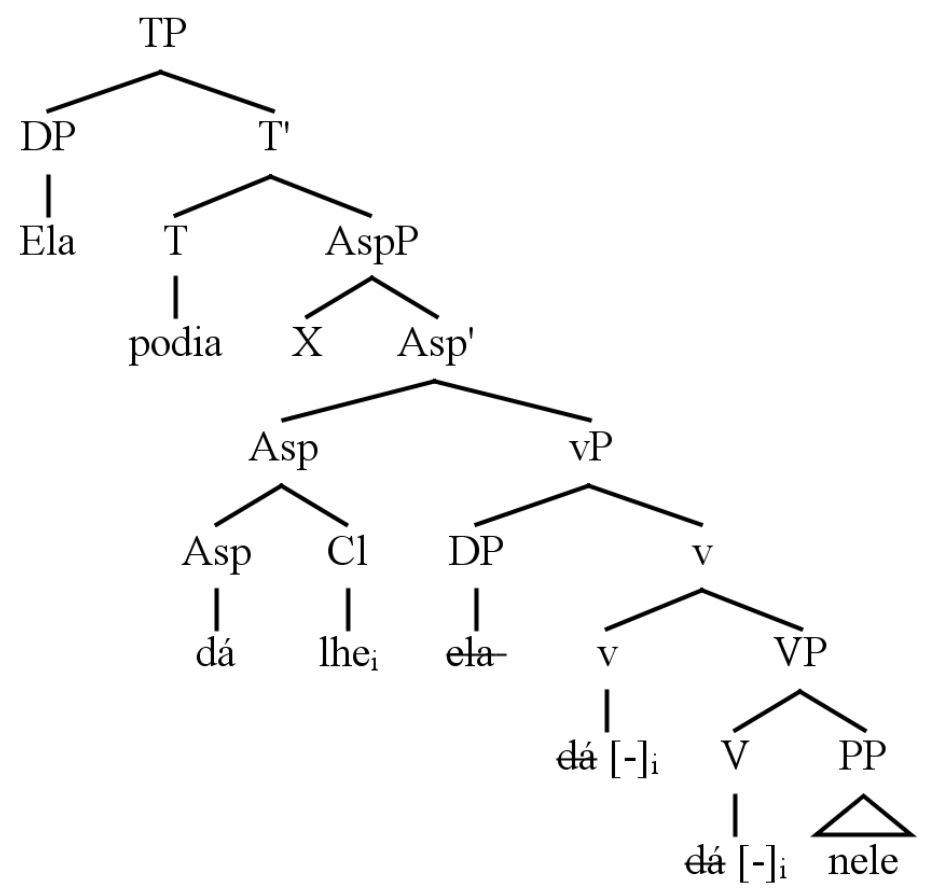




\subsubsection{O estatuto dos pronomes atemáticos eu e ele}

Nesta subseção abordo as construções citadas no item (ii) da introdução deste capítulo, relativamente ao valor categorial dos pronomes eu e ele, em sentenças exclamaticas afirmativas e exclamativas negativas, como:

Os contextos em que normalmente essas construções são produzidas, são predicados intransitivos do tipo inacusativos e inergativos:

(100) ele é de cobre ele (descreve o tipo de forno de fazer farinha)

(101) ele é cinco e meio ele (descreve a medida do forno de fazer farinha)

(102) ele é catitu ele (descreve um tipo de motor utilizado para ralar mandioca)

(103) ele já andou pelo Rio de Janeiro tudo ele

(104) ele morava no Rio de Janeiro ele

(105) ele custou cinco mil reais só o forno, é cobre ele

Essas construções são atestadas não somente em Jurussaca, mas, de modo geral, em toda a região. Trata-se de construções extremamente estigmatizadas, ao menos em Belém, e, normalmente, ocorrem de modo generalizado nas periferias. ${ }^{174}$

(106) tava precisando de dinheiro eu (Programa Barra Pesada/Belém)

$\mathrm{Na}$ projeção em (107), proponho uma representação configuracional dessas construções:

\footnotetext{
${ }^{174}$ Essas construções parecem ser atestadas na Região Amazônica como um todo. Em Belém, particularmente, elas são extremamente estigmatizadas e facilmente encontradas nas áreas mais periféricas da cidade, em todos os contextos de fala. Em alguns programas televisivos, cuja temática gira em torno de ocorrências policias e em que os repórteres entrevistam os réus e meliantes etc, essas construções são abundantes. Normalmente, faz-se alusão a elas como típicas de interlocutores tais como aqueles tematizados nos referidos programas, com clara referência ao desprestígio social dessas construções.
} 
(107) ele morava no Rio de Janeiro ele

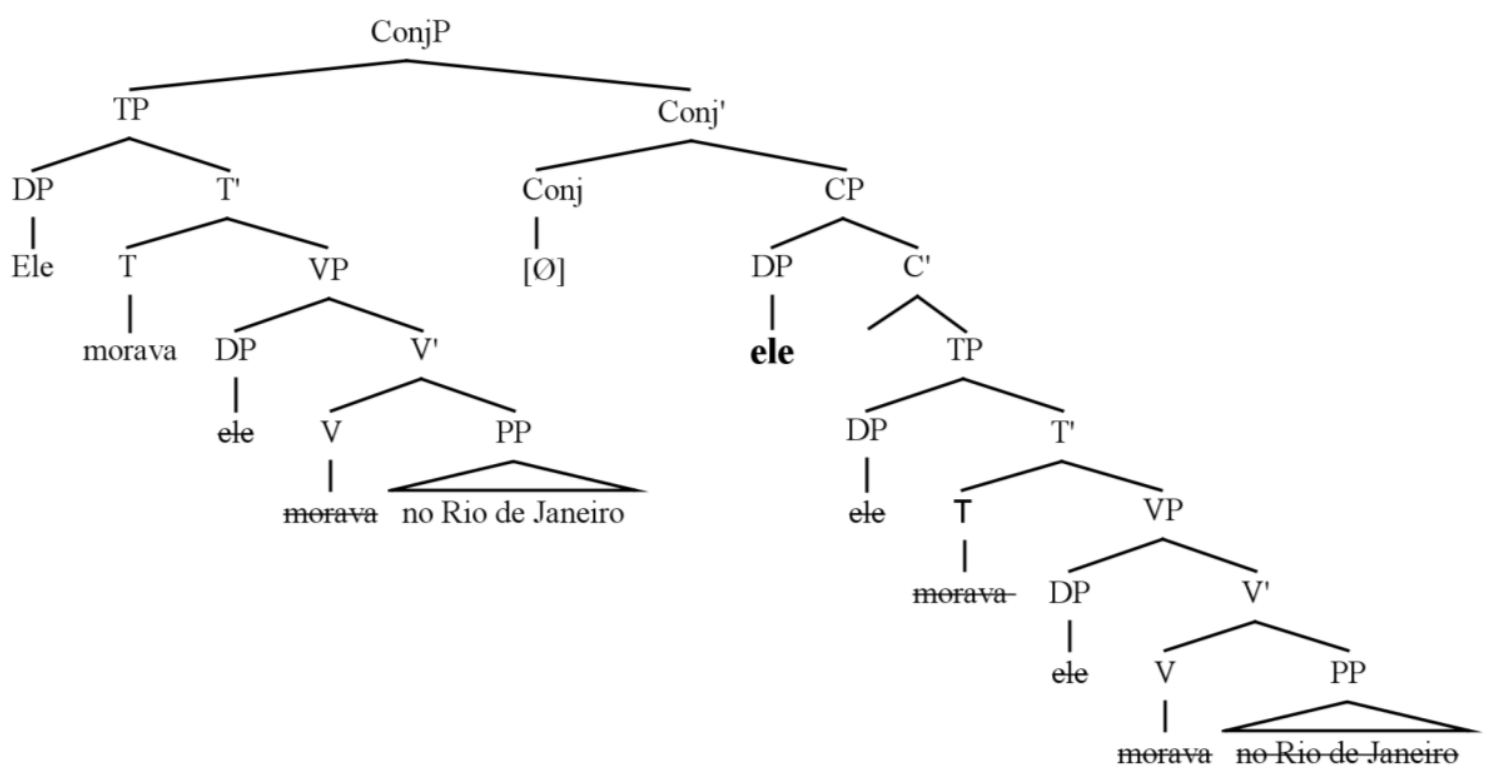

A proposta seria a de que toda a sentença "ele morava no Rio" se reduplica por meio de parataxis. No entanto, todos os elementos, exceto, o DP “ele" não estão visíveis em spell-out na parataxis. Em outras palavras, são apagados pela fonologia. Esse elemento de $1^{\mathrm{a}}$. pessoa é visível, no discurso, por meio de um abaixamento tonal, evidenciando que houve um fronteamento de sua posição de "sujeito" da sentença - na oração coordenada - para uma posição mais alta, que em termos teóricos chamamos $\mathrm{CP}$. Na representação abaixo, reproduzo a "história" do DP “ele", baseada em Jorge e Oliveira (2012, p. 265, renumerada):

(108) $[$ CP 3 [ele] c [TP <ele> 2 [Pessoa] $>$ t $[$ VP < ele 1 [Pessoa] $>$ morava [VP ...]

Seguindo Jorge \& Oliveira (2012, nota 5), a numeração 1/2/3 na representação do elemento-DP “ele" no gráfico em (108) acima tem fins 'didáticos', pois a procura de "traços" - feita por T e por C, respectivamente - é simultânea. Ratifico, portanto, como as autoras, Chomsky (2005) e outros textos a partir deste, em que a distinção entre movimento A e movimento A-barra, no sistema minimalista se dá pela chamada "derivação por fases" (phases) - cf. Chomsky (2005). Essa derivação se explica a partir do processo de transmissão dos traços presentes em núcleo das fases - notadamente as categorias $\mathrm{C} \mathrm{e} \mathrm{v*(verbo} \mathrm{leve)} \mathrm{-} \mathrm{a}$ categorias como T(empo) e V(erbo).

$\mathrm{T}$ e $\mathrm{V}$, nesse sistema, apresentam as seguintes propriedades: (i) não são categorias consideradas como fase na derivação; (ii) herdam os traços-phi de $\mathrm{C}$ e $\mathrm{v}^{*}$, respectivamente; (iii) são, enfim, categorias que apenas 
derivativamente procuram por objetos sintáticos que valorem os traços herdados; (iv) nesse sentido, são categorias que 'estocam' traços; são categorias proxy. As categorias nucleares $\mathrm{C} \mathrm{e} \mathrm{v}^{*}$ possuem, além dos traçosphi, os denominados traços edge (doravante efs). [...]

(JORGE \& OLIVEIRA, 2012, p. 264)

Voltando, portanto, à representação em (107), e ao gráfico em (108), minha análise leva em conta que, na parataxis, o EF de C atrai o elemento DP "ele" para a posição [Spec, CP]. Não se torna relevante, no entanto, nesse caso, e em virtude do que está pressuposto no sistema de fase e herança, ${ }^{175}$ definir que "tipo de posição discursiva" seja a desse DP. Com muita certeza não é de foco, nem a de tópico. Mas também não quero dizer que seja "ênfase", pois o "tipo fonológico" não parece o "enfático" - embora esta tese não tenha tratado dessa interface sintático-fonológica. O que quero dizer é que o DP "ele" checa um dado traço EF. Desnecessário, no entanto, dizer que dados como esse e estruturas como essas merecem ampla investigação.

3.4.8. O estatuto do pronome 'nวs' e sua colocação pré-verbal

- Nós ['nつs]-Complemento acusativo e dativo

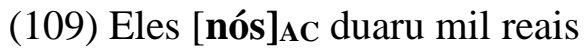

(110) Sempre, aqui eles [nós] $]_{\mathbf{A C}}$ chamavam assim...

(111) O Lula [nós]DT deu essa uma que nós tava precisando

(112) aí nós viemus pra cá, chegando aqui o Castamba [nós]DT deu aquele pedacim pra mim com a Valmira

(113) nós ia ajudar elas e elas [nós] AC ajudava

(114) sempre, aqui eles [nós] $]_{\mathbf{A C}}$ chamavam assim...

Nos exemplos (109) a (114), todas as ocorrências de Nós ['nつs] como complementos acusativo e/ou dativo têm colocação pré-verbal, semelhante à colocação proclítica das frases finitas que ocorre nas línguas românicas, exceto no português europeu. No entanto, o padrão fonológico de nós, é semelhante a um DP lexical, o que contrasta com

\footnotetext{
175 Como bem nos aponta Jorge \& Oliveira (2012: 270) para este mesmo fato em sua análise no tocante a
} fronteamento de QU relativo a foco. 
o de um verdadeiro clítico, numa assimetria entre o comportamento sintático e o prosódico da pro-forma pronominal.

Nos exemplos (111) e (112), vê-se a dupla ocorrência do pronome nós: (i) a ocorrência nominativa (nós viemos pra cá/nós ia ajudar elas) e (ii) a ocorrência dativa e acusativa (o Castamba nós deu.../elas nós ajudava).

É intrigante, pois paralelamente a essas duas possibilidades, o mesmo pronome também ocorre com a colocação pós-verbal, comum ao PVB:

(115) não, ainda num veio cum nóis aqui

(116) sempre eles falam que a prefeitura já roubou nós aqui que só a porra...

(117) é por isso que es queria muntar em cima de nóis...

Uma breve análise fonológica dos dados revelou que em todas as funções sintáticas em que ocorre a pro-forma, ela tem as seguintes características: ${ }^{176}$

1. Nós Nominativo - a forma fonética do pronome é ['nos 'nois 'noh 'noi]

2. Nós Clítico - a forma fonética desse clítico é ['nos 'nois 'noh ]

3. Nós Complemento - a forma fonética é idêntica às anteriores: ['nos 'nois 'noh ]

Portanto, como se pode observar, na $1^{\mathrm{a}}$ pessoa do plural, as formas do nominativo, do acusativo/dativo e do oblíquo são idênticas. Não há a distinção fonológica entre /nós/ 'nominativo' e /nos/ 'não nominativo' como há no $\mathrm{PB}$, com a oposição em que / $/ \mathrm{l}$ e /o/ constituem pares mínimos $(/ \mathrm{J} / \neq / \mathrm{o} /)$.

O português brasileiro, tem o seguinte inventário fonêmico de vogais:

$\begin{array}{ll}i & \text { u } \\ \text { e } & \text { o } \\ \varepsilon & \text { o }\end{array}$

a

\footnotetext{
${ }^{176}$ A análise fonológica dos dados foi feita por Del Vigna (2014).
} 
Todas essas vogais contrastam entre si, mas têm seus contrastes neutralizados em alguns ambientes fonológicos:

\section{/ i / e / e/ perdem a oposição em sílaba átona final / u/ e /o/ perdem a oposição em sílaba átona final}

A neutralização também ocorre entre /e/ e /E/ e entre /o/ e / //, em posições átonas não finais. Segundo Del Vigna (2014, $m s$.), a neutralização de contraste pode criar formas idênticas nas línguas. Em russo, a oposição entre obstruintes vozeadas e desvozeadas é neutralizada antes de silêncio, ocorrendo a homofonia entre as formas do Nominativo, conforme se vê abaixo:

NOMINATIVO
SINGULAR
snop
snop
mak
mak

\section{GENITIVO}

SINGULAR

Nos dados da fala do PAfro-indJ é possível notar que os contrastes vocálicos do PB são mantidos, mas não é possível determinar se a neutralização de contraste vocálico ocorre como no PB. Como se pode observar, na $1^{\mathrm{a}}$ pessoa do plural as formas do nominativo, do acusativo/dativo e do oblíquo são idênticas. Não há a distinção fonológica entre /nós/ 'nominativo' e /nos/ 'não nominativo' como há no $\mathrm{PB}$, em que $/ \mathrm{J} / \neq \mathrm{o} /$.

Assim, a assimetria observada no PAfro-indJ quanto ao comportamento do pronome de primeira pessoa - nós - oferece pistas para formular a hipótese de que a neutralização entre as formas "nós" e "nos" pode ter ocorrido em algum estágio da Fala de Jurussaca, acarretando a homofonia das duas formas.

A forma 'não nominativa' que, aparentemente, deixa de ser átona e comporta-se como um clítico forte, nos termos de Uriagereka, se move como um DP, adjungindo-se ao núcleo da categoria funcional em T, posição, pré-verbal, preferida dos clíticos pronominais do PB.

O exemplo (122), seguindo a proposta de movimento do clítico (forte) como um DP, teria a seguinte configuaração: 
(122) eles [nós $]_{A C}$ duaru mil reais

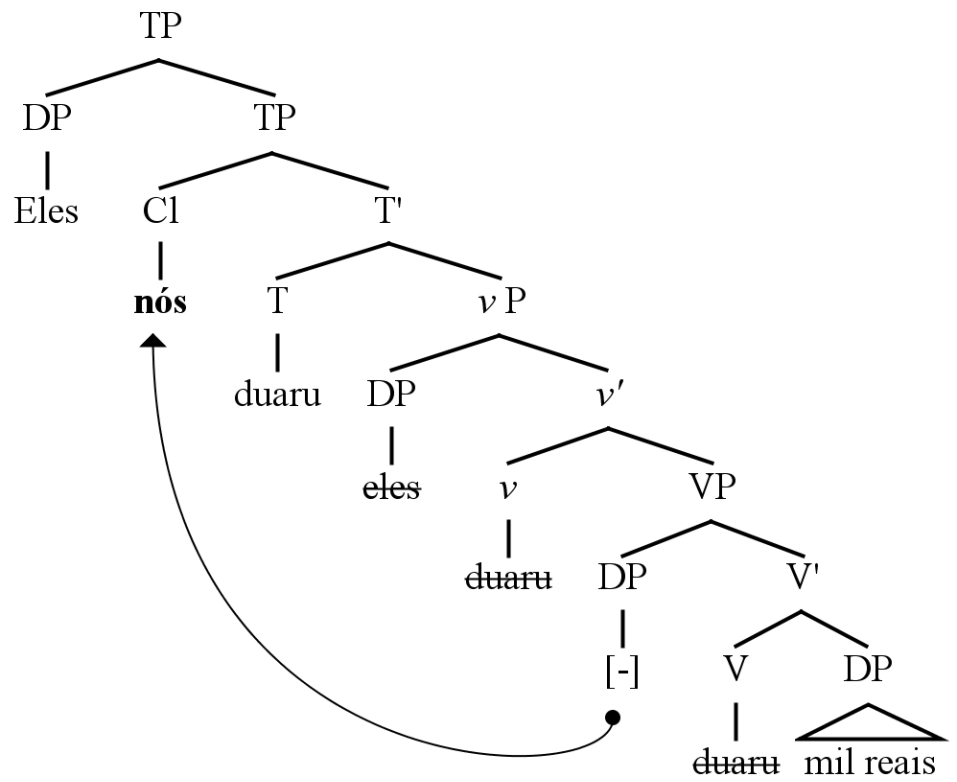

A esseas ocorrências de nós em colocação pré-verbal, verificam-se também a variação em colocação pós verbal:

- Argumento Sujeito

(123) esse aqui foi o documento que nós demu entrada no tribunal de conta (124) nesse tempo eu acho que nós tava numa faixa de quarenta e poucas família

- Complemento Direto

(125) sempre eles falam que a prefeitura já roubou nós aqui que só a porra...

- Complemento oblíquo

(126) não, ainda não veio com nós aqui...

(127) é por isso que eles querium muntar em cima de nós 


\subsubsection{As pro-formas pronominais esse/aquele um-essa/aquela uma}

As expressões esse um, essa uma, aquela uma são muito recorrentes no PAfroindJ. Elas têm as mesmas funções das pro-formas pronominais dêiticas e/ou referenciais de terceira pessoa. Tais pro-formas parecem apresentar uma simetria sintática com a pro-forma one, do inglês, analisada por Déchaine \& Wiltchko (2002) (D\&W, daqui em diante). As autoras revisitaram o estatuto categorial dos pronominais clíticos e propuseram uma nova tipologia para dar conta da descrição das pro-formas pronominais da língua ameríndia Halkomelle: são as categorias pro-DP, pro-ФP e pro-NP.

D\&W (2002, p. 419) propõem que pro-DPs são sempre argumentais, pro-ФPs são argumentais e/ou proposicionais e pro-NPs funcionam unicamente como predicados/proposições. Em inglês - uma língua que não possui clítico sintático (argumental ou predicativo) - segundo Déchaine \& Wiltchko, a proforma pronominal one é um exemplo de pro-NP em função predicativa (128): ${ }^{177}$

(128) The read $[\mathrm{car}]_{\mathrm{i}}$ is more expensive than the yellow $[\mathbf{o n e}]_{\mathrm{i}}$ (pro-NP)

- Quanto às evidências de esse um/ essa uma como pro-NP

Como argumentam D\&W, NPs são categorias que têm a sintaxe dos nomes e, portanto, espera-se de uma categoria com esta etiqueta que ela possa seguir um determinante, um quantificador ou um modificador: the one, someone, the real one.

Assim como o proforma pronominal one, do inglês, o proforma um(a) do português, pode seguir um determinante e um quantificador, mas tem algumas especificidades:

(i) é especificado por traço distintivo de gênero: (esselaquele um/ essa/aquela uma)

(ii) é especificado por traço distintivo de número, mas, contrariamente, ao gênero, é expresso apenas sintaticamente: (esse um - esses um / essa uma - essas uma)

(iii) Quanto ao traço animacidade, a pro-forma pronominal esse(a) um(a) pode ser [+/-humano].

${ }^{177}$ Exemplos retirados de Déchaine \& Wiltschko (2002, p. 428, renumerado). 
(129) Eu acho que essa uma é que num conta mais nada... porque ela tá muito velhinha (Seu Chico)

(130) ...é partida assim no meio, só que essa uma o partimento dela é um banheiro que tem no meio (Seu Valdecir)

\section{- Alguns exemplos}

(131 DOC. Essa festa pra vocês é mais importante do que a de São Benedito?

INF. Olha, essa uma...

(132) todas vem... agora essas uma vieru cum banheiro fora

(133) e chegaru no Maranhão, de lá esses um partiru pra cá

(134) não, esses um quando eles vieru, eles vieru com certeza que eles vieru passando por lá, né...

(135) pois olha aquela uma, eles fizeru esta uma não, ele agarrou mandou aumentar tudinho, mandou fazer outra, mandou avarandar tudinho aberando, fez varanda de todo lado (D. Maria José)

\subsection{Sintese do capítulo}

Neste capítulo estudei a sintaxe pronominal na variedade de portugues da comunidade quilombola de Jurussaca - PAfro-indJ. Apresentei os paradigmas das expresão casual: o paradigma nominativo, o paradigma acusativo, o paradigma dativo e o paradigma oblíquo. Em seguida, apresentei o quadro das anáforas: me, te, se, em que a forma se ocorre como default em praticamente todo o paradiga das pessoas gramaticais, exceto, na primeira.

Discuti o estatuto dos pronomes atemáticos e/ou inerentes: O clítico inerente se "ele se acabou-se...", o clítico nominativo, o estatuto morfossintático do pronome lhe em construções atemáticas "ela deu-lhe nele", o estatuto dos pronomes eu e ele "ele mora no Rio de Janeiro ele", o estatuto do pronome 'nós' [nวs] e sua colocação pré-verbal e finalmente, as pro-formas pronominais esse/aquele um - essa/aquela uma. Tanto as construções pronominais atemáticas quanto às pro-formas (esse um, essa uma) tem emprego bastante acentuado no PAfro-indJ. 


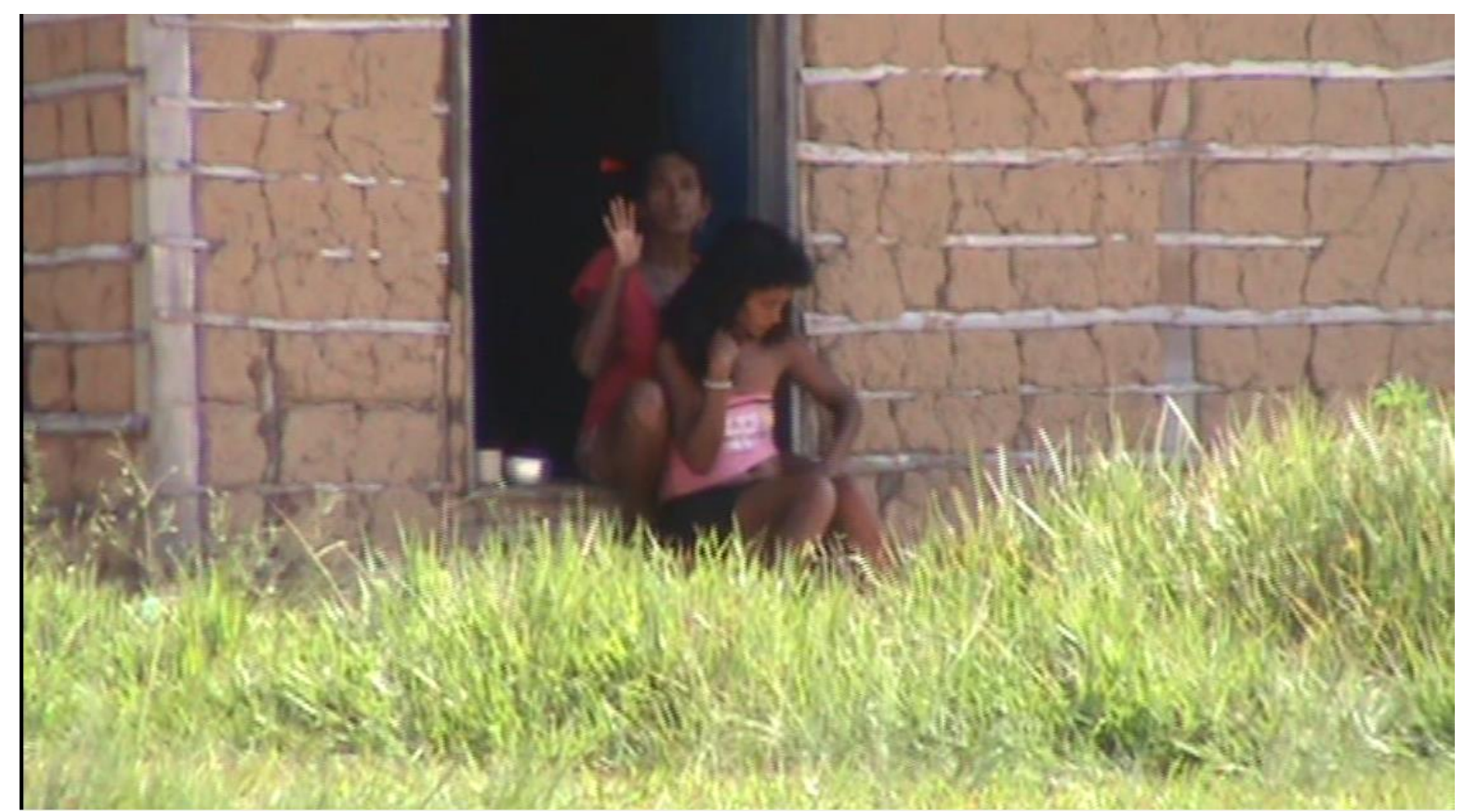

\section{Conclusão}

Nesta seção dedicada à avaliação de todo o trabalho, retomo os objetivos que motivaram sua investigação e, também, influenciaram os rumos e o percurso que foram tomados. Reafirmo as hipóteses assumidas e retomo os resultados alcançados e já discutidos no Capítulo 3. A partir do contato com a comunidade de Jurussaca, certos aspectos da variedade de português falada na comunidade foram centrais para delinear essa pesquisa. As construções pronominais já tão discutidas, como: 'Ele [nつs] ajudou' eram intrigantes se observadas sob os aspectos da colocação e da categorização das pro-formas pronominais em língua portuguesa. Logo, a decisão pela pesquisa de certos aspectos da sintaxe pronominal da variedade de Jurussaca estava tomada.

A partir da definição dos tópicos que seriam analisados, outras questões relacionadas àquela variedade de português também precisavam ser investigadas: as questões ligadas às comunidades rurais (algumas urbanas) de matriz afro-brasileira. Além do traço 'matriz afro', traços fenotípicos dos jurussaquenses insinuavam não tratar apenas de etnicidade afro mas também indígena, apontando, portanto, para um tipo de miscigenação 
muito comum na região Norte - a afro-indígena. A literatura sobre o assunto (SALLES, 2005), (GOMES, 1997), entre outros, enfoca os fenômenos de contato forjados entre as diferentes etnias no Grão-Pará. A pesquisa de Gomes (1997) sobre a formação de mocambos e quilombos na Capitania do Grão-Pará e também do Rio Negro revela um cenário cheio de movimento de fugas e de formação de quilombos na fronteira colonial, principalmente, da Guiana Francesa. Segundo Gomes (op. cit., p. 28) nesta região, especialmente no Amapá, os mocambos também foram aumentados com as constantes deserções de soldados: “(...) outro fato discutido nesta Capitania é o movimento de fugas e o surgimento de 'mocambos de índios', destacadamente a partir de 1760" (op. cit., p. 28).

$\mathrm{Na}$ área quilombola de Jurussaca, como discutido no Capítulo 1, para além de seus fundadores, provavelmente, escravos fugidos, a região era também habitada por indígenas. A etnolinguística da comunidade vem sendo atestada como afro-indígena (cf. Oliveira et alii (no prelo), Oliveira \& Praça (2013), Antunes, Oliveira \& Praça (2013). Baseando-se na morfologia territorial da comunidade, Cecim (2014, p. 81) aponta que a área fora habitada por indígenas do tronco Macro-Jê.

Portanto, a compreensão da gênese da variedade de Jurussaca passa pela compreensão das relações de contato estabelecidas entre a língua portuguesa e substratos de línguas do oeste africano e Macro-Jê. Essas relações, no entanto, são apenas apontadas como hipóteses; encontravam-se fora do escopo da minha pesquisa. Aliás, investigações de cotejo visando 'pistas' que comprovem prováveis contatos entre os substratos ligados à gênese da variedade de Jurussaca ainda não foram feitos, e, certamente, é um campo muito rico e inexplorado naquela área.

Outro objetivo da pesquisa, centrou-se nas questões mais gerais relacionadas ao português brasileiro. Esse foi um dos pontos discutidos no Capítulo 1, em que considerei que a compreensão dos fenômenos de mudança que marcam a gramática do português brasileiro (assim como de variedades, tais como as de Jurussaca) terá de levar em conta as questões sociolinguísticas que permearam as relações de contato com que a língua portuguesa teve acesso. Essa realidade linguística já foi bastante explorada no decorrer do Capítulo 1, mas retomo aqui algumas questões centrais:

(i) a existência de um fosso entre os falares da elite e os falares populares resultado da "polarização linguística brasileira" (apontado por Lucchesi, 2009); 
(ii) a situação de diglossia linguística resultante do ensino massivo tardio do português;

(iii) o isolamento de algumas comunidades, a estratificação social e a baixa escolaridade como fatores de manutenção de continua linguísticos;

(iv) o panorama histórico do Brasil Colônia cheio de movimento de fugas, rebeliões e formação de mocambos e quilombos aponta para uma forte miscigenação entre diferentes etnias, desvelando um rico cenário de contato linguístico.

A partir dos pressupostos acima apresentados, lancei luzes à necessidade de rediscussão do conceito de $\mathrm{PB}$, considerando as características que abarcam as suas noções: (i) a generalização do $P B$ nos quadros teóricos da linguística brasileira: a gênese da pseudo-homogeneidade e (ii) das especificidades do PB ou da desconstrução da pseudohomogeneidade: em busca de um continuum de português.

O objetivo 'da desconstrução da pseudo-homogeneidade do PB' não foi o de lançar novas taxonomias para abarcar a alegada "polarização linguística brasileira", mas enfocar a manutenção da proposta do continuum (proposto inicialmente por BORTONI-RICARDO, 1985) para os estudos em português brasileiro, seguindo as novas tendências baseadas em considerações de que o contato linguístico brasileiro tenha ocorrido não apenas com as línguas do oeste africano mas também com as línguas autóctones brasileiras. Assim, variedades de comunidades como Helvécia/BA e Jurussaca/PA são inseridas e ligadas no continuum de português relativamente às relações de contato linguístico, considerados em estudos que vêm sendo chamados de etnolinguísticos.

Essa hipótese pode ser reforçada a partir do argumento de Pagotto (2007) ao considerar o 'conjunto de características comuns', partilhadas pelos dialetos populares de norte a sul do Brasil: "É aqui que se localiza a unidade do português brasileiro. Dado o tamanho de nosso território é claro que se torna irresistível perguntar como esta unidade se teria dado historicamente. (PAGOTTO, 2007, p. 469)”. Nesse sentido, é interessnate considerar a 'unidade' de português junto às variedades [+marcadas] do continuum - cujos falantes têm pouca escolaridade e fazem pouco uso da escrita.

Reforçam o argumento, de compreensão do PB como variedade não monolítica, os esforços que vêm sendo empreendidos na área de políticas públicas e de direitos humanos, com um movimento de reivindicação da instituição de uma "política patrimonial" para as 
línguas brasileiras, em vistas à realidade vivenciada em inúmeras regiões do país, onde vários grupos de brasileiros falam também outras línguas que expressam visões de mundo, valores e significados fundamentais para a história e a identidade desses grupos e da própria nação. Essa reivindicação culminou com a publicação, pelo Governo Federal, por meio do Decreto-Lei N $\mathrm{N}^{0} 7.387$, de 09 de dezembro de 2010, o Inventário Nacional da Diversidade Linguística (INDL) que considera as línguas, bem como, as variedades de português faladas no país, patrimônio imaterial da humanidade e que, como tal, devem ser documentadas e reconhecidas como "referência cultural".

A partir dessas questões, ainda restava um outro objetivo da pesquisa: a investigação da sócio-história de Jurrussaca face à sua sintaxe pronominal, visando lançar luzes para a compreensão dos fenômenos ligados à sua gênese, que tiveram lugar relativamente às prováveis situações de contato. A hipótese lançada era a de que por trás das questões sobre colocação pronominal e categorização de pro-formas, fenômenos de neutralização, etc. configurem como possíveis explicações para as hipóteses sobre a 'afro-indigeneidade' de Jurussaca.

Oliveira et alii (no prelo), lançam o conceito Português Afro-indígena:

Português Afro-Indígena:

Uma variedade vernacular rural de português brasileiro L1 falada por comunidades envoltas em miscigenação afro-indígena, mas que selecionam politicamente o termo "afro" ou "indígena". Exemplificam-se as comunidades de Jurussaca/PA (autoidentificada como comunidade quilombola, logo "afro") e Almofala-Tremembé/CE (autoidentificada como comunidade indígena, mas não "afro"). Além da característica de "português L1", o português afro-indígena atesta as seguintes outras características: (i) festas de sincretismo religioso que se subdividem em dois subtipos: (a) subtipo "ladainhas" (como em "Jurussaca"); (b) subtipo "torém/torén" (como em "Almofala/Tremembé"); (ii) linguagens cerimoniais (ex.: ladainhas; a música cantada na dança do torém/torén). A variedade de português afro-indígena compartilha com as variedades de português afro-brasileira e indígena a característica de localizarem-se ao extremo [+ Marcado] do continuum dialetal de português; difere, no entanto, da variedade indígena, por ser esta L2 por definição, e da afrobrasileira, por esta variedade não contemplar o traço de miscigenação indígena.

Oliveira et alii (no prelo, seção 2)

Sigo Oliveira et alii (no prelo), na seguinte afirmação: ratifico que os conceitos de português vernacular rural: "português afro-brasileiro" em (1) e "português indígena" em (2) não abarcam variedades vernaculares rurais como as do "tipo Jurussaca" pelos principais fatos:

(i) inúmeras comunidades "isoladas" no Brasil, como Jurussaca, não podem ser ditas descendentes apenas de escravos africanos (como se afirma para 
comunidades ligadas ao conceito "afro-brasileiro" apresentado em (1)). Diferentemente, comunidades como Jurussaca, além de descenderem de escravos africanos, descendem também de grupo(s) indígena(s) como apresentado em Cecim (2014: capítulo 1, sub-seção 1.1.2);

(ii) o português vernacular rural que é falado por comunidades como as de Jurussaca, embora também de formação indígena, não pode, no entanto, ser conceituado como "português indígena" pelo fato de, diferentemente do "português indígena", não ser uma variedade de português do tipo $\mathrm{L}_{2}$. Em outras palavras, falantes de comunidades como as de Jurussaca falam uma variedade de português L1.

Oliveira et alii (no prelo, seção 2)

Oliveira et alii passam a considerar a variedade de Jurussaca, como PAfro-indJ. Corroborando essses autores, acerca da variedade de PAfro-indJ, insiro essa variedade no locus do continuum de portugues juntamente com as variedadades afro-brasileira e indídega, relativamente às situações de contato por que passa(ra)m essas comunidades:

\section{O Continuum de Português Falado no Brasil}

(Vernaculares Brasileiros [ \pm Marcados]

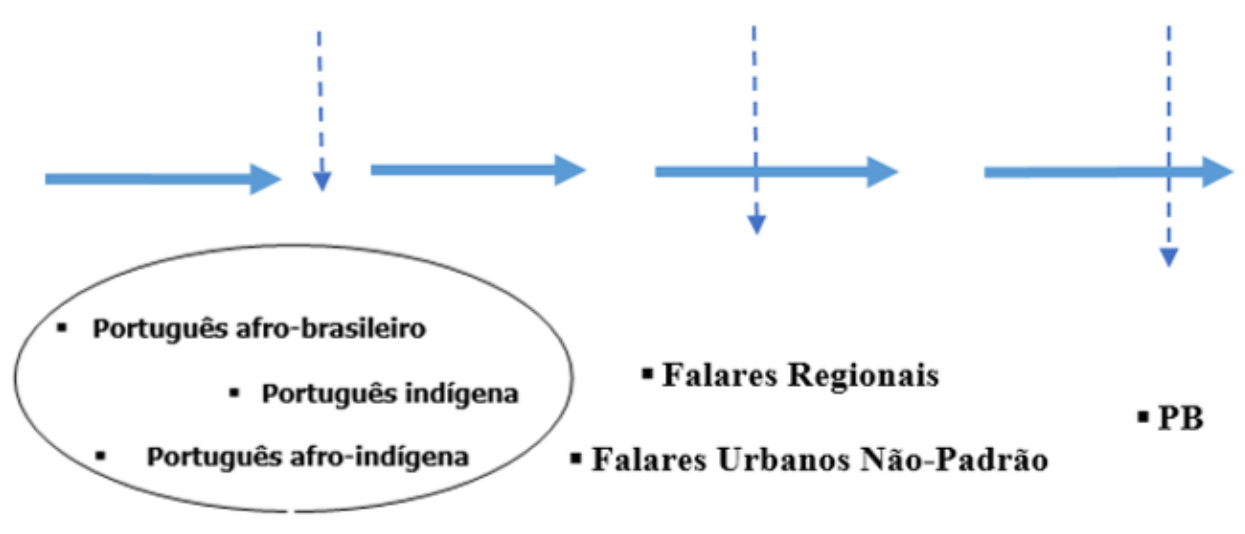

Assim, propus um continuum de português, que corrobora três tipos de falares no Brasil:

- PB [não marcado] \{modalidade falada com aproximação da escrita\}

- PVB [- marcado] \{falares regionais/ urbanos não-padrão\}

- PVB [ + marcado] \{português afro-brasileiro; indígena; afro-indígena

As análises da sintaxe pronominal do PAfro-indJ, permitem apontar: 
- Os paradigmas da expressão casual, aproximam-se da variedade [não marcada] de português, no tocante à $1^{\mathrm{a}}$. e a $2^{\mathrm{a}}$. pessoas e das variedades [não marcada] e [marcada] no tocante à $3^{\mathrm{a}}$. pessoa.

- O quadro das anáforas aproxima-se das variedades [-marcadas]: utiliza a forma se como default em praticamente todo o paradiga das pessoas gramaticais, exceto, na primeira.

- A sintaxe pronominal do PAfro-indJ presenta construções clíticas atemáticas que aproximam-se das variedades [-marcadas].

- A sintaxe pronominal do PAfro-indJ apresenta construções pronominais tônicas atemáticas 'eu e ele' que o distanciam tanto das variedades [-marcadas], quanto da [não marcada].

- A sintaxe pronominal do PAfro-indJ apresenta o uso de pro-formas pronominais 'essa uma, aquela uma' que o distancia tanto das variedades [-marcadas], quanto da [não marcada].

- Uso incomum da anáfora se e do clítico inerente se "ele se acabou-se...", incomuns nas variedades [-marcadas] e [não marcada].

- o estatuto morfossintático do pronome lhe em construções atemáticas "ela deu-lhe nele", pode aproximar o PAfro-indJ de variedades [-marcadas] e [+marcadas].

- o emprego de objeto duplo no PAfro-indJ aproxima-o de variedades [+marcadas] e [-marcadas].

- o emprego do pronome 'nos' no PAfro-indJ distancia-o das variedades [+marcadas] e [-marcadas].

No tocante ao emprego de 'nכs' é necessário considerar que essa construção ainda precisa ser analisada em cotejo com variedades de outras comunidades da região. Nas cidades próximas à comunidade, Tracuateua e Bragança, não identifiquei nenhum registro dessa construção. Uma hipótese a ser lança é a de que, possivelmente, se trata de um tipo de assimilação de traços a partir do contato com a fonologia Macro-Jê. No entato, questões desta natureza ficam em aberto.

Em consonância às possíveis situações de contato por que passou a comunidade de Jurussaca, as especificidades presentes no Quadro 16, dos pronomes pessoais, no terceiro capítulo, não são compreendidas como casos de 'recategorização' pronominal. Como já foi mencionado, a literatura brasileira vem tratando de casos de mudança no estatuto dos 
pronominais, a exemplo, o uso do pronome 'lhe' como pro-forma de segunda pessoa, como caso de recategorização em função de resultado de outros eventos, como o emprego de 'você' em lugar de tu. Em Jurussaca não apenas a pro-forma 'tu' tem alto índice de produtividade, como também a oposição 'tu' vs. 'você', correspondente aos contextos de informalidade $v s$. formalidade ou alternação relativamente ao grau de respeito é bastante produtivo. Nesse sentido que não defendo a recategorização de pro-formas pronominais como consequência de mudança por variação do uso, para as especificidades de Jurussaca. Defendo que as especificidades que ocorrem ali sejam tratadas como um processo mais complexo de 'reestruturação da gramática' em função do contato etnolinguístico e não de situações discursivas pontuais, como mencionado anteriormente.

Não foi possível apontar, para além das características etnográficas, características linguísticas que pudessem corroborar o "contato indígena" no falar PAfroInd, proposto por Oliveira et alii (no prelo) e corrobarado neste estudo. No entanto, ao final deste trabalho, ainda gostaria de mencionar a pesquisa pioneira de Cruz (1996, 2000) e Melo (2007) sobre a constatação de ideofones em comunidades remanescentes de quilombo, na região de Cametá, no Pará, denominadas nos estudos de Cruz (op cit.) como português afro-brasileiro amazônico. O traço 'amazônico' na variedade de português dessas comunidades relaciona-se fortemente com etnias indígenas. Cruz (1996) apontou 4 características fonéticas do português afro-brasileiro amazônico: (1) as alterações entre as líquidas; (2) as vogais posteriores; (3) as construções clíticas; (4) os ideofones. É interessnate destacar que a ausência de sons bilabiais nos ideofones em Cametá é hipotetizada, por Cruz, a partir da historicidade dessas comunidades com os movimentos quilombolas do Brasil Colônia ligados aos escravos fugitivos do sistema de 'plantação' - Escravos quilombolas desenvolveram uma estratégia de comunicação que envolvia não mexer os lábios, a fim de que fosse difícil para o colonizador português decifrar possíveis mensagens envolvendo rebeliões, fugas, etc.

Nos termos de Oliveira et alii (no prelo) comunidades como as identificadas por Cruz (op.cit.) como falantes de variedade de português afro-brasileiro amazônica, encaixase na definição de Português afro-Indígena e, nesse sentido, compartilham o locus [+marcado] do continuum de português brasileiro.

Assim, algumas questões levantadas no decorrer do texto, sobre a provável 'reestruturação' em certos aspectos da sintaxe pronominal da variedade de Jurussaca, podem ser corroboradas a partir de duas possibilidades (i) as questões de fundo sócio-históricas por 
que passou a comunidade com as situações de contato e (ii) a configuração sintática de certas construções pronominais, algumas próprias da variedade da comunidade, outras da expressão regional. 


\section{Bibliografia}

ABNEY, S. (1987). The English Noun Phrase and its Sentencial Aspect. PH.D. dissertation, MIT, Cambridge.

ALMEIDA, L. Fernando de (2007). Relatório de Atividades do GTDL 2006-07. Disponível em: $\quad$ http://www2.cultura.gov.br/site/wp-content/uploads/2007/12/grupo-de-trabalho-dadiversidade-linguistica-do-brasil-relatorio.pdf.

ANDERSON, Stephen (1992). A-Morphous morphology. Cambridge University Press. 2005. Aspects of the theory of clitics. New York: Oxford University Press.

ANDRADE, Aroldo Leal de. (2010). A subida de clíticos em português: Um estudo sobre a variedade europeia dos séculos XVI a XX. Tese de Doutorado. Unicamp: Campinas, SP.

ARAUJO, Edivalda. (2009). As construções de tópico. In: Lucchesi, Dante; Baxter, Alan \& Ribeiro, Ilza. O português afro-brasileiro. Salvador: edufba, 231-250.

ARGOLO, Wagner C. (2013). Colonização e Língua Geral: o caso do sul da Bahia. PAPIA, 23 (1), ps. 75-96.

ASSUNÇÃO, P de. (2009). Mazagão: cidade em dois continentes. Usjt - arq.ubr $n^{0} 2$, p. 2255. Disponíve em: http://www.usjt.br/arq.urb/numero_02/artigo_paulo.pdf

AUGER, Julie (1994) Pronominal Clitics in Québec Colloquial French: A Morphological Analysis. Ph.D. Dissertation. University of Pennsylvania. Philadelphia.

BAGNO, Marcos. (2011). Gramática pedagógica do português brasileiro. São Paulo: Parábola.

BAXTER, Alan N. (1995). Transmissão Geracional Irregular na História do Português Brasileiro - divergências nas vertentes afro-brasileiras. Revista Internacional de Língua Portuguesa, v. 14, ps. 72-90.

. (2002). Semicreolization? - The restructured portuguese of the tongas of São Tomé - a consequence of L1 acquisition in a special contact situation. Journal of Portuguese Linguistics 1: 7-39.

(2004). The development of variable NP plural agreement in a restructured african variety of portuguese. In Geneviève Escure \& Armin Schwegler (eds.), Creoles, contact, and language change: linguistic and social implications, vol. 27, 97-126. Amsterdam: John Benjamins.

BAXTER, A. N., LOPES, N. (2011). A concordância verbal variável no português dos Tongas. PAPIA 21 (1) ps. 29-50.

BECHARA, Evanildo. (2009) Moderna gramática portuguesa. $37^{\mathrm{a}}$ ed. Rio de Janeiro: Nova Fronteira/Lucerna.

BENVENISTE, Émile. (1976). Problemas de Linguística Geral I. 5 ed. São Paulo: Companhia Editora Nacional/ EDUSP.

BEZERRA NETO, José M. (2012[2001]) Escravidão negra no Grão-Pará - sécs. XVII-XIX. $2^{a}$. ed.(revisada e ampliada) ed. Paka-Tatu: Belém.

BISOL, Leda. (1992). O acento: duas alternativas de análise. Cadernos de Estudos Linguísticos 22. Campinas: IEL, Unicamp.

BLOOMFIELD, L. (1933) Language. New York. 
BONET, Eulália. (1991). Morphology after syntax: pronominal clitics in romance. Ph.D. dissertation. MIT.

BONVINI, Emílio. (2008). Línguas africanas e português falado no Brasil. In FIORIN, José Luiz \& PETTER, M. (orgs.). África no Brasil - a formação da língua portuguesa. São Paulo: Ed. Contexto, 15-73.

BORBA, F. da Silva. (ogr.) (2004). Dicionário UNESP do português contemporâneo. Sâo Paulo: UNESP.

BORER, Hagit. (1981). Parametric variation in clitic constructions. Phd Dissertation. MIT: Cambridge.

BORTONI-RICARDO, S. M. (1985). The Urbanization of rural dialect speakers: $a$ sociolinguistic study in Brazil. Cambridge: Cambridge University Press.

BRAGANÇA (2014). In: WIKIPÉDIA, Flórida: Wikimedia Foundation, 2014. Disponível em http://pt.wikipedia.org/wiki/Bragan\%C3\%A7a \%28Par\%C3\%A1\%29. Acesso em: 12.07.14.

BRITO, A. M., DUARTE, I. MATOS, G. (2003). Tipologia e distribuição das expressões nominais. In MATEUS, M. H. M. et alii. Gramática da Língua Portuguesa. 5a. ed. Lisboa: Editora Caminho, ps. 796-867.

CAMACHO TABOADA, Maria Victoria. (2006). La arquiquitectura de la gramática - Los clíticos pronominales románicos y eslavos. Secretria de Publicaciones, Universidad de Sevilla. Serie: Linguistica, $\mathrm{n}^{0} 27$.

CÂMARA JR. J. M. (1972). Princípios de Linguística Geral. 4ª ed. Rio de Janeiro: Acadêmica.

(1996[1970]). Estrutura da Língua Portuguesa. 24a . ed. Petrópolis: Vozes.

CAMARGO, Marcelo/ABr (2014). Foto: Professores mantém greve em São Paulo. Portal Bragança. http://noticias.portalbraganca.com.br/nacional/educacao-professores-da-redepublica-estadual-de-sao-paulo-decidem-manter-a-greve.php. Acesso em fevereiro de 2014.

CAMPOS, Ednalvo A. (2011) O uso dos pronomes nós e a gente no gênero entrevista da mídia televisiva uma análise do português culto falado em Belém. In: I SIMELP, São Paulo: Anais do $I$ SIMELP $\quad-\quad$ disponível em endereço eletrônico. $<$ http://www.fflch.usp.br/eventos/simelp/new/pdf/slp36/04.pdf $>$. Acesso em 16 de março de 2011.

CARDINALETTI, A. \& STARKE, M. (1999). The typology of structural deficiency: On the three grammatical classes. In: Henk van Riemsdijk. ed.. Clitics in the Languages of Europe, Empirical Approaches to Language Typology. Berlin: Mouton de Gruyter, 145-233.

CARVALHO, Danniel da S. (2008) A estrutura interna dos pronomes pessoais em Português Brasileiro. Tese de doutorado. UFAL, Maceió, AL.

CASTILHO, Ataliba Teixeira de. (2006). Texto de Apresentação in JURBAN, Clélia Cândida A. \& KOCH, Ingedore G. V (Orgs.). Gramática do Português culto falado no Brasil - construindo o texto falado I. Campinas, SP: Editora da Unicamp.

. (2002). Texto de Apresentação do Projeto de Gramática do Português Falado.

in CASTILHO, A. T. (Org.). Gramática do Português Falado Vol. I: A ordem. Ed. Unicamp: Campinas, SP. 9-24.

CASTILHO, A. T. \& EliAS, V. M. (2012) Pequena Gramática do Português Brasileiro. São Paulo: Contexto. 
CECIM, Jair. (2014). O português afro-indígena de Jurussaca-PA: Revisitando a descrição do sistema pronominal pessoal da comunidade a partir da textualidade. Tese de Doutorado. Universidade de São Paulo.

CHOMSKY, N. (1981). Lectures on Government and Binding. Dordrecht: Foris. (1986). Knowledge of Language: Its nature, origin and use. Praeger: Conneticut: London. (1995a). The Minimalist Program. Cambridge, MA: MIT Press.

. (1995b). Bare Phrase Structure. In WEBELHUTH, Gert. (ed.) Government and Binding Theory and the Minimalist Program: Principles and Parameters in Syntactic Theory. Oxford (UK)/Cambridge (USA): Blackwell, p. 383-439.

(1999a) Derivation by Phase. MIT Occasional Papers in Linguistics. 18. Cambridge, MA: MIT Orking Papers ins Linguistics.

Caminho.

(1999b) O Programa Minimalista. (Trad. Eduardo Paiva Raposo). Lisboa: (2005). On Phases. Ms, MIT.

COELHO, Adolpho. (1967). Notas Suplementares. Boletim da Sociedade de Geografia de Lisboa. 1880. Reproduzido em Estudos Linguísticos Crioulos, p. 129-196.

COLLISCHONN, G. (1993). Um estudo do acento secundário em português. Dissertação de Mestrado, UFRGS: Porto Alegre, RS.

COSTA, João. (2008). O advérbio em português europeu. Edições Colibri, Lisboa, Portugal.

COSTA, João \& Costa, Ana. (2001). O que é um advérbio. Edições Colibri, Lisboa, Portugal.

COUTO, H. H. (2009). Linguística, ecologia e ecolinguística: contato de línguas. São Paulo: Contexto.

CRUZ, Regina. F. (1996). Aspectos fonético-fonológicos do português afro-brasileiro. Proceedings of XI Encontro Nacional da ANPOLL (Associação Nacional de Pós-Graduação em Letras e Linguística). João Pessoa. http://www.ling.su.se/Creole/Papers_Online.html\#Fernandes_Cruz-1.

(2000). Analyse Acoustique et Phonologique du Portugais Parlé par les Communautés Noires de l'Amazonie (Brésil). Tese de Doutorado. Université de Provence, França.

CUNDA, Cristiane (2009) Os índios brasileiros - reportagem. In Novo Hamburgo.org. Disponível http://novohamburgo.org/site/queromais/reportagens/2009/04/19/os_indios brasileiros_2009 0419/. Acesso em: 14.07.2014.

CYRINO, S. M. L. (2000) O objeto nulo no português brasileiro in Gärtner, E., Hundte, C \& Schönberger, A. (orgs.) Estudos de gramática portuguesa, vol III, Frankfurt am Main, TFM, p. 61-73.

(2010a) On complex predicates in Brazilian Portuguese. Iberia: An International Journal of Theoretical Linguistics. V1 2.2, 1-21. Disponível em: http://www.siff.us.es/index.php/ij/index. 
(2010b). On romance syntactic complex predicates: Why Brazilian Portuguese

is different. Estudos da Língua(gem), 8(1), pp. 187-222. (disponível em http://www.estudosdalinguagem.org/seer/)

DE CAT, Cécile. (2005). French subject clitics are not agreement markers. Lingua 115. Elsevier Sciense. $\quad$ P. $1195-1219 \quad-\quad$ Disponível em: http://www.sciencedirect.com/science/article/pii/S0024384104000506. Acesso em 25.03.2013.

DÉCHAINE, Rose-Marie \& WILTSCHKO, Martina. (2002). Decomposing Pronouns. Linguistic Inquiry, Vol. 33, Number 3: MIT, 409-442.

DEL VIGNA, Dalva (2014). Breves considerações fonológicas sobre a $1^{\mathrm{a}}$. pessoa do plural na norma de Jurussaca. Ms.

DUARTE, M. E. L. (1996) Do pronome nulo ao pronome pleno: a trajetória do sujeito no português do Brasil. In: I. Roberts \& Kato, Mary A. (orgs.) Português brasileiro: uma viagem diacrônica - homenagem a Fernando Tarallo. $2^{\mathrm{a}}$ ed. Campinas: SP: Editora da Unicamp, p. 107-128. Coleção repertórios.

DUARTE, I \& MATOS, G. (2000). Romance Clitics and the Minimalist Program in COSTA, João. Portuguese Sintax New Comparative Studies. New York: Oxford University Press. p. 116-142.

DUARTE, I; MATOS, G \& GONÇALVES, A. (2005). Pronominal clitics in european and brazilian portuguese. In Journal of Portuguese Linguistics, Vl. 4, $N^{o}$. 2. Edições Colibri AEJPL: Lisboa, PT. p. 113-141.

EVERETT, Daniel L. (1996). Why there are no clitics an alternative persperctive on pronominal allomorphy. University of Texas.

FERGUSON, C. A. (1974). Diglossia. In: FONSECA, Maria S. V.; NEVES, Moema F. (Orgs.). Sociolinguística. Rio de Janeiro: Eldorado, p. 99-117.

FERNANDES, J. T. V. (2008). Corpus de pesquisa "Aspectos da enunciação da comunidade de Jurussaca - uma abordagem da dêixis pronominal. Manuscrito. Novembro de 2008. Manuscrito. pdf. Disponível em: 〈http://www.fflch.usp.br/indl/arquivos/> .

FIGUEIREDO, C. F. G. (2010). A concordância plural variável no sintagma nominal do português reestruturado da comunidade de Almoxarife, São Tomé: desenvolvimento das regras de concordância variáveis no processo de transmissão-aquisição geracional, vols. 1 $e$ 2. Dissertação de doutorado. Macau: Universidade de Macau - Faculdade de Ciências Sociais e Humanas, Departamento de Português.

FIGUEIREDO, C.F.G., OLIVEIRA, M.S.D. (2013), Português do Libolo, Angola, e português afro-indígena de Jurussaca, Brasil: cotejando os sistemas de pronominalização. Revista PAPIA 23(2), p. 105-185.

Folha de São Paulo, Opinião Editoriais (2014). Fonte: http://www1.folha.uol.com.br/fsp/opiniao/150481-hipocrisia-eleitoral.shtml. Acesso em 03.02.2014.

GALVES, C. (2001a). Clíticos e Concordância em Português. In Galves, C. Ensaios sobre as gramáticas do português. Editora da Unicamp. Campinas: São Paulo, p. 125-152.

(2001b). A sintaxe pronominal do português brasileiro e a tipologia dos pronomes. In Galves, C. Ensaios sobre as gramáticas do português. Editora da Unicamp. Campinas: São Paulo, p. 153-179. 
(2000). Agreement, predication and pronouns in the history of portuguese. In COSTA, João. Portuguese Sintax New Comparative Studies. New York: Oxford University Press. ps.143-168.

\& ABAURRE, M. B M. (2002 [1992]) Os clíticos no português brasileiro: elementos para uma abordagem sintático-fonológica. In CASTILHO, A. \& BASÍLIO, M. (Orgs.) Gramática do Português Falado. Vol. IV Estudos Descritivos. $2^{\mathrm{a}}$. ed Rev.. Campinas, São Paulo: Editora Unicamp, p.267-312.

RIBEIRO, I \& TORRES MORAIS. M.A. (2005). Syntax and morphology in the placement of clitics in european portuguese and brazilian portuguese. In Jounal of Portuguese Linguistics (org.) KATO, M. \& PERES, J. A. Vol $4 \mathrm{~N}^{\circ} .2$,

GOMES, Christina Abreu, (2003a). Variação e mudança na expressão do dativo no português brasileiro. In PAIVA, M. da C. de \& DUARTE, M. E. L. (Orgs.) Mudança Linguística em tempo real. Rio de Janeiro: Contra Capa, ps. 81-96.

. (2003b). Dative alternation in Brazilian Portuguese: typology and constraints.

Language Design 5. p. 67-78. Disponível em: http://elies.rediris.es/Language_Design/LD5/abreu.pdf. Acessado em 10.01.10.

GOMES. Flávio dos S. (1997) A hidra e os pântanos: quilombos e mocambos no Brasil (sécs.XVII-XIX). Tese de Doutorado em História. Unicamp.

GONÇALVES, Anabela P. L. (1999). Predicados Complexos Verbais em contextos de Infinitivo não Flexionado do Português Europeu. Universidade de Lisboa: Lisboa. Tese de Doutoramento.

(2013) Seminários de Sintaxe, Guião 2. Universidade de Lisboa, ms. GONÇALVES, Rita. (2010). A Colocação dos Pronomes Clíticos no Português Oral de S. Tomé: análise e discussão de contextos numa perspectiva comparativa. Universidade de Lisboa, Dissertação de Mestrado.

GONÇALVES, Perpétua \& CHRISTOPHER, Stroud (orgs.). (1998). Panorama do português oral de Maputo - Volume III: estruturas gramaticais do português - problemas e aplicações. Cadernos de pesquisa $\mathrm{N}^{\circ} 27$ - Moçambique. Maputo: Instituto Nacional do Desenvolvimento da Educação.

Casa da Moeda.

(2010). A génese do português de Moçambique. Lisboa: Imprensa Nacional-

GUEDES, M. \& BERLINCK, R.de A. (orgs.). (2000). E os preços eram commodos... Anúncios de jornais brasileiros - século XIX. Série Diachronica, Vol 1. São Paulo: Humanitas/FFLGC/USP.

GUY, Gregory. (1981). Linguistic Variation in Brazilian Portuguese: Aspects of Phonology, Syntax and Language History. Phd Dissertation, University of Pennsylvania. Ann Arbor: University Microfilms.

HARLEY, H. \& RITTER, E. (2002). Person and number in pronouns: a feature-geometric analysis. Language 78. P 482-526.

HOLM, John. 1987. Creole influence on Popular Brazilian Portuguese. In: G. Gilbert (ed.). Pidgin and Creole Languages, p. 406-429. Honolulu: University of Hawaii Press.

. (2009). The genesis of the Brazilian Vernacular: Insights from the indigenization of Portuguese in Angola. PAPIA 19, p. 93-122.

(2004).... 
HORNSTEIN, N. NUNES, J. \& GROHMANN, K. (2010). Understand Minimalism. Cambridge University Press.

INVERNO, Liliane Cristina Coragem. (2005). Angola's Transition to Vernacular Portugues. Dissertação de Mestrado. Faculdade de Letras, Universidade de Coimbra.

JON-AND, Anna. (2011). Variação, contato e mudança linguística em Moçambique e Cabo Verde: a concordância variável de número em sintagmas nominais do português. Tese de Doutorado. Stockholm University: Faculty of Humanities, Department of Spanish, Portuguese and Latin American Studies.

JORGE, L. OLIVEIRA, M. S. D. 2012. Por Que Que é Assim? - Considerações sobre o fronteamento de QU em línguas crioluas do Atlântico e o português do Brasil. PAPIA 22(2). ps. 253-277.

KATO, M. A. (1999). Strong pronominals in the subject parameter. Probus: 11, p. 1-37, 19.

KATO, M.; NUNES, J. (2009). A uniform raising analysis for standard and nonstandard relative clauses in Brazilian Portuguese. In: NUNES, J. (Org.) Minimalist essays on Brazilian Portuguese syntax. Philadelphia: John Benjamins Publishing, ps. 93-120.

KAYNE, R.S. (1975). French Syntax: The Transformacional Cycle. Cambridge: MIT Press. Mass. $\mathrm{N}^{\mathrm{o}} 4$, p. 647-683.

(1991). Romance Clitics, Verb Movment and PRO. Linguistic Inquiry, Vol. 22,

(1983). Chains, categories external to $S$, and French complex inversion. Natural Language and Linguistic Theory 1, p. 107-139.

KLAVANS, Judith. (1982). Some problems in the theory of clitics. Bloomington: Indiana University Linguistics Club. [Thesis doctoral, University College, Londres. 1980]

61: 95-120.

(1985). The independence of syntax and phonology in cliticization. Language

(1995). On clitics and cliticization: the interaction of morphology, phonology and syntax. [Outstanding Dissertations in Linguistics] New York and London: Garland Press.

KROCH, A. (2001). Syntactic change. BALTIN, M., COLLINS, C. (orgs.). The handbook of contemporany syntactic theory. Oxford: Blackwell.

LADEIRA, M. E. (2012). Timbira, nossas coisas e saberes: Coleções de museus e produção da vida. São Paulo: CTI - Centro de Trabalho Indigenista. Disponível em: https://pt.scribd.com/doc/138754280/Nossas-Coisas-e-Saberes-Timbira-2013.

LAKA, Itziar. (1991) Negative Fronting in Romance: Movement to $\Sigma$. Ms. University of Rochester.

LARSON, Richard K. (1988). On the double object construction. Linguist Inquiry, vl. 19. p. 335-91.

LEITE, Marli Q. (2005) Variação Linguística: dialetos e norma linguística. In SILVA, Luiz A. da.(org.) A Língua que Falamos - Português: história, variação e discurso. São Paulo: Globo, p. 183-210.

LONGOBARDI, Giuseppe. (1994). Reference and Proper Names: A Theory of N-Movement in Syntax and Logical Form. Linguistic Inquiry, ps. 609-665. 
LUCCHESI, D. (2002). A transcrição de textos orais. Disponível em: http://www.vertentes.ufba.br/images/paginas/projeto/chave_de_transcricao.pdf. Acesso em: 25 maio. 2010.

(2009a). Introdução. In Lucchesi, D.; Baxter, A. \& Ribeiro, I. O português afro-brasileiro. Salvador, Bahia: EDUFBA, p. 27-41.

(2009b). Conclusão. In Lucchesi, D.; Baxter, A.; Ribeiro, I. O português afrobrasileiro. Salvador: EDUFBA. p.513 a 545.

(2002). Norma linguística e realidade social. In: Marcos Bagno. (Org.). Linguística da Norma. 1' . ed. São Paulo: Loyola, v. 1, p. 63-92.

\& MELLO, Camila. (2009). A alternância dativa no português afro-brasileiro: um processo de reestruturação original da gramática. PAPIA 19. p 153-184.

MARTINS, Ana Maria (2013). A posição dos pronomes pessoais clíticos. In Gramática do Português. A. Mendes, M. F. Bacelar do Nascimento, M. A. Mota, E. Paiva Raposo, L. Segura, M. C. Viana (Orgs.). Lisboa: Gulbenkian.

Doutoramento.

(1996). A história do clítico no português. Universidade de Lisboa. Tese de

MARTINS, Nilce Santana. (1988). História da Língua Portuguesa V: século XIX. Editora Ática: São Paulo.

MATEUS, M. H. Mira et alii. (2003). Gramática da Língua Portuguesa. 5a. ed. Lisboa: Editora Caminho.

MELO, Helane de F. F. (2007). Ideofones: um estudo no Falar Paraense. Dissertação de Mestrado. UFPA

MELLO, H. R. (1996). The Genesis and the Development of Brazilian Vernacular Portuguese. Tese de Doutorado. University of New York.

MIOTO, Carlos et alii. (2005). Novo manual de sintaxe.2a ${ }^{\text {a }}$ Ed. Insular: Florianópolis.

MOISÉS, Massaud. (1995). História da Literatura Brasileira: das origens ao Romantismo. São Paulo: Matins Fontes.

MÜLLER, Gilvan. (2005). Política Linguística na e para além da Educação Formal. Estudos Linguísticos $n^{\circ} \quad X X X I V, \quad$ p. 87-94. Disponível em: http://www.gel.org.br/estudoslinguisticos/edicoesanteriores/4publica-estudos-2005/ 4publica-estudos-2005-pdfs/1-convidado-gilvan.pdf. Acesso, 16.05.2014.

MYERS-SCOTTON, Carol. (2002). Contact linguistics: Bilingual Encounters and Grammatical Outcomes. New York: Oxford University Press.

NAEA. (2005). Quilombos do Pará, Cd-rom. Belém: NAEA-UFPA \& Programa Raízes.

NARO, Anthony \& SCHERRE, Marta. (1993). Sobre as origens do Português Popular do Brasil. Revista D.E.L.T.A., p. 437-454. São Paulo, 9, nº especial. . (2007). Origens do português brasileiro. São Paulo: Parábola.

NOLL, Volker. (2008). O Português Brasileiro - formação e contrastes; traduzido por Viaro, Mário Eduardo. São Paulo: Globo, 2008.

OMENA, N. P. de. (1986). A referência variável da primeira pessoa do discurso no plural. In: NARO, Anthony et alii. Relatório Final de Pesquisa: Projeto Subsídios do Projeto Censo à Educação. Rio de Janeiro, UFRJ, V. 2. p.286-319. 
OLIVEIRA, M. S. D. de; CAMPOS, E. A.; FERNANDES, J. T. V. (2011). Repensando a escola em Jurussaca a partir da 'norma dos pronomes pessoais da comunidade'. In: CUNHA, A. S. de A. (Org.). Entendendo quilombos, desconstruindo mitos - a educação formal e a realidade quilombola no Brasil. 1 ed. Guimarães, MA: SETAGRAF, v. 1, p. 129-144.

OLIVEIRA, M. S. D de. et alii. O Conceito de Português Afro-Indígena e a Comunidade de Jurussaca. (no prelo) In: Juanito Avelar, \& Laura Álvarez (orgs.). Dinâmicas afro- latinas: línguas e histórias. SUP - Stockholm University Press.

PAGOTTO, E. (1993). Clíticos, mudança e seleção natural. In: Roberts, I. \& M. Kato. orgs. Português Brasileiro. Uma Viagem Diacrônica. Campinas: Editora da UNICAMP, 185-206.

de Mestrado: Unicamp.

(1992) A posição dos clíticos em português: um estudo diacrônico. Dissertação (2007) Crioulo sim, crioulo não, uma agenda de problemas. In: CASTILHO, A. TORRES MORAIS, M. A. T.; LOPES, R. E. V.; CYRINO, S. M. L. (Orgs.). Descrição, história e aquisição do português brasileiro. Campinas, SP: Pontes, FAPESPS, p. 461-483.

PAIXÃO DE SOUSA, M. C. (2006). Linguística Histórica. PFEIFFER, C.; NUNES, J. H. (Org.). Introdução às Ciências da Linguagem: Língua, Sociedade e Conhecimento. Campinas: Pontes, v. 3, p. 11-48.

PARÁ 30 GRAUS: RECURSOS HÍDRICOS (2012). Divisão do estado em regiões hidrográficas segundo a proposta de gerenciamento dos recursos hídricos do Estado do Pará. Disponível em: http://www.para30graus.pa.gov.br/apresenta.htm. Acesso em 12.07.14.

PERINI, Mário A. (2010). Gramática do Português Brasileiro. São Paulo: Parábola.

PETTER, M. T. (2008) Variedades Linguísticas em contato: português angolano, português brasileiro e português moçambicano. Tese de Livre Docência: Universidade de São Paulo.

PETTER, M. M. T.; OLIVEIRA, M. S. D. (2012). Novas luzes sobre a descrição do português afro-brasileiro. In: III SIMELP, 2012, Macau. III SIMELP: a formação de novas gerações de falantes de português no mundo. Macau: Universidade de Macau, v. 1. p. 403409.

PETTER, M. M. T. \& OLIVEIRA, M. S. D. Novas luzes sobre a descrição do português afro-brasileiro. In: III SIMELP, 2012, Macau. III SIMELP: a formação de novas gerações de falantes de português no mundo. Macau: Universidade de Macau, 2012. v. 1. p. 403-409.

PETTER, M. T.; OLIVEIRA, M. S. D. de. (2011a) Projeto-Piloto $n^{\circ} .20173$ - Leia Mais. VI. Comunidade de Jurussaca - Município de Tracuateua - Pará. Março de 2011. Disponível em: http://www.fflch.usp.br/indl/Extra/Projeto_Iphan_USP.htm. Acesso em 16 de março de 2011.

PETTER, M. T. \& Oliveira, M. S. D. de. (2011b). Transcrições. Conversa com Seu Chico, do minuto 0:13:00 a 0:27:00 In Petter, M. T. \& Oliveira, M. S. D. de. 2011. Projeto-piloto IPHAN/USP. Disponível em: http://www.fflch.usp.br/dl/indl/transcricao detalhe.php?id=33\&idc=58. Acesso em 02 de abril de 2014 .

PETTER, M. T. \& Oliveira, M. S. D. de. (2011c). Transcrições. Conversa com Seu Edvaldo e D. Lúcia: In Petter, M. T. \& Oliveira, M. S. D. de. 2011. Projeto-piloto IPHAN/USP. Disponível em: http://www.fflch.usp.br/dl/indl/transcricao detalhe.php?id=33\&idc=58. Acesso em 02 de abril de 2014.

PETTER, M. T. \& Oliveira, M. S. D. de. (2011d). Transcrições. Conversa com Dona Antônia, do minuto 0:00:00 a 0:13:31. In: Petter, M. T. \& Oliveira, M. S. D. de. 2011. 
Projetopiloto IPHAN/USP. Disponível em: http://www.fflch.usp.br/dl/indl/transcricao_ detalhe.php?id=27\&idc=6. Acesso em 02.de abril de 2014.

PETTER, M. T. \& Oliveira, M. S. D. de. (2011e). Transcrições. Conversa com Dona Fausta e Seu Manoel, do minuto 00 a 0:13:36. In: Petter, M. T. \& Oliveira, M. S. D. de. 2011. Projeto piloto IPHAN/USP. Disponível em: http://www.fflch.usp.br/dl/indl/transcricao detalhe.php?id=27\&idc=6. Acesso em 02.de abril de 2014 .

PETERSON, Carol. (2008). A Tripartição Pronominal e o estatuto das proformas cê, ocê e você. Delta 24.2: 283-308. São Paulo: PUC-SP.

PINTO, Rolando Morel. (1988). História da Língua Portuguesa IV: século XVIII. Editora Ática: São Paulo.

PIMENTEL PINTO, Edith. (1988). História da Língua Portuguesa VI: século XX. Editora Ática: São Paulo.

POSTAL, P. M. (1966a). A note on undestood transitively. International Journal of American Linguistics 32, 90-93.

(1969) On so-colled "pronouns" in English. In REIBEL, D.A. \& SCHANE, S. A. (eds.) Modern Studies in English: Readings in Transformational Grammar. Prentice Hall, Englewood Cliffs. 201-224.

PRETI, Jubran. (2003). Apresentação. In: Preti, Jubran. (Org.). Análise de textos orais. 6 ed. São Paulo: Humanitas, FFLCH/USP. Série Projetos Paralelos. Vol. 1.

RAMOS, Jânia. (1996). O uso das formas você, ocê e cê no dialeto mineiro. In: Hora, D. org.. Diversidade linguística no Brasil. João Pessoa: Ideia Editora, 43-60.

RAPOSO, E. (2000). Clitic position and verb movement in European Portuguese. in COSTA, João. Portuguese Sintax: New Comparative Studies. Oxford University Press. New York, 266-297.

\& URIAGEREKA J. (2005). Clitic Placement in Western Iberian: a Minimalist View. In The Oxford Handbook of Comparative Syntax (G. Cinque \& R. Kayne, editors) pp. 639-697. Oxford: Oxford University Press.

(1999) Some observation in the pronominal system of portuguese in BORRAS, Z \& SOLA, J. (eds.) Catalan Working Papers. Linguistics 6: 59-93.

(1992) Teoria da Gramática: A Faculdade da Linguagem. Ed. Caminho: Lisboa.

Relatório de Atividades (2006-07) do Grupo de Trabalho da Diversidade Linguística do Brasil (GTDL), Disponível em: http://www2.cultura.gov.br/site/wpcontent/uploads/2007/12/grupo-de-trabalho-da-diversidade-linguistica-do-brasil-relatorio.pdf

RENZI, Lorenzo. (1989). Two types of clitics in Natural Languages. Rivista di Linguistica $1: 2$, p. $355-372$.

RITTER, E. (1995). On the syntactic category oh pronouns and agreement. Natural Language and Linguistic Theory 13. Plumer Academic Publisers: Nitherlands. p. 405-443.

RIZZI, L. (1978). A restructuring rule in italian syntax. In. Recent Transformational Studies in European Languages, ed. S. J. Keyser, 113-58. Cambridge, Mass: MIT Press.

(1982). Issues in italian syntax. Dordrecht: Foris.

ROCHA LIMA, C. H. da. Gramática Normativa da Língua Portuguesa. 46a ed. Rio de Janeiro: José Olímpio Editora, 2007. 
RODRIGUES, Ayron. (2006). Línguas brasileiras: para o conhecimento das línguas indígenas. São Paulo: Edições Loyola.

(1996). As línguas gerais sul-americanas. PAPIA 2(4), 6-18.

SALLES, Vicente. (2004). O Negro na Formação da sociedade paraense. Belém: PakaTatu.

(2005[1971]). O Negro no Pará: sob o regime da escravidão. $3^{\text {a }}$. ed. Belém:

IAP.

SCHER, Ana Paula. (1996). As construções com dois complementos no inglês e no português do Brasil: um estudo sintático comparativo. Dissertação de Mestrado, Universidade de Campinas.

SELKIRK, E. (1980). The role of prosodic categories in English word stress. Linguistic Inquiry $\mathrm{n}^{0} 11$.

(1984). Phonology and syntax: the relation between sound and structure. Cambridge: The M. I. T Press.

SPINA, Segismundo (org.). (2008). História da Língua Portuguesa. Cotia, SP: Ateliê Editorial.

SPORTICHE, Dominique. (1993). Clitics constructions, J. Rooryck \& L. Zaring (eds.) Phrase structure and the lexicon, Dordrecht: Kluwer Academic Publishers.

TARALLO, F. (1996a). Sobre a alegada origem crioula do português brasileiro: mudanças sintáticas aleatórias. In ROBERTS, I \& KATO, M. (Orgs.) O Português Brasileiro: uma viagem diacrônica: homenagem a Fernando Tarallo,. Campinas, SP: Editora da UNICAMP, p. 35-68.

(1996b). Diagnosticando uma gramática brasileira: o português d'aquém e d'além-mar ao final do século XIX. In: ROBERTS, I. \& MATO, M. (Orgs). O Português Brasileiro: uma viagem diacrônica: homenagem a Fernando Tarallo. Campinas, SP: Editora da UNICAMP, p. 69-106.

TEYSSIER, Paul. (2004 [2001]). História da Língua portuguesa. Martins Fontes: São Paulo. THOMASON, Sarah G. \& KAUFMAN, Terrence. (1988). Language Contact, Creolization, and Genetic Linguistics. Berkeley: University of California Press.

TORRES MORAIS, Maria Aparecida; BERLINCK, Rosane de A. (2006) A caracterização do objeto indireto no português: aspectos sincrônicos e diacrônicos In: LOBO, Tânia et al. (eds.) Novos Dados, Novas Análises. Volume.VI. Tomo I. Salvador: EDUFBA. p. 73-106.

BERLINCK, Rosane A. (2007). "Eu disse pra ele" ou "Disse-lhe a ele": a expressão do dativo nas variedades brasileira e europeia do português. In CASTILHO, A. T. et alii (Org.) Descrição, História e Aquisição do Português Brasileiro. São Paulo: Fapesp, Campinas: Pontes Editores. p. 61 a 83.

TRACUATEUA. In: WIKIPÉDIA, a enciclopédia livre. Flórida: Wikimedia Foundation, 2014. Disponível em: 〈http://pt.wikipedia.org/w/index.php?title=Tracuateua\&oldid=38436924>. Acesso em: 9 jul. 2014.

URIAGEREKA, J. (1992). Issues on clitic placement in Western Romance. University of Maryland, mimeo.

(1995). Aspects of the syntax of clític placement in western romance. Linguistic Inquiry 26: 79-123. 
VITRAL, Lorenzo. (1996). A forma cê e a noção de gramaticalização. In: Revista Estudos da Linguagem . Belo Horizonte, 4 (1):115-124.

ZWICKY, Arnold. (1977). On clitics. Bloomington: Indiana University Linguistics Club. 
A NEXOS 


\section{Anexo 1}

Na Babel brasileira, português é segunda língua

Folha de São Paulo (07.07.2009, por Flávio Martin e Vitor Moreno)

\section{Anexo 2}

Decreto $\mathrm{n}^{\mathrm{o}} 7.387$, de 10.12.2010.

\section{Anexo 3}

Relatório Grupo de Trabalho da Diversidade Linguística do Brasil (GTDL). 